\title{
RE-PRESENTACIONES FOTOGRÁFICAS DEL GAUCHO GIL
}

\section{LAS IMÁGENES COMO PRODUCTORAS DE SENTIDOS Y FORMAS DE ARTICULACIÓN DE LA CULTURA POPULAR - MASIVA}

\section{Trabajo de Tesis realizado como requisito para optar por el título de DOCTORA EN COMUNICACIÓN}

\author{
Autora: Cleopatra Barrios Cristaldo
}

Directora: Mariana Giordano - Co-directora: Alejandra Cebrelli 


\section{Dedicatoria}

Este trabajo va dedicado a mis padres Antonia y Abel, por el aliento, el acompañamiento y el amor incondicional

A las memorias con payé y a la cosmovisión mágico-religiosa del Nordeste argentino, por su permanente latencia, más allá de los tiempos

Al Gauchito, su pueblo devoto y su mundo iconográfico agigantado, por darse a ver y ser parte activo de este sueño 


\section{Agradecimientos}

Agradezco especialmente a mis directoras Mariana Giordano y Alejandra Cebrelli, por las lecturas puntillosas, la paciencia y la generosidad infinita que sólo es virtud de los grandes maestros

A Eduardo Longoni, Estela Izuel, Marcos López, Juan Pablo Faccioli y Guillermo Rusconi, por sus imágenes inteligentes, motivadoras, pensativas; en especial a Juan y Guillermo por los caminos del

Gauchito compartidos

A mis amigxs, compañerxs del Doctorado y del Núcleo de Estudios y Documentación de la Imagen del IIGHI - CONICET/UNNE, por los momentos de complicidad y la aventura de des-aprender y reír juntos

A la Facultad de Periodismo y Comunicación Social de la Universidad Nacional de La Plata y a quienes conforman el equipo de Posgrado, en especial a los profesionales que llevan adelante el

Doctorado en Comunicación Social; gracias por la reflexibilidad, la amabilidad y la entrega

Al Consejo Nacional de Investigaciones Científicas y Técnicas de la Argentina, por el otorgamiento de la beca de Posgrado que hizo posible este trayecto de formación

A la Universidad Nacional del Nordeste, mi primer espacio de formación académica, y donde actualmente desempeño tareas de investigación, extensión y docencia; en especial a los compañerxs de cátedras y de proyectos colectivos que, sin lugar a dudas, tuvieron mucho que ver con la 
RESUMEN

Esta tesis analiza las re-presentaciones fotográficas del Gaucho Gil como registro, expresión y recreación de las prácticas socio-culturales vinculadas a la figura popular, mediante la puesta en relación las dimensiones documentales, artísticas y performativas que interactúan en la producción fotográfica. Se parte del abordaje de una serie de fotografías tomadas en la festividad del Gaucho Gil que se desarrolla en la ciudad de Mercedes, provincia de Corrientes, y otras recreaciones fotográficas de la iconografía del santo popular producidas entre 1999 y 2013 por los fotógrafos argentinos Juan Pablo Faccioli, Guillermo Rusconi, Eduardo Longoni, Estela Izuel y Marcos López. El corpus central dialoga con fotos de álbumes familiares otorgadas por informantes durante un trabajo de campo realizado en Mercedes, Corrientes, como así también con fotografías históricas de un relevamiento de archivos realizado entre 2009 y 2012; conversaciones con los fotógrafos, notas de observación de actos fotográficos realizados en la propia festividad del Gaucho Gil y otras textualidades relacionadas con el fin de dar cuenta del espesor temporal de las imágenes. Los objetivos generales apuntan a (1) analizar los modos en que la producción, circulación y consumo de re-presentaciones fotográficas del Gaucho Gil actúan en la configuración, re-creación y resignificación de la festividad del santo popular y de las representaciones de la religiosidad correntina; así como (2) indagar en la configuración de las re-presentaciones fotográficas del Gaucho Gil como espacios de articulación de la cultura popular-masiva; y reflexionar sobre su participación en la construcción de memorias e identidades diversas.

\section{PALABRAS CLAVE:}

FOTOGRAFÍA, RELIGIOSIDAD, GAUCHO GIL, PRODUCCIÓN, CIRCULACIÓN, CONSUMO

Aclaración acerca de los derechos de autor y reproducción de imágenes.

Las imágenes que componen esta tesis están protegidas por derechos de autor en el marco de la Ley de Propiedad Intelectual. En este texto se incluyen con fines académicos y de investigación y no con fines comerciales. No se permite la reproducción parcial o total de las mismas por cualquier medio sin tramitar permiso previo de los autores. 


\section{INDICE}

Prefacio. Trayectorias y motivaciones de indagación $\quad 8$

Introducción. Configuración temática, itinerarios del texto, ingresos de lectura $\quad 14$

\section{PARTE: DEL PROBLEMA AL ENFOQUE DE ANÁLISIS}

\section{CAPÍTULO 1:}

Debates y posiciones teórico-metodológicas: la re-presentación fotográfica

1. La RF como huella, documento y artefacto cultural 31

2. La RF como dispositivo entre miradas y relaciones de saber/poder 37

3. La RF como imagen anacrónica, actos de imagen y modo de presencia 42

4. La RF como actante con doble poder o potencia per-formativa 48

5. La RF como imagen-acto e imagen-identidad 51

CAPÍTULO 2:

Debates y posiciones teórico-metodológicas: fotografía, identidades y religiosidad

1. Las identidades y la RF del Gaucho Gil: relaciones, anclajes, tensiones 58

2. Pensar imágenes en el "ámbito religioso” y más allá: discusiones nominales 63

3. Estudios sobre religiosidad, comunicación y cultura visual: debates compartidos 67

4. Lo visual entre prácticas de sacralización en un campo religioso heterogeneizado 74

5. Hacia un enfoque de análisis relacional, transdisciplinar y contrastivo 77

6. Las herramientas de abordaje: métodos, instrumentos y técnicas 82

\section{2a PARTE: DEL CASO A LAS APROPIACIONES FOTOGRÁFICAS}

\section{CAPÍTULO 3:}

El Gauchito iconográfico y fotogénico: ingresos al caso y a las imágenes

1. Memorias del Gaucho Gil: una devoción expandida a la vera del camino 89

2. Del Curuzú Gil al Gaucho Gil: el espesor histórico del ícono popular-masivo 93

3. Símbolos de la formación de la nación en la imagen del "santo" popular 99

4. El Gauchito entre los difuntos "santificados" massmediáticos de los 90' 104 
5. Una imagen y múltiples identidades en un campo religioso y comunicacional diversificado

6. La construcción de una iconografía móvil y performática

CAPITULO 4:

Foto, memoria y religiosidad correntina. La configuración de miradas 129 hegemónicas

1. Políticas visuales y prácticas de captura y archivo de fotografías

1.a)- Procedimientos de ordenación/clasificación de miradas y memorias

1.b)- La foto y el archivo, dispositivos productores de miradas y memorias

2. Escenas de la religiosidad correntina in-dignas para fotografiar y resguardar

2. a)- El mapeo de los acervos fotográficos: de la abundancia a la escasez

2. b)- Las fotos de la religiosidad correntina admitidas entre las vistas del progreso

3. Visibilización de lo popular en tiempos de la cultura massmediática y digital

4. Notas finales sobre la des-estabilización de representaciones la religiosidad correntina

CAPITULO 5:

\section{Fotografías del Gaucho Gil. Descentramientos de las miradas en cinco 166 producciones}

1. Estructuras de composición de un paradigma de representación hegemónico

2. De la toma descriptiva-estática al retrato en acción y la captura de la atmósfera cultural

3. De la exaltación de la fe en los cuerpos a la focalización en capas de la memoria

4. Del reino del índex a la fuerza de la simbolización en el artificio

5. La estampa del Gauchito en el juego de las citas y apropiaciones

5.a)- Entre el Martin Fierro y la encarnación del Gauchito en la foto de Juan Pablo Faccioli

5.b)- El retorno del gaucho malevo en la fotografía de Marcos López

6. Notas finales sobre descentramientos de miradas y reconfiguraciones representacionales

CAPITULO 6:

Imágenes melodramáticas y proyecciones identitarias en el acto fotográfico

1. El melodrama fotográfico de la cultura popular-masiva 204

2. Las matrices históricas-culturales de las formas de sentimiento 206

2.a)-La configuración emotiva de las representaciones artísticas-comunicativas $\quad 206$ 
3. El Gauchito melodramático en la práctica de fotografiar de Faccioli y Rusconi 214

4. Formas de ver y dar(se) a ver desde la poética melodramática 217

5. El acto fotográfico como lugar de proyecciones identitarias 221

6. Notas finales sobre fotografía, melodrama, religiosidad y adscripciones identitarias 227

A MODO DE CONCLUSIÓN

Re-presentación, performatividad y re-politización de la mirada

REFERENCIAS BIBLIOGRÁFICAS

ANEXO

Conversaciones con los fotógrafos Juan Pablo Faccioli y Guillermo Rusconi 


\begin{abstract}
Las ciencias sociales se alimentan del mundo, ese es el material de su existencia. El observador, aquel que lo analiza, está inmerso en los problemas de ese mundo. Su sensibilidad histórica funciona por tanto como estímulo intelectual.
\end{abstract}

Renato Ortiz, Taquigrafiando lo social

Las inquietudes que motivaron esta investigación sobre las re-presentaciones fotográficas del Gaucho Gil surgen de una mezcla de fascinación y desagrado experimentada como cronista de festividades religiosas de Corrientes, provincia del Nordeste argentino ${ }^{1}$.

En primer lugar hablo de fascinación porque al acompañar, desde la cobertura periodística de prácticas religiosas, las búsquedas de "lo fotografiable" de compañeros fotorreporteros observé cómo la fotografía interpretada desde del acto fotográfico se configuraba como un espacio complejo de intersecciones. Ante mi mirada, la imagen fotográfica empezaba a tomar forma de una densa trama que condensa mucho más de lo que a simple vista nos puede ofrecer la visibilidad primera de su reproducción material en las páginas de un diario o en la pantalla. Es decir, refiero a un estado de fascinación al avizorar, desde un sentido de la experiencia práctica y vivencial del acto fotográfico, cómo distintos niveles de relación, atravesados por intereses diversos, son las que definen o moldean una imagen y no otra de esas prácticas.

Esta mirada de "lo fotográfico" me convocó a re-dimensionar el juicio simplista que mantenía sobre el carácter comunicacional de la fotografía en estos ámbitos. Entonces, empecé a entenderla, más allá de su función de ilustración, registro o documentación de un acontecimiento, como un espacio de encuentros de miradas de fotógrafos y fotografiados,

\footnotetext{
${ }^{1}$ Me desempeñé como redactora y cronista en diarios digitales y agencias de noticias y fundamentalmente desde el diario El Libertador de la provincia de Corrientes de 2005 a 2011, realicé la cobertura de festividades religiosas. En estos trayectos se incluyeron crónicas sobre prácticas socio-culturales vinculadas a la festividad del Gaucho Gil (Mercedes), la Virgen de Itatí (Itatí), la Inmaculada Concepción (Concepción), la Pilarcita (Concepción), San Baltazar (Concepción y Corrientes Capital), Sana Ana (Santa Ana de los Guácaras), la Cruz de los Milagros, Virgen de la Merced y San Juan (Corrientes Capital), entre otros. La enumeración de algunos casos responde a dar cuenta de la imbricación de cultos populares y oficiales que caracteriza las devociones de esta provincia, siendo la festividad del Gaucho Gil una de las de mayor crecimiento, en cuanto la cantidad de fieles, en los últimos años, la más compleja, heterogénea e iconográfica, características que la han llevado a trascender las fronteras provinciales. Por el interés en este entramado, focalizo este análisis en las imágenes de esta festividad y la figura del Gaucho Gil.
} 
atravesado por posiciones bien marcadas, formas de disposición de los cuerpos y los gestos, tendencias estéticas e intereses económicos e ideológicos particulares, locales y globales ${ }^{2}$.

La idea de la fotografía concebida como lugar de encuentros e intersecciones, vinculado a prácticas discursivas y formaciones históricas específicas, me llevó a re-significar también la idea de productor de la fotografía. Comprendí que no podía atribuirle ese rol sólo al fotógrafo o al medio gráfico ya que también los mismos fotografiados y las condiciones socio temporales específicas intervienen, participan activamente de esa producción de sentido que vehiculiza la fotografía ${ }^{3}$. Ello complejizó aún más mi reflexión sobre esta configuración temática y su problematización abrió preguntas en torno a los modos en que fotógrafos, medios, fotografiados, circunstancias y temporalidades diversas construyen una imagen de sí y cristalizan en la materia fotográfica una visión de sus prácticas sociales para ser reconocidos y recordados de determinada manera y no de otra.

A raíz de los primeros recorridos realizados en la indagación de representaciones fotográficas, gracias a una beca otorgada por la Universidad Nacional del Nordeste primero y por el Consejo Nacional de Investigaciones Científicas y Técnicas después ${ }^{4}$, la interrogación al y en el campo de la fotografía de rituales religiosos buscó analizar cómo funciona en las imágenes la re-creación de estéticas e ideologías dominantes y/o la exploración de formas emergentes. Esta preocupación estuvo influenciada por los planteos de los estudios culturales ingleses, en cuyo marco resultó central la lectura de Raymond Williams sobre la hegemonía y las formas dominantes, residuales y emergentes de la cultura; así como los estudios sobre las representaciones y las articulaciones de Stuart Hall. Dicha línea de investigación marca buena parte de los senderos abiertos por esta tesis que, principalmente, buscan entender la cuestión simbólica de estas re-presentaciones como parte activa de la configuración de las prácticas sociales y culturales. El trabajo además se nutre de las discusiones entabladas por intelectuales de los estudios visuales y los estudios de comunicación en Latinoamérica, entre otros extensos debates desarrollados en el marco del Doctorado en Comunicación en la FPyCS de la UNLP.

\footnotetext{
${ }^{2}$ Esto lleva a indagar toda una serie de nociones que presenta la tesis en los capítulos sobre debates y posiciones teórico- metodológicos.

${ }^{3}$ Esta lectura permitió abrir algunas preguntas sobre rol de los representados en las instancias decisivas de la construcción de la re-presentación fotográfica.

${ }^{4}$ En 2009, a través de una beca otorgada por la Secretaría de Ciencia y Técnica de la UNNE inicié el trabajo Representaciones sociales, prácticas de religiosidad popular e imagen visual. Fotografias de las procesiones de Corrientes capital, Santa Ana de los Guácaras y Concepción; luego con el proyecto Representaciones de prácticas religiosas en Corrientes. La fotografía como registro y expresión de la memoria colectiva obtuve la beca doctoral de CONICET, centrando el análisis en conjuntos fotográficos de las festividades de la Virgen de Itatí y el Gaucho Gil.
} 
Por otra parte, debo señalar que desde actos fotográficos concretos, sobre todo aquellos desarrollados en 2010 y 2011 en la festividad del Gaucho Gil en Mercedes Corrientes donde seguí la trayectoria de dos fotógrafos y sus prácticas ${ }^{5}$, observé que una mayor implicancia de los fotógrafos con lo fotografiado, un contacto más prolongado y con predisposición de apertura sensible a la demanda propia del acontecimiento, les posibilitaba plantear mayores diálogos y asumir mayores riesgos en la construcción conceptual de la fotografía. En otras palabras, advertí que estas condiciones posibilitaban construir una imagen a partir de una red de relaciones que expresada en la imagen es capaz de dar cuenta de visiones alternativas y/o descentradas de las posiciones de captura dominantes. Este proceso de acercamiento marcaba la diferencia en comparación con aquellas instancias en que, arrebatados y restringidos por la lógica de la inmediatez, los fotógrafos se conectaban de manera fugaz con su referente y se limitaban a conseguir la imagen que testimonie la masividad, el desborde, los estereotipos folclorizantes, respondiendo a los valores-noticia e intereses mercantiles mediáticos establecidos.

Así, desde una perspectiva nutrida por observaciones en campo, lecturas y conversaciones con los compañeros fotoperiodistas, entendí que en ciertas situaciones y en la mirada menos implicada delinea la confección fotográfica el concepto que se ajusta a la lógica del mercado y a los regímenes visuales dominantes. Un concepto que define como "vendible" aquellos fragmentos que responden a los criterios de noticiabilidad, de espectáculo, entretenimiento, magnitud, emoción, como receta segura. Mientras que la mirada implicada posibilitaba dejar que la fotografía suceda y madure en un proceso de mayor intercambio. Estas cuestiones relativas al acto fotográfico, instancias de captura, relaciones, condiciones y factores que intervienen en la producción de la imagen, son retomadas particularmente en este texto.

Ahora bien, ¿a qué me refiero con el desagrado? El sentimiento de disgusto surgió en el plano de la valoración de las imágenes a la hora de su "puesta en página" en los cierres de las ediciones de las reacciones de los diarios provinciales en general y de los que yo participaba en particular. Observé que las fotografías que respondían a propuestas más audaces y rupturistas, tanto en materia de forma como de contenido, no siempre eran tenidas en cuenta por los periodistas/editores para su publicación. Vi una y otra vez cómo eran favorecidas las fotografías de corte más costumbrista, tradicional o de estéticas con eficacia probada en el campo de la circulación mediática, confinando a las visiones "otras" que no

\footnotetext{
${ }^{5}$ Algunas notas de esta observación de los actos fotográficos se vuelcan en el Capítulo 6.
} 
cumplieran con esos "condimentos" al ocultamiento del archivo. Esto sucedía de manera prácticamente asidua con las publicaciones de los tres diarios tradicionales de circulación provincial $^{6}$ en los que centré mi reflexión desde los inicios de mi tarea como reportera hasta el desarrollo de esta tesis.

En el marco de la observación de estos sistemas de selección/ clasificación/ edición de la imagen, evidencié que optar por una imagen que recupera formas de estructuración, composición, codificación altamente reconocidas por el público era apostar al efecto pragmático inmediato en el público, a la eficacia comunicativa del registro que consigue que el lector identifique el acontecimiento que se narra, más allá de lo que esa imagen pueda aportar de novedoso, enriquecedor o reflexivo. De allí, empecé a preguntarme en qué medida la apuesta permanente a la publicación de determinadas imágenes y no de otras estaba o no actualizando valores dominantes sobre la cultura ritual correntina. Entonces germinó la inquietud por el contraste de estas fotos actuales con las históricas. También me cuestionaba cómo debería ser una imagen que asegure reconocimiento pero sin relegar por ello la información comprometida, innovadora, contestataria o reflexiva que pueda otorgarnos una fotografía sobre y en relación a determinados procesos o prácticas socio-culturales; y en el seno de estas tensiones: cómo se tejen las construcciones visuales hegemónicas y descentradas del orden establecido de lo visible.

Asimismo abonó esta preocupación la propuesta de un diario nuevo de tirada provincial $^{7}$, que venía a plantear desde sus inicios una valoración distinta del quehacer fotográfico. Entre otras cuestiones, instaló una doble central semanal destinada al foto reportaje a cargo por completo del criterio de los fotorreporteros, quienes vieron en ese espacio la posibilidad de dar visibilidad a búsquedas no siempre tenidas en cuenta por los editores hasta el momento; también se incluyó la decisión del fotógrafo en la elección de la foto de tapa ${ }^{8}$. Esta tendencia apareció en este contexto provincial como un leve y retardado eco de las renovadoras formulaciones de diseño y concepto del periodismo gráfico nacional que sucedió tiempo antes y que le otorgó lugar privilegiado a la imagen en la construcción del acontecimiento, sobre todo con el caso Página/12. Este proceso de revalorización de la imagen daba que hablar en los cafés que particularmente compartía con los fotoperiodistas entre ellos Juan Pablo Faccioli y Guillermo Rusconi cuyo trabajo aquí abordo- cuando

\footnotetext{
${ }^{6}$ Diarios Época (1973-sigue), El Litoral (1960-sigue) y El Libertador (1999-sigue).

${ }^{7}$ Diario La República de Corrientes (2005- sigue)

${ }^{8}$ Cabe señalar en este sentido que las redacciones de diarios tradicionales del Nordeste no contemplan la figura del editor fotográfico como sí los hay en las grillas de medios de otras provincias y la Capital Federal.
} 
iniciaba el trabajo de observación más detenida de los actos fotográficos desde las festividades con el objetivo de volcarlo en esta tesis.

Si bien el diario de ideas renovadoras en torno al campo del fotoperiodismo, en medio de una serie de crisis, a poco de cuatro años de circulación, dio marcha atrás con todos estos planteos en torno a la fotografía, el debate y la necesidad de producir y poner a circular representaciones fotográficas "más jugadas" desde lo compositivo y conceptual se instaló en la primera década del siglo XXI. Esta inquietud se vio motorizada sobre todo por el auge de páginas web dedicadas a ensayos y reportajes fotográficos, redes sociales de fotografía que se han vuelto muy populares y otros espacios asociados a las producciones artísticas que dieron lugar a la exhibición de fotografías provenientes del campo del reportaje periodístico, la documentación y la experimentación artística.

En este contexto, la referencia a las devociones populares correntinas se constituyó en una constante que atravesó la configuración temática de las producciones fotográficas provinciales y también de aquellas nacionales que buscaban incorporar marcas identitarias del Nordeste o de la cultura popular nacional en sus obras. Particularmente, la festividad y la figura del Gaucho Gil ganaron predilección en los reportajes y las producciones artísticas de los años 2000. Este interés se focalizó en exaltar la emotividad, la teatralidad, la densa iconicidad de las prácticas religiosas, así como la heterogeneidad propia de la iconografía del santo popular correntino; y registrar aspectos de los altares y manifestaciones devocionales masivas que comenzaron a concebirse desde el mundo del arte como verdaderas "instalaciones" y "performances" producto de la creatividad popular".

Se constituyó ante mis ojos un campo de producción de fotografías que mezclando caracteres documentales, foto-periodísticos y artísticos concibieron imágenes del Gaucho Gil que no sólo siguen lineamientos de adhesión a los cánones de representación históricamente establecidos, sino también plantearon miradas descentradas: incluyendo formas de resistencia, rechazo, rupturas, diferencia. Estas propuestas en la medida que fueron reproduciendo aspectos de lo representado también apostaron a formas creativas de significar los objetos o prácticas a las que aludían, re-significándolos en su tránsito por diversas instancias de circulación.

\footnotetext{
${ }^{9}$ Se puede mencionar la muestra "Altares populares: el Gaucho Gil”, que incluyó pinturas, videos y fotografías de varios artistas expuesto en 2004 en Tono Rojo, Recoleta, Buenos Aires. En Corrientes en 2006 se realizó un salón especial en el Museo de Bellas Artes denominado "Antonio Gil con ojos correntinos". Luego se pueden contabilizar alrededor de cinco largometrajes entre ficción y documental argentinos sobre esta figura, y proyectos artísticos individuales que han recorrido el mundo: imágenes e instalaciones de Daniel Barreto, Sergio Gravier, Marcos López, Estela Izuel, entre otros. Ello sin contar las múltiples referencias de la prensa gráfica y la TV.
} 
En el marco de estas trayectorias de experiencia, observaciones y primeras lecturas surgió la necesidad de superar las nociones del sentido común, de desnaturalizar las prácticas, los rituales del quehacer periodístico, los esquemas de concepción del mundo fotográfico ligado a lo religioso; en definitiva, de "desfamiliarizar lo familiar" como nos enseñó la sociología ${ }^{10}$, insistiendo con las preguntas sobre las distintas dimensiones que construyen las re-presentaciones fotográficas del Gaucho Gil y los modos en que éstas transitan y son valoradas en campos de fronteras difusas: el fotoperiodismo, la documentación, el arte ${ }^{11}$. En esta línea, esta investigación parte de una conjetura inicial: la concepción de las fotografías del Gaucho Gil como formas de registro, expresión y espacios no sólo de reproducción sino también de re-creación, re-significación de la propia festividad, de la figura del santo popular y de las representaciones sociales de la religiosidad correntina; reflexión que intenta abrirse paso en un contexto más amplio de discusiones teórico-conceptuales y operativas sobre el abordaje de la producción, circulación, consumo y reproducción de la fotografía contemporánea en relación a la cultura popular-masiva, las prácticas sociales y discursivas y la configuración de memorias e identidades.

\footnotetext{
${ }^{10}$ Ver Bauman (1994)

${ }^{11} \mathrm{Si}$ bien las inquietudes surgen en el plano del ejercicio periodístico, las mismas cobran forma de problema de investigación con la acreditación de becas y proyectos en el marco del Instituto de Investigaciones Geohistóricas CONICET/UNNE y se nutren también de las lecturas desarrolladas como docente universitaria (fui docente en las cátedras Teoría de la Comunicación I, Estética e Historia del Arte y Lenguaje Visual; actualmente dicto clases en las asignaturas Comunicación y Cultura, y Semiótica en la Facultad Artes de la UNNE).
} 
Iniciar la "costura" de este texto implica varios desafíos. Uno de ellos es realizar el punto de hilván. Es decir, empezar a "hilvanar las ideas" del trabajo intelectual como sugiere Renato Ortiz, en tanto gesto que relacionará provisoriamente dos telas: los planteos particulares en torno a unos datos y materiales que hacen al caso de abordaje y los debates más amplios que configuran el campo de discusión al que este entretejido de reflexiones se orienta con el fin aportar su matiz, su textura, su punto de vista.

En lo que hace a las concepciones de la fotografía, vale señalar que en este análisis se utiliza el término re-presentación fotográfica para hacer alusión a la doble dimensión de representación-presentación de la fotografía; es decir atendiendo tanto a los sentidos sociales e ideológicos que ella entrama como su especificidad material expresiva visual como "forma de presencia" con capacidad de interpelación al espectador (Marin, 2009; Bredekamp, 2010; Mitchell, 2003). Esa doble dimensión de lo fotográfico es explorada, a su vez, a partir de las reflexiones interdisciplinarias en torno a los procesos de producción, circulación, consumo y reproducción fotográfica que, desde enfoques diversos, reivindicaron el lugar central de la imagen fotográfica en la mediación de la experiencia social; y por lo tanto también construcción de memorias, imaginarios y la adscripción de identidades.

De hecho, actualmente la sola consideración de la fotografía como uno de los modos de representación indicial-iconográfica y simbólica más difundida y electa por mayoría de las personas para percibirse, construirse una imagen de sí y darse a ver, justifica redoblar esfuerzos e interrogantes acerca de las estrategias de puesta en discurso que la foto entrama y los intereses ideológicos que pone a circular en coyunturas sociales-culturales específicas (Barrios, 2014).

En este sentido, en el contexto latinoamericano y particularmente el argentino, donde 
hacia fines del siglo XX y principios del XXI se reinstaló el debate acerca de las formas de construir pertenencias- ello también estimulado por diferentes situaciones de crisis y procesos de transformación socio-cultural y comunicacional ${ }^{12}$, , resulta relevante volver la mirada hacia la imagen fotográfica entendiéndola como "artefacto", "dispositivo" semiótico comunicativo no sólo de registro sino de producción de la visualidad y la in-visibilidad de esas "identidades en pugna" (Grimson, 2004).

Haciendo foco en este proceso, este trabajo analiza fotografías que se gestan en, desde y sobre "prácticas religiosas" o "prácticas de sacralización"13 vinculadas a la festividad central y a la figura del "santo" popular correntino Gaucho Antonio Gil. En términos generales, la tesis busca advertir los modos en que estas fotografías desde sus instancias de producción, circulación y consumo actúan en la configuración, re-creación y re-significación de las prácticas socio culturales vinculadas a la festividad del Gaucho Gil y de las representaciones de la religiosidad correntina; e indagar en qué medida estas representaciones fotográficas se configuran como espacios de articulación de la cultura popular y masiva; así como de construcción de memorias e identidades.

Como punto de partida, los objetivos mencionados presuponen una configuración temática y problemática compleja, y más aún teniendo en cuenta la heterogeneidad de los textos y materiales que se entrelazan en la construcción del objeto de estudio. Un objeto que no nos viene dado sino que se construye en la intersección de nuestra mirada, las lecturas y las experiencias que nos atraviesan y que delinean nuestro posicionamiento analítico.

En este sentido, con el fin de facilitar la lectura y comprensión del texto, se advierte en los subtítulos que siguen algunos criterios que guiaron las decisiones de focalización, anclajes de lectura y observación de prácticas socio-culturales específicas; búsqueda, relevamiento de antecedentes y selección de materiales; todas operaciones que han sido cruciales en la delimitación, justificación y desarrollo de la propuesta analítica; luego se expone un orden posible de ingresos de lectura a la presente escritura, para señalar finalmente- algunas notas sobre los alcances y limitaciones de esta investigación.

\footnotetext{
${ }^{12}$ Hablamos entre otros procesos socio-culturales que han marcado la historia argentina de: la dictadura miliar de los 70' y el despertar democrático en los 80'; la política neoliberal de los 90 y el crecimiento de la globalización; la profunda crisis socio-económica de 2000; las luchas, tensiones y proyectos políticos, económicos y culturales puestos en juego en la etapa de superación de la crisis y reconstrucción social.

${ }_{13}$ Algunas consideraciones teóricas respecto al pasaje de la consideración de las prácticas religiosas más bien como prácticas de sacralización se discuten en el Capítulo 2, siguiendo la propuesta de Eloisa Martin (2007).
} 


\section{Focalización, anclajes, fundamentación}

Esta tesis se focaliza en el análisis de prácticas de fotografiar y re-presentar a través de la imagen manifestaciones devocionales, por considerar que estas prácticas y representaciones fotográficas son lugares de convivencia de significantes, significados, temporalidades diversos donde, a su vez, se articula la relación entre los actores sociales, las formaciones discursivas, las operaciones de textualización y las representaciones sociales productoras de memorias y adscripciones identitarias (Didi Huberman, 2006, Cebrelli y Arancibia, 2005).

Como anclaje geográfico de punto de partida se eligió Corrientes por configurarse como una de las provincias de mayor tradición católica en la Argentina y, a la vez, con una gran presencia de cultos populares, cuya construcción identitaria se teje -entre otros aspectosen las "prácticas religiosas" por conformación heterogéneas ${ }^{14}$. Justamente, la heterogeniedad y la densidad histórica de estas prácticas encuentran una de sus mayores expresiones en la festividad central del Gaucho Gil que se celebra cada 8 de enero en Corrientes, y en la reproducción de devociones en torno a la figura de Gil en distintos puntos del país. De allí la focalización del abordaje en las imágenes de esta conmemoración.

La celebración central en honor al "santo" popular tiene lugar a la vera de la Ruta Nacional $\mathrm{N}^{\mathrm{o}} 123$ en la ciudad de Mercedes, provincia de Corrientes, ubicada en el Nordeste de la República Argentina. Banderas y cintas rojas, símbolos religiosos diversos y comercio marcan el sitio donde muriera degollado en manos de la policía el gaucho Antonio Mamerto Gil Núñez un 8 de enero hace más de 100 años. Según cuenta la leyenda, Gil era perseguido por desertar del ejército y robar a viajeros y terratenientes. Un supuesto milagro que habría realizado poco antes de morir (el de salvarle la vida al hijo de su asesino) y por repartir su botín entre los más necesitados dio origen a la leyenda de gaucho milagroso y justiciero. La devoción en torno a este "santo" fue extendida a todo el país hacia la década del 90 y se

\footnotetext{
${ }^{14}$ Según los últimos informes del CEIL-CONICET (2008) y la Universidad Católica Argentina (2013) la región NEA, a la que pertenece Corrientes, presenta entre un 84 y un 79 por ciento de adeptos a la religión católica, respectivamente según ambas mediciones. En tanto, entre las adscripciones a otras religiones (Evangelistas, pentecostales, mormones, testigos de Jehová y otras), en la región se contabiliza entre un 10 y 13 por ciento. Sin embargo, hay que señalar, siguiendo a Frigerio (2007), que las reivindicaciones de estas identidades sociales dicen poco de las identidades personales y las creencias de las personas que entretejen demandas y prácticas mucho más complejas. Tal es el caso de los cultos populares que, particularmente en Corrientes, entremezclan ritos con influencias diversas, devoción a santos católicos y no católicos, muchos ligados a veneraciones de raigambre guaraní. Incluso la provincia posee un santoral popular propio, amplio y heterogéneo (Salas, 2008; Bondar, 2013). En este marco, en esta provincia, se puede rastrear la leyenda viva de al menos sesenta "gauchillos alzados", muchos hoy recordados como figuras milagrosas, entre ellos el Gaucho Gil (Piñeyro, 2005).
} 
visibiliza a través de grandes altares y pequeñas ermitas que le construyen los fieles a la vera de las rutas.

Vale señalar que las prácticas devocionales ligadas a esta festividad presentan, a su vez, un alto grado de iconicidad y expresividad que atrae fuertemente la atención de la industria de la comunicación masiva. Ella observa en estos ritos una fuente inagotable de testimonios e historias de vida melodramáticas, visualmente impactantes, útiles para alimentar sus productos y atender las demandas de venta y consumo. Es así que, hacia la fines década del 90' y comienzos de los años 2000, fotógrafos y audiovisualistas profesionales y aficionados del país, atendiendo a esa demanda, aportaron a la proliferación de producciones sobre esta manifestación devocional, colaborando con su reproducción; así como a la apropiación y re-significación de la figura del "santo" popular (gaucho Antonio Gil) en diversos ámbitos de producción documental, periodística y artística regional y nacional.

De estos procesos de simbolización surge la inquietud de indagar sobre los modos en que las fotos producen la re-creación de las "prácticas religiosas" o "prácticas de sacralización" vinculadas a la imagen del Gaucho Gil; siendo esta producción un ámbito donde interactúa tanto la dimensión representacional de la imagen como la del acto/ práctica de fotografiar, lo que a la vez exige a esta reflexión el hilván tanto de las teorías de la representación fotográfica, como de las prácticas sociales.

También se seleccionaron fotografías de esta festividad porque se la considera una de las de mayor convocatoria en la provincia de Corrientes ${ }^{15}$ y una fuente compleja propulsora de adscripciones identitarias masivas. Asimismo porque esta manifestación se configura como un fenómeno que incluso trasciende la frontera provincial, habilitando a los fotógrafos/artistas visuales a valerse de los signos y las prácticas que reproduce este ritual para componer imágenes que referencian aspectos más amplios de la "religiosidad popular argentina" y no sólo la correntina, y re-significar el símbolo del "gaucho argentino" o las figuraciones de la "santidad" desde la multifacética imagen que representa Antonio Gil. En este marco, entre las "prácticas religiosas" y prácticas extrarreligiosas, estrechamente ligadas a la diversificación de las primeras, y sus re-presentaciones fotográficas se cuelan algunos debates sobre la cultura popular-masiva y la construcción de memorias e identidades en los que también nos detendremos a reflexionar.

\footnotetext{
${ }^{15}$ Entre los años 2010 y 2014 se estimaron entre 250 y 700 mil visitantes en la jornada central de 8 de enero en Mercedes, llegando incluso igualar y hasta a superar, con estas estimaciones la convocatoria de las festividades centrales de la Virgen de Itatí, la patrona de la provincia y una de las advocaciones marianas católicas de mayor popularidad en la Argentina.
} 


\section{Corpus: particularidades, temporalidades, modos y ámbitos de circulación}

A la luz de la complejidad y diversidad de los procesos relacionados al material fotográfico con referencia al Gaucho Gil, en esta tesis se seleccionaron para el abordaje fotografías producidas entre 1999 y 2013 por los fotógrafos Juan Pablo Faccioli, Guillermo Rusconi, Eduardo Longoni, Estela Izuel y Marcos López. Estas imágenes de "autor" -cuyas "identidades" tipológicas ${ }^{16}$ discurren entre el reportaje, el documento y el foto arteconfiguran el corpus central de la indagación. Asimismo ellas se ponen en diálogo con fotos históricas (datan de la década del 70’ y el 80') proporcionadas por entrevistados -fotos de álbumes familiares - durante el trabajo de relevamiento y observación realizada entre 2010 y 2011 en el día de la festividad central, el 8 de enero, así como días previos y posteriores a la conmemoración en la ciudad de Mercedes; y otras puestas a circular por mercedeños y devotos a través de páginas web.

También se toman para el análisis contrastivo fotografías de principios del siglo XX que surgen de relevamientos realizados en archivos fotográficos históricos. En particular prestamos atención a las imágenes recabadas en el Museo Histórico de la Provincia de Corrientes y en el Archivo General de la Nación. Estos materiales, a su vez, se relacionan en el entramado de estas reflexiones con conversaciones con los fotógrafos, otras textualidades circulantes, especialmente iconográficas, y algunas notas de observaciones de actos fotográficos desarrollados en el ámbito de la propia festividad del Gaucho Gil en Mercedes.

La focalización de la investigación en la obra de los cinco fotógrafos antes mencionados responde a las características singulares que presentan sus producciones y que desde nuestra perspectiva representan diferentes vías de visualización del complejo fenómeno de las "prácticas religiosas" populares o "prácticas de sacralización” ligadas al Gaucho Gil. En el caso de Faccioli y Rusconi hablamos de una producción sostenida en el tiempo (20082012) que realizaron ambos fotógrafos a través de miradas compartidas de la festividad mercedeña y que plantean en la continuidad y en su implicación con lo retratado un cambio de miradas en comparación a las coberturas esporádicas realizadas por otros reporteros gráficos. Asimismo la trayectoria de fotografiar de estos fotorreporteros fue seguida a través de una observación participante que realizamos en los años 2010 y 2011, los días 8 de enero.

\footnotetext{
16 Se plantean los términos autor e identidades de los géneros fotográficos entrecomillas porque una de las cuestiones que surge del análisis de la "vida" o la productividad de las imágenes entre las prácticas y los discursos nos lleva a la relativización y la problematización de estos términos, sobre todo teniendo en cuenta que las imágenes abordadas conforman múltiples procesos de apropiaciones y re-significaciones.
} 
En la producción de 2013 de Eduardo Longoni encontramos uno de los primeros ensayos documentales con una clara línea conceptual de valoración de la festividad desde su potencia visual y la expresión e inscripción de la fe en los cuerpos.

Por su parte, Estela Izuel plantea una de las primeras producciones en el país de registro-artístico-documentales realizadas sobre distintos santuarios populares de la Argentina que la llevaron a centrar la mirada en los exvotos, objetos y detalles que configuran la simbología del santuario del Gaucho Gil, desde 1999 en adelante.

Finalmente tomamos algunas obras de Marcos López de su serie Sub-realismo criollo y, en particular, una fotografía de 2008, cuyo género discurre entre la foto instalación y el arte, donde el artista se apropia la figura del gaucho Gil para plantearlo como símbolo de identidad nacional en la configuración de simbologías latinoamericanas ${ }^{17}$.

Sobre los espacios de circulación/mostración, vale decir que estas imágenes (las históricas y las actuales) fueron publicadas en la prensa gráfica impresa, páginas web dedicadas a reportajes fotográficos, en perfiles particulares de fotógrafos desde redes sociales de fotografía, fotolibros y salones exposición regional, nacional e internacional. La mayoría de ellas han sido producidas en el ámbito propio de los ritos que referencian, e incluso aquellas construidas desde estudios fotográficos se han "viralizado" en distintos contextos de un modo tal que han vuelto a re-insertarse en el ámbito de las prácticas devocionales a través de usos y apropiaciones diversos, tales como su reproducción en remeras, objetos e incluso la inscripción en tatuajes, entre otros.

\section{Los fotógrafos y algunos trayectos con la fotografía}

Juan Pablo Faccioli nació en 1983 en Reconquista, Santa Fe y residió en Corrientes hasta 2013 donde se desempeñó como reportero gráfico, actualmente trabaja en la provincia del Chaco. Guillermo Rusconi nació en 1982 en Rosario Santa Fe, residió en Corrientes hasta 2008 y actualmente reside en Buenos Aires donde también se desempeña como reportero gráfico. Ambos han publicado imágenes sobre la festividad del Gaucho Gil en diarios provinciales y nacionales y particularmente fueron elegidos para esta indagación porque entre 2008 y 2012 han emprendido en forma consecutiva búsquedas compartidas de captura y construcción estética de la festividad mencionada, siendo los ensayos resultantes algunas de sus principales producciones también expuestas en muestras.

\footnotetext{
${ }^{17}$ Más detalles sobre la particularidad de estas fotografías de "autor" se abordan del Capítulo 3 al 6.
} 
Por su parte, Eduardo Longoni nació en Buenos Aires en 1959 es editor de fotografía del diario Clarín. Comenzó su actividad como fotógrafo en Agencia de Noticias Argentinas y en 1987 creó su propia agencia de fotografía (EPD/PHOTO). Sus producciones sobre la dictadura militar argentina son las más conocidas a nivel nacional e internacional, las que lo han hecho merecedor de varios premios y distinciones; y en 2013 emprendió el ensayo sobre la figura del Gaucho Gil que forma parte de su último libro "Superficies" junto al fotógrafo Jorge Piccini.

La fotógrafa Estela Izuel nació en La Plata en 1966, es egresada la Facultad de Bellas Artes de la Universidad Nacional de La Plata. A través de un subsidio de la Fundación Antorchas realizó un ensayo sobre santuarios populares entre 1997 y 2000 y de ello surgió un trabajo especial sobre el Gaucho Gil en el santuario en Mercedes en 1999. Desarrolla su actividad fotográfica vinculada a los espacios de exhibición artística, ha recibido varios premios y expuso en salones nacionales e internacionales (entre ellas muestras Praxis International Art Miami; Altar Girls en el Museo de las Américas, Denver, USA, Interfaces La Plata - Corrientes, entre otros).

En tanto, Marcos López, nacido en Santa Fe en 1958, indaga en sus inicios en la fotografía documental, destacándose el retrato. Luego se dedica de lleno a la foto publicitaria y artística, así como el cine. De su obra se destacan "Retratos", "Pop Latino" y "Subrealismo Criollo" (en las últimas dos ha dedicado producciones a la figura del Gaucho Gil). Sus fotografías forman parte de las colecciones del Museo Nacional de Arte Reina Sofía y el Museo de Arte Contemporáneo de Castilla y León en España, la Fundación DarosLatinoamérica en Suiza, Quai Branly, entre otras colecciones públicas y privadas.

\section{Anticipos sobre la perspectiva de análisis}

Teniendo en cuenta las particularidades de los materiales analizados y el interés de indagar sobre la "productividad" de las imágenes y su rol activo en la construcción de lo social como postula Mitchell (2003) anclado a un fenómeno, contexto y temporalidad particulares, se adopta para el abordaje una perspectiva relacional y transdisciplinar.

La perspectiva relacional es una orientación de metodológica del contextualismo radical propuesto por Stuart Hall que rechaza cualquier postura universalista y promueve situar el análisis. Mientras que el enfoque transdisciplinar se plantea como una opción necesaria en tanto se asume como tal el propio estatuto del campo de la comunicación. Dicho estatuto se delinea con fuerza luego que las reflexiones en este ámbito sufrieran un viraje de 
sus intereses “de los medios a las mediaciones”, como advirtiera Jesús Martin Barbero en los años 80’.

Asimismo, esa visión relacional y transdisciplinar busca dar cuenta de la multidimensionalidad de los procesos comunicativos a partir de una articulación de los aportes de distintas disciplinas sociales en el abordaje y, justamente, la problemática de la vida de las fotografías entre las prácticas y los discursos forma parte de esos procesos complejos y de carácter multidimensional.

En esta línea, el presente trabajo se funda en una propuesta teórica- metodológica que privilegia diversos aportes provenientes de los estudios culturales y los estudios latinoamericanos de la comunicación, los estudios visuales; así como de los estudios semióticos de la fotografía y la antropología visual, la historia cultural, la historia del arte y de la fotografía.

Por otra parte, el análisis desarrolla una operatoria analítica contrastiva que sigue los supuestos de Caggiano (2012), quien recalca la necesidad de prestar atención a la intersección de las imágenes (por ello la comparación de las fotos actuales con las históricas) para dar cuenta de la reproducción de miradas hegemónicas y también de las miradas descentradas. En este marco, la indagación toma herramientas del paradigma iconográfico - indiciario y la lectura performancial para el análisis de la dimensión representacional de la imagen fotográfica y los actos fotográficos en diálogo con otros textos, respectivamente. También se nutre aportes del método de la "economía visual" (Poole, 2000) para el abordaje transversal de la producción, circulación y recepción de las imágenes.

\section{Algunos antecedentes.}

Si bien no se conocen trabajos que remitan específicamente al análisis de fotografías de la festividad y de la figura del Gaucho Gil desde la perspectiva propuesta, se pueden citar algunos escritos de referencia en relación a las inquietudes de esta tesis.

Del ámbito de las reflexiones internacionales es significativo el artículo Retratos en acción: la España de Cristina García Rodero de Stanley Brandes (2005), que analiza las fotografías de las fiestas religiosas españolas que la fotógrafa Cristina García Rodero vuelca en el libro "España Oculta”. Allí el antropólogo rescata la dimensión etnográfica que estas imágenes aportan para comprender diversos aspectos de las tradiciones y la cultura popular española; así como la importancia de la visualización de la dimensión expresiva del cuerpo en plena relación con el estado espiritual de los retratados, como signos articuladores de la 
religiosidad.

Por otra parte, son de referencia obligada $E l$ dios fotogénico. El festejo religioso a través de la imagen fotográfica (2004) y Fotografía, muerte y religiosidad (2006), textos de José Sánchez Montalbán, que reflexionan sobre el festejo religioso y los rituales de recordación de los difuntos a través de la fotografía. Estos trabajos además de reconocer el valor documental, contribuyen a entender el rol creativo y activo de la fotografía en la producción de sentidos en el ámbito de prácticas rituales y/o religiosas. Aportan así por un lado, a la superación de la consideración de la foto como mera ilustración y la rescata como documento válido a ser analizado con el mismo rigor científico que el discurso verbal/escrito atendiendo a las especificidades que su abordaje requiere y, por el otro, a ser entendido como espacio de mediación de y con el pasado y el recuerdo; pero a la vez como mediador, interfaz de contacto, entre el más allá y el más acá, entre muertos y vivos.

Por otra parte, el antecedente más cercano que trata la performatividad de las representaciones visuales ligadas al Gaucho Gil, aunque no se detiene en el análisis de fotografías, constituyen unas breves líneas de La santidad popular de los bandidos rurales. El culto al Gaucho Gil, tesis de maestría de San Juan Suárez (2010). Allí el autor aborda el cadáver y la tumba del gaucho perseguido convertido en "santo" popular junto a las estampitas del difunto santificado, entre otras imágenes circulantes sobre la divinidad, como "superficies o volúmenes significantes; sedes de afección y simpatía; entidades sensibles e inteligibles, significativas".

Respecto al análisis específico de las producciones de "autor" que nos ocupan, el caso de Guillermo Rusconi y Juan Pablo Faccioli se retoman algunos trabajos propios publicados en diversos ámbitos (2011, 2012, 2013 y 2014) y, de Marcos López son de consulta Debut y despedida. Fotografias de Marcos López, 1978-2009, ensayo de Valeria González (2010) y Marcos López y la década del noventa: radiografía fotográfica del neoliberalismo criollo, tesis de licenciatura de Estefanía Miguel (2013).

En relación a la foto de religiosidad analizada desde el acto que la produce no hemos hallado antecedentes regionales, no obstante es de referencia Mirarse y agenciarse. Espacios estéticos de la performance fotográfica, estudio Buxo i Rey (1998) quien desde la antropología visual y con un corpus variado aborda especialmente interacción entre fotógrafo y fotografiado, la escenificación, la pose y la capacidad de agencia de los sujetos retratados ante la cámara. El trabajo etnográfico y descriptivo de los actos fotográficos sigue de alguna manera algunos planteos teóricos-empíricos ya realizados por Barthes (1989), Bourdieu (2004), Edwards (1992), Green (2007), entre otros. 
Por último, aunque las imágenes analizadas se alejan del tópico de la religiosidad, son lecturas referenciales en el ámbito regional y nacional los trabajos de Mariana Giordano, Carlos Massota, Sergio Caggiano y Alejandra Reyero. Particularmente, Discurso e imagen sobre el indígena chaqueño, estudio de Mariana Giordano (2004) brinda una reflexión de la fotografía entendida como "artefacto" de producción de sentido no inocente que vehiculiza representaciones ideológicas específicas. La autora explicita el carácter de la foto como construcción cultural y “agente” ideológico de dominación y control; así como brinda algunas lecturas de reconstrucción histórica de cómo se construyó en la Argentina la imagen de un "nosotros" y "otro" según el eje de civilización y barbarie.

En el caso del antropólogo Carlos Masotta, de su trabajo Representación e iconografía de dos tipos nacionales. El caso de las postales etnográficas en Argentina 1900 - 1930 (2004), es de interés el análisis, además de las postales de indios, especialmente las de gauchos en tanto estereotipos que se construyen a través de la imagen postal para aludir a la identidad nacional en el marco de los debates de la construcción de la Nación en el Centenario argentino.

Del libro El sentido común visual. Disputas en torno a género, "raza” y clase en imágenes de circulación pública (2012), de Sergio Caggiano, más allá del material heteróclito analizado, resaltamos la perspectiva de abordaje que apunta no sólo a analizar los repertorios hegemónicos sino también aquellos alternativos posibles en torno a los imaginarios establecidos, haciendo hincapié en los descentramientos que pueden plantear desde la autorepresentación los grupos aludidos por las representaciones oficiales; y también en la diversidad de ámbitos de circulación de los que se ocupa, donde la web aparece como un espacio "otro" de difusión/legitimación de imaginarios a atender.

Finalmente, de La construcción de la imagen del otro como creación de disenso. Usos y sentidos de la fotografía etnográfica chaqueña en tiempos de estetización de la experiencia (2014), tesis doctoral de Alejandra Reyero, interesa el abordaje de las relaciones entre la práctica fotográfica y el contexto artístico contemporáneo; específicamente su reflexión sobre los modos en que la fotografía documental y etnográfica de las comunidades indígenas, considerada históricamente alejada de esfera del arte, a fines de siglo XX y principios del XXI ingresa y es legitimada en este espacio, planteándose más allá del registro documental antropológico construido en base a una ideología colonizadora, como una mirada poética y estética que puede dar lugar a otras lecturas. 


\section{Itinerarios del texto, ingresos de lectura posibles}

La tesis se organiza en dos grandes partes. La primera se denomina Del problema al enfoque de análisis y se divide en dos capítulos de reflexiones y posicionamientos teóricometodológicos con algunas aproximaciones analíticas. La segunda parte se denomina Del caso a las apropiaciones fotográficas y se divide en cuatro capítulos que analizan diversas dimensiones de las fotografías que forman parte el corpus central -las imágenes de autor- en relación con fotografías históricas recolectadas en archivos, la web y trabajos de campo en la propia festividad del Gaucho Gil en Mercedes, Corrientes, otras iconografías y textualidades lingüísticas relacionadas, notas de observación de campo y entrevistas realizadas durante la investigación.

En este marco, el Capítulo 1 presenta las preguntas que guían la indagación y parte de ellas para recuperar los debates teórico-metodológicos sobre la re-representación fotográfica. En función del caso, del corpus y el problema planteado se recuperan cinco posibles ingresos de lectura de la imagen. Ellos hacen mención a la consideración de la re-presentación fotográfica como huella, documento y artefacto cultural; dispositivo entre miradas y relaciones de saber/poder; como imagen anacrónica, actos de imagen y modo de presencia; como actante con doble poder o potencia per-formativa $\mathrm{y}$, finalmente, como imagen-acto e imagen-identidad. Cada uno de estos ingresos actualiza algunos presupuestos desarrollados por la historia de la fotografía, la semiótica, la historia cultural, la historia del arte, los estudios visuales y culturales, la comunicación y la antropología visual que son retomados en la construcción del enfoque de análisis relacional y transdisciplinar que se define en el Capítulo 2; así también estos ingresos guían las reflexiones analíticas de las fotografías en la segunda parte.

El Capítulo 2 recupera algunos debates sobre la relación de la fotografía con las identidades que se les atribuyen en diferentes instancias de producción de sentidos y con las nociones de religión, religiosidad(es), religiosidad [de los sectores] popular[es]; prácticas religiosas y/o prácticas de sacralización, entre otros. Asimismo, establece algunas líneas de lectura para pensar las fotografías de la festividad del Gaucho Gil y las apropiaciones de la figura del "santo" popular desde las imágenes, incluso aquellas re-creadas fuera de la festividad, desde el campo de la comunicación y la cultura atendiendo particularmente las discusiones sobre el "campo religioso heterogeneizado".

En esta línea, en la segunda parte de la tesis, el Capítulo 3 plantea una aproximación teórico-analítica al desarrollo de la dimensión predominantemente visual -iconográfica y 
fotogénica- en las prácticas socioculturales -aquellas religiosas y las que exceden dicho dominio- vinculadas a la festividad y a la figura del Gaucho Gil hacia fines del siglo XX y principios del siglo XXI. Es decir, desde fines de los años 1970 y principios de 1980 en que la devoción empieza a visibilizarse hasta 2013, año de la última producción de fotos incorporada en el corpus. Asimismo, aborda el tejido de representaciones identitarias y el potencial performativo que entrama la imagen más difundida del "santo" popular. Al respecto, indaga la historicidad, es decir, el espesor temporal de esta representación que, según conjeturamos, desde que se plasmó en una forma iconográfica hacia la década del ochenta (el bulto escultórico de un gaucho en su santuario y una estampita reproducida y re-significada en diversos objetos, cuerpos e instancias de producción de sentidos) adquirió una popularidad inusitada. El texto analiza los posibles factores que influyeron en la propagación de esta devoción en el territorio nacional, incluyendo el rol de la fotografía, y los modos en que el icono de este "gaucho de los milagros" actualiza y re-crea marcas de identidad históricamente densas a través de su reproducción en prácticas y dispositivos de difusión diversos.

El Capítulo 4 reflexiona sobre las políticas de la mirada y la memoria desde las que se construyeron representaciones hegemónicas de religiosidad correntina, en buena parte restringidas a la referencia de los cultos oficiales -aquellos promovidos por la iglesia católica y una élite social y política desde fines del siglo XIX y buena parte del siglo XX- y las prácticas y mecanismos que apuntan a la desestabilización de esas representaciones instituidas. El análisis adopta un carácter contrastivo que parte de una experiencia de búsqueda de fotografías históricas de la religiosidad archivos fotográficos, centrándose en los detalles del relevamiento en el Museo Histórico provincial y el Archivo General de la Nación para reflexionar cómo los procedimientos constitutivos de este espacio/artefacto/dispositivo de construcción de memorias, vinculados a regímenes históricos de in-visibilidad particulares, influyeron en la mostración y la in-visibilización de determinadas imágenes y no otras de la religiosidad provincial en una determinada época.

En el marco de los procesos antes descriptos, en el Capítulo 5 se analizan las imágenes de los cinco fotógrafos seleccionados, haciendo hincapié en la reconfiguración de representaciones de la religiosidad correntina que plantean los recortes fotográficos de estos autores y cuáles son los mecanismos de descentramiento de la mirada que opera en sus prácticas fotográficas. Aquí, se presta atención a los modos compositivos, los elementos que dan a ver y aquellos que ocultan, a quiénes muestran y cómo lo hacen y a través de qué espacios de circulación/mostración y mediados por qué intereses las imágenes circulan. En ese sentido, el análisis de los diferentes modos de dar a ver el "mundo" del Gaucho Gil de 
Faccioli, Rusconi, Longoni, Izuel y López se plantea a modo de pasajes de un tipo de recorte a otro y de una búsqueda conceptual a otra. En esos pasajes se observa cómo las imágenes condicionadas por un punto de vista en la producción y de su posterior valoración en la circulación, pueden ser investidas de diversos sentidos. También, se reflexiona sobre los modos en que se construyen las imágenes a partir de nuevas informaciones que le imprimen los autores en diálogo con la cita de narrativas y retóricas identitarias históricamente densas; y sobre los factores que inciden en el potencial performativo de algunas fotografías.

El Capítulo 6 realiza una reflexión de capturas fotográficas y la observación de actos fotográficos siguiendo la trayectoria de fotografiar de Juan Pablo Faccioli y Guillermo Rusconi en la festividad del Gaucho Gil, en Mercedes Corrientes en 2010 y 2011. Desde los estudios de la comunicación/cultura y en el marco de las discusiones respecto de la cultura popular-masiva, el apartado analiza la configuración emotiva de las re-presentaciones fotográficas producidas por estos autores. Aborda la (re) creación del melodrama en estas imágenes puestas en relación con sus matrices culturales históricas. Asimismo, analiza el acto fotográfico como un espacio de articulaciones dialógicas y de proyecciones identitarias, donde los retratados pueden asumir, en determinadas instancias, el rol de co-productores de las imágenes. Aquí se adopta una lectura performancial de la fotografía desde el acto que la produce, a partir de observaciones de campo y entrevistas. En este ámbito de producción se analizan las relaciones posicionales y de poder que la fotografía articula y finamente se propone nociones para re-pensar la vinculación entre fotografía, religiosidad y la configuración de memorias e identidades desde el estudio de las prácticas de fotografiar.

Finalmente, cabe aclarar que los capítulos dialogan entre sí, se conectan a partir de citas, referencias y remisiones lo que, sin embargo, no impide la posibilidad de la lectura de cada uno de ellos de manera relativamente autónoma. Se insiste en la relatividad puesto que la tesis apuesta a una lectura predominantemente relacional y dialógica que se nutre de desarrollos previos y realiza constantes reenvíos a nuevas interrogaciones. En este sentido, el entretejido textual adquiere una dinámica de pasajes y busca, frente a la complejidad del tema y del corpus abordado, analizar en cada incursión diferentes dimensiones o aspectos de las imágenes para dar cuenta de la movilidad de los sentidos atribuidos.

\section{Alcances y limitaciones de la indagación}

Consideramos que esta indagación aporta algunas reflexiones a los estudios de la comunicación relacionados específicamente al abordaje de la fotografía, el problema de las re- 
presentaciones visuales de prácticas religiosas, a su vez relacionadas a prácticas y procesos socioculturales heterogéneos, y su rol en la configuración de memorias e identidades. A la vez, colabora con la comprensión reflexiva sobre la fotografía como objeto y herramienta de análisis capaz de acercarnos de un modo hasta ahora poco explorado a las "prácticas religiosas" o "prácticas de sacralización" en general y a la festividad del Gaucho Gil de la provincia de Corrientes en particular; aunque cabe advertir que la tesis no se propone un abordaje de las prácticas, rituales y/o configuraciones de la religiosidad popular propiamente dicha desde las perspectivas tradicionales de la antropología o la sociología de la religión, sino reflexionar sobre el rol de las imágenes en esas formaciones socio-culturales.

En esta trayectoria de lecturas y análisis, las conclusiones del trabajo retoman los objetivos y los interrogantes iniciales de la investigación para poner en discusión una hipótesis que hemos tomado como punto de partida y es la siguiente:

Las re-presentaciones fotográficas forman parte de complejos procesos comunicativos en los que actúan configurando diversos sentidos desde y sobre las prácticas de religiosidad popular de la provincia de Corrientes. Estas imágenes, a partir del despliegue de una serie de estrategias en función de regímenes de (in)visibilidad e intereses de quienes las manipulan y concebidas desde el acto que las producen, una vez puestas a circular en instancias y espacios discursivos diversos, construyen representaciones hegemónicas y/o alternativas de la religiosidad correntina. De este modo las fotografías configuran las prácticas y no solo vehiculizan significaciones existentes sino que las re-crean y re-significan. Asimismo las fotos conforman superficies expresivas visuales con alta capacidad perfomativa $y$, en tanto textos revelan huellas que permiten establecer vinculaciones de matrices de la cultura popular y masiva. Por otra parte, configuran formas de articulación atravesadas de experiencias de encuentros entre fotógrafos y fotografiados, posiciones y relaciones de poder, hecha de diálogos, tensiones y negociaciones, que cumplen un rol activo en la dinámica de fijación y des-estabilización de memorias e identidades.

En la línea de dicho supuesto podemos indicar que el eje vertebrador de la tesis es la indagación sobre el poder de las re-presentaciones fotográficas para motivar la orientación de la concepción de los hombres sobre determinados temas y su re-acción en ciertos contextos específicos frente a determinados hechos y situaciones. Es decir, el análisis está centrado en las imágenes fotográficas y sus modos de inserción y participación en procesos culturales específicos, comprendiéndolas no necesariamente se como reflejo fiel de la realidad, sino como formas que pueden plantear un rol activo en la construcción de lo real. 


\section{PRIMERA PARTE:}

DEL PROBLEMA Y EL ENFOQUE AL CASO DE ANÁLISIS 


\title{
CAPÍTULO 1:
}

Debates y posiciones teórico-metodológicos: la re-presentación fotográfica

\begin{abstract}
La vista llega antes que las palabras. El niño mira y ve antes de hablar(...). Pero el hecho de que la vista llegue antes que el habla, y que las palabras nunca cubran por completo la función de la vista, no implica que ésta sea una pura reacción mecánica a ciertos estímulos...

Una imagen es una visión que ha sido creada o reproducida. Es una apariencia, o conjunto de apariencias, que ha sido separada del lugar y el instante donde apareció por primera vez y preservada por unos momentos o unos siglos. Toda imagen encarna un modo de ver. Incluso una fotografia, pues las fotografias no son como se supone a menudo, un registro mecánico....
\end{abstract}

John Berger, Modos de Ver

Las relaciones entre la fotografía, las representaciones, las prácticas sociales y las prácticas discursivas configuran extensos debates que han sido abordados por diversos autores de las ciencias sociales. En este capítulo nos ocupamos de rescatar algunos de esos debates y enfoques para pensar los modos en que algunas fotografías intervienen en la recreación/producción de las prácticas socio-culturales, entre ellas las "prácticas religiosas" o "prácticas de sacralización"18, así como en la construcción de las memorias e identidades, haciendo foco en el caso de los actos fotográficos y las imágenes capturadas entre 1999 y 2013 en, desde y sobre la festividad del Gaucho Gil, que se desarrolla en la provincia de Corrientes, Argentina.

En esta línea, los abordajes que siguen parten de los interrogantes específicos que nos planteamos sobre el tema para esbozar el marco de abordaje teórico y metodológico, fundado primordialmente en las propuestas de los estudios latinoamericanos de la comunicación, los estudios culturales y los estudios visuales -entendiendo a estos campos de reflexión como espacios que se abren al entrecruzamiento de aportes provenientes de otras disciplinas de las ciencias sociales y humanas -.

La indagación de los modos en que las fotos intervienen/producen la re-creación de las prácticas religiosas vinculadas a la festividad del Gaucho Gil y la figura central de este "santo" popular nos llevó a preguntarnos como punto de partida: ¿De qué modo y a partir de qué estrategias discursivas las fotografías construyen representaciones hegemónicas y/o

\footnotetext{
${ }^{18}$ Los debates en torno a estas nociones se desarrollan en el Capitulo 2.
} 
alternativas ${ }^{19}$ de las prácticas religiosas?; ¿en relación a qué otros textos y en qué contextos?; ¿cómo las re-presentaciones fotográficas proliferan y de qué modo logran anclarse en la memoria colectiva?; ¿cómo se construyen los actos fotográficos?; ¿Cómo los sujetos invisten de sentido a estos actos e imágenes en circulación social?; ¿de qué modo se tejen relaciones de poder entre fotógrafos y fotografiados e instituciones diversas desde las diferentes instancias de producción y reproducción de fotografías?; y ¿cómo estos actos de ver, fotografiar y re-presentar intervienen en procesos de des-estabilización de repertorios de memorias e identidades cristalizadas ${ }^{20}$ y en la re-producción de las "prácticas religiosas y/o de sacralización” en sí?.

Esta serie de planteos nos condujo en primer lugar a revisar y discutir la noción de representación fotográfica $(\mathrm{RF})$ desde la consideración de su interacción con lo social y lo discursivo. El bosquejo del mapeo teórico realizado apunta por un lado, a pensar la "transitoriedad histórica" de un concepto; es decir pensar el modo en que la re-presentación fotográfica adquiere diversos sentidos según las posiciones de sujeto, las modalidades de interpretación de los problemas y la situación contextual e histórica que la ancla y atraviesa; y por el otro, persigue elaborar una "caja de herramientas" no restringida a una escuela particular sino más bien tendiente a construir una mirada relacional, dialógica trasdisciplinar de abordaje que permita dar cuenta de la identidad inestable y ambigua de la fotografía, la fijación provisoria de sus sentidos ${ }^{21}$.

En esta orientación, este mapeo considera algunos ingresos de reflexión para pensar la re-presentación fotográfica $(\mathrm{RF})$ en su vinculación con las prácticas y los discursos, la configuración de memorias e identidades: 1) La RF entendida como huella, documento y artefacto cultural; 2) la RF como dispositivo entre miradas y relaciones de saber/poder; 3)

\footnotetext{
${ }^{19}$ Referimos a los repertorios visuales hegemónicos y/ o alternativos a los que hace mención Caggiano (2012). El autor, partiendo de la concepción de hegemonía de Raymond Williams, piensa las propuestas visuales estabilizantes, productoras y reproductoras del "sentido común visual” en contraposición o en intersección, diálogo con aquellas "más o menos confrontativas, más o menos autónomas" que enfrentan o desconocen las propuestas hegemónicas (Caggiano, 2012: 53). En este sentido, algunas propuestas alternativas pueden plantear una posición contrahegemónica, aunque no necesariamente, incluso en el ámbito de lo popular. De este modo, Pablo Semán echa por tierra la idea de una movilización contestataria constante de las culturas populares en la lucha por la legitimación y asevera "también descansan" (Semán, 2009).

${ }^{20}$ Alude a una práctica fotográfica reflexiva capaz de instrumentalizar una de serie de mecanismos y/o estrategias (tácticas) de descentramiento de la mirada, de de-construcción y de re-producción de repertorios estabilizantes, tales como algunos repertorios oficiales, que se presentan como dados, normalizados y en muchas ocasiones esencializadores de las memorias, las identidades, los territorios. Esta idea se desarrolla en el Capítulo 4 y 5 .

${ }^{21}$ Siguiendo los planteos realizados por Williams y otros referentes de los Estudios Culturales, Nelly Richard sostiene que la opción de esta perspectiva teórica es construir "una caja de herramientas" no reducida a una escuela, descartando la primacía de "postura académica autosuficiente" (Richard, 2010: 34). Cabe señalar que también en Deleuze y Foucault hay referencias sobre la necesidad de concebir a la teoría como "caja de herramientas" (Deleuze y Foucault, 1972; Foucault, 1985).
} 
la $R F$ como imagen anacrónica, actos de imagen y modo de presencia; 4) la RF como actante con doble poder o potencia per-formativa y 5) la RF como imagen-acto e imagen-identidad.

Estos ingresos dan cuenta de las múltiples dimensiones de análisis a partir de las cuáles podemos aproximarnos a las imágenes. Los desarrollos que siguen son retomados en la definición del enfoque de análisis relacional y trasdisciplinar planteado en detalle al final del Capitulo 2 y constituyen las herramientas teórico-conceptuales para el análisis de las imágenes que se realiza en la segunda parte de la tesis.

\section{La RF como huella, documento y artefacto cultural}

La fotografía desde sus inicios (Francia-1839) fue considerada un procedimiento de registro excepcional capaz de "reflejar" de manera "fidedigna" aspectos de la vida social y cultural. Por su relación de semejanza y continuidad indicial con su referente, en función de intereses y visiones de mundo específicas, se la llegó a considerar como un "espejo de lo real". Sin embargo, esa concepción de esencia mimética se transformó al tiempo que los estudios reconocieron el valor testimonial y documental en la foto desde una visión crítica, a la vez que observaron en ella un artefacto cultural que permite al creador construir su versión de lo real.

Hacia mediados del siglo XX comenzó a instalarse la concepción de la fotografía entendida como herramienta de transposición, de interpretación y hasta de transformación de lo real. Esta noción vino a cuestionar esa condición de objetividad o fidelidad adjudicada originalmente a la imagen fotográfica.

En ese contexto, se comprendió que el fotógrafo, en base a intereses particulares e influencias contextuales específicas, selecciona un fragmento de un determinado acontecimiento dejando de lado otros aspectos del mismo. En otras palabras, se observó que detrás de la cámara hay un ojo que realiza ese "recorte" de la realidad precedido por un concepto, a su vez mediado por convenciones e imaginarios colectivos ${ }^{22}$.

Entonces la fotografía empezó a ser entendida como la construcción de la mirada, y ésta como una manifestación y producto del contexto social, cultural, estético, político e ideológico. Es decir, se postuló una mirada para nada inocente de lo real. Pierre Bourdieu señala al respecto:

\footnotetext{
${ }^{22}$ Esta idea de recorte de lo real ha llevado a Dubois (2008) a definir a la foto ante todo como un acto que implica un juego de intereses y subjetividades diversas.
} 
“...la fotografía no puede quedar entregada los azares de la fantasía individual y, por la mediación del ethos - interiorización de regularidades objetivas y corrientes - el grupo subordina esta práctica a la regla colectiva, de modo que la fotografía más insignificante expresa, además de las intenciones explícitas de quien la ha tomado, el sistema de esquemas de percepción de pensamiento y de apreciación común de todo un grupo" (Bourdieu: 1979: 18).

Hasta aquí interpretaciones diversas coinciden en concluir preliminarmente que la fotografía presenta al menos dos dimensiones: la de testimonio/documento; o bien la de artificio/creación ${ }^{23}$ (Kossoy, 2000).

En nuestra tarea de historizar las representaciones ${ }^{24}$, una mirada retrospectiva más detenida sobre estas dimensiones nos llevan a advertir que el relato científico tecnocentrista del siglo XIX ocupó un rol fundamental en la consideración de la foto como el registro "más fiel de lo real".

Dicha posición es llevada al extremo en la narración de sus inventores/ promotores comerciales Daguerre y Talbot $^{25}$ que resaltaron la capacidad del procedimiento técnico para documentar fielmente la realidad prácticamente sin mediar la intervención del hombre. En este sentido, Talbot señala en el texto The Pencil of Nature que la foto surge por la "mera acción de la luz sobre papel sensible" e insiste en que las imágenes resultan "grabadas por la mano de la naturaleza (...) sin ninguna ayuda del artista" (Talbot, en Cortés Roca, 2011: 31).

En esa línea, como señala Rancière, la fotografía venía a "encarnar la idea de la imagen como realidad única resistente al arte y al pensamiento" (Rancière, 2010: 108) que desde esa insistente negación de su estatuto de arte también se le negaba a la imagen su carácter de objeto fabricado.

\footnotetext{
${ }^{23}$ El reconocimiento de esta doble dimensión de la representación fotográfica sólo hace mención a una de las múltiples lecturas en clave dilemática que ella ha generado. Las discusiones al respecto pueden consultarse en Barthes (1989), Kossoy (2000), Bourdieu (2003) Sontag (2005), Soulages (2005), Berger (2006), Dubois (2008) y Lemagny (2008). Asimismo son extensos y para nada conclusivos los debates sobre las modificaciones de los regímenes perceptivos de lo visual o la configuración del nuevo "sensorium" de la época moderna leídos desde la experiencia fotográfica en los que aquí no nos detenemos y sobre los que han explayado Sorlin (2004), Fontcuberta (2003; 2010), Benjamin (1989), entre otros.

${ }^{24}$ Esta tarea se enmarca por un lado en la necesidad de caracterizar los tipos de discurso que las disciplinas científicas construyeron en torno a la fotografía entre el siglo XIX y XX, sosteniendo con ello determinados regímenes de verdad que configuran la formación discursiva de estos periodos. Por otro lado, se debe a que la descripción somera de estos discursos permite dar cuenta de los patrones de significación provenientes de diferentes instancias socio históricas que actualizan las representaciones actuales y es lo que Cebrelli y Arancibia (2005) el espesor temporal de las representaciones y las imágenes asociadas a ellas.

${ }^{25}$ Los primeros experimentos realizados por Nicephore Niepce en Francia llegan a las manos de Louis Daguerre que tras un acuerdo presenta el daguerrotipo en 1839 en la Academia de Ciencias y Bellas Artes en París y además consigue apoyo político y lo lleva a la Cámara de Diputados. Aquí, frente a los discursos potentes que realzan la utilidad de la tecnología para impulsar el progreso, las expediciones y el posicionamiento francés en el mundo, el invento es adquirido por el Estado. Por su parte Fox Talbot en Inglaterra crea el calotipo que reemplaza la copia en plancha metálica por el papel, siendo el procedimiento más difundido.
} 
Como contrapartida a mediados del siglo XX hasta nuestros días varios estudios interdisciplinarios de las ciencias sociales se ocuparon de develar que la fotografía lleva desde su origen el germen de transformación de lo real, partiendo de la propia necesidad de una toma de posición del fotógrafo en la captura y la dinámica de la producción de sentidos en la que se inserta el recorte, conllevando diversas operaciones de alteración.

En este sentido, escriben Pierre Bourdieu (1979) y Boris Kossoy (2001) sobre el recorte fotográfico, el filtro cultural y las subjetividades que intervienen la concepción de la imagen; también Joan Fontcuberta (2010) discute la noción de espejo de lo real poniendo el acento en el análisis de las manipulaciones tanto en instancias de preproducción (montajes, entre otras operaciones) como de posproducción (retoques de revelado o de intervención digital) que configuran las fotos actuales.

Por su parte, diversos investigadores de la historia social y cultural cuestionan la concepción de la foto como mera ilustración de los textos escritos para proponerla como un "testimonio ocular" de lo acontecido y "documento" no inocente sino construido.

$\mathrm{Al}$ respecto, Peter Burke postula que "al igual que los textos, los testimonios orales, las imágenes son una forma importante de documento histórico (...) Reflejan un testimonio ocular". Sin embargo, advierte que "los historiadores no deben limitarse a utilizar las imágenes como "testimonios' en sentido estricto" sino que "debería darse cabida también a lo que Francis Haskell llamaba "el impacto de la imagen en la imaginación histórica"” (Burke, 2001: 16-17).

Desde el campo de la semiótica, varios especialistas reconocen también su carácter construido, pero además insisten que la foto es ante todo vestigio del pasado, un presente fugaz retratado. Philippe Dubois indica en este sentido:

\footnotetext{
“...más allá de todos los códigos y todos los artificios de representación, ‘el modelo', el objeto referencial captado, inevitablemente retorna (...) Antes de cualquier otra consideración representativa, incluso antes de ser 'imagen' que reproduce las apariencias de un objeto, una persona o un espectáculo del mundo, ante todo, es esencialmente, es el orden de la huella, de la traza, de la marca(...) pertenece a toda una categoría de signos" ( Dubois, 2008: 44-55).
}

De esta manera, retomando la relación triádica del signo planteada por Charles Peirce, Phillippe Dubois resalta el carácter de index de la fotografía desde su relación de conexión con el referente. Es decir, reivindica el modo en que la imagen se plantea como una emanación del referente, o más bien, parafraseando a Roland Barthes (1989), cómo la fotografía se define a partir de la obstinación del referente de "estar siempre ahí". 
Asimismo, Barthes habla de la muerte como presencia inseparable de la fotografía, como un acto de suspensión del continuum vital, poniendo el acento en cómo la imagen dice siempre "lo que ha sido". Esta reflexión le sirve a John Tagg (1988) para ser aún más contundente en su revisión de esta relación dialéctica de presencia/ausencia bartheana que opera en la relación referente- foto-espectador y afirma: "La imagen que llega a la mente es la fotografía como máscara mortuoria (...) esa máscara significa lo mismo que 'ha sido y ya no es"” (Tagg, 1988: 8).

La noción de ausencia de lo real se complejiza mucho más en el marco de lo que Foncuberta (2010) llama la "era de la posfotografía", donde la construcción fotográfica está más bien regida por la lógica del montaje o de las intervenciones manuales o digitales ya sean explícitas y consensuadas como ocultas o disimuladas que refuerzan la ilusión de verdad del documento. Aquí se realza su carácter de dato icónico manipulable e integrable a ensamblajes diversos.

Al respecto, recuperando la mirada de Ronald Kay (1980), el investigador chileno José Pablo Concha Lagos refuerza esa idea de la foto como transformación de lo real, incluso más allá de su condición digital o analógica. Este autor realiza un análisis del procedimiento técnico, donde evidencia los distintos niveles de abstracción que ejercita el hombre para lograr la imagen técnica; así también da cuenta de las resonancias de ese producto en la cultura que implican distintas formas de relacionarse con él e investirlo sentido. La reflexión no sólo confirma el carácter construido de la foto sino que significa para el autor "la emancipación de la imagen del objeto" (Concha Lagos, 2004: 75).

En definitiva, este marco de referencias indican el modo en que el proceso semióticodiscursivo, anclado en la praxis social y condicionado por formaciones históricas y regímenes de valoración específicos, se presenta como el lugar donde aquello que fue en algún aspecto retorna pero también se transforma; lo real se "ficcionaliza" para ser pensado, al decir de Rancière (2008), y cobra nueva vida, se re-significa permanentemente.

De este modo, de la noción de imagen fotográfica entendida como documento y evidencia histórica que funciona en determinados contextos a modo de "prueba" de lo acontecido, en tanto conserva una "traza de lo real" congelada en la trama de la imagen (Barthes, 1989; Dubois, 2008); se pasa a la fotografía comprendida además como "artefacto" de producción de sentidos.

Cuando hablamos de "artefacto" nos referimos en términos de Jan Mukarovsky (1977) -quién teoriza desde semiótica del arte- a un objeto físico-material con propiedades y estructura específicas moldeada por alguien que adquiere un valor estético -cultural cuando se 
pone en relación con conciencia colectiva que le otorga significación. En términos del autor esta relación configura el "objeto estético"; esto es equiparable a lo que Mijaíl Bajtín (1989) entiende como una formación que nace en las "fronteras de lo material" en tanto surge de la relación entre la conciencia creadora y la contempladora, igualmente creativa que le otorga nueva vida al objeto estético.

En otros términos, referimos a la fotografía como artefacto cultural, no restringido al campo de las artes, en tanto está socialmente construido, supeditado al decir de Jean-Marie Schaeffer a convenciones de uso y de circulación social; al "servicio de estrategias de comunicación diversas" (Schaeffer, 1990: 8).

Desde el campo de la antropología visual, Belting define al artefacto como "la obra en imagen, la transposición de la imagen y los procedimientos con los que ella se obtiene" (Belting, 2007: 15) e insiste que no puede ser comprendida sin el "medio" que la corporeiza a la imagen, que la hace visible, perceptible; señalando también que cobra sentido en el cruce de las miradas que plantean siempre una orientación valorativa hacia/del mundo.

Por otra parte, interesa atender a la fotografía en tanto ámbito de construcción y reconfiguración de memorias e identidades, un "dispositivo" no exento de manipulaciones con fines estéticos e ideológicos (Agamben, 2011; Deleuze, 1991; García, 2012).

Se volverá sobre la noción de dispositivo y los aportes de Belting más adelante ${ }^{26}$, pero por el momento es suficiente señalar que esta compleja perspectiva de "lo fotográfico" permite entender la re-presentación fotográfica como artefacto/medio atravesado por prácticas y representaciones socio-históricas e ideológicas que además de "archivar y hacer circular con fluidez conceptos ideológicos complejos" (Cebrelli y Arancibia, 2005), de reproducir, también interviene en la producción creativa de de esos sistemas de valores y modelos de mundo.

Concebida como "dispositivo formateador performativo", la re-presentación fotográfica puede dar lugar a la emergencia de representaciones alternativas y otras que vehiculizan formas dominantes de ver y valorar el mundo, adquiriendo así un rol fundamental “en el funcionamiento de los engranajes de saber y poder" (García, 2004 y 2014).

A ello refiere Gisele Freund (1993) cuando en su historización de la fotografía insiste en la necesidad de superar la consideración de la fotografía como documento ingenuo que "aparentemente" otorga a la historia del conocimiento científico el procedimiento de reproducción "más fiel e imparcial" de la vida social, para entender que el estudio de la

\footnotetext{
${ }^{26}$ Ver apartado 3 y 4 respectivamente.
} 
máquina fotográfica, sometida a toda clase de "manipulaciones" que respondieron desde su aparición a variados intereses, es inseparable de una historia social y política.

Esto convoca a reflexionar sobre las implicancias de la consideración de la fotografía como tecnología emblema de los descubrimientos del siglo XIX. Es decir, observar el modo en que éste símbolo de progreso moderno, incluso desde su definición como instrumento de “conocimiento"27, así como se configuró como medio democratización del arte también se constituyó en máquina de control y despliegue de poder, entre otros roles atribuidos.

Al respecto, resultan de relevancia los trabajos de Giordano (2004) y Ramón Gutiérrez (1997) sobre la construcción de la imagen del indio chaqueño y la historia de la fotografía en Iberoamérica respectivamente, o de Caggiano (2012) sobre las disputas en torno al género, "raza" y clase en imágenes de circulación pública; entre otros ${ }^{28}$. Giordano evidencia en su análisis el rol de la foto como "agente" de dominación y mestizaje cultural en la región del Gran Chaco argentino; mientras en esta misma línea, Gutiérrez describe su utilización como artefacto de colonización, medio posicionamiento de clase y formateo cultural en una extensión más amplia. En este sentido, Gutiérrez afirma:

"La fotografía actuó en América, como en Europa, como un elemento de autoafirmación de la nueva burguesía urbana, que pretendía encarar la modernización de nuestros países, aunque, en este caso satelizándolos y mimetizándolos con los del Viejo Continente" (Gutiérrez, 1997: 346).

Por su parte, Caggiano aporta a las discusiones por el poder, las hegemonías y contrahegemonías desde el análisis de repertorios visuales que parten de la problemática de la inmigración boliviana en la prensa gráfica para ampliar su mirada a álbumes de fotografías históricas de la Argentina, imágenes de libros escolares, de mujeres propuestas por otras mujeres en internet y de pueblos originarios que también circulan en la web. En este texto Caggiano, enfatiza el modo en que las imágenes configuran un "campo de batalla visual" que remite a tensiones y conflictos que traviesan el imaginario argentino y latinoamericano y que, desde ese lugar, "participan activamente de la producción” de estos imaginarios; "juegan un papel vital en la creación y re-creación de las comunidades y grupos desde los cuales nos imaginamos" (Caggiano, 2012: 287-88).

\footnotetext{
27 Según Foucault, el conocimiento usado para regular la conducta de los otros, implica constricciones y no puede entenderse por fuera de las relaciones de poder y viceversa. "No hay relación de poder sin la correlativa constitución de un campo de conocimiento, y no hay conocimiento alguno que no presuponga y constituya al mismo tiempo relaciones de poder" (Foucault 1977, en Hall 2010: 478). Asimismo esa relación de saber/poder trabaja a través de prácticas y tecnologías que responden a contextos y regímenes de verdad específicos. En ello se inscribe esta lectura de la fotografía como dispositivo de despliegue de poder que es trabajado en detalle en el apartado 2 del presente Capítulo.

${ }^{28}$ Valen citar aquí también trabajos sobre la representación visual de la alteridad indígena, en particular, y fotografía, colonialismo y modernidad, en general, de Martha Penhos (2005), Carlos Massota (2008), Juan Naranjo (2006), Margarita Alvarado y otros (2001; 2007), Luis Priamo (2007).
} 
En términos generales, estos textos citados a modo de ejemplo ratifican el poder de persuadir/incidir en los modos de concebir el mundo que adquiere la re-presentación fotográfica según sus usos y re-iteraciones. En esta línea, Cortés Roca resalta que las fotos a medida que capturan lo que vemos también "nos enseñan a verlo; ponen el mundo frente a nuestros ojos, mientras nos dice que eso nos pertenece" (Cortés Roca, 2011: 15). Por ello, también Freund insiste en que la importancia de la fotografía "no sólo reside en el hecho que es una creación" sino sobre todo porque "es uno de los medios más eficaces de moldear nuestras ideas y de influir en nuestro comportamiento" (Freund, 1993: 8).

En ese sentido, estas lecturas nos ayudan a aproximarnos al complejo mundo de las imágenes de religiosidad en general y su función pedagógica, aleccionadora y por ende política; y a su vez, permiten comprender el rol socio-político de las fotografías de "prácticas religiosas" o "prácticas de sacralización" correntinas abordadas en toda la tesis y, en especial, aquellas producidas en el siglo XX en contraste con las fotografías de principios de siglo XXI, entre ellas las imágenes de los cinco autores, que se analizan en profundidad a partir del Capítulo 4 y 5.

En definitiva, la perspectiva hasta aquí desarrollada se plantea una noción de representación fotográfica que se expone como superadora del concepto de mímesis. No se la

piensa sólo como aquello que está en lugar de su referente, que vuelve presente lo ausente o como signo que refiere en algún aspecto o carácter a su objeto, sino además como un principio activo que instituye, legitima nuevas formas y nos impone la presencia no sólo de lo representado sino del hecho y el acto mismo de representar (Marin 2009; Chartier 1992; Burucúa, 2006).

Al respecto, Louis Marin (2009) señala que la representación tiene tanto el poder de volver a presentar lo ausente como el de exhibir su propia presencia y construir con ello al sujeto que la mira. De este modo, las imágenes interpelan también por su potencia performativa y su capacidad de producir agenciamientos múltiples. Esta cuestión de la performatividad y la agencia de las imágenes que ampliaremos más adelante, implica pensar, desde la perspectiva de Gell (1998) retomada por Mitchell (2003) entre otros, a la fotografía como un elemento activo en la invención de la cultura; o bien atender la "vida" de las imágenes en el seno de la cultura como eje transversal del planteo de esta tesis.

\section{La RF como dispositivo entre miradas y relaciones de saber/poder}


Lo expuesto hasta aquí anula la posibilidad de seguir pensando la re-presentación fotográfica con la lente del tecnocentrismo y más bien exige recuperar los interrogantes y las categorías de las perspectivas constructivistas para atender los modos y las políticas que guían la ordenación/construcción/ re-significación de la mirada fotográfica.

Partiendo del supuesto que la mirada se presupone, al decir de Grüner (2001) "históricamente situada" y "culturalmente sitiada", consideramos que una de las vías de reflexión más productivas pasa por tratar una comprensión más exhaustiva de la foto como de artefacto cultural, como hemos venido desarrollando, así como de su consideración dispositivo configurado en el entretejido de las miradas y atravesado por relaciones de saber/poder.

Si bien la noción de dispositivo es desarrollada por Foucault en los años 60' para pensar casos específicos dentro de formaciones discursivas también particulares (dispositivos disciplinares), el concepto es retomado y ampliado por Gilles Deleuze ${ }^{29}$. Para este último, los dispositivos se conciben como máquinas ${ }^{30}$ de hacer ver y hablar/decir. Se conforman por visibilidades y enunciados, así también por líneas de fuerza y subjetivación, todas formaciones en las que se entretejen los juegos del saber y el poder correspondientes a /condicionados por una determinada formación histórica.

Así también, para los dispositivos fotográficos cada época histórica modula las líneas de visibilidad $^{31}$, de prácticas discursivas y no discursivas/formas de contenido que determinan/ generan lógicas y funcionamientos de visibilidades. Estas líneas establecen qué se incorpora dentro del recorte fotográfico de lo memorable y qué se deja fuera.

De allí que el fotógrafo ateniéndose a las reglas de su formación histórica, se configura en su acción de fotografiar como "emplazamiento" de los regímenes que cada época modula. Esta misma lógica regula la inserción de las imágenes fotográficas dentro de la maquinaria mediática u otros espacios de difusión/legitimación.

Dichos regímenes, siempre totalmente inmersos en relaciones de poder/saber, constituyen políticas de verdad y la mirada es un efecto de esa "verdad". Sin embargo, como

\footnotetext{
${ }^{29}$ Deleuze dirá que el dispositivo "es una especie de ovillo o madeja, un conjunto multilineal", compuesto de líneas (de visibilidad, enunciación, fuerza y subjetivación) "que siguen direcciones diferentes, forman procesos siempre en desequilibrio" y entiende que desenmarañarlas implica "en cada caso levantar un mapa, cartografiar, recorrer tierras desconocidas" (Deleuze, 1991:155).

${ }^{30}$ Interpretando a Foucault, Deleuze señala "toda máquina es un ensamblaje de órganos y de funciones que permite ver algo, que saca a la luz y poner en evidencia (la "máquina prisión", o bien las máquinas de Roussel)" (Deleuze. 1991:86).

${ }^{31}$ Cabe aclarar que las visibilidades, en términos del filósofo francés "no se definen por la vista sino que son complejos de acciones y de pasiones, de acciones y de reacciones, complejos multisensoriales que salen a la luz" (Deleuze, 1991: 87).
} 
indica Hall, en una misma formación social se pueden observar varios regímenes de verdad que "no son simplemente plurales sino que se definen en un campo de fuerza ideológico" y allí es posible observar la conformación de regímenes subordinados (Hall, 2010: 79).

En este marco, resulta necesario entonces dar cuenta también de los sentidos que trastocan los marcos de fijeza de los regímenes. Esto se da a partir de la irrupción dentro de los propios marcos que regulan las in-visibilidades de miradas "otras" que desafían las formas de constricción de esas "políticas de verdad".

Estas miradas "otras" dejan marcas graduales en el discurso, muchas veces imperceptibles en lo inmediato, que permiten re-pensar a futuro paradigmas, la redistribución de los regímenes de visibilidad como operaciones vitales para el mantenimiento del poder en el orden social. Más aún teniendo en cuenta que estos regímenes no se piensan ya desde una hipótesis represiva del poder sino más bien de una visión que lo concibe de modo relacional, posicional y estratégico (Foucault, 1992; Laclau, 2004; Hall, 2010). Hablamos de un poder que no simplemente impone sino que "produce" la realidad y ámbitos de objetos y rituales de verdad en vinculación con las demandas de los sujetos marginales que se constituyen dentro del discurso como efecto de la regulación normalizadora (Foucault, 1992, Butler, 2001).

En otras palabras, si bien la mirada surge como un producto de lo que instauran esos regímenes y éstos, a su vez, se re-producen como producto de la mirada, todo régimen, como dice Reguillo "comporta una franja de indeterminación potencialmente transformadora" (Reguillo, 2008: 2). Allí algunas miradas logran descentrarse para producir nuevas formas de ver, representar y por ende producir las prácticas sociales, desafiando y desestabilizando desde los márgenes esos esquemas estratégicos de visibilidad.

Esa idea de descentramiento de las miradas, la posibilidad de ejercer "miradas otras" es especialmente abordado en el Capítulo 4 y 5 al contrastar los diversos modos de mirar las prácticas religiosas o de sacralización que configura la festividad y la figura del Gaucho Gil en la práctica de fotografiar de los cinco autores en relación con re-presentaciones fotográficas históricas.

Vale señalar también que en esos lugares de indeterminación de los que habla Reguillo se configuran las zonas de fisura desde los cuales aquellos que disputan un espacio de visibilidad, tienen la posibilidad de ejercer el derecho de la "reciprocidad de la mirada del otro", ver y darse a ver ${ }^{32}$.

\footnotetext{
${ }^{32}$ El derecho a ver, dice Mirzoeff, "reclama autonomía, no individualismo ni vouyerismo, sino la reivindicación de una subjetividad política y colectiva: el derecho de ver, la invención del otro" (Mirzoeff, 2011, en Giordano 2014).
} 
Al respecto, en el ámbito del caso abordado no solo importan las imágenes que adquieren valor por su mostración-circulación en espacios legitimados por el Estado como los archivos o emprendimientos privados como algunos circuitos hegemónicos del arte; o aquellas imágenes que responden a intereses de consumo mediático producidas por fotógrafos profesionales; sino sobre todo aquellos repertorios alternativos que surgen de la necesidad de auto-representación de los propios sectores sociales populares. Hablamos de retóricas de identificación y distanciamiento con las formas de representación vigentes del fenómeno socio-cultural-religioso aludido; así como de diversas formas de actualización o subversión de iconografías circulantes desde los propios actos fotográficos, o las prácticas de resignificación desde los usos y apropiaciones de imágenes a través dispositivos digitales y difusión en la web que realiza la gente que siempre fue objeto de representación pero no tenía acceso a dar su visión del mundo frente a los repertorios establecidos.

Estos procesos son los que en términos de Mirzoeff dan lugar a analizar la "contravisualidad" como posibilidad de afirmar una ciudadanía que crea un mapa "otro" de lo social, influenciada por transformaciones sociales-culturales y tecnológicas amplias (como la explosión de la comunicación global digital y de internet).

Dicha concepción nos permite en esta tesis indagar, por ejemplo, el rol activo de las nuevas formas de comunicación, de las imágenes re-creadas y puestas a circular por los devotos del Gaucho Gil en la red en la conformación de identidades y otras ideas de la nación, entre otras cuestiones que se abordan en el Capítulo 3; o la reinvención iconográfica del "santo" popular no sólo en la práctica de fotografiar de los fotógrafos profesionales sino en los modos de construcción de "imágenes - identidad" por parte de los fotografiados a través de formas simbólicas de disposición del cuerpo y la mirada ante la cámara que nos ocupa en el Capítulo 6; o las diversas formas de re-significación de las imágenes de "autor" que la población realiza en instancias de recepción y consumo cultural, que se indaga en el Capitulo 5. En estos recorridos de reflexión es donde surge el interrogante sobre la posibilidad de la re-politización de la mirada (Mirzoeff, 2011; Richard, 2007; Giordano 2014).

Cabe señalar, que dicha lectura se articula con buena parte de las inquietudes de los estudios culturales ingleses y la crítica latinoamericana de la comunicación ${ }^{33}$, que retomando la noción de hegemonía de Antonio Gramsci y sus revisiones de la teoría frankfourtiana y

\footnotetext{
33 De estas perspectivas resultan trascendentes los estudios Stuart Hall, Edward P. Thompson, Raymond Williams y Richard Hoggart centradas en la desigualdad de lo social y la distinción de los materiales de la cultura como parte de una propuesta crítica de la cultura. Así como el desplazamiento del paradigma mediocéntrico hacia la reflexión de la comunicación desde la cultura que anuncian Martín Barbero, Héctor Schmucler, entre otros teóricos de la comunicación en América Latina.
} 
foucaultiana, convocan a entender la "dominación hegemónica" 34 desde un giro cultural. Es decir, poniendo el acento en la reflexión sobre las formas de negociación entre los grupos sociales asimétricos y no en la mera imposición de conciencias por parte del grupo dominante.

En este sentido, Martín-Barbero señala que la dominación hegemónica sólo es posible en la medida que el repertorio dominante representa intereses que también reconocen de alguna manera como suyos las clases subalternas (Martín-Barbero, 1998). Desde esta posición, como sostiene Raymond Williams (1980) no se comprende que la dominación hegemónica pueda instalarse de modo pasivo sino más bien desde relaciones que implican resistencia, conflictos, negociaciones.

Es en este marco, que siguiendo a Hall (2010) en el análisis de las formas simbólicas, ideológicamente codificadas y decodificadas por los públicos, importa ver cómo los sujetos invisten de sentido a las imágenes y por ende, el modo en que las representaciones trabajan, se hacen partícipes de la lucha intersubjetiva por la fijación de determinada significación social.

Asimismo, ello configura la noción de representaciones fotográficas como articulación $^{35}$ de formas de ver y dar(se) a ver que proponemos, donde importa atender los modos en que los sujetos actúan las posiciones que demanda la regulación normativa o bien hacen "a medias" y algunos en la negociación presentan resistencias y confrontan esos regímenes de in-visibilidad. Particularmente, en este trabajo, la observación de dichas actuaciones se concentra en el abordaje de la producción fotográfica, tanto desde la consideración de la posición que adoptan los retratados ante la cámara como de los modos de construcción de las imágenes que presentan los fotógrafos en vinculación con condiciones de producción, circulación y recepción. Estas relaciones, si bien cobran relevancia en la aproximación a los actos de fotografiar del Capítulo 6, se plantean como dimensiones que atraviesan todos los capítulos de análisis de fotografías.

\footnotetext{
34 Stuart Hall recalca las diferencias entre dominación ideológica y hegemonía que muchas veces son utilizadas erróneamente como equivalentes. "La "hegemonía", en el sentido de Gramsci, no designa la simple escalada de una clase entera al poder, con su "filosofía" plenamente constituida, sino al proceso por el cual se construye un bloque histórico de fuerzas sociales y se asegura su ascendencia. Entonces, la manera en que nosotros conceptualizamos la relación entre 'ideas dominantes' y 'clases dominantes' se piensa mejor en términos de los procesos de 'dominación hegemónica”' (Hall, 2010: 151).

${ }^{35}$ Grossberg señala desde una comunicación con Hall que la articulación nombra para los estudios culturales "la práctica transformativa o el trabajo de hacer, deshacer y rehacer relaciones y contextos, de establecer nuevas relaciones a partir de viejas relaciones o de no relaciones, de trazar líneas y mapear conexiones (...) Pero la articulación no es una práctica única o singular. Las distintas conexiones tendrán fuerzas diferentes en contextos particulares y deben medirse (...) De hecho, hay tantas prácticas de articulación diferentes como formas hay de relacionamiento(... Pueden entenderse éstos como modos o perfomances de articulación" (Grossberg, 2009: 26).
} 


\section{La RF como imagen anacrónica, acto de imagen o modo de presencia}

Volviendo a las consideraciones sobre la posibilidad de la re-politización de la mirada a través de la imagen, entendemos que ello implica hacer hincapié en su carácter de representación cultural, como también su dimensión agencial comprendida a partir de las diversas instancias de circulación, recepción, consumo y apropiaciones. Es decir atender detenidamente las formas y sentidos que cada imagen vehiculiza a través del tiempo, como así también los modos de "mostración" o "presentación" a partir de los cuales el cuerpo icónico de la imagen interpela a quien la mira en el marco de los procesos de percepción y circulación cultural.

En este sentido, ya a principios del siglo XX, Aby Warburg, el fundador de la llamada Bildwissenschaft o "ciencia de la imagen"36, advertía que la imagen posee la capacidad de "parar" el tiempo en tanto adquiere condición de acto presente en sus instancias de mostración, así como se inviste de un principio activo capaz de generar en la relación inmediata con quien la mira su propia significación (Moxey, 2009; Cangi, 2011).

Esta capacidad es la que le permite a la imagen, más allá de vehiculizar ideologías y funcionar en relación a los intereses para los cuales fue creada, también subvertir esos sentidos atribuidos en su circulación. Es decir, al tiempo que la imagen condensa una densidad histórica-cultural compleja, puede a su vez generar nuevas trayectorias de sentidos desde las diversas instancias de circulación/mostración que la alejan de las motivaciones y expectativas de significación concebidas por el creador.

Del mismo modo, al decir de Didi Huberman, la fotografía también puede plantearse como una imagen "anacrónica", un montaje de "tiempos diversos" que configuran “anacronismos" y que la hacen poseedora de "más memoria y más porvenir que el ser que la mira" (Didi Huberman, 2006: 20; 2009: 32).

\footnotetext{
${ }^{36}$ La Bildwissenschaft indaga el modo en que la imagen adquiere su propia identidad con cierta autonomía frente al texto lingüístico. Trabaja no sólo obras de arte, también imágenes mediáticas, objetos de la cultura popular, prácticas sociales, entre otras y esta amplitud resulta relevante en la reflexión sobre la fotografía. Mayor desarrollo sobre los lineamientos de esta escuela, así como sobre las diferencias e intersecciones con los estudios visuales norteamericanos pueden leerse en las correspondencias entre Boehm y Mitchell y el estado de cuestión realizado por Ana García Varas en el libro Filosofía de la imagen editado por Varas (2011). Por su parte, Warburg particularmente se ocupó de analizar supervivencia de las imágenes, la memoria de éstas; así como las relaciones entre gestualidad, expresión corporal, movimiento, expresividad, simbolismo y arte del Medioevo al Renacimiento. Fanger resalta al respecto que el historiador "demostró cómo durante el período transcurrido entre el 1100 y el 1300 el arte superó la necesidad que de la boca de los personajes salieran pergaminos escritos: las palabras fueron sustituidas por gestos, expresiones faciales (...) el lenguaje visual de la pasión" (Fanger, 2011:10).
} 
Asimismo, esa densa memoria de la imagen está hecha de la re-creación de esquemas de citas, de elementos iconográficos alojados y permanentemente actualizados en la memoria colectiva. Desde allí, estos elementos son re-apropiados y reintroducidos por la imagen en la cadena discursiva, facilitando su reconocimiento desde la recepción. Se trata de un mecanismo re-iterativo, anclado en el proceso de semiosis y de la comunicación, que brinda a la re-presentación fotográfica una potencia y un poder para reactivarse y proliferar después de largos períodos en distintas esferas de la cultura (Cebrelli y Arancibia, 2007, Malosseti Costa, 2001; Barrios, 2014).

De alguna manera, podríamos decir entonces que en la capacidad reproductora y regenerativa de sentidos de la imagen; así como en sus cualidades sensibles inherentes; reside su potencial performativo y su capacidad de pervivencia más allá de la materialidad del lienzo, el metal, el papel, la diapositiva o la pantalla que la hace visible en un presente efímero.

Es a Warburg a quien le debemos gran parte de los estudios sobre esta "vida" de las imágenes sobre la que aquí volvemos. Este influyente historiador del arte centró su exploración en el potencial de la forma en relación al gesto, las emociones a través de las imágenes, haciendo hincapié en la memoria, la supervivencia y la migración de estas formas iconográficas a través de las representaciones a lo largo de la historia (principalmente se conoce su indagación sobre la actualización y re-significación de las fórmulas del pathos del Medioevo en pinturas del Renacimiento ${ }^{37}$. Sin embargo, algunos referentes alemanes plantearon más bien un rodeo ontológico para resaltar este status animado de las imágenes rechazando, a su vez, el modelo lingüístico desde el cual se analizaban las imágenes en la década de 1980. Estos autores, son los que anuncian hacia la década 1990 el "giro icónico" en Alemania (Gottfried Boehm, Horst Bredekamp y Hans Belting). En paralelo, otros referentes en Estados Unidos hablarán también del "giro hacia las imágenes", "giro visual", o "giro pictórico" -según diferentes traducciones- con connotaciones diferentes (W.J.T Mitchell, James Elkins, Keith Moxey) ${ }^{38}$.

En la línea alemana, Gottfried Boehm plantea una visión que privilegia la indagación del carácter ontológico de la imagen por encima de su función política e ideológica. Se intenta responder en primer lugar ¿qué es una imagen?; ¿dónde se encuentra el lugar de la imagen en la experiencia?; ¿cómo funcionan las imágenes en la experiencia? (Varas, 2011).

${ }^{37}$ Línea que puede ser seguida en los estudios de Panofsky, Gombrich, Burucúa, Ginzburg o el mismo Didi Huberman, entre otros.

${ }^{38}$ Por la aparición en paralelo de los planteos, aunque presenten diferencias importantes, se suele llamar a estas escuelas los estudios visuales alemanes y los estudios visuales estadounidenses. 
En este sentido, Horst Bredekamp resalta, entre otros postulados, que el poder de la imagen se encuentra asociada a su forma de "presencia" o "modos de presentación", siendo esta forma la que la define como tal. El autor, que acuñó a principios de los años 2000 el concepto "imagen técnica" para estudiar la importancia de las imágenes científicas en la construcción del conocimiento descartando su concepción como mera ilustración de los contenidos escritos, a la vez desarrolla su teoría sobre los "actos de imagen".

Bredekamp establece tres actos fundamentales que desempeñan imágenes: 1) aquellas que presentan esquemas como estándares de valoración a imitar con el objetivo de influir en el espectador y ejemplifica con cuerpos humanos y gestos heroicos; 2) las imágenes "sustitutivas" que ocupan el lugar del objeto al que refieren y le otorgan nueva presencia y nueva vida, como las imágenes religiosas; y 3) las imágenes que poseen una fuerza “intrínseca” basada en la fuerza de la forma y las propiedades visuales (Bredekamp, 2010).

Esta teoría nos advierte sobre la necesidad de reflexionar acerca del modo en que las imágenes fotográficas desde sus aspectos formales y físicos interpelan al espectador. Si bien los primeros dos tipos de actos se aproximan a algunas ideas desarrolladas por otros autores, el tercer tipo de acto convoca a una discusión detenida en los atributos intrínsecos de la imagen. Es decir, la fuerza de la forma, la figura, el color hecho cuerpo en la materialidad la imagen, aspectos cruciales que permiten a quien la mira tomar conciencia de sí. Aunque la mirada enfocada en este tipo de acto tiene limitaciones y se presenta como una posición ontológica radical en tanto deja de lado las relaciones de lo visual con los regímenes de invisibilidad y las prácticas culturales específicas ${ }^{39}$, a su vez posibilita complejizar nuestra mirada sobre la cualidad fáctica y expresiva de las imágenes.

Sin desatender otros niveles de lectura, esta perspectiva convoca a comprender que más allá de los significados ideológicos diversos devenidos de tiempos precedentes que la configuración de la imagen entrama en tanto construcción social, la fotografía en este caso, posee además la capacidad de afectarnos desde su atractivo formal, técnico y medial, en términos de Belting, construyendo desde allí también su dimensión de agencia.

\footnotetext{
${ }^{39}$ La crítica hacia esta perspectiva la desarrolla Lumbreras (2010), no sin antes señalar su pertinencia a los debates de la época en tanto el enfoque se desarrolla en reacción a los modelos lingüísticos imperantes aplicados al análisis de las imágenes así como a los paradigmas culturalistas de interpretación de los sentidos ideológicos, al entender que estos enfoques descuidaron la especificidad de las imágenes. Sin embargo, como señala Lumbreras (2010) la atención puesta en la indagación las propiedades físicas de las imágenes han dejado de lado el estudio de su condición de representaciones y su función social y política. Por ello, la alternativa es apostar por una mirada integradora que responda a la especificad que definen a las imágenes como tales sin desatender las prácticas socio-culturales en las que se insertan y las relaciones de poder que las atraviesan. La apertura estará en parte planteada en la corriente de los estudios visuales norteamericanos.
} 
Esto permite observar, como señala Moxey que "los artefactos visuales están incrustados en medios y que unos no pueden ser estudiados sin los otros" (Moxey, 2009: 9). Esta reflexión retomada por la referente de los estudios visuales estadounidenses de lo que Hans Belting dio en llamar la "antropología de la imagen" centra el análisis en el MedioImagen-Cuerpo y refiere al medio como metáfora del cuerpo humano. En relación a ello cita Moxey de Belting: “"así como los artefactos visuales están inscriptos en los medios, las imágenes internas están inscriptas en el cuerpo humano'. El medio es pues una figura para la agencia de los objetos visuales que son concebidos como algo más que representaciones" (Moxey, 2009: 10).

Sin embargo, cabe preguntarse aquí ¿hasta qué punto este medio o cuerpo de las imágenes no se presenta como el efecto de regímenes de verdad que sostienen diversas relaciones de saber/poder en el mirar y el ver?

Para retomar esta pregunta más adelante, cabe acotar que a diferencia de Bredekamp a quien algunos autores consideran el más formalista en la línea de la Bildwissenschaft por la trascendencia otorgada a los modos de "presencia" de la imagen sobre otras dimensiones ${ }^{40}$, las lecturas de Belting, y en particular las realizadas sobre fotografía, que hacen hincapié en las relaciones entre la imagen, el medio y la mirada; entre productor, espectador, mirada y mundo, nos habilitan, en parte, a resituar el análisis en el ámbito de la cultura. Ello sin desatender el reclamo que la indagación de las imágenes no puede ser reducida sólo a códigos y significación.

En este sentido, este referente señala que "la fotografía reproduce la mirada que lanzamos al mundo" y en esa línea la foto se plantea como "un medio entre miradas", así como somos los propios sujetos los que "damos animación al medio ${ }^{41}$ para recuperar de él nuestras propias imágenes (Belting, 2007: 276 y 295).

De este modo, el abordaje del estatus animado de las imágenes - que en la indagación de Belting diferencia y relaciona dos tipos de imágenes: las internas, de la imaginación, y las externas o materiales- resulta relevante para pensar el carácter performancial y agencial de la fotografía de prácticas religiosas aunque la autonomía de su agencia es relativa porque como indica Moxey (2009) la animación de las imágenes, su capacidad de afectación, deriva de la relación que se establece con quienes la miramos. Entonces el análisis experimenta un desplazamiento del foco centrado en la imagen y su materialidad a las relaciones de esta con

\footnotetext{
${ }^{40}$ Así puede leerse en la crítica de Lumbreras (2010).

41 El medio aquí no se reduce a medios masivos sino refiere al artefacto (técnico- creativo) material, soporte, cuerpo en la que se plasma la forma de la imagen y que posibilita la relación de su mundo de formas, signos y valores con la del espectador.
} 
la mirada del espectador, en tanto sujeto y actor social, y el proceso intersubjetivo que ello implica. El reconocimiento del sujeto como parte activa en el proceso de semiosis abre la discusión en torno a la imagen hacia una dimensión antropológica y comunicacional significativa. De este modo, su comprensión no sólo depende de la valoración del estatus ontológico sino también de su interacción con el hombre en su entorno socio-cultural.

De hecho, esto nos lleva a responder a la interrogación que, en tanto el mirar y el ver son prácticas culturales, la apreciación/disposición de la forma, el cuerpo, el medio de las imágenes está condicionada necesariamente por un régimen representacional e iconográfico, una codificación cultural que se actualiza y regula en los modos de percepción. Incluso cuando nos referimos al nivel denotativo del análisis de la imagen, como bien aclara Hall, si bien este estado refiere al sentido literal del signo y se nos presenta como naturalizado "no es natural" (Hall, 2010); en tanto la perspectiva resitúa su pregunta en la relación entre el espectador y la imagen aparecen también los interrogantes sobre las convenciones, las reglas y los regímenes históricos que median este vínculo.

Por su parte, el planteo de Moxey realiza una nueva apertura que acerca algunos postulados alemanes, a pesar de las dis-continuidades, al de los estudios visuales estadounidenses. En este sentido, resulta interesante el acento puesto por Mitchell y Moxey en el análisis de la imagen como presentación de la Bildwissenschaft pero otorgándole centralidad al concepto de visualidad que pone en relación la imagen, con las instituciones, el discurso y las relaciones de poder. Además de la pregunta insistente en ¿qué es la imagen?, Mitchell avanzará hacia el cuestionamiento: ¿para qué sirven y qué quieren las imágenes? (Lumbreras, 2010).

Entonces, lo visual no refiere solamente al proceso fisiológico de la visión sino más bien a la construcción de lo social desde la mirada. Se entiende esa visualidad como el resultado de una compleja trama de prácticas institucionales, relaciones históricas y de poder que se intersectan en los actos de ver y dar(se) a ver. Estos actos son explorados bajo los conceptos de imagen-acto e imagen identidad que se desarrollan en el capítulo siguiente.

Desde este punto de vista, volverá a primar la necesidad de entender a las imágenes en sus especificidades en la vida de la cultura; es decir, importará más allá de sus formas y significados intrínsecos o inmanentes los significados que ellas adquieren en el horizonte más amplio de la producción y reproducción cultural.

En este sentido, retomando la demanda del giro icónico de no circunscribir el análisis de las imágenes sólo al modelo textual lingüístico planteado por los historiadores del arte de los Estudios Visuales, Nicholas Mirzoeff (2003) vinculado a los estudios de los media y la 
crítica cultural se ubicará aún más cercano a nuestra pretensión de un planteo articulador de visiones que definimos mejor al final de este capítulo. Este autor también insistirá en la reivindicación de la visualidad en el campo de la denominada Cultura Visual atravesada por cambios tecnológicos y nuevos medios. En este marco, resaltará el modo en que la vida contemporánea "se desarrolla en una pantalla" y la experiencia humana se plantea "más visual y está más visualizada que antes" pero que esta mediación visual de la experiencia y la imaginería del ver deben ser estudiadas "como puntos de intersección de la visibilidad con el poder social" (Mirzoeff, 2003:17-18 y189).

El interrogante de Mirzoeff sobre cómo y por qué los medios visuales, así como las tecnologías visuales ${ }^{42}$, entre ellos la fotografía, el cine, la televisión, se han convertido en algo tan importante en la vida cotidiana contemporánea, es de vital importancia en nuestro abordaje sobre la participación de las imágenes en la producción/propagación de las prácticas religiosas en torno al Gaucho Gil. Ello, en tanto consideramos que esta devoción tienen un componente predominantemente visual, donde la iconicidad móvil y performática que gana los cuerpos, los territorios y las pantallas, ocupa un rol trascendente en su proliferación y visibilización más allá de las fronteras provinciales.

Es en este sentido que entendemos, como veremos más adelante, que lo visual no es un elemento más en el caso de análisis, sino que se configura como un entretejido central; lo visual aquí "se pone entredicho, se debate y se transforma como un lugar desafiante de interacción social" (Mirzoeff, 2003: 19) desde donde se definen formas y modos de marcación de clase e identidades sociales.

Mirzoeff además estará muy vinculado a los escritos sobre este campo de Jessica Evans y Stuart Hall quienes insistirán, retomando las preocupaciones de los estudios culturales y tomando algunos textos centrales acerca del análisis de las imágenes, sobre el modo en que el campo subjetivo de la visión "es en sí mismo producido a través de la diferencia sexual, racial y de género, y cómo el mirar y el ver, en tanto que prácticas culturales, están siempre construidas en el campo de la sexualidad, el género y la raza" (Evans y Hall, 1999: 314). En torno a esta tesis también gira buena parte de los planteos realizados por Caggiano (2012).

En resumen, esta revisión nos permite entender que las re-presentaciones visuales, como las fotográficas que nos ocupan, no resultan como un "subproducto" de la realidad

\footnotetext{
${ }^{42}$ La tecnología visual es entendida por Mirzoeff como "cualquier forma de aparato diseñado ya sea para ser observado o para aumentar la visión natural desde la pintura al óleo hasta la televisión o internet" (Mirzoeff, 2003: 19).
} 
social sino que la construyen activamente. En este sentido, la re-presentación fotográfica adquiere, al decir de Hall, un "rol activo de seleccionar y presentar, de estructurar y moldear: no meramente la transmisión de un significado ya existente, sino la labor más activa de hacer que las cosas signifiquen" (Hall, 2010: 163).

Las dimensiones de la imagen teorizadas hasta aquí son retomadas a lo largo de la segunda parte de la tesis. Así, estos instrumentos teóricos nos sirven específicamente para indagar en el Capítulo 3 el carácter iconográfico y fotogénico de la devoción al Gaucho Gil, donde empieza a explorase en la "supervivencia" de las imágenes, en los términos de Warburg recuperada por Didi Huberman, sus migraciones y re-significaciones a través de distintos formatos y cuerpos visuales. Ello enmarcado en un escenario de diversificación religiosa en el país y de producción massmediática de la cultura, lo que nos conduce a referenciar junto a los exponentes de los estudios visuales-culturales también reflexiones sobre la comunicación y la cultura, la religiosidad y sus vinculaciones con otros campos. Asimismo, esa idea de "supervivencia" warburiana cobra fuerza en las discusiones del Capitulo 5 sobre las relaciones entre las imágenes del Gaucho Gil creada por algunos autores específicos (Faccioli y López), las operaciones de anclaje y actualización en la memoria colectiva, las citas y las apropiaciones. También estos escritos abonan la exploración sobre las formas del melodrama que trata el Capítulo 6 a partir del abordaje de las fotografías de Faccioli y Rusconi.

\section{La RF como un actante con un doble poder o potencial performativo}

La problemática de la productividad de la imagen y su capacidad performativa, que aparece como constante en las discusiones expuestas, hace retornar la reflexión a la concepción de representación propuesta por Marin (2009). Para el autor re-presentar desde el prefijo re alude en primera instancia a la noción de sustitución, el poder de la imagen de volver a presentar lo ausente; o en términos peircianos señala un signo que está por algo para alguien en algún aspecto o capacidad (Peirce, 1897). Sin embargo, representar también implica un segundo efecto que Marin llama "efecto de sujeto" y refiere al poder de la representación de exhibir su propia presencia y construir con ello al sujeto que la mira; de redoblar, intensificar la presencia; de instituir, autorizar y legitimar formas y modos de ser, de percibir y de actuar. Aquí más que las relaciones de semejanza o contigüidad física con su referente, importa la capacidad del signo de adquirir una forma simbólica.

Retomando esta noción, en definitiva las inquietudes de este trabajo se orientan a 
desentrañar ese "doble efecto" o "doble poder" de la re-presentación fotográfica vinculada a las prácticas religiosas; a explorar sus alcances y limitaciones desde la trama de la visualidad fotográfica los modos en que el sistema de representación instrumenta mecanismos de reproducción de creencias. Para ello resulta necesario atender el modo en que las instituciones, los sujetos se crean representaciones para sí e invisten de sentidos a las fotografías; y a la inversa, cómo estas representaciones le otorgan sentido y legitimidad a las percepciones y acciones de los sujetos por un lado y de las instituciones por el otro.

El segundo poder de la representación al que se refiere Marin nos advierte también acerca la potencia performativa que pueden adquirir determinadas imágenes sobre la base de ciertas prácticas institucionales y relaciones históricas concretas. Esto ser relaciona con lo que sostiene Mitchell (2003) acerca de la capacidad que tienen algunas imágenes de imitar la vida humana, de proliferar y reproducirse, así como la facultad que tienen de afectar y "controlar la vida de sus creadores" en el sentido de que pueden impactar sobre las prácticas y creencias.

Este segundo poder remite a la instancia en que las representaciones están "en situación de ejercer una acción sobre algo o alguien; no actuar o hacer, sino tener la potencia" (Marin, 2009: 4), es decir, tener la posibilidad de hacer-hacer. Sin embargo, esta potencia requiere ser comprendida desde los contextos de producción y uso, a la vez desde los lugares donde la mirada y las imágenes configuran construcciones simbólicas, sistemas de códigos, prácticas de ver y mostrar, pero también de visibilizar e invisibilizar (Mitchell, 2003; Guasch, 2003).

Por otro lado, la noción de performatividad permite atender la capacidad de agencia de las imágenes, lo que Butler entiende como "una expectativa que termina produciendo el fenómeno mismo que anticipa" (Butler, 2001: 15). Esta visión profundiza las indagaciones sobre la exploración del lenguaje y su "potencial performativo" que propusiera John Austin y reelaborara Jacques Derrida (1972) desde el posestructuralismo. Este potencial remite a una capacidad que adquiere fuerza normativa en la cita, la re-iteración, que no sólo reproduce sino también inventa (Derrida, 1972). Esto le permite no solo formatear sino también "producir" relacionalmente los cuerpos, las identidades y las memorias, en definitiva construir la "realidad" accionando en, sobre y con ella.

En el caso de las fotos de prácticas religiosas o de sacralización, como las de la festividad del Gaucho Gil, pensar su dimensión performativa implica observar cómo en tanto re-presentaciones, éstas portan conceptos y valores específicos sobre la cultura ritual o religiosa y retóricas identitarias y el modo en que inciden en las percepciones, la 
inteligibilidad y en las acciones de los sujetos/espectadores, en interacción con ellos en instancias de circulación también desde su dimensión de mostración/ presentación (Cebrelli y Arancibia: 2007; Barrios: 2014).

De este modo, la fotografía reclama ser entendida desde su doble dimensión de representación-presentación, atendiendo tanto a sus sentidos ideológicos como su especificidad icónica sensible y sus relaciones con aquellos que la invisten de sentido. Al respecto, resulta relevante recalcar que esa doble consideración sólo es posible por la intervención ideológica del productor y sus condiciones histórico-sociales, así como por el encuentro de la imagen en tanto "objeto visual" con un espectador activo que actualiza, completa y re-significa los sentidos propuestos por la re-presentación y quienes la manipulan dentro de los marcos regulatorios de lo visual y lo social-cultural.

Desde los estudios culturales, esto se puede relacionar la noción de representación a la que refiere Hall (2010). El autor señala que aunque las representaciones "trabajen" por la fijación de los significados, siempre éstas se plantean como el tejido de una trama que no se cierra en un significado dado, sino que se regenera en la propia actividad semióticadiscursiva. En otras palabras, la representación fotográfica no se manifiesta ya como un imagen con poder que actúa sino que en su actuación re-iterada "se hace poder en virtud de su persistencia e inestabilidad" (Butler, 2001:28).

Vale advertir también, y más aún cuando de imágenes religiosas o vinculadas al campo religioso se trata, que ese "objeto visual" 43 al que referimos, como señala Jean Marie Schaeffer, no es "algo frente a lo cual estamos, sino un actante, una entidad con la cual interactuamos" (Shaeffer, 2012: 64). De allí deviene la concepción agencial defendida por Gell desde la cual estos "objetos" pueden ser entendidos más bien como entidades con vida que se parecen a las personas. Esta teoría es la retomada por Schaeffer y también por Mitchell, entre otros; y resulta productiva en esta tesis para abordar cómo ciertas iconografías alojadas, actualizadas y reinsertadas en el mundo material de las imágenes circulantes -como las diferentes versiones del propio Antonio Gil- activan determinadas propiedades y funciones de las mismas desde los usos y las miradas particulares que realizan sobre y con ellas los

\footnotetext{
43 El término objeto se utiliza entre comillas para advertir, siguiendo a Schaeffer y sus reflexiones específicamente sobre el "objeto estético" en los debates vinculados al arte, que es preferible plantear el problema estético de las imágenes en tanto hecho y no objeto; noción que permite dar cuenta del carácter procesual, en este caso de "lo fotográfico", evitando el "rodeo ontologizante" desde el cual se ha concebido lo estético como una propiedad inherente al objeto/obra; cuando en realidad "no existe una propiedad estética inherente a la obra" se construye como una dimensión de relacional entre la obra y las conductas del creadorespectador" (Schaeffer, 2012: 64)
} 
fotógrafos, devotos, entre otros productores-consumidores de imágenes en un contexto también específico; tal como se explora en el último apartado del Capítulo 5.

Llegados a este punto, podemos resumir que esa potencialidad que la re-presentación fotográfica posee de producir la realidad de modo relacional $y$, a la vez generar el efecto primario de concedernos una imagen "fiel" de lo real, fundamenta la histórica aspiración y esfuerzo ejercido por determinados gobiernos, la ciencia, los aparatos ideológicos del Estado, por apropiársela y ponerla a circular en función de sus intereses. Por ello, la historia de la

fotografía y sus poderes es también una historia del poder, o más bien, de su inserción en las relaciones de poder que estructuran la interdiscursividad del campo del conocimiento. Tal como señala Tagg, incluso esa fuerza constatativa que se le otorga a la foto es el resultado de un proceso social y semiótico complejo "que implica técnicas, procedimientos definidos, instituciones sociales específicas, es decir relaciones de poder" (Tagg, 1988: 11). Se trata de relaciones que en este trabajo buscamos atender en relación a un caso específico para comprender cómo esos "poderes" atribuidos a las imágenes se actualizan, son agenciadas y reproducidas por la sociedad contemporánea en base a prácticas institucionales y a partir de procesos socio-semióticos específicos como los que nos ocupan.

\section{La RF como imagen-acto e imagen-identidad}

La reflexión acerca de la re-producción o la subversión de los sentidos desde las imágenes también implica focalizar la mirada en los procesos de producción y circulación específicos, observar los usos diversos que los sujetos realizan de las re-presentaciones según la posición que adoptan en cada instancia de producción de sentidos, siempre actuando en respuesta, rechazo, acuerdo, negación o desconocimiento de los modelos representación vigentes, es decir en relación a los regímenes que gobiernan las formas de in-visibilidad.

Esto, a su vez, lleva a reflexionar sobre las múltiples posiciones que los sujetos adoptan para percibir y percibirse, ver y dar(se) a ver. Ello deviene pensar en que estos procesos están anclados a la praxis social, lo que exige un análisis sobre "la contingencia del presente", como dice Hall, que la realidad no está predeterminada y "que siempre puede ser transformada" (Hall, 2010: 10-14) Por otro lado, esta cuestión nos remite a la advertencia de 
Hall de que la práctica no debe pensarse "como transparentemente intencional" y que los quiebres/transformaciones son posibles desde la articulación entre práctica y estructura ${ }^{44}$.

En esta línea, la propuesta de abordaje realiza una nueva apertura hacia el análisis de la producción fotográfica desde de los propios actos de ver y dar(se) a ver. Desde el ámbito analítico concreto nos ocuparemos sobre el modo en que se tejen las negociaciones, las relaciones de poder y dominación, las formas de ocultamiento y visibilización desde los propios actos de producción fotográfica. En esta dirección se orientan los esfuerzos de reflexión articuladas la observación de los actos fotográficos en la festividad del Gaucho Gil que se desarrolla en el Capítulo 6.

Como punto de partida, entendemos que la re-presentación fotográfica se configura como un espacio de intersecciones no exento de tensiones, que si bien en tanto proceso de construcción de las imágenes apunta a suturar las diferencias adscriptas a un intento de unidad de sentido, por su naturaleza de "texto abierto" la imagen siempre alberga la emergencia de significados diversos.

Ello nos revela a la producción fotográfica como "articulación", lugar de cruce de experiencias y posiciones intersubjetivas, de diálogo, donde también juegan un rol central en definición de "lo fotográfico" las formas de presencia del cuerpo, el gesto de fotógrafos y fotografiados, sus cualidades afectivas, poéticas y estéticas atravesadas por intereses propios y ajenos y vinculadas a un entorno también concreto como componentes centrales del proceso semiótico-comunicativo.

Desde acá es posible reflexionar, en primer lugar, sobre la noción de "imagen acto" que, retomando el pensamiento de Charles Peirce, Phillippe Dubois trabaja en su texto sobre el acto fotográfico. Allí insiste en la trascendencia del análisis del signo fotográfico "no sólo teniendo en cuenta el mensaje como tal sino también y sobre todo el modo de producción del mismo". Al respecto dice el autor: "Con Peirce uno se percata de que no es posible definir el signo fotográfico fuera de sus circunstancias: no es posible pensar la fotografía fuera de su inscripción referencial y su eficacia pragmática” (Dubois, 2008: 61).

Estas reflexiones invitan a la realización una "lectura performancial". Es decir, entender que el significado y la interpretación de la imagen dependen de su performance, siendo la contextualización el proceso mediante el cual los performers (fotógrafos y fotografiados) incluyen sus marcas para que las imágenes que surgen tengan un determinado

\footnotetext{
${ }^{44}$ De allí cita a Marx a través de Althusser: "nosotros hacemos la historia, pero sobre la base de condiciones precedentes que no son producto nuestro. La práctica es la manera como una estructura es reproducida activamente" (Hall, 2010: 202).
} 
sentido para el público en el incesante devenir del proceso semiótico comunicativo.

Para Sánchez Carretero la "lectura performancial" del fenómeno fotográfico supone hacer hincapié en el acto de hacer fotos, así como de mostrarlas, guardarlas o utilizarlas. La autora distingue al menos tres momentos de la performance fotográfica: "las performances de producción: los momentos en que se toman las fotos. Las de recepción: cuando se mira la foto por primera vez y hasta que llega a destino. Así como la performance estática, que consiste en la decoración de la casa con fotos familiares, en paredes, vitrinas" (Sánchez Carretero, 2005: 213).

Particularmente, en este apartado nos interesa el primer momento donde se conjugamos los conceptos de "imagen acto" e "imagen identidad" que desarrollamos siguiendo a Dubois y Buxo i Rey para explorar las prácticas de fotografiar en la festividad del Gaucho Gil que se expone en el Capítulo 6.

El tipo de análisis propuesto por Sánchez Carretero nos remite, entre otros, por un lado a los estudios de Dell Hymes con el desarrollo del concepto de competencia comunicativa (1972), a partir del cual la construcción del sentido no puede ser abordada sólo teniendo en cuenta los significados explícitos o literales de lo que se dice sino también lo que se quiere decir, teniendo en cuenta lo implícito y las inferencias culturales, ideológicas y psicológicas contenidas en el uso del lenguaje en un momento dado. Por otro lado, aparece la referencia obligada del aporte de John Austin (1982) quien sostiene que la emisión de ciertos enunciados no sólo implica hablar o comunicar sino también realizar una acción. Cabe señalar que esta teoría de los actos de habla del filósofo del lenguaje también está en la base de la valoración del carácter presentativo de las imágenes que exploran los estudios visuales con sus diversos matices; así como particularmente los "actos de imagen" propuesta por Bredekamp; sin embargo, la propuesta de Sánchez Carretero plantea un mayor énfasis en la consideración del rol de los productores y receptores de fotos en relación al contexto, más que en la cualidad "diferencial" de la imagen frente al texto lingüístico a partir del cual los referentes del giro icónico y visual indagan a la imagen como agente vivo.

Desde esta "lectura performancial", la acción de fotografiar la comprendemos como performance en la medida que, al decir de Buxó i Rey en su relectura de Guattari y Deleuze, la cámara se presenta como un "tercer ojo" al que el fotografiado le devuelve la mirada, entrando y saliendo del discurso con su cuerpo y sus gestos en la plena manifestación de diversas sensaciones, afecciones y conceptos. "No se trata sólo de un acto referencial sino que significa por sí mismo" (Buxó i Rey, 1998: 183). 
En otras palabras, al decir de Green y Lowry, la imagen cobra existencia y sentido al actuarse. Al respecto, estos autores enfatizan a la acción como constitutiva y definitoria de las imágenes fotográficas: "Las fotografías no son indiciales sólo porque la luz se registre en un instante sobre la porción de película fotosensible sino, primero y ante todo porque se hicieron" (Green y Lowry, 2007:50)

En este sentido, la foto más allá del registro en sí habla del testigo que captura el acontecimiento, de la mirada construida y ello nos remite ineludiblemente a la presencia del autor que al señalar, per-forma lo que ocurre. La afirmación de esa presencia nos enseña que más allá de ese doble rastro de lo real que alberga la fotografía -la huella de la escena de un acontecimiento y el gesto indicador del fotógrafo que declara que el hecho se está produciendo (Green y Lowry, 2007)- siempre hay alguien que opera e interviene ideológicamente para lograr ese "efecto de verdad" (Barthes, 2004).

Es decir que más allá de lo azaroso, conviven y formatean la fotografía los marcos mentales en los cuales los intervinientes se basan para producir y proyectar una determinada imagen y no otra de la realidad. Esto refiere a "los lenguajes, los conceptos, las categorías, la imaginería del pensamiento y los sistemas de representación que las diferentes clases y grupos sociales utilizan para (...) hacer entendible la manera en que funciona la sociedad" (Hall, 2010:134).

Este proceso remite al caso del fotógrafo que través del recorte fotográfico proyecta, en la medida de lo que el tiempo- espacio y lo efímero del acontecimiento lo permite y sobre condiciones precedentes que estructuran las codificaciones posibles, su intencionalidad, su modo de ver sobre lo representado; pero también del fotografiado que puede incidir, dependiendo de las circunstancias, y por ende intervenir en la escena fotografiada.

De esta manera, el producto fotográfico se presenta como un lugar de “articulación/desarticulación discursiva” (Hall, 2010; Groosberg, 2009 ), una trama que se configura atravesada por la lucha y/o la negociación de posiciones particulares, tendencias estéticas, intereses económicos e ideológicos de los medios para los cuales el fotógrafo cubre el evento o bien por intenciones de búsquedas personales y también se ve condicionada por las relaciones previamente establecidas por el fotógrafo en el espacio compartido con los sujetos retratados y las diversas condiciones espacio-ambientales y temporales en que ellos se insertan.

Ello da cuenta del proceso de articulación parcial, nunca definitiva o suturada (Hall, 2010) y siempre dialógica (Bajtín, 1982), atravesada por las subjetividades en cruce que el 
acto fotográfico supone. Hablamos de un diálogo que se concibe en términos de Bajtín como "inconcluso", que es la base de la generación y reproducción del sentido.

Este recorrido en esta instancia de performance convoca también a discutir la noción de "imagen identidad”. Este concepto lo desarrolla Buxó i Rey, quien convoca a entender que "la gente no simplemente se deja tomar una foto, sino que actúa activa y retóricamente construyendo su imagen". Que los sujetos plantean un "uso simbólico" de su cuerpo a través de sus formas de exhibición, presentación, escenificación de un “yo cultural”. Se plantea así una relación entre la hexis corporal y el habitus abordado por Bourdieu (2004), como aquellas formas simbólicas del cuerpo que construyen vínculos entre el individuo y lo social y a la inversa en cuyo marco la fotografía plantea la situación de conciencia del propio cuerpo que se muestra al otro.

Entonces, la dimensión identitaria se activa en el acto fotográfico (imagen-acto) al tiempo no sólo del ejercicio de capturar de determinada forma y no otra y con ello clasificar, catalogar a lo fotografiado en relación con ciertos esquemas reguladores identitarios, a su vez influenciado por las limitaciones de su técnica y los regímenes de visibilidad establecidos, sino también al tiempo que el fotografiado se imagina y se crea así mismo.

La idea de proyección identitaria es desarrollada por Judith Butler quien la relaciona como un proceso en términos de "morfología imaginaria" que no remite a "una operación presocial o pre-simbólica, sino que se trata de una operación orquestada mediante esquemas reguladores que producen posibilidades inteligibles y morfológicas” (Butler, 2002: 36).

Esa noción de esquemas reguladores evidencia que sería iluso pensar que existe en esa participación del acto de concepción de la imagen por parte tanto de fotógrafos y fotografiados algo puramente o solamente creativo sino que también responde a una lógica recreativa y re-productiva de normas en la que la configuración y adscripción a ciertos rasgos iconográficos se asienta.

Ello da cuenta de una articulación de la práctica fotográfica con una estructura de condiciones dadas que habilitan en un momento también determinado el repertorio imaginario disponible, basada en elementos y rasgos compartidos, del cual las personas se valen para significar su realidad y la realidad de los otros a través de la imagen, el cuerpo, las prácticas y las re-presentaciones. 


\title{
CAPÍTULO 2:
}

\section{Debates y posiciones teórico - metodológicos: fotografía, identidades y religiosidad}

\begin{abstract}
"La fotografia como tal carece de identidad. Su posición como tecnología varía con las relaciones de poder que la impregnan (...) Su función como modo de producción cultural está vinculado a unas condiciones de existencia definidas, y sus productos son significativos y legibles dentro de usos especificos que se les dan"
\end{abstract}

John Tagg, El peso de la representación

Las relaciones entre las fotografías y las identidades están asociadas a las valoraciones y posiciones que los sujetos que las manipulan adoptan en la cadena de producción de sentidos. Sin embargo, vale señalar que la vinculación de la fotografía con la noción de identidades puede definirse a su vez en dos planos: por un lado, aquella dimensión que remite a lo que algunos autores denominan las "identidades de la fotografía" (Tagg, 2005) y que refiere a las "categorías" tipológicas, "géneros" y "subgéneros" (Del Boca, 2009) que se construyen teórica y conceptualmente sobre la base de las cualidades y atributos de las imágenes y su modo de vinculación con lo real a los fines de clasificarlas, ordenarlas y sobre todo interpretarlas; por otro lado, está la dimensión que refiere los modos en que la fotografía textualiza y construye y moviliza identidades sociales diversas desde lo visual .

Ambas dimensiones identitarias, si bien están estrechamente ligadas desde su condicionamiento mutuo en los intentos de definición, son planos distintos que conviene diferenciar para continuar con la exposición.

En lo referente al primer plano, como hemos visto en el capítulo precedente, varios autores han definido por lo menos dos macro-categorías: la foto documental -como testimonio objetivo- y el artefacto cultural o la foto artística -como imagen intervenida o manipulada-. De allí se desprenden diversas sub-categorías que varían según la valoración de los autores. A esas categorías más o menos consensuadas en las nominaciones dentro de las investigaciones sobre fotografía -aunque también profundamente discutidas cuando se insiste en una división rígida - se le suman otras clasificaciones que buscan identificar en el caso particular de cada fotografía el asunto y los anclajes de localización a los que remiten las representaciones. 
Por su parte, las identidades sociales que se construyen desde lo visual involucran actos performativos ceñidos a múltiples puntos de vistas que los sujetos adoptan para percibir y percibirse, ver y dar(se) a ver, e intentar fijar algún sentido de lo vivido en las imágenes. A su vez, estos actos se insertan en complejos procesos semiótico-discursivos atravesados por condiciones de inteligibilidad, regímenes de visibilidad (ocultamiento) y enunciación que los dispositivos de poder operantes suponen y actualizan.

Ello da cuenta que las fotografías, en su polifacética vida social, son definidas a partir de valoraciones adheridas al lenguaje que varían según el contexto, movilizan sentidos y afectan los modos de concepción de las personas de diferente modo según las situaciones, las condiciones de las prácticas socioculturales, discursivas e institucionales en las que se insertan.

Partiendo de estos supuestos, este capítulo pone en discusión la atribución de dimensiones identitarias fijas e inalterables a las imágenes fotográficas del Gaucho Gil, sobre todo atendiendo a su movilidad por diferentes contextos. Si bien, desde algunos espacios locales, provinciales e incluso nacionales de difusión hay consenso en concebir a la mayoría de estas imágenes como "documentos visuales" de la "religiosidad [popular]" "correntina y/o argentina", esa triple pertenencia, anclada en una identificación de género o tipología fotográfica, su asunto y localización geográfica, no puede más que entenderse como una construcción "en proceso". Es decir, hablamos de pertenencias que pueden ser sometidas a alteraciones, al reforzamiento de otras dimensiones y marcas de identidad en/ desde las fotografías que se van definiendo, provisoriamente y hasta de forma solapada, en el tránsito de las imágenes por diferentes instancias socio-discursivas de producción y reconocimiento.

En este sentido, los apartados que siguen abren preguntas sobre las categorías de las fotografías que indagamos, comprendidas como documentos, huellas de memoria, o formas de arte; asimismo debate sobre la provisoriedad de las clasificaciones que parten de las vinculaciones de estas imágenes con la noción de religiosidad [popular] y su anclaje únicamente al territorio correntino y/o argentino.

En este sentido, a continuación se establecen algunas líneas de lectura para pensar las fotografías del Gaucho Gil desde el ámbito de los estudios de la comunicación y la cultura. Particularmente se retoman discusiones sobre el carácter fragmentario y dilemático de la fotografía, su relación con el campo religioso heterogeneizado y las tensiones de lo local y lo global en la cultura contemporánea. 


\section{Las identidades y la RF del Gaucho Gil: relaciones, anclajes, tensiones}

¿De qué hablamos cuando hablamos de re-presentaciones fotográficas del Gaucho Gil? Resulta necesario sentar posición respecto a esta cuestión antes de discutir las diferentes dimensiones identitarias de las fotografías. No hablamos de fotos del Gaucho Gil en tanto personaje retratado, pues, a pesar de que entre algunos santuarios y espacios virtuales de rememoración del "santo" circula una imagen que se cree le fue tomada, los datos históricos animan a desestimar la hipótesis de la presencia de una fotografía entendida como "prueba" o “evidencia” de la existencia de Gil. Al respecto, vale señalar que entre 1840-1870 - época de vida de Antonio Mamerto Gil Núñez, según una de las versiones de las leyendas circulantesel daguerrotipo llega a Corrientes para retratar a familias ilustres y registrar las obras del "progreso". Incluso hasta principios de 1900 la fotografía obtenida en la provincia habría estado focalizada en la captura de paisajes, vistas urbanas y retratos de personajes de la política, la iglesia y la elite provincial (Palma, 1959); o al menos son éstas imágenes que en la actualidad pueden visibilizarse en archivos, documentos históricos y postales. Entre ellas, se cuentan escasas imágenes de los denominados "tipos sociales", sobre todo tomadas en la ciudad capital de provincia por fotógrafos viajeros ${ }^{45}$. Entre estos datos, básicamente basados en las restricciones del acceso a la fotografía por parte de los sectores populares, se pone en duda que la imagen circulante corresponda a un registro de Antonio Gil.

Más allá que se podría seguir discutiendo sobre la "veracidad" del famoso retrato y sobre los intereses e implicancias de la construcción de esa foto-verdad y de la creencia en la imagen como prueba -algunos aspectos que retomaremos más adelante-, en esta tesis cuando hablamos de re-presentaciones fotográficas del Gaucho Gil referimos a imágenes del "mundo" del Gaucho Gil creado por fotógrafos, artistas visuales; así como re-creado y por fieles, simpatizantes, seguidores a través de diversas formas icónicas-indiciales y simbólicas de representación.

En ese "mundo", el famoso retrato de Gil, es solo una de las tantas imágenes que cobran sentido para nosotros en tanto configuran "acontecimientos visuales"; es decir imágenes que ni siquiera se definen por el medio o su veracidad, restrictivamente, sino por el tipo de "interacción que establece con el espectador" (Mirzoeff, 20013: 34). Estas imágenes configuran discursos visuales que se tejen y destejen en la construcción de la mirada, entre las prácticas y los discursos heteróclitos de la cultura contemporánea, que circulan y atraviesan

\footnotetext{
${ }^{45}$ Sobre el contexto de inserción de la fotografía en la provincia de Corrientes y las fotográficas in-visibilizadas en el siglo XX, ver Capítulo 4.
} 
campos imaginarios heterogéneos. La noción de "mundo" remite a lo que Camblong define, siguiendo a Sloterdijk (2004), como “el término que designa 'no todo lo que es el caso', sino: todo lo que puede ser contenido por una forma o por una frontera conocida" (Camblong, 2014: 2).

Hablamos de ese mundo registrado, y a su vez, recortado, seleccionado, diseccionado por la fotografía. Justamente, la evidencia de estas operaciones "no inocentes", atravesadas por posiciones intersubjetivas, que definen la "factura" de la re-presentación fotográfica; así como la factibilidad de su manipulación, su uso en diversos contextos con fines también definidos, son las que plantean la discusión sobre: 1) las identidades de la imagen fotográfica $y, 2)$ - las identidades sociales que en ella se procesan.

Respecto al primer punto, pensar las re-presentaciones fotográficas del Gaucho Gil como "documentos visuales" de la religiosidad popular correntina y/o argentina, en tanto evidencia de una realidad o la "prueba" del "haber estado allí" barthesiano, nos lleva a retomar la problematización de la "identidad de la fotografia" ya emprendida por diversos autores durante buena parte del siglo XX a la actualidad.

La mayoría de los intelectuales de referencia afirman que la consideración de la foto pendula entre el documento objetivo (ya arduamente puesto en cuestión) y el artefacto cultural, social e históricamente construido. $\mathrm{Y}$ es esta doble dimensión que opera en los significados atribuidos a la re-presentación fotográfica y que la convierten en una suerte de discurso paradójico.

En este sentido, Allan Sekula insiste que la fotografía "es una entidad inherentemente social, móvil y contingente", siempre atrapada en una paradoja: el mito del cientificismo (objetividad) y el mito del esteticismo (subjetividad); entre la fe en su "verdad" o en su "magia", referidos a un realismo instrumental y realismo mágico, respectivamente (Sekula en Evans y Hall, 1990). Sin embargo, también advierte que cualquiera de los dos anclajes dependen de los usos y papeles atribuidos a la imagen dentro de un sistema de ordenación, clasificación social; sistema que en tanto social, es construido.

Desde esta línea de lectura, las fotografías dejan de concebirse como instrumentos neutros de registro de una realidad para concebirse como un emplazamiento dentro de una cadena semiótica discursiva atravesada por regímenes de regulación del ver y mostrar que, a su vez, condicionan lo que la foto hace visible por la operación de alguien que construye una mirada. Así, el análisis se centra, más allá de la materialidad y lo que exhibe a simple vista la imagen en los modos de construcción de la mirada. 
Geoffrey Batchen agrega una pregunta: “¿debe identificarse la fotografía con (su propia) naturaleza o con la cultura que la idea?” (Batchen, 2004: 24). Lejos de la corriente formalista, el autor también resalta la dimensión "móvil" de la imagen y condicionada por un contexto y el lugar de construcción de la mirada. Más precisamente afirma:

\begin{abstract}
"Al igual que la mirada es variable y sujeta a los diferentes contextos cronológicos, culturales y geográficos, la imagen, a su vez sujeta a la mirada, se convierte también en una inmensa posibilidad de seres, variables, móviles y carentes de una definición concreta (Bachten, 2004: 19).
\end{abstract}

Por su parte, el historiador John Tagg también recalca en que la fotografía "carece de una identidad estable" y que aquellas identidades que se le adosan surgen de su revoloteo por un campo complejo de espacios institucionales vinculados a prácticas y a formaciones históricas y discursivas específicas. Por ello, el autor insiste en que "lo que debemos estudiar es ese campo, no la fotografía como tal" (Tagg, 2005: 89). Desde esta afirmación, tanto la forma de concepción como documento, huella o arte es válida, en tanto y en cuanto las valoraciones en un contexto dado así lo definan. De hecho, una misma fotografía puede asumir cualquiera de estas identidades y esa definición estará condicionada por el contexto de producción/circulación/ recepción.

En el caso que nos ocupa, es claro cómo el contexto define y re-define las posiciones respecto a la imagen fotográfica y por lo tanto sus identidades se movilizan. Así podemos ver cómo varias fotografías de Guillermo Rusconi o Juan Pablo Faccioli cobraron en primer lugar valor de registro "objetivo" de un acontecimiento para indicar que "ha sucedido" y mostrar un detalle visual del mismo en las páginas de los diarios; y de qué modo algunas de las mismas imágenes re-introducidas a través de una muestra fotográfica en espacios de exposición de arte cobraron nuevo valor, resaltándose la interpretación subjetiva que los autores realizaron de lo acontecido; o bien podemos apreciar cómo el famoso retrato del Gaucho Gil de 2008 de Marcos López es expuesto primero en una galería de arte para luego en su circulación llegar a ser apropiada por diversos actores que la valoraron como una "imagen fetiche" y la inscribieron en objetos recordatorios o en el cuerpo a través de tatuajes ${ }^{46}$.

La consideración de la imagen en vinculación con un proceso semiológico discursivo y comunicacional más complejo nos permite realizar algunas reflexiones en torno a la denominación de las fotografías del Gaucho Gil como "fotos de la religiosidad [popular] correntina y/o argentina". Esta identificación del asunto o tema, se construyó desde el sentido

\footnotetext{
${ }^{46}$ Un análisis más desarrollado de los usos y las apropiaciones de las imágenes fotográficas del Gaucho Gil puede leerse en el Capítulo 5
} 
común en relación al reconocimiento de lo que las imágenes exhiben como ritos "no oficiales" -y de allí la atribución del carácter popular- y la localización geográfica como la marca de pertenencia del origen del "santo" - Corrientes como primer espacio de anclaje geográfico y cultural de la devoción- y luego como huella de su expansión a diversos puntos del país -de allí su identificación con la Argentina-. Sin embargo, todas estas marcas de pertenencia desde el análisis de la construcción discursiva -que justamente apunta a desmontar las lógicas constructivas del sentido común- no pueden ser consideradas determinadas, estabilizadas. Se trata de pertenencias provisionales que devienen de los diversos anclajes que la palabra realiza de la imagen con el fin de controlar la proliferación de sus sentidos hacia diversas direcciones (Barthes, 1989).

Por otro lado, consideramos que dichas identidades nominales, o formas de denominación o etiqueta que los sujetos adosan a las fotografías para puntualizar en algún aspecto de lo que las imágenes dan a ver y el modo que lo hacen, catalizan formas de jerarquización y percepción que los grupos sociales poseen de sí en vinculación con los otros. De allí deviene pensar el papel de las re-presentaciones visuales del Gaucho Gil en la construcción y de-construcción identidades sociales sin desatender los diversos procesos de transformación socio-cultural en los que se enmarcan los debates sobre las identidades.

En este contexto, vale preguntarse ¿qué rol ocupan en la configuración de este "mundo" agigantado del Gaucho Gil y la re-definición de identidades sociales a este vinculado el incremento de las migraciones internas de las últimas décadas en la Argentina?; es decir, referimos a la movilización de masas de correntinos en todo el país y radicación principalmente el Gran Buenos Aries y el Sur argentino entre mediados del siglo XX a la actualidad y principalmente a mediados de la década de 1990 a $2001^{47}$ que se constituyeron en espacios donde a partir del neoliberalismo de los noventa se manifiesta, a su vez, el crecimiento del culto al gaucho milagroso y con él la proliferación de imágenes; y ¿qué el papel jugó y juega en el proceso de visibilización de la diversificación religiosa argentina la proliferación imágenes del Gaucho Gil junto a la massmediación expandida de la cultura experimentada entre los años ochenta y noventa? Y en este marco de complejidades: ¿la insistencia en la localización geográfica de la práctica cultural sigue siendo la única pregunta vital para la definición del "mundo" del Gaucho Gil y las dimensiones identitarias a este asociado? o ¿debiéramos preguntarnos además por esa localización y su devenir, por los

${ }^{47}$ El licenciado Carlos Quiñonez señala que Corrientes es una provincia expulsora de población como todas las del norte argentino y que la mayoría de los emigrantes se radicaron en el Conurbano para trabajar en las industrias que surgieron con el primer peronismo. Actualmente, según cálculos gruesos se estima que habría entre 700 mil y un millón de correntinos viviendo fuera de la provincia (Quiñonez en Saidon, 2011). 
procesos de des-localización y re-localización que los fenómenos culturales atraviesan, por su movilidad mediada por la re-producción de imágenes? ${ }^{48}$.

Stuart Hall en el análisis de las identidades sociales, a las que considera como relacionales, posicionales y contingentes, recalca que:

\begin{abstract}
"Es preciso que situemos los debates sobre la identidad dentro de todos esos desarrollos y prácticas históricamente específicos que perturbaron el carácter relativamente "estable" de muchas poblaciones y culturas, sobre todo en relación con los procesos de globalización, que en mi opinión son coextensos con la modernidad (Hall, 1996) y los procesos de migración forzada y "libre" convertidos en un fenómeno global del llamado mundo "poscolonial". Aunque parecen invocar un origen en un pasado histórico con el cual continúan en correspondencia, en realidad las identidades tienen que ver con las cuestiones referidas al uso de los recursos de la historia, la lengua y la cultura en el proceso de devenir y no de ser; no "quiénes somos" o "de dónde venimos" sino en qué podríamos convertirnos, cómo nos han representado y cómo atañe ello al modo como podríamos representarnos" (Hall, 2003: 17-18).
\end{abstract}

Por su parte, Arjun Appadurai (2001) habla de la constante tensión entre lo local y lo global y su influencia en la interacción permanente entre tendencia homogenenizadora y la heterogeneización; puja que exige del análisis de la cultura contemporánea ir más allá de la localización geográfica de origen de una práctica para atender los modos en que ellas se desplazan y se redefinen a través de re-presentaciones que entran en relación con la globalidad de la economía y de la cultura.

En el marco de estas tensiones local-global y la configuración de "identidades en diáspora” (Hall, 2010), Appadurai también señala la importancia que cobran las imágenes en los nuevos modelos de imaginación de la vida social:

"El trabajo de la imaginación no es ni puramente emancipador ni completamente disciplinado, sino que es un espacio de enfrentamiento en el que individuos y grupos sociales buscan anexionar lo global a sus propias prácticas de lo moderno (...) La imagen, lo imaginado y lo imaginario son términos que nos conducen hacia algo importante y nuevo en los procesos culturales globales: la imaginación como práctica social" (Appadurai en Mirzoeff, 2003: 5556).

En este sentido, desde su análisis de la cultura global visual Mirzoeff (2003) resalta, citando a Rogoff (1998), el modo en que la gente se imagina desde la visualidad; crea "inesperadas narraciones visuales" de la vida cotidiana "partiendo del pedacito de una imagen que conectan" con publicidades, films, portadas de diarios, internet, etc. Por ello, insiste en que la cultura visual "que antes era considerada para salir de campos tan serios como los textos y la historia, ahora se ha convertido en el emplazamiento de un cambio cultural e histórico" (Mirzoeff, 2003: 58).

${ }^{48}$ Algunas de estas preguntas son retomadas en el Capítulo 3. 
En esta trama de construcción de la imaginación visual de lo social se movilizan las re-presentaciones del Gaucho Gil actuales, que también partieron de un pedacito de imagen (la imagen más conocida de la estampita del "santo") para abonar la construcción del mundo visual del Gaucho Gil expandido. Ese mundo visual adopta hoy el carácter de una "red fractal" (Powers en Mirzoeff, 2013: 50)- que no solo refiere a una tradición cultural, visual y religiosa sino que está impregnada por elementos de modelos culturales disímiles.

En esta compleja red visual, donde incluso se da una interrelación de límites también difusos entre lo real y lo virtual, es decir, abonando lo que Mirzoeff denomina red de “intervisualización global”, las re-presentaciones fotográficas del Gaucho Gil en su pasaje por diversos campos -el periodismo, la documentación, el arte- tampoco resisten una identificación estática con nociones como religiosidad o religiosidad popular. Incluso volviendo a la conjetura de Tagg, resulta polémico intentar anclar los múltiples sentidos que vehiculizan y disparan las fotos restringidas sólo a dichas nociones, y más problemático aún resulta cuando las mismas nociones en el campo de los estudios de las religiones están siendo puestas en discusión de modo permanente, justamente por la creciente heterogeneización que atraviesan las religiosidades contemporáneas, entre ellas se ubican las vinculadas a la figura del Gaucho Gil.

La propia experimentación subjetiva de la fotografía que referencia e interpreta el mundo del Gaucho Gil desafía permanentemente los límites de su clasificación dentro del dominio de "lo religioso". En otras palabras, como todas las imágenes, también estas fotografías albergan la capacidad de escapar a la fijación de los sentidos impuestos, siendo ello lo que habilita su utilización y re-significación dentro y también fuera de los ámbitos de la religiosidad.

\section{Pensar imágenes en el "ámbito religioso" y más allá: discusiones nominales}

Del mismo modo en que pensar la fotografía como documento, huella de memoria o arte plantea múltiples discusiones y marca muchos caminos de abordaje posible, presentándose el contexto de producción/circulación y la palabra que la nombra como puntos de sujeción o sutura no definitiva, la relación de la re-presentación fotográfica del Gaucho Gil con el ámbito de "lo religioso" también presenta una provisionalidad que está atada a posiciones de valoración específicas. Desde la observación de las prácticas en torno al "santo" popular de referencia, algunos indican que dichas manifestaciones representan formas de 
religiosidad popular, otros a formas de religión, de religiosidades, o de prácticas de sacralización; e incluso formas de desviadas de la religiosidad o representaciones de prácticas "paganas", entre otros.

Evidentemente, hablar de religiosidad popular, religiosidades, entre otras nominaciones, implica ingresar a los extensos y espinados debates sobre "terminologías", “denominaciones" que responden a preocupaciones epistemológicas más vastas dentro de los estudios de la "religión" de las ciencias sociales que aún no encuentran un consenso mayoritario. Dichas preocupaciones, en principio podríamos decir que no hacen al foco problemático de nuestra tesis: la productividad de las fotografías en el seno de las prácticas sociales y discursivas, particularmente, las "religiosas"; sin embargo, en una mirada detenida advertimos que repercuten de lleno en el planteo desde la consideración de las identidades que textualizan las imágenes en el seno de las "prácticas religiosas" o "de sacralización", y por ende, hacen a su dimensión constructiva, a su vinculación con el contexto y las relaciones intersubjetivas que les otorgan sentido. Por ello, aquí realizamos algunas aproximaciones a las nociones de religión, religiosidad, religiosidad popular, prácticas religiosas $\mathrm{o}$ de sacralización, para luego establecer relaciones con las re-presentaciones fotográficas del Gaucho Gil; esto sin ánimos ni recursos de/para agotar la discusión que tiene mayores y fructíferos desarrollos entre los grupos que centran sus estudios en los procesos, prácticas, historia(s) y experiencias de la(s) religiosidad(es) ${ }^{49}$.

Etimológicamente "religión" viene del latín "religare", lo cual significa "ligar o unir fuertemente". En el sentido del término y desde un punto de vista muy general, entonces la religión puede ser concebida como lugar de memoria y de identidad vinculante o, quizás mejor, como expone Rita Segato (2007) "una descripción codificada del mundo desde una perspectiva particular y situada, marcada por la cultura y la experiencia social". Por su parte, Fogelman arriesga una posible concepción general $-\mathrm{y}$ simplificada según su propia advertencia-:

\footnotetext{
“...la religión es una construcción histórica y social, conformada por un conjunto articulado de ideas, discursos y prácticas, manifestada en diversas expresiones y que implica las relaciones imbricadas pero jerárquicas, de distintos actores sociales en escenarios comunes, tanto como individuales. Se trata de un conjunto mutable -históricamente construido y cambiante- a pesar de los diversos ritmos que estos cambios implican" (Fogelman, 2010: 13).
}

\footnotetext{
${ }^{49}$ Referimos a los avances alcanzados por aquellos estudiosos nucleados en o que dialogan con la Asociación de Cientistas Sociales de la Religión en el Mercosur (ACRM); el Grupo de Estudios sobre Religiosidad y Evangelización (GERE) del Instituto Ravigniani y la UBA; Diversa: Red de Estudios de la Diversidad Religiosa en la Argentina; el Grupo Interdisciplinario de Estudios sobre el Pluralismo Religioso en Argentina; entre otros numerosos núcleos, institutos, revistas y jornadas exclusivamente dedicadas a este campo de estudios.
} 
Fogelman, desde una lectura de los estudios culturales, además plantea su desacuerdo en ubicar a la "religión" en una condición de superioridad o vinculada al culto oficial -de allí que algunos la escriban con R mayúscula- en relación al término de "religiosidad", por lo que utiliza estas denominaciones como sinónimos. Esta consideración es valiosa y en esta línea también esta tesis plantea la religiosidad no en términos de relación subordinada a la noción de "religión".

Por otra parte, Fogelman abre dudas y reservas en torno a la noción "religiosidad popular" en el sentido que la mayoría de la bibliografía a ella referida - no toda- ha direccionado su uso en una orientación "a veces peyorativa, otras demagógica respecto de ciertas representaciones y prácticas de la religión que se le atribuyen a los grupos sociales subalternos" (Fogelman, 2013: 2005). Estas posiciones, plantean escollos y limitaciones que otros autores han intentado superar, unos manteniendo el término de "religiosidad popular" o, refiriendo a "religiosidad(es) de los sectores popular(es)", otros proponiendo hablar de "religiosidades" en términos más amplios, o bien de "prácticas de sacralización".

Esta breve introducción a los debates sobre la noción de "religión" afirma lo que Talal Asad insiste: no es posible dar una definición universal de religión "no solo porque sus elementos y relaciones constitutivas son históricamente específicos, sino porque su definición es en sí misma el producto de un proceso discursivo complejo" (Asad, 1993 en Martín, 2007). Una dificultad que también se da en la definición de "religiosidad popular" y que no podemos pasar por alto al referirnos a manifestaciones ligadas a la figura del Gaucho Gil, a las que varios autores entienden como ejemplares de la religiosidad popular argentina (Frigerio,1995; Semán, 2006, entre otros).

Forni define religiosidad popular como:

“..el tipo de culto que es prácticamente paralelo e independiente de la Iglesia y el control
clerical. El pueblo no solo espera resultados mágicos, sino que concibe a la religión como una
directa relación con la divinidad usando como mediadores imágenes, la virgen, los santos, los
muertos en vez de (o paralelamente con) una mediación de la Iglesia a través de la disciplina
sacramental" (Forni, 1986: 14).

Como punto de partida podría tomarse esta concepción de Forni, como también sugiere Frigerio (1995) al abordar el fenómeno de la secularización y los nuevos movimientos religiosos en la Argentina; no sin antes indicar que las conceptualizaciones en general nos conducen al campo de un extenso debate donde historiadores, sociólogos, antropólogos, entre otros, han propuesto nociones diferenciales que se enmarcan en trayectorias de investigación particulares. 
Eloisa Martin en su contribución a los estudios sobre el concepto de "religiosidad popular" realiza un relevamiento exhaustivo de la literatura que aborda la cuestión en la Argentina en los últimos 25 años, dividiendo a los autores en cuatro grupos: 1) aquellos que identifican la religiosidad popular con "la religión del pueblo, presentándola en un eje vertical, donde aparece en el polo 'dominado', mientras la Iglesia, el Estado, o la burguesía capitalista se presentan como "dominantes"”; 2) aquellos que "colocan sus focos en las 'funciones' que la religiosidad popular cumple en los sectores más pobres de la población: como un modo de enfrentarse a situaciones de carencia educativa, material y espiritual"; 3) los que proponen "la existencia de 'otra lógica' para analizar los fenómenos religiosos en la Argentina: no como un modo de resistencia a la dominación ni como una forma de lidiar con las carencias, sino desde su positividad creadora"; 4) se trata de la propia propuesta de Martin para pensar "lo sagrado" más allá de "lo religioso" por su lectura crítica del concepto "religión" y verlo en términos de "textura diferencial del mundo-habitado" y de "prácticas de sacralización” más que prácticas religiosas (Martin, 2007: 64-65).

Teniendo en cuenta este recorrido, esta tesis retoma en los capítulos que siguen principalmente los aportes de la tercera y cuarta línea de lectura señalada por Martin, tomando en consideración las características de la festividad y las prácticas diversas asociadas a la figura del Gaucho Gil, desde las que pensamos la "vida" de las fotografías ${ }^{50}$.

Más allá de los límites epistemológicos que algunos estudios puedan presentar, nos interesan desde la tercera línea lectura, las investigaciones empíricas y el desarrollo de premisas de Cristian Parker, Aldo Ameigeiras, Alejandro Frigerio, María Julia Carozzi, Eloisa Martin, Pablo Semán, entre otros ${ }^{51}$, en tanto permiten superar la restricción del análisis de este campo de la religiosidad a la relación dicotómica institucional/popular - popular/ dominante; y posibilitan dejar de pensar las prácticas de los sectores populares como subordinadas a las imposiciones de los dominantes o como formas "desviadas" de la cultura hegemónica, como “carencia”, como "desposesión"; posición que incluso va de la mano de aquellas lecturas que han enjuiciado el mundo popular como parte de la no-cultura (Barrios, 2013 y 2014). Asimismo, el trabajo de estos intelectuales posibilita reconocer las instancias de autonomía y la capacidad creadora de los sectores populares desde sus prácticas, sin descuidar las relaciones de poder en las que éstas se insertan.

\footnotetext{
${ }^{50}$ Acerca de las características centrales de la festividad y la figura del Gacho Gil ver la Introducción y mayores desarrollos de su historicidad en el Capítulo 3.

${ }^{51}$ Estas contribuciones son retomadas en el apartado 3 del presente capítulo y en el Capítulo 3.
} 
Por otro lado, la cuarta línea abierta por Martin permite observar la articulación de estas prácticas del ámbito "religioso" con aquellos campos que exceden ese dominio y que lo afectan y lo re-significan ${ }^{52}$. A su vez, este marco de referencias posibilita pensar de otro modo las re-presentaciones del Gaucho Gil en el contexto de campo religioso y su relación con otros campos. Es decir, permite ver el modo en que los sectores sociales que entran en vinculación en estos ámbitos utilizan lo visual, crean imágenes para tensionar las posiciones que configuran ese "campo religioso" y cómo las imágenes son apropiadas por diversos grupos y adquieren permanentemente nueva vida, escapando del control de su creador primogénito, transitando y conectándose con otros campos.

Siguiendo a Fogelman, la tesis adopta una estrategia de análisis que deja de ver a las imágenes como "un ornato banal de los textos" vinculado al ámbito religioso e "incluso en el caso de aquellas que son $-\mathrm{y}$ de las que parecen ser- adorno de los textos, también es necesario reflexionar sobre sus sentidos, funciones y relaciones de conjunto" y que en tanto representaciones materiales hay que considerarlas "parte integrante de la realidad" (Fogelman, 2010:11).

\section{Estudios sobre religiosidad, comunicación y cultura visual: debates} compartidos

La indagación de las prácticas y representaciones de los sectores populares desde su positividad creadora y más allá de noción de carencia y/o la relación dicotómica y oposicional institucional-oficial/popular - popular/ dominante - dominante/dominado, como propone una de las líneas de los estudios de la "religiosidad popular" (Martín, 2007), atraviesa debates compartidos también por los estudios de la comunicación latinoamericana, los estudios culturales y la cultura visual. Las preguntas centrales de estas reflexiones giran en torno a la noción de cultura. ¿Qué entendemos por cultura?; ¿hay sectores activos y otros pasivos en la producción de la cultura?; ¿se puede seguir hablando de la división de la cultura en dos, siguiendo la línea de estudios sobre la distinción de clase de Pierre Bourdieu ${ }^{53}$; ¿es tiempo de hablar de culturas y de la interacción entre éstas?.

\footnotetext{
52 Sobre estas aperturas en los caminos de investigación del campo religioso se vuelve en los apartados que siguen.

53 Referimos al texto "Gustos de clase y estilos de vida", en La distinción: criterios y bases sociales del gusto (1979). Allí Bourdieu realiza el abordaje de los gustos y prácticas culturales como expresiones simbólicas de la posición de clase que asumen los actores en la estructura social. Se trata de una posición que se concibe establecida por la posesión de determinado capital socio-cultural, económico y simbólico y que instituye a las personas como agentes de clase dominante, media o popular. Asimismo, dicha posesión y posición se plantean
} 
Sin lugar a dudas, la noción de cultura es una de las más discutidas en el ámbito de las ciencias sociales y vale revisitar algunos recorridos reflexivos que en parte delinean el enfoque transdisciplinar de nuestro análisis a partir de los cuestionamientos citados. En este sentido, cabe señalar que la concepción de los sectores populares como "sujetos" adquieren un rol activo y no meramente pasivo en la producción cultural, incluyendo los ámbitos de la religión y de la cultura visual, remiten a extensos debates también desarrollados por Raymond Williams, E.P. Thompson, Stuart Hall, Jesús Martin-Barbero, Néstor García Canclini, Aníbal Ford, Eduardo Romano, Jorge Rivera, entre otros, desde el campo de los estudios culturales y la comunicación.

Es decir, por un lado, hablamos de una posición que intenta dejar de ver la religiosidad [de los sectores] popular[es] desde la mera negatividad para comprenderla desde la positividad creadora y atendiendo a las relaciones conflictividad que ella supone; y por el otro, la posición que intenta dejar de enjuiciar al espectador de las imágenes en la cultura de masas como mero consumidor pasivo/ víctima de las clases dominantes y el mercado para comprender también su rol de productor/consumidor, siempre condicionado por relaciones de poder y dominación. En otras palabras, estas posturas en los campos de los estudios de la religiosidad y de la cultura visual, devienen de pensar una noción de "lo religioso" y "lo visual" desde la cultura. Reflexiones que se articulan estrechamente con las preocupaciones de los estudios de la comunicación desde la cultura (Comunicación/Cultura) y en plena conexión con las discusiones sobre "lo popular" que los estudiosos de la comunicación latinoamericana adelantaron entre los años setenta y ochenta del siglo XX. A continuación vemos algunas reflexiones ${ }^{55}$ y sus intersecciones.

En un contexto alejado del nuestro, la sociedad inglesa de los setenta, el historiador inglés Edward Palmer Thompson presentó un nodo reflexivo clave para pensar un cambio de paradigma en la consideración de "lo popular" que marcaría las reflexiones de los estudios

como pre-figuradoras de los "estilos de vida para sí" o "estilos de vida en sí". Es decir, estilos de vida propios basados en la libertad de disponibilidad de bienes y estilos de vida de sumisión cultural, ajustados a la necesidad y al desposeimiento. La postura fue cuestionada por la tercera línea de los estudios de la religiosidad citada por Martin (2007), especialmente se lee en los textos de Pablo Semán. Asimismo, varios intelectuales de los estudios culturales y la comunicación hacen hincapié en la superación de la posición dominocéntrica de la cultura popular que expresa el texto de Bourdieu, como la de otros autores, y por su parte, explícitamente desde los estudios visuales, Mirzoeff (2003) cuestiona que se siga sosteniendo en la compleja actualidad, una división de la cultura propuesta por el autor en los sesenta y basada en una encuesta muy reducida y teñida de prejuicios.

${ }^{54}$ Las posiciones subjetivas discursivas no son entendidas aquí como categorías a priori que los individuos ocupan sin conflicto por orden de la norma sino implica también una autoconstitución, reconocimiento actuación del sujeto en cuanto tal en relación variable (de atención, resistencia, rechazo, negociación) respecto a la regulación; “articulación” sin lo cual no habría sujeción/subjetivación (Hall, 2003).

55 Advertencia: el recorrido presenta un mapa incompleto de autores y reflexiones claves que atraviesan los campos de interés. Éstos y otras contribuciones se irán retomando en los análisis posteriores. 
culturales ingleses y latinoamericanos. En sus indagaciones sobre la clase obrera inglesa del siglo XVIII al siglo XIX, el autor pone en discusión la visión "consensual" de la cultura entendida como "sistema de significados, actitudes y valores compartidos" y cuestiona que esta visión solo ha servido para "distraer la atención de las contradicciones sociales y culturales, de las fracturas y las oposiciones dentro del conjunto" (Thompson, 1995: 19).

En esta línea, Thompson - con una marcada influencia gramsciana, algo que también caracteriza a la crítica latinoamericana de la comunicación- recupera la categoría de clase en el análisis de la conformación social y cultural, la idea de conflictividad social y de prácticas atravesadas por relaciones de poder; así como la consideración de la dimensión política concreta de las acciones de los sectores populares, no meramente reductibles a la idea de respuesta a "estímulos económicos". A partir de un artículo publicado en 1971 en la revista inglesa Past and Present y reproducido en Costumbres en común (1995), reflexiona sobre los denominados "motines de subsistencia" propiciados por la clase de trabajadores ingleses del siglo XVIII que incluyeron saqueos y principalmente bloqueos a comerciantes y molineros como modo de protesta contra la exportación de los alimentos.

El historiador explica en ese texto en términos de "economía moral de la multitud" cómo los denominados "motines de la subsistencia" no surgían simplemente como reacción por el hambre (carencia) y el fin de evitar el desabastecimiento de alimentos, como pretendían hacer notar las concepciones economicistas. Por el contrario, Thompson los comprende como reclamo activo y reacción por parte de los sectores populares ante las autoridades contra el atropello a los valores morales y culturales y a las normas tradicionales de equidad distributiva vigentes que traía consigo aparejado el proceso de industrialización y la adopción de una economía de libre comercio. En este contexto, el autor concibe a las protestas como formas muy complejas de "acción popular directa, disciplinada y con claros objetivos", no reductibles a la concepción desideologizada y descontextualizada del motín.

En esta línea, Aníbal Ford, referente del pensamiento crítico latinoamericano de la comunicación en su texto escrito en los setenta y vuelto a publicar en los ochenta bajo el título "Cultura dominante y cultura popular", también convocó a pensar la cultura popular como "un concepto que introduce el conflicto en el territorio de la cultura". Allí rechaza la visión elitista y dominante que entendía la cultura como "la universal, la única cultura, la civilización" que debe ser distribuida entre los sectores populares "carentes" de la misma. En contra de ese concepto de "cultura burgués" Ford llamó a un pensamiento crítico "por la afirmación de la cultura nacional y popular"; un pensamiento que fuera capaz de reivindicar la capacidad creadora y productora de los sectores populares, echando por tierra la 
idea de que son masas fácilmente manipulables, dependientes y reproductoras del orden existente (Ford, 1985: 20-21).

Ford abrió en la Argentina una discusión sobre la politicidad de las prácticas de los sectores populares. También, Eduardo Romano en "Apuntes sobre cultura popular y peronismo", escrito de la década del setenta analiza cómo los sectores subalternos han mantenido un rol activo propulsando "una variante diferenciada de cultura", ante la cultura de elite que se imponía como "la cultura", con medios y modos de difusión alternativa que adquirieron especial visibilidad pública y mediática bajo el peronismo (Romano, 1973). En esta línea, Ford, Romano y Jorge Rivera inauguran el análisis sobre objetos hasta el momento no indagados, como los letristas de tango, el folletín, el radioteatro, entre otros. Estas reflexiones y aquellas publicadas en las revistas Comunicación y Cultura y Crisis con los aportes de importantes intelectuales se sentaron precedentes para pensar sobre el patrimonio cultural nacional, la memoria histórica popular, los cambios en la industria cultural, las relaciones entre cultura popular y masiva (Alabarces, 2008; Grimson y Varela, 2002).

Por otra parte, los planteos de Jesús Martin-Barbero, referente de los estudios latinoamericanos de la comunicación, desde la década del ochenta a esta parte ayudaron a comprender que si bien desde sus inicios la cultura de masas respondió a los intereses de homogeneización religiosa y centralización política, también ella abrió a las clases populares "el acceso a la cultura hegemónica" y les dio "la posibilidad de hacer comunicable su memoria y su experiencia" (Martin-Barbero, 1998: 133). Asimismo, con su requisitoria al campo de la comunicación de volver la mirada de los medios a las mediaciones, MartinBarbero insistió con el estudio de las articulaciones entre la cultura popular y masiva para señalar aquellas narrativas masivas que circulan por dispositivos masivos "y de cuyos rasgos temáticos, retóricos $\mathrm{y}$ enunciativos se desprende un vínculo con matrices culturales históricas de los sectores populares" (Rodríguez, 2010: 11).

En el seno de estos debates, fueron principalmente los trabajos de Martin-Barbero y Néstor García Canclini, producidos durante las transiciones democráticas latinoamericanas, los que instalaron la cuestión de la cultura popular como preocupación central en la agenda de las investigaciones en comunicación de la región aunque con enfoques diferentes ${ }^{56}$.

Por otra parte, en el ámbito de los estudios de la "religiosidad" de los sectores popular(es), es clara la continuidad que la tercera línea de lectura -señalada por Martin

${ }^{56}$ Esto es, la línea barberiana tendiente a indagar lo popular en su especificidad y desde la experiencia de los sujetos consumidores y productores no fuera de lo masivo y en diálogo con sus matrices culturales-históricas; y la cancliniana a explorar el consumo cultural popular regido por el habitus (Rodríguez, 2010). 
(2007) - le da a las reflexiones abiertas por Thompson, entre otros, y también las críticas efectuadas Grignon \& Passeron, quienes insistieron en la necesidad de superar la visión dominocéntrica en los análisis de las prácticas culturales pero sin caer en el relativismo populista (Grignon \& Passeron, 1989). Específicamente, en referencia a las orientaciones sugeridas por estos autores, Pablo Semán recalca:

\begin{abstract}
"Para ellos, se trata tanto de que los intelectuales que estudian la cultura popular no olviden los efectos que produce la dominación en la cultura, como de que se observe que en algunos momentos, que no son todos, los dominados actúan más que de forma rebelde en terrenos de "insumisión cultural", en los que sucede un transitorio "olvido de la dominación", pleno de consecuencias sociales y analíticas (Grignon \& Passeron, 1989: 68). En última instancia, esto se asocia a la necesidad de superar la obsesiva presencia del eje resistencia-dominación en el análisis" (1989: 75)” (Semán, 2009: 200).
\end{abstract}

Las nociones de "insumisión cultural” y de "olvido de la dominación” que introduce Semán resultan centrales para describir/analizar los complejos procesos materiales y culturales del "mundo del Gaucho Gil”. Un mundo que además de presentar la reproducción y apropiación de elementos del culto oficial y vehiculizar una idea de "justicia social" asociada a la imagen del Gil como un "héroe liberador" de los sectores oprimidos (Lojo, 2007; Chumbita, 1995); supone la convergencia de cosmovisiones y prácticas sociales ligadas a matrices culturales polisémicas que exigen ir más allá de la lectura vinculada a la idea de sumisión y dominación.

Hablamos de ese "mundo" como un espacio intersticial donde se vinculan activamente formas de construcción de identidades individuales y colectivas; donde se revitalizan prácticas funerarias en torno a la muerte y la (re)memoración de los difuntos, a su vez vinculadas a tradiciones disímiles y matrices culturales de larga data. Asimismo ese "mundo" configura una festividad central los ocho de enero a partir de la cual se re-construye un sistema de reciprocidad, de intercambio circular entre las personas y la divinidad; sistema que basa en promesas, exvotos, sacrificios y la acción de compartir intrincada en lazos de religación familiar y comunitaria. En relación a esto último, la festividad del Gaucho Gil plantea la actualización creencias y prácticas que construyen una forma de relación cercana entre los devotos y el "santo", a quien fieles y seguidores consideran "un amigo", "compañero", una divinidad "más terrenal" por su condición de haber sido un hombre con aciertos y desaciertos ${ }^{57}$; y además se lo plantea como propiciador de milagros que adquieren

\footnotetext{
${ }^{57}$ Los imaginarios construyen al Gauchito Gil como un personaje por naturaleza antagónico. Como héroe, que robaba a los ricos para dar a los pobres, estableciendo un nuevo sistema de reparto de la riqueza, entre otras cualidades; y por el otro como antihéroe por sus prácticas delictivas. En este sentido, como señala Martin, pareciera ser un "ser extraordinario" que precede toda moral participando de una "textura diferente del mundo
} 
un carácter cotidiano más que de fenómeno extraordinario. También el acontecimiento en enero imbrica lo "mítico-mágico y religioso" de la conmemoración con escenas de espectáculo, mediatización y entretenimiento; música diversificada, comida, teatralización de los cuerpos y las pasiones y comercialización.

Estos elementos, entre otros, exigen la apertura a la discusión de "lo religioso" ligado al Gaucho Gil desde una concepción “cosmológica, holística y relacional”, que en términos de Semán, confronta con la visión modernocentrista que separa lo natural y lo sobrenatural, lo inmanente y lo trascendente, lo físico de lo moral-espiritual; y que promueve una vinculación individualista del hombre con lo sagrado. La visión ensayada por Semán resalta cómo las prácticas de religiosidad contemporánea de los sectores populares "están más acá" de las distinciones y posiciones modernas.

En este sentido, las prácticas vinculadas a Antonio Gil pueden concebirse "cosmológicas, holísticas y relacionales" en tanto que lo sagrado se plantea como "un nivel más de la realidad" y no separado de ella; también porque suponen "un continuum físicomoral que integra a los sujetos como padres, hijos, ahijados y rivales"; es decir, más allá de la posición individualista moderna "también permite la circulación de lo sagrado por las vías de los lazos sociales" (Semán, 2001: 54-66).

De allí la importancia de asumir un enfoque que "más allá de los condicionamientos derivados de las situaciones de subalternidad y privación, asuma su positividad y el sentido fuerte de la diferencia que esa cultura presenta" (Semán, 2001: 48); y tener en cuenta que "las culturas populares no están detenidas en un alerta perpetuo ante la legitimidad cultural, pero tampoco hay que suponerlas movilizadas día y noche y en alerta contestataria. También descansan” (Semán, 2009: 200).

Asimismo, desde a lectura de Semán y en relación a la complejidad de las prácticas y re-presentaciones que nos ocupan, es relevante comprender además de la "diferencia radical" de la religiosidad popular, el modo en que esa "visión cosmológica" se "articula de forma diversa y plural, pero de ninguna manera infinita, o incomprensible, en diálogo, con lo que muy malamente podemos llamar, 'las fuerzas de la modernidad”' (Semán, 2010: 71).

En este sentido, en el Capítulo 3 se enfatiza el análisis de los modos en que las representaciones vinculadas al Gaucho Gil -además de estar relacionadas con grandes relatos identitarios (de la nacionalidad, la correntinidad, etc) -, se encuentran atravesadas por las mediaciones de la industria cultural -la comunicación audiovisual, producciones televisivas,

que es previa a la concepción cristiana que considera lo sagrado como lo infinitamente bueno, en contraposición a lo profano, el lugar del mal" (Martin, 2004). 
el turismo, la mercantilización de las prácticas culturales y la producción masiva de bienes materiales (objetos mnemónicos, talismanes, protectores, etc.)-; y cómo particularmente las imágenes (fijas y móviles) modernas y de la cultura masiva cobran un rol preponderante en estas mediaciones, revitalizando y re-significando desde lo visual maneras de creer que surgieron estrechamente ligadas a memorias orales y prácticas mágicas de la cultura popular y de tradición pre-moderna ${ }^{58}$.

Hablamos de maneras de creer que se anclan en el hacer ${ }^{59}$ y que, en el caso de interés, más allá de vincularse a un santuario o a una imagen central -con asiento en la ciudad de Mercedes, Corrientes-, se construyen y re-producen en el peregrinar, en los viajes, las rutas, los objetos, los cuerpos y sus desplazamientos. Es decir, en espacios en tránsito que configuran, a su vez, nuevos modos de construcción de los territorios donde las "iconicidades móviles" juegan un rol central, que como señala Segato (2007) es otro proceso que caracteriza a las formas de la religiosidad contemporánea.

La suma de estos flujos y movilidades, con un rol destacado de las imágenes como parte central en la configuración de la vida cotidiana, plantean según el análisis de Appadurai el "nexo entre lo global y lo moderno". Una intersección que impacta de lleno en el "trabajo de la imaginación” contemporánea (Appadurai, 2001). En este contexto, las viejas teorías sobre "sistemas culturales cerrados" 60 se desmoronan y las nuevas reflexiones convocan a comprender las interacciones entre esos "sistemas" a partir de la porosidad y labilidad de sus fronteras. Aquí, como indica Mirzoeff siguiendo las reflexiones de Hall sobre la cultura entendida como "práctica" más que como sistema estanco "los enfoques transculturales" se

\footnotetext{
${ }^{58}$ Mallimaci y Giménez, siguiendo a Pierre Sanchís, resaltan que la modernidad en América del Sur "se afirma en diversos planos, pero no a partir de una linealidad única, sino combinando elementos pre-modernos, modernos y post-modernos que no determinan etapas sucesivas sino que se articulan dando lugar a configuraciones originales". Agregan: "Se trataría, en suma, de 'lógicas co-presentes en combinaciones variadas en las mismas situaciones' (Sanchís, 1997: 105), que generan formas de creencia (y de increencia) tradicionales, asociadas con religiosidades centradas en el individuo y con construcciones institucionales racionalizadas" (Mallimaci y Giménez, 2007).

59 Siguiendo a De Certeau, se entiende el creer en su dimensión performativa; es decir una creencia ligada, actualizada y solo posible en la práctica; por ende también procesual y transformable (De Certeau, 2000). Como insiste Semán, la unidad de análisis del creer es el proceso y no las creencias, los creyentes y las instituciones que son sólo un "momento". "El creer implica creyentes e instituciones y, sobre todo, tradiciones que se invocan en el cruce de múltiples trayectorias subjetivas, múltiples tradiciones y múltiples creencias. El creer es comunicación con todas las incertidumbres que le asisten al comunicar e insanablemente procesual, en un desplazamiento sin fin"(Semán, 2013)

${ }^{60}$ Un claro ejemplo es el estudio etnográfico de Abu Lughod (2006) sobre el consumo de las series de televisión en aldeas de Egipto, las culturas interactúan desde el hogar y a través de la apropiación de las visiones de mundo que vehiculizan las pantallas. En ese marco, se producen "cosmopolitismos discrepantes". Las culturas en relación presentan elementos que "son financiados, producidos, censurados y re-trasmitidos a través de una nación, o incluso más allá de las fronteras nacionales” (Abu- Laghod, 2006: 132).
} 
plantean como "herramienta calve en la diáspora global del mundo moderno" (Mirzoeff, 2003: 49).

\section{Lo visual entre prácticas de sacralización en un campo religioso}

\section{heterogeneizado}

Señalamos que esta tesis sigue en el ámbito de los estudios de la religiosidad popular, la tercera y cuarta línea de lecturas clasificadas por Martin (2007). A la tercera, nos referimos brevemente en el apartado anterior resaltando los planteos sobre la particular visión de lo popular en relación con el carácter trasversal de la religiosidad en la cultura contemporánea. De aquí en adelante referenciamos a la cuarta línea que hace alusión a la propia propuesta de Martin para pensar "lo sagrado" más allá de "lo religioso". La socióloga revisa el concepto "religión" y propone verlo en términos de "textura diferencial del mundo-habitado" y de “prácticas de sacralización” más que como prácticas religiosas (Martin, 2007: 64-65).

Martin se ocupa de ampliar los senderos conceptuales trazados por otros estudiosos de la religiosidad sobre el mundo de "lo sagrado" cuando se encuentra con experiencias "religiosas" que a su entender rebasan el dominio de lo religioso. Entonces, plantea enfocar los estudios en las "prácticas de sacralización” más que hablar de religiosidad o de prácticas religiosas. Esta vía para la autora permite:

“..1) evitar las concepciones dualistas que dividen lo sagrado de lo profano, y definen lo popular en contraposición a lo institucional, lo oficial o lo dominante; 2) eludir el innatismo apriorístico de las definiciones clásicas focalizando en los procesos y no en ontologías; 3) acceder a los 'híbridos', que no son tales: las prácticas nativas combinan 'religión' con política, arte, música, economía de forma que exceden el modelo modernocéntrico de la división de esferas; 4) volver visibles los conflictos, no apenas entre la Iglesia y los laicos, sino en el propio núcleo de las prácticas de sacralización: así, no es necesario descartar los casos que no se adecuan al modelo clásico de la devoción ni imponerles lógicas ajenas; y 5) designar una práctica específica (lo que es diferente a afirmar que 'todo es religión'), pero no abstracta: su contenido es definido por los nativos" (Martin, 2007: 78-79).

Específicamente, la reflexión surge cuando Martin observa los componentes heteróclitos de la devoción/fanatismo por Gilda, la cantante de cumbia argentina devenida en “santa” popular en la década del 90'; es decir, cuando ve la presencia de una articulación de experiencias religiosas con elementos del mundo de la música y la cultura del espectáculo. Intersecciones y matices interesantes a ser considerados en relación al fenómeno del Gaucho Gil.

Una de las tesis que maneja Martin es que muchas personas que se identificaron a sí mismas como fans de Gilda, y no precisamente como devotos, colaboraron a través de 
diversas prácticas en el proceso de consagración de "excepcionalización" de la fallecida cantante (Martin, 2004). Algo similar -aunque no estrechamente comparable- surge con los "simpatizantes" que recoge el Gauchito Gil, entre ellos: artistas, periodistas, fotógrafos, quienes participan activamente a través de diversas formas de simbolización en la construcción de la "fama" de este personaje, ubicándolo en una esfera que incluso rebasa su condición de "santo" popular.

En este sentido, son diversos los ejemplos para citar. Gabriela Saidón en su "Santos Ruteros. De la Difunta Correa al Gaucho Gil” (2011) reproduce una lista importante de famosos, artistas y periodistas que se han vuelto devotos o que sienten algún tipo de simpatía por la figura y el fenómeno de devoción que genera el Gauchito y que desde sus oficios ayudaron a difundirlo. Menciona desde las obras del artista visual Sergio Gravier hasta las columnas en el que el periodista y conductor Rolando Hanglin se confiesa devoto; desde el documental de Lía Dansker, las obras y relatos de los artistas Karina El Azem y Dani Barreto a la periodista Miriam Lewin que se considera una peregrina más, entre otros. En el mismo texto, Saidón referencia al antropólogo Alejandro Frigerio quien señala que fueron los periodistas quienes empezaron a "ver con simpatía" a los santos populares hacia la década del noventa "luego de tratarlos como superstición" y en ese marco colaboraron en la difusión de la devoción de Gil (Saidón, 2011: 114).

El artista plástico Dani Barreto, que realizó numerosas producciones inspirado en la figura del Gaucho Gil, resalta en el film "El último refugio" dirigido por Pablo Valente (2011) cómo se vio "encantado" por la historia militar que atraviesa la leyenda más difundida de este personaje. También rescata la estética y la visualidad de los altares a los que califica como "hechos artísticos" producidos por los devotos. Un concepto similar manejan otros artistas interesados en las prácticas de la festividad del ocho de enero a las que ven directamente como "performances artísticas". La leyenda del "santo marginal", una especie de Robin Hood "que le sacaba a los ricos para dar a los pobres" y su particular estética de rojo saturado es también lo que lleva a Tomás Larrinaga y Ricardo Becher a realizar "El Gauchito Gil, la sangre inocente" un film que se proclama como un manifiesto del Neoexpresionismo digital del cine argentino (Barrios, 2013).

Los ejemplos podrían continuar, sin embargo importa resaltar que los fotógrafos cuyas obras se abordan (Faccioli, Rusconi, Longoni, Izuel y López) comentan también sobre ese "encanto" especial que les genera personalmente y profesionalmente la festividad y la imagen del gaucho (se repite el particular interés por la historia y la visualidad del fenómeno). Todos admiten una "simpatía" y aunque ninguno se califica como devoto, algunos confirman que le 
piden y le agradecen favores. Es decir, a nivel personal establecen un lazo particular con la divinidad, una relación que discurre entre el sentimiento de simpatía y la creencia. Por otra parte, desde lo profesional todos admiten que el componente de impacto visual y gestual de la devoción, su profuso barroco y la fuerza representacional de la figura del gaucho como símbolo identitario de la Argentina, resultan elementos altamente fotográficos.

Siguiendo a Martin, el Gaucho Gil puede además ser considerado dentro de la lista "seres extraordinarios", junto a Eva Perón, el Che Guevara, Gardel o la misma Gilda, entre otros, a los que se le atribuyen "dones" y un "carisma" que los destacan "de su contexto social, étnico y estético de origen" y los vuelven disponibles, para ser apropiados. "En esas apropiaciones, en la acción de una contraparte humana, adquieren forma, múltiples significados y, así, se completan” (Martin, 2008).

La conjetura de la socióloga es central para entender que las cualidades atribuidas a estos "seres" no le son intrínsecas sino que se construyen mediados por la agencia de los sujetos que le dotan de diversos sentidos e identidades. Ello, a su vez, se basa en el trabajo de los distintos dispositivos, sistemas de representación, que propician el pasaje de las prácticas a los discursos desde posiciones y contextos que sobrepasan los dominios religiosos. En estos procesos de apropiaciones múltiples es donde particularmente nos interesa describir la migración de sentidos entre las re-presentaciones visuales; así como los usos y funciones que les otorgan estos sujetos a las imágenes en su vida semiótica.

En este sentido y volviendo al planteo inicial, encaramos el análisis de las imágenes del Gaucho Gil entendiendo que: la movilidad y los diversos sentidos que adquieren las representaciones fotográficas en su circulación cultural- discursiva hacen a la contingencia y la des-estabilización de sus identidades.

En resumen, -más allá de las líneas de lectura trazadas por Martin sobre el abordaje de la religiosidad popular y en un contexto signado por la "diversificación religiosa", un “campo religioso heterogeneizado" en la Argentina (Segato, 2007 y 2008; Semán, 2013) - se advierte que desde enfoques diferentes buena parte de los investigadores de los temas "religiosos" discuten la construcción de concepciones y categorías analíticas más inclusivas. Ensayan nociones para dar cuenta de los procesos de articulaciones que plantea este campo y sobre todo posibiliten atender la dimensión experiencial y práctica de las devociones. En este sentido, algunas indagaciones incluso plantean la necesidad de abordar los "estados pasionales de fe" desde los procesos de re-memoración (Bondar, 2011; 2013); y las formas de espiritualidad de la "nueva era" o las "nuevas religiosidades" (Viotti, 2011) que aparecen 
imbricadas con las formas religiosas tradicionales y con prácticas y discursos que exceden estos ámbitos.

En este marco, las referencias teórico-metodológicas aquí adoptadas apuntan a atender, desde una mirada situada en los complejos entrecruzamientos de cosmovisiones, prácticas y re-presentaciones que plantea el caso abordado, aquello en lo que insiste Segato:

\footnotetext{
“...ver cómo tendencias extrarreligiosas del contexto histórico social y económico más general afectan el campo religioso, y cómo las adaptaciones internas de éste, a su vez, ejercen su impacto reforzando y suplementando esas tendencias de la historia, que van mucho más allá de los confines del campo estrictamente religioso" (Segato, 2008)
}

En otras palabras, lo que nombra el debate en torno a las nociones de "prácticas religiosas" o de "prácticas de sacralización"; ámbitos de "religiosidad popular", o "religiosidades", es la trama de disputas que presenta el propio "campo religioso heterogeneizado" que, al decir de Semán, es un espacio donde “contemporáneamente, compiten el consuelo de la cruz, la promesa de sanación, las búsquedas interiores a través de la dieta y los ejercicios respiratorios"; y también donde "se apuntalan, expresan y refuerzan no solo definiciones de la religión" sino también "nociones de persona y alteración de las que las 'religiones' son un elemento co-participante” (Semán, 2013).

\section{Hacia un enfoque de análisis relacional transdisciplinar y contrastivo}

A partir de los planteos que hiciera décadas atrás Jesús Martin-Barbero acerca de la necesidad de que la investigación del campo de la comunicación en América Latina se ocupe de las mediaciones, surge la necesidad de pensar en la fotografía del mundo del Gaucho Gil como instancias donde se producen mediaciones múltiples.

De allí, consideramos relevante centrar el análisis en el cruce de las teorías latinoamericanas de la comunicación (Martin-Barbero, 1988, 1989 y 1998; Reguillo, 2008; Caggiano, 2012), los estudios culturales y los estudios visuales (Hall, 2010; Hall y Evans, 1999; Appadurai, 2001; Mirzoeff, 2003; Mitchell, 2003; Moxey, 2009; Guash, 2003) que configuran los debates del emergente campo de la Cultura Visual; a los que contribuyen diferentes planteos de la semiótica (Barthes, 1989; Dubois, 2008); la historia del arte y de la fotografía (Marin, 2009; Didi Huberman, 2006, 2009; Ginzburg, 2008; Tagg, 2005; Freund 1993; Giordano, 2008) y la antropología visual (Belting, 2007; Buxo i Rey, 1998, Poole, 2000) aportando categorías de análisis de la fotografía y del acto fotográfico en sus instancias de producción, circulación y consumo (Hall, 2010) . 
Si bien, poner en diálogo estas disciplinas implica la configuración de perspectivas afines y también des-encontradas en torno al campo de análisis, el entramado de visiones que recuperamos tiene como finalidad llevar adelante un abordaje de carácter poliédrico $^{61}$ que se concibe a partir de una mirada relacional y transdisciplinar; intentando responder a la condición multidimensional de la fotografía en vinculación a las prácticas y procesos culturales que le otorgan sentido. De este modo, las imágenes materiales visuales y las prácticas de fotografiar y re-presentar a través de la imagen configuran objetos complejos que no se entienden de manera aislada sino como un punto de articulación a través del cual es posible reflexionar sobre hechos socio-culturales más amplios.

En este marco, hablamos de la fotografía como "un objeto de identidad ambigua e inestable" que actúa según los sentidos que los sujetos le invisten en el seno de las prácticas culturales y discursivas en función de regímenes de valoración, intereses, formaciones históricas-culturales y posiciones intersubjetivas específicas (Barrios y Giordano, 2015). Las peculiaridades de las dimensiones y roles que definen a la imagen en la producción y reproducción cultural presentan múltiples desafíos para esta investigación.

Particularmente, en el caso de las re-presentaciones fotográficas del Gaucho Gil, aquellas vinculadas a la festividad central del 8 de enero en Corrientes como a las diversas formas de apropiación de la figura de Antonio Gil desde la fotografía en contextos extrareligiosos, apuntamos a reflexionar sobre las siguientes dimensiones: documentalestestimoniales; creativas y artefactuales; la captura fotográfica/performance fotográfica desde la noción de imagen-acto $\mathrm{y}$, finalmente, sus artistas agenciales y performativas, todas vinculadas a las instancias de producción, circulación y consumo.

La aproximación a dichas dimensiones se presenta como una vía de aproximación entre las inagotables formas de interpretación posibles a las que se pueden asociar estas imágenes. También, en base a ellas se construyeron las categorías teóricas-conceptuales expuestas en el Capítulo 1 y en vinculación con los debates desarrollados en el mismo se diseñaron los ingresos de lectura al análisis que se desarrollan en los capítulos de análisis de corpus de imágenes y actos fotográficos específicos que siguen

En ese entramado, la tesis indaga en los modos en que estas dimensiones se solapan, se sobreimprimen dando lugar a la interpretación de la re-presentación fotográfica como prisma complejo de lados/dimensiones heterogéneas, puntos de intersticio, espacios de

${ }^{61}$ En torno la mirada poliédrica de la fotografía se publicó recientemente un dossier con algunos aportes de los principales referentes del campo en el $\mathrm{N}^{\circ} 10,2015$ de la revista Fotocinema, bajo el título "Miradas convergentes: la fotografía y sus interpretaciones en Humanidades y Ciencias Sociales". Disponible en: http// $\mathrm{http}: / / \mathrm{www} \cdot$ revistafotocinema.com. 
articulación donde pueden observarse el entrecruzamiento de huellas provenientes de matrices de la cultura popular-masiva ${ }^{62}$, la imbricación de marcas de lo local, lo nacional y lo global; así como el cruce experiencias de encuentros entre fotógrafos y fotografiados, posiciones y relaciones de poder, hecha de diálogos, tensiones y negociaciones, que cumplen un rol activo en la dinámica de fijación y des-estabilización de memorias e identidades.

En resumen, el enfoque de análisis al que adherimos es aquel que, entendido luego de una serie de rupturas epistemológicas ${ }^{63}$, entre ellos el giro lingüístico y el giro icónico inserto en la era de la mediación visual de la experiencia ${ }^{64}$ y el viraje de los estudios de comunicación "de los medios a las mediaciones", nos permite debatir acerca de la polisemia de los significados que articulan y vehiculizan las imágenes, el problema de la autoría, el contexto, los modos de mostración, circulación y consumo (Guasch, 2003; Hall, 2010; Hall y Evans, 1999).

El desglose de este enfoque nutrido por diversos aportes implica, en la línea de los estudios culturales, entender tanto a los actos/ prácticas de fotografiar y a las formas fotográficas en circulación como espacios de construcción de los contextos y modos específicos de la vida humana; es decir re-presentaciones que "participan en forma constante en la producción permanente de la realidad" (Grossberg, 2012:40).

Lo expuesto supone la adopción de una perspectiva de abordaje construccionista. Si bien, el enfoque no niega la condición material de una realidad -como por ejemplo la especificidad física-material de una fotografía- no adhiere a que esa materialidad se pueda comprender escindida de su formación simbólica-discursiva; dimensión que, a su vez, da cuenta de un contexto de relaciones de fuerza y de poder que define las prácticas discursivas y

\footnotetext{
${ }^{62}$ Dice Martín Barbero: "Matriz no es evocar lo arcaico sino hacer explícito lo que carga el hoy (...) Indagar no lo que sobrevive del tiempo (...) sino lo que hace que ciertas matrices (...) sigan secretamente conectando con la vida de la gente" (Martín Barbero, 1988: 137). Asimismo, el autor invita a pensar lo popular en el campo de la comunicación en su especificidad en diálogo con sus matrices culturales-históricas y desde la experiencia de los sujetos consumidores y productores y no por fuera de lo masivo (Barbero, 1988, 1989 y 1998; Rodríguez, 2010).

${ }^{63}$ Al respecto puede consultarse el artículo De giros y sus relatos. Fragmentos y digresiones de Marcelino García (2010).

${ }^{64}$ Ambos giros son centrales en nuestro planteo. El primero, en los años sesenta, como señala Hall (2010) marcó el enfoque construccionista de la representación, el descubrimiento de la discursividad que sin embargo para algunos críticos habría derivado en un "fetichismo textual" (Said, 2004). El giro icónico (tanto de la escuela alemana como estadounidense) en los años noventa reaccionará contra este fetichismo y la esencialización lingüística del análisis de las imágenes y advertirá sobre la pérdida de reflexión de el carácter "presentativo" de las imágenes (Mitchell, 2003). Estos debates se insertarán en los estudios de la denominada Cultura Visual, que retomando los planteos del ensayo de Walter Benjamin, sobre la obra de arte en la era de la reproductividad técnica, Guy Debord sobre la sociedad del espectáculo, reivindicarán actualmente el análisis de la visualidad y la contra-visualidad, poniendo el acento en la mediatización y la mediación visual de la experiencia.
} 
no discursivas de la producción cultural. Desde este punto de vista, investigar sobre el papel activo de las practicas de fotografiar y la circulación de las imágenes en la construcción de lo social (Mitchell, 2003) requiere hacer hincapié en el concepto de "articulación" que desde los estudios culturales y de la comunicación supone un análisis relacional y transdisciplinar.

En este sentido y a la luz de los recorridos de lectura realizados, este trabajo propone pensar la re-presentación fotográfica desde su dimensión performática como articulación de formas de ver y dar(se) a ver ${ }^{65}$, donde importa ver cómo los sujetos (fotógrafos, fotografiados) reproducen posiciones que manda regulación normativa pero asimismo las confrontan proponiendo otras formas de ver(se) y dar a ver el mundo del Gaucho Gil.

En este sentido, el enfoque de análisis parte de un diálogo de perspectivas con el acento puesto en la imagen y su inserción/ intervención en la producción de procesos culturales específicos. Con ello se apunta a entender los fines para los cuales fue creada, los sentidos que se les atribuyen y hasta qué punto son funcionales a estos fines; pero también observar los modos en que las imágenes "escapan”, como dice Moxey (2009), a esos significados atribuidos cobrando nueva vida y nuevos sentidos, muchas veces inimaginables para sus creadores, a través del tiempo.

El fenómeno de desplazamiento de las fotografías y sus sentidos cobra aún más relevancia en nuestra indagación en el contexto de la globalidad de la cultura y la economía, de la configuración de "identidades en diáspora" y la reconfiguración del "trabajo de la imaginación social" a partir de los flujos migratorios y la movilidad acelerada las imágenes; en el marco de la mediación masiva transformada por los medios electrónicos (Hall, 2010; Appadurai, 2001, Mirzoeff, 2003). Desde estos procesos, antes referenciados, el análisis exige una mirada relacional porque el objeto ambiguo de la imagen, así como los actos fotográficos, no admiten ser considerados de manera aislada sino como "un ensamblaje estructurado de prácticas - una formación cultural, un régimen discursivo- que ya incluye prácticas discursivas como no discursivas" (Grosssberg, 2012: 42).

Esta orientación metodológica implica a su vez, en términos de Stuart Hall, un "contextualismo radical", que se manifiesta en contra de las posiciones esencialistas y universalistas. En dichas posiciones todo está predeterminado, "las respuestas están garantizadas y todo se sutura de antemano" y, justamente la opción relacional implica una lógica "sin garantías" (Hall, 2010; Grossberg, 2012).

\footnotetext{
${ }^{65}$ El concepto es desarrollado en el punto 2 del Capítulo1.
} 
A su vez, el compromiso por el contexto y la singularidad de las relaciones de poder que configuran lo social y, sobre todo reflexionando sobre las prácticas y los discursos en el campo de la comunicación, suponen un abordaje transdisciplinar. Cabe recordar tal como historiza Martin-Barbero, que si bien el campo de los estudios en comunicación en América Latina surge por el "fuego cruzado del paradigma informacional y la teoría crítica", hacia los años ochenta se perciben limitaciones en estos paradigmas. En ese marco se introducen otras propuestas teóricas de abordaje y también los propios procesos trasnacionales y de la globalización exigen la indagación de una "trama nueva de territorios y de actores, de contradicciones y conflictos" (Martin-Barbero, 2002: 215). Con estas demandas surgen los desplazamientos conceptuales y metodológicos del campo hacia un enfoque transdisciplinar basado en las articulaciones que también responde a las requisitorias de un movimiento general en las ciencias sociales:

\footnotetext{
"Se inicia entonces un corrimiento de los linderos que demarcaban el campo de la comunicación: las fronteras, las vecindades y las topografías no son las misma de hace apenas diez años ni están tan claras (...)Desde América Latina ese corrimiento de los linderos del campo se traduce en un nuevo modo de relación con y desde las disciplinas sociales', no exento de recelos y malentendidos, pero definido más que por recurrencias temáticas o préstamos metodológicos por apropiaciones: desde la comunicación se trabajan procesos y dimensiones que incorporan preguntas y saberes históricos, antropológicos, estéticos (...)Al mismo tiempo que la sociología, la antropología y la ciencia política se empiezan a hacer cargo, ya no de forma marginal, de los medios y de los modos como operan las industrias culturales" (Martin Barbero, 2002: 215-216).
}

Asimismo, la tesis opta por un análisis comparativo y crítico de las re-presentaciones fotográficas. Se contrastan las fotos actuales (siglo XXI) con algunas imágenes históricas (siglo XX) y se abordan los cambios y continuidades en la producción de los autores en relación a la coyuntura, la apreciación y aceptación social de las imágenes según el contexto y las distintas posiciones que asume el propio fotógrafo frente a lo fotografiado. La estrategia se desarrolla siguiendo a Caggiano (2012) quien entiende a la contrastación crítica como la única que posibilita la desnaturalización y des-estabilización de los repertorios oficiales que, como bien advierte, se nos manifiestan como dados o normalizados. En este sentido, es posible concebir a las imágenes como escenarios atravesados por relaciones de poder y dominación, disputas de sentido en el juego de las "visualizaciones y ocultamientos, exclusiones e inclusiones, jerarquías y sesgos que organiza las relaciones y posiciones sociales" (Caggiano, 2012: 53). 


\section{Las herramientas de abordaje: métodos, instrumentos y técnicas}

La tesis desarrolla una operatoria analítica relacional, dialógica y contrastiva de las imágenes y de las prácticas fotográficas. Para ello se vale de instrumentos y herramientas específicas del método cualitativo indiciario, el método iconográfico, operaciones analíticas de la semiótica visual y general; así como aportes del método de la "economía visual” y la "lectura performancial" que participa del método etnográfico.

Desde el paradigma cualitativo indiciario propuesto por Ginzburg (2008), se considera la identificación de huellas, indicios que hacen a la particularidad de las prácticas/actos/imágenes fotográficas insertos en prácticas sociales-culturales y discursivas más complejas. Entre ellas, se cuentan aquellas vinculadas al "campo religioso diversificado" donde también las "tendencias extrarreligiosas" - como parte de los contextos y condiciones histórico-culturales de producción y reconocimiento- dejan sus marcas tanto en la configuración de las performances fotográficas - los actos de fotografiar- como en la materialidad de la re-presentación fotográfica puesta a circular en diversos ámbitos.

Asimismo, el paradigma indiciario permite analizar un caso como el elegido (fotos referenciales de la devoción y figura del Gaucho Gil) a partir de imágenes y textos insertos y relacionados a actos/prácticas, situaciones y documentos. Ello pensado desde prácticas culturales y discursivas también "singulares" como las fotoperiodísticas, documentales y artísticas en la que nos enfocamos siguiendo al modo del cazador "los rastros, las huellas, los indicios" que éstas nos revelan. Esta operación de lo "micro" se realiza a fin de sentar las bases para la reflexión de "una realidad más compleja" de "lo fotográfico" en relación con el campo religioso heterogeneizado y las construcciones de memorias e identidades.

Además, el paradigma permite reconocer las imágenes y/o las formas de visualidad de los márgenes que éstas conllevan y no sólo detenerse en la descripción y análisis de las formas en que las fotografías, como artefactos o dispositivos de poder, contribuyen a alimentar los esquemas de dominación. Esta perspectiva cobra fuerza con la noción de "circularidad cultural" que maneja Ginzburg donde plantea la necesidad de tener en cuenta la dicotonomía cultural pero también la circularidad entre cultura subalterna y hegemónica (Ginzburg, 1991). Línea de análisis en la que también insisten los estudios culturales y reflexiones del campo de la comunicación/cultura de Latinoamérica con la mirada focalizada en los procesos comunicativos y las mediaciones ${ }^{66}$.

${ }^{66}$ Las mediaciones configuran las socio-culturales que atraviesan y llenan de sentido a los actos de comunicación, es decir de pensar la comunicación desde los procesos de socialización y reproducción de la 
En este sentido, la reflexión también busca construir una lectura performancial y también procesual de "lo fotográfico" que posibilite abrir el camino a la indagación de los modos de codificación y de-codificación en este caso del hecho fotográfico como producción cultural (Hall, 1980; Buxo i Rey, 1998; Green, 2007).

Esta orientación, desde el punto de vista procedimental teórico-analítico lleva por un lado a aprovechar las potencialidades de la interpretación iconográfica-iconológica (proveniente de la Historia del Arte, específicamente en los desarrollos de Panofsky y Gombrich) que permiten un abordaje de la forma y el contenido vinculado a ciertos documentos de referencia literaria e histórica, y los estilos y las subjetividades del autor; y también a prestar atención a la reproducción o recurrencia de figuras y formas visuales en la producción fotográfica inserta en procesos de circulación y transmisión de la memoria colectiva (procedimientos que alumbraron los estudios de Aby Warburg seguido por Didi Huberman, Burucúa, Ginzburg, entre otros). También se retoman los estudios sobre la iconicidad e indicialidad de la imagen fotográfica en relación a significados culturales, desarrollados también por la semiótica (Peirce, 1897; Barthes, 1989; Dubois, 2008); y las reflexiones de los estudios visuales y culturales y la antropología visual que permiten resaltar las formas específicas en que las imagen generan sentidos en relación a contextos de producción, circulación, consumo (Poole, 2000; Hall, 1980).

Específicamente, los instrumentos tomados de la iconografia-iconología de la historia del arte para el análisis de las imágenes son: 1- descripción formal de la etapa preiconográfica, 2- análisis del significado convencional en relación a literatura, otros textos, de la etapa iconográfica, y 3- el significado simbólico teniendo en cuenta los intereses del autor y su aceptación social. De la semiótica general y la semiótica visual se toman las operaciones de: identificación, reconocimiento e interpretación de la imagen material visual y la relación de éstas formas con los procesos de simbolización más amplios en el campo de producción de sentidos de lo social.

A partir de estas herramientas, se hace hincapié en describir los modos de composición fotográfica; identificar y analizar las huellas de los recortes, los elementos que visibilizan y ocluyen las capturas fotográficas y los esquemas que las fotos actuales reproducen de imágenes pasadas o las rupturas en las formas de representación que plantean, esto último

cultura. En este sentido, Martín Barbero insiste en reubicar la problemática de la comunicación en el campo de la cultura a los fines de "conflictos que articula la cultura, de los mestizajes que la tejen y las anacronías que la sostienen, y en últimas del modo en que trabaja la hegemonía y las resistencias que moviliza, del rescate por tanto de los modos de apropiación y réplica de las clases subalternas” (Martín Barbero, 1998: 240). 
atendiendo al "espesor temporal" de las representaciones, la "historicidad" o memoria de las imágenes. Así también, se atiende a los modos circulación/mostración de las imágenes por campos diversificados, tanto desde soportes-espacios físicos y virtuales; y los sentidos que se le atribuyen en relación a otros discursos y prácticas ancladas a una coyuntura también específica.

En este marco, se atienden las relaciones de las imágenes y las prácticas de fotografiar con las instancias de análisis que postula Poole (2000) desde el método de la "economía visual" proveniente de la antropología visual: 1)- la producción, que contempla tanto a los "hacedores" de imágenes como al contexto social, ideológico y técnico en que surgen; 2)- la circulación, que atiende al aspecto tecnológico de reproducción de imágenes y a los ámbitos de mostración; 3)- la recepción, donde se exploran los sistemas culturales y discursivos a través de los cuales las imágenes son apreciadas, interpretadas y reciben un valor histórico, científico y estético determinado. Siguiendo a Hall (1980), dichas instancias no son concebidas de manera lineal y con límites definidos sino como una compleja estructura de relaciones entre estos momentos de la comunicación ${ }^{67}$.

De este modo, la interrogación en torno a las re-presentaciones fotográficas del Gaucho Gil exige el ensamblaje de textos asociadas a ellas (referencias textuales lingüísticas y especialmente iconográficas de documentación histórica y periodística, así como las notas de observaciones de actos fotográficos en la festividades) a fin de superar el carácter fragmentario que dificulta la lectura de la imagen, para dar paso a una serie de relaciones entre producción, circulación, consumo y reproducción. Ello sin desatender las especificidades agenciales y performativas desde las cuales las cuales "el campo de lo visual construye lo social" (Mitchell, 2003).

Por su parte, del método etnográfico del que participa la lectura performancial de la producción fotográfica contribuye a la descripción del campo y la reflexión de los actos fotográficos. La etnografía posibilita, como señala Guber (2012), "meter los pies en el barro del terreno" - en este caso en la festividad del Gaucho Gil- a fin de entender cómo viven y piensan, cómo sienten, se relacionan y actúan los sectores fotografiados y los fotógrafos. Específicamente para esta tesis se siguió algunas trayectorias de fotografiar de Juan Pablo Faccioli y Guillermo Rusconi en la festividad central del Gaucho Gil, en Mercedes Corrientes.

\footnotetext{
67 Se entiende junto a Hall a la recepción y la circulación como momentos que atraviesan la producción, reproducción fotográfica y su proceso de proliferación; instancias que al igual que el consumo son incorporados mediante un número de retroalimentaciones estructuradas e indirectas en el proceso mismo de producción (Hall, 1980).
} 
El contacto se desarrolla a partir de la comprensión de la fotografía en su dimensión de práctica social. Como herramientas claves en el trabajo de campo se convoca la conversación con los sujetos implicados, entrevistas no estructuradas, e instancias en la que compartimos con los grupos sociales las actividades socio-culturales que se desarrollan; asimismo se utiliza la observación participante para “observar” y “tomar notas” (Guber, 2012).

En suma, las herramientas utilizadas apuntan a reconstruir los contextos, las interacciones entre fotógrafos y fotografiados, la escenificación, la capacidad de agencia de los sujetos retratados ante la cámara, las relaciones con el entorno. Para ello se siguen además planteos teóricos - empíricos ya realizados por Buxo i Rey (1998), Barthes (1989), Bourdieu (2004), Edwards (1992) y Green (2007). En definitiva, el trabajo etnográfico se plantea como una aproximación a la indagación de la foto desde el acto que la produce, una instancia escasamente abordada por las investigaciones existentes. Asimismo las técnicas e instrumentos del método, con sus riesgos y limitaciones, posibilitan reconstruir la esfera "íntima” y "vivencial" del campo significante en el que las prácticas de ver y dar(se) a ver, fotografiar y re-presentar se desarrollan. 
SEGUNDA PARTE:

DEL CASO A LAS APROPIACIONES FOTOGRÁFICAS 


\title{
CAPÍTULO 3:
}

El Gauchito iconográfico y fotogénico: ingresos al caso y a las imágenes

\begin{abstract}
“Como señaló alguna vez Martin Caparrós, 'Antonio Gil es el Interior hecho creencia; Antonio Gil es la gauchesca hecha superstición'. Algo menos despectivamente, yo diría que 'Antonio Gil es la gauchesca hecha religión', una literatura y una simbología que nos siguen identificando, desde las áreas rurales al conurbano profundo y, crecientemente, también en la Capital. Jesucristo y Martín Fierro en una amalgama cuyo nivel de aceptación y destino final es una incógnita, pero que todo indica será cada vez más exitosa",
\end{abstract}

Alejandro Frigerio, Tres santuarios del Gauchito Gil en el conurbano (3)

\begin{abstract}
"Las tendencias de la religiosidad contemporánea responden a un nuevo orden territorial (...) En este nuevo orden, la inscripción performática de la unidad de un grupo humano pasa a tener una importancia que no tenía antes(...) Estos nuevos pueblos, en su movilidad, ya no encuentran en el paisaje tradicional los iconos marcadores de su identidad. Esa relación se invierte, y son los iconos que ellos transportan los que van a emblematizar el sujeto colectivo que allí se encuentra; es el paisaje humano, móvil y en expansión, el que va demarcar la existencia de un territorio"
\end{abstract}

Las diversas historias que se construyeron en torno al Gaucho Gil, con anclaje de origen en la ciudad de Mercedes, provincia de Corrientes, Argentina, a mediados del siglo $\mathrm{XIX}$, se basaron principalmente en la tradición oral. El primer signo material visual de referencia para los promeseros fue una cruz ubicada al costado del camino que marcaba el lugar donde Gil habría sido degollado. Recién hacia fines del siglo XX, entre 1970 y 1980, se anexó la potente imagen escultórica humana de un gaucho sobreimpresa a una cruz como principal inscripción de referencia en el santuario mercedeño. Esta imagen es la que actualmente se reproduce en estampitas, banderas, objetos varios y también es imitada y personificada por los promeseros.

Desde la década del ochenta y principalmente en los años noventa, esa iconografía junto a cintas y banderines rojos, que también conforman distintivos, proliferaron a través de distintas prácticas de reproducción y apropiación cultural, traspasando las fronteras de Corrientes. Lo más llamativo es que hacia los años 2000, ese símbolo se desprende de los espacios dedicados a los rituales religiosos para ser apropiado, con connotaciones diversas, por actores sociales vinculados al mundo del arte, el espectáculo, la publicidad, entre otros. 
De este modo, la figura del Gaucho Gil empezó a configurarse en el imaginario nacional como una de las iconografías más pregnantes de la religiosidad popular argentina.

A los fines de ahondar en la configuración de dicha imagen, este capítulo abre interrogantes y reflexiones sobre la construcción performática y fotogénica $^{68}$ de la representación iconográfica central y del mundo visual del Gaucho Gil, incluyendo a las fotografías; también analiza los modos en que estas imágenes forman parte activa de una serie de sistemas discursivos performativos que, a su vez, operan en la actualización y recreación de memorias y representaciones identitarias ${ }^{69}$. Para ello, se analizan las cualidades formales, expresivas y la densidad histórica de la iconografía central y de las imágenes circundantes, en diálogo con los imaginarios que vehiculizan prácticas sociales y discursivas relacionadas.

En un primer ingreso de lectura, el texto plantea una aproximación a las memorias que construyeron la figura del Gaucho Gil y los trayectos de la expansión de la devoción. En segundo lugar, se historiza la incorporación de la imagen humana de un gaucho crucificado con pañuelo y bincha en tonos rojos como principal símbolo aglutinante de promeseros; también se analiza el modo en que dicha imagen se construye desde la articulación entre lo popular y lo masivo como uno de los signos más pregnantes de la religiosidad popular argentina, llegando incluso a ser considerada un símbolo de la argentinidad, cuyos sentidos sobrepasan el ámbito religioso

El tercer apartado indaga cómo y en vinculación a qué textos la representación iconográfica del Gaucho Gil actualiza matrices de sistemas de creencias tradicionales y mitos fundadores de identidades/alteridades nacionales.

El cuarto y quinto ingreso de lectura reflexionan sobre los elementos que hacen a la extraordinariedad y popularidad de esta figura milagrosa; así como el modo y ligado a qué procesos religiosos, socio-culturales y comunicacionales la imagen de este "santo" popular también se relaciona a esquemas de identificación diferenciales, planteando espacios de complejos mestizajes y de construcción de identidades múltiples.

\footnotetext{
${ }^{68}$ Como ya se dijo en capítulos anteriores, la iconografía del Gaucho Gil tiene ciertos ribetes performáticos y fotogénicos que aquí se intentará desarrollar. La primera dimensión, según Taylor (2012), denota la forma adjetivada de la performance y refiere a la puesta en escena, el carácter teatral o espectacular de un suceso; en tanto el segundo refiere tanto cualidades visuales senso-perceptivas, expresivas como también a la densidad simbólica de la imagen.

69 Aquí la performatividad se diferencia de la performance o lo performático -explicitado en la cita anterior- y refiere a un efecto pragmático del discurso. Es producto de prácticas y normas regulatorias discursivas que influyen en la conformación de las representaciones y de las identidades sociales. Así Judith Butler cuando analiza el género lo entiende como producto de esos sistemas discursivos y performativos (Taylor, 2012; Butler, 2002).
} 
Finalmente, en los últimos dos apartados el texto aborda la manera en que la imaginería del Gaucho Gil junto a las modalidades de vinculación de los fieles con la divinidad, que incluyen inscripciones y demarcaciones identitarias comunitarias-religiosasterritoriales, construyen escenas performáticas y fotogénicas que motivan su apropiación y re-significación desde la práctica fotográfica, en general, y la producción de los cinco fotógrafos especialmente referenciados en esta tesis, en particular.

\section{Memorias del Gaucho Gil: una devoción expandida a la vera del camino}

Antonio Mamerto Gil Núñez, hoy conocido como el Gauchito Gil, según los relatos orales fue un gaucho perseguido por desertar de la milicia en pleno enfrentamiento entre unitarios y federales durante el proceso de organización nacional; y también por estar acusado de robar a viajeros y terratenientes. Un milagro que habría realizado poco antes de morir (salvarle la vida al hijo moribundo de su ejecutor) y por repartir su botín entre los más necesitados dio origen a la leyenda del gaucho milagroso y justiciero.

Los escritos, en su mayoría también apoyados en la tradición oral, ubican el nacimiento y la muerte de este gaucho en Mercedes, provincia de Corrientes, Nordeste argentino, entre 1840 y 1878 . Aunque no existen precisiones en cuanto a las fechas, las versiones de su historia que disparan hacia direcciones sentido diversas alimentan el mito y la veneración popular crece a la vera de la ruta nacional $N^{\circ} 123$ en la zona del paiubre, centro provincial $^{70}$.

Entre los relatos orales y las imágenes que se desprenden de ese escenario de fe, cobra vida una de las leyendas más difundidas: aquella que vincula a Antonio Gil con los tiempos en que la guerra civil hacía estragos en la región. Alrededor de 1875, Gil habría sido reclutado por el Coronel Juan de la Cruz Zalazar para combatir en el enfrentamiento entre unitarios y federales ${ }^{71}$. Atormentado por no querer derramar sangre de "hermanos", el gaucho se habría convertido en desertor. Algunos dicen que un ángel le aconsejó la deserción durante una

\footnotetext{
${ }^{70} \mathrm{El}$ territorio del paiubre toma su nombre de un afluente caudaloso de un rio llamado por los guaraníes Paiubé (paí-entrañas. ú-comer, bé-mas).

71 Eran sectores políticos que proponían dos modelos organización gubernamental nacional. Los unitarios postulaban la necesidad de un gobierno central fuerte y los federales planteaban una asociación voluntaria de las provincias, que delegaban algunas atribuciones al poder central, pero conservaban su autonomía. La simbología de ambas fracciones incluye banderas azules y coloradas, respectivamente. Las leyendas cuentan que el Gaucho Gil era federal y de allí el color rojo que predomina en las ofrendas y su iconografía. El celeste y colorado también son adoptados por el Partido Liberal y el Partido Autonomista (de formaciones rastreables cerca de 1860 el primero y 1870 el segundo), partidos provinciales tradicionales. Así, perdura hasta hoy el uso del distintivo celeste y colorado Corrientes.. Por otra parte, algunos relatos también señalan que Gil luchó durante la Guerra del Paraguay antes de los últimos enfrentamientos internos que desencadenaran su muerte.
} 
visión; otros que fue Ñandeyara (el dios guaraní) quien se le apareció en un sueño. Lo cierto es que vivió al "margen de la ley".

Los devotos indican que era un hombre bueno y noble, que robaba a los ricos para dar a los pobres. En cambio, sus detractores consideran que fue un delincuente, fugitivo y que su trágico final fue merecido. Cuentan también que era invencible en los enfrentamientos porque a su valentía se le sumaba la protección de San La Muerte y Santa Catalina ${ }^{72}$. Por otra parte, otros dicen que era poseedor de una mirada hipnotizante que enamoraba. Algunas literaturas dan cuenta de un romance que habría tenido con una tal Estrella Díaz Miraflores. Según esta versión, el hostigamiento de la policía fue producto de la pasión: se dice que el comisario también pretendía a la enamorada de Gil (Lojo, 2007).

El 6 de enero, posiblemente en 1878, Gil habría asistido a la fiesta de San Baltasar en la casa de Zía María ${ }^{73}$. Muchos presumen que la traición de un conocido provocó su captura y que él se entregó sin resistencia. El policía recibió la orden de llevarlo a Goya para la sentencia, pero en el camino, en las afueras de la ciudad de Mercedes, decidió degollarlo.

"No me mates, que ya va a llegar la carta de mi inocencia (...) Cuando llegue la carta vas a recibir la noticia de que tu hijo está muriendo por causa de una enfermedad; cuando llegues rezá por mí y tu hijo se va a salvar (...)”, habrían sido aproximadamente las últimas palabras de Antonio Gil, tal vez, un 8 de enero de 1878. Cuando la policía llegó a Goya, descubrió que Gil había sido perdonado. El sargento que lo ejecutó fue hasta su hogar y vio que su hijo estaba al borde de la muerte y acordándose de las palabras de Gil, le imploró perdón y ocurrió el primer gran milagro de la historia legendaria: recuperó a su hijo moribundo. En señal de agradecimiento, regresó al lugar de la ejecución y erigió una cruz de madera de ñandubay (espinillo).

Al costado de la vía, lo que primero fue una sencilla cruz hasta donde los lugareños llegaban para prenderle velas, se transformó en un gran santuario. Este oratorio marca el sitio

\footnotetext{
${ }^{72}$ También llamado Nuestro Señor de la Muerte, San Esqueleto, San Severo de la Muerte, entre otras nominaciones, la leyenda de San La Muerte condensa historias de matrices también diversas. Se dice que era un monje revelado de la misión de evangelización colonizadora que fue aprendido y murió tras un largo ayuno; otros que era un chamán guaraní. Lo cierto es que es muy venerado en América del Sur y especialmente en el litoral argentino. Sus imágenes talladas en madera o hueso, que en general suelen ser incrustadas debajo de la piel, sirven de amuleto para el amor y la buena fortuna y protección ante los maleficios y la muerte. Su imagen calavérica parada con guadaña en mano y otra versión que aparece a veces sin guadaña sentada que se asocia a la imagen del Señor de la Paciencia, se difundió desde fines de los años sesenta asociada a la figura del Gaucho Gil. Santa Catalina es protectora de las personas en trance de muerte.

73 Desde aquí el imaginario del Gaucho Gil, además de su matriz guaraní de fuerte raigambre por las comunidades indígenas que poblaron la región, la cercanía y el intercambio socio-cultural constante con Paraguay; así como las matrices españolas colonizadoras y de las posteriores vertientes de migración europea del siglo XIX y XX, se "cruza" también con la cultura de afro, cuya población e influencia socio-cultural en la formación de las identidades fue in-visibilizada con el proyecto de "blanqueamiento" de la nación argentina.
} 
donde muriera Gil degollado en manos de la policía un 8 de enero. Se trata de un lugar cubierto de cintas y banderas rojas, pancartas, íconos religiosos diversos y productos de la industria cultural en el seno de edificaciones comerciales dispuestas en hilera a los costados de la ruta nacional 123, kilómetro 111. Allí, en el día del aniversario de la muerte de esta figura popular, miles de devotos realizan una gran festividad para recordarlo, pedir y agradecer favores.

Si bien, las diversas historias que construyeron al Gaucho Gil -memorias inventivas, contradictorias, conflictivas, algunas más o menos consensuadas- tienen anclaje geográficotemporal de origen en Corrientes a mediados del siglo XIX, recién hacia fines del siglo XX la devoción se difundió en todo el territorio nacional y algunos poblados de los países lindantes.

La concurrencia masiva de fieles en el santuario mercedeño se acentúa en los años ochenta. A fines de los noventa se contabilizan alrededor de 50 mil personas en la festividad del 8 de enero (Dri, 2003). Mientras que hacia la primera década de los años 2000 la convocatoria rondar las 250 personas, estimándose la concurrencia de 600 y 700 mil personas entre los días 6 al 8 de enero ${ }^{74}$.

En tanto, la expansión de la devoción a nivel nacional aparece como un proceso fuertemente signado por la visibilización de diversificación religiosa y la aparición de nuevas canonizaciones populares -entre los que se cuentan los casos de Gilda y Rodrigo- que atraen multitudes y alcanzan una importante difusión mediática ${ }^{75}$.

Particularmente, la divulgación de la figura del Gaucho Gil se sostuvo en gran parte en la acción de los promotores del "santo" y la creación de la iconografía del gaucho sobreimpresa a una cruz como signo de identificación de la devoción jugó un rol central en su visibilidad. Se estima que esta imagen aparece entre la década del setenta y del ochenta (así lo confirman varios testimonios), colaborando en la proliferación de promeseros y simpatizantes a lo largo y ancho de todo el país. Esta iconografía reemplazó al primer signo visual, el Curuzú (cruz en guaraní) Gil y empezó a funcionar en espacios rituales específicos (santuarios, altares) de sustituto (en tanto Antonio Gil se vuelve presente en la imagen a través de la invocación o el rezo) y también como símbolo asociado a la dimensión mítica que actualiza.

\footnotetext{
${ }^{74}$ Estos datos aparecen en diversos medios periodísticos y en las consultas personales realizadas a los jefes de los operativos de seguridad en el santuario de Mercedes entre 2010 y 2012.

75 Ver más al respecto en el apartado 4 del presente capítulo.
} 


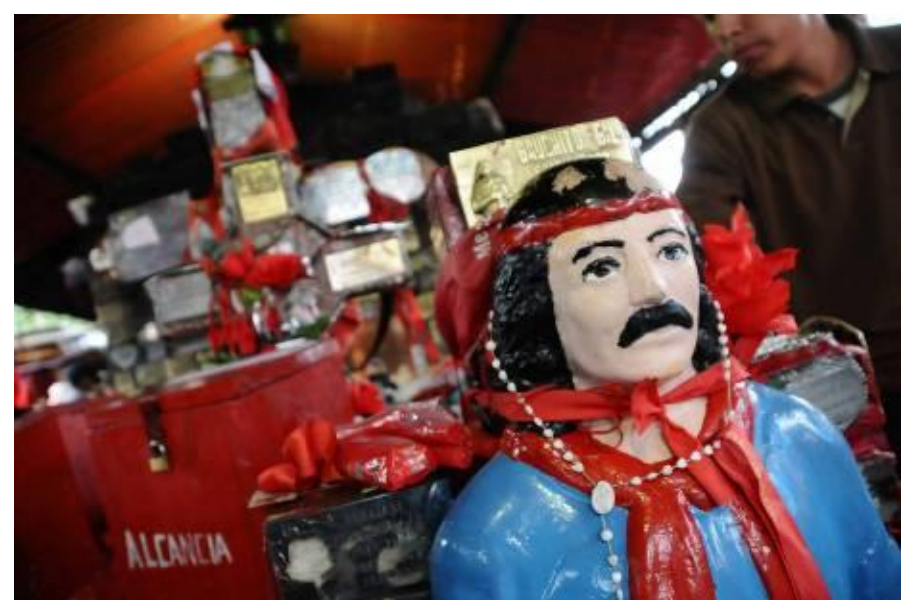

Juan Pablo Faccioli. S/T. Mercedes, 2009. Col: Faccioli. Publicado en Agencia Corrientes 8/1/12 y Flickr del fotógrafo. Escultura central del Gaucho Gil en el santuario de Mercedes. Se encuentra donde se cree fue sacrificado y hasta donde miles de fieles se movilizan año a año. Una alcancía y una tumba recubierta de placas se observa detrás. El cuerpo sin vida de Antonio Gil habría sido trasladado al cementerio mercedeño, donde también las banderolas rojas distinguen su sepulcro, aunque este no presenta la concurrencia del santuario rutero.

Por otra parte, la imagen también sirvió como un "ícono-emblema"76 diferenciador de fieles. Especialmente en el marco de las migraciones de devotos correntinos al Gran Buenos Aires y otros puntos del país el ícono se reprodujo junto a fragmentos de leyendas y testimonios de milagros y a través de diversos medios. Además de esta imagen, las propias cintas y banderines impresos en color rojo, como aquellas que adornan su santuario central y que se visibilizan en numerosos altares ruteros, comenzaron a tomar forma de distintivo.

De este modo, principalmente entre mediados de la década de 1990 y los años 2000, a través acciones espontáneas y rituales de re-memoración, fuertemente anclados en procesos migratorios internos ${ }^{77}$ y a la configuración de «identidades en diáspora» ${ }^{78} \operatorname{los}$ devotos llevaron el culto más allá de la frontera correntina a través de la imagen de Gil impresa en sus atuendos, vehículos e incluso en la piel. También instalaron altares en sus hogares y principalmente a los costados de las rutas del país. De allí que, además de ser identificado

\footnotetext{
${ }^{76}$ Hacemos alusión a un término utilizado por Segato $(2007 ; 2008)$ en referencia a la "heráldica" de grupo que comunidad construye y a partir de la cual ejerce la reconfiguración de territorialidades e identidades en el pasaje. Concepto que se retoma en el último apartado de este capítulo.

${ }_{77}$ Hablamos de migraciones de correntinos asentados principalmente en el Gran Buenos Aires durante la industrialización surgida con el primer gobierno de Domingo Perón desde la década de 1940 con intervalos hasta la década de 1970 y principalmente una segunda ola importante producida desde mediados de la década 1990 hasta el fin de la convertibilidad en 2002 en medio de una de las últimas crisis económicas y sociales más importantes de la Argentina que es cuando más se visibiliza la adhesión a la devoción al Gaucho Gil en el Conurbano bonaerense.

${ }^{78}$ La conceptualización desarrollada por Stuart Hall es retomada aquí al considerar la relevancia de los flujos migratorios internos como uno de los factores determinantes del desplazamiento de los cuerpos y de los símbolos asociados a la devoción del Gaucho Gil. Más sobre el concepto mencionado. Ver: Stuart Hall "Identidad cultural y diáspora", en Sin garantías. (Ecuador: Envión Editores, 2010) 349-362.
} 
como "el santo de los desposeídos"79, o ser llamado despectivamente el "santo de los delincuentes" $" 80$, en los últimos tiempos se lo conoció como el santo de los camioneros o "el santo rutero" (Saidón, 2011).

Así, la figura del Gaucho Gil empezó a configurarse en el imaginario nacional como uno de los símbolos más pregnantes de la religiosidad popular argentina. También asociada a diversos procesos de apropiación, la re-presentación iconográfica central de este "santo" adquirió diversos sentidos llegando incluso a ser considerada por intelectuales del campo académico y de la producción artística como un símbolo de la argentinidad ${ }^{81}$.

\section{Del Curuzú Gil al Gaucho Gil: el espesor histórico del icono popular-masivo}

Durante trabajo de campo realizado en Mercedes y la indagación de las fotografías que forman el corpus central de análisis, pudimos observar que además de los relatos orales, en la devoción al Gaucho Gil también cobra vital relevancia el culto a la imagen. Logramos ver que la mayoría de los promeseros portan imágenes de bulto o estampitas en el auto, en la billetera, inscriptas en la vestimenta o tatuadas en la piel que median en su relación con la divinidad. La imagen preponderante en todas las escenas de exhibición ritualizada presenta la figura humana de un gaucho, más pampeano que correntino, de chiripá, con boleadora en manos, pañuelo y bincha roja y camisa celeste, sobreimpreso a una cruz.

Llama la atención como dicha iconografía, más allá de su inserción en retóricas mediáticas, se difunde a través de los cuerpos, las indumentarias, la instalación de altares en los caminos públicos y los espacios privados; y también el modo en que, en determinados contextos y dentro rituales específicos, la imagen participa activamente en la construcción de eventos performativos (hechos de peticiones, promesas y ofrendas) que se plantean como

\footnotetext{
79 Esta denominación cobra fuerza con un titular del suplemento del diario La Prensa que así identifica al Gaucho Gil en 1980.

${ }^{80}$ Esta identificación es construida desde discursos en su mayoría mediáticos con acentuaciones despectivas. Se trata de textos que hablan de un crecimiento de la devoción al Gaucho Gil profesada por personas privadas de su libertad acusadas de diversos delitos. La imagen de este "santo" prolifera en las cárceles junto al de San La Muerte a quienes los fieles en contexto de encierro acuden por "protección". Sin embargo, como advierte la socióloga Cecilia Galera, el encasillamiento de esta devoción al espacio carcelario o delictivo es cuestionable teniendo en cuenta que se trata de un "fenómeno complejo, dinámico, con un potencial creativo donde se mezclan y adaptan tradiciones religiosas diversas y cada santuario funciona como un centro autónomo de devoción donde se brindan conocimientos y prácticas que no están regulados o centralizados de ningún modo" (Galera, 2014).

${ }^{81}$ En este sentido, se cuentan los escritos del antropólogo Alejandro Frigerio y las intervenciones artísticas y las opiniones del fotógrafo Marcos López, entre otros.
} 
escenas estructurantes de la devoción y de la cultura local ${ }^{82}$. Sin embargo, vale señalar que esta imagen no siempre fue la representación central la devoción. Varios testimonios coinciden en que el signo que nucleaba a los seguidores de Antonio Gil hasta mediados del siglo XX era una sencilla cruz enclavada al costado del camino que marcaba el lugar donde murió el gaucho, presuntamente un 8 de enero, y que los campesinos visitaban y adornaban con tacuaras envueltas en cintas y banderas celestes o coloradas.

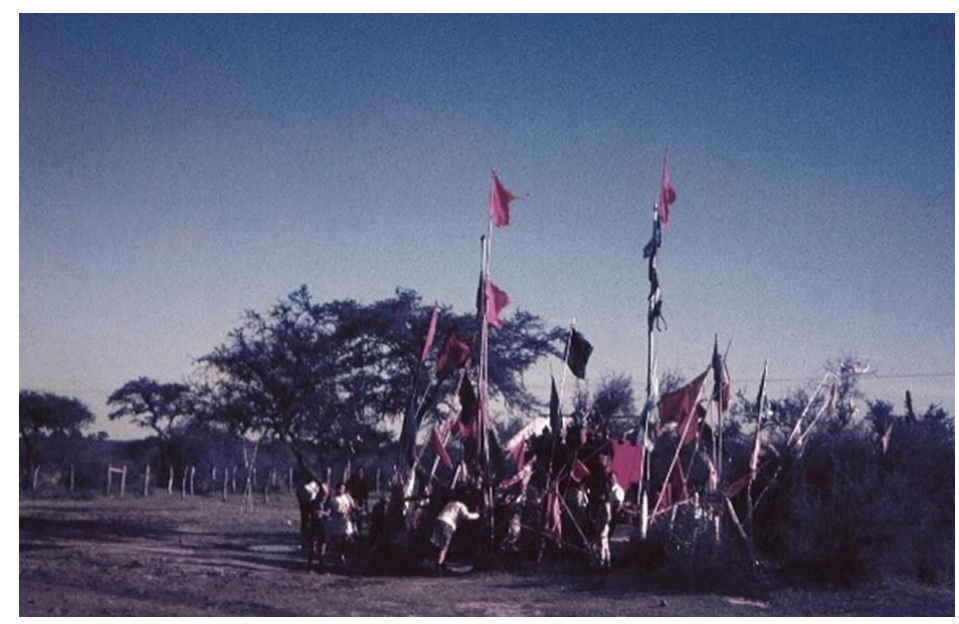

Ermita de la Cruz Gil, hoy Santuario del Gauchito Gil, ya predominaban las tacuaras enarboladas por banderas rojas. Toma de la década de 1960. Autor Desconocido. Foto recuperada por Omar Mónaco.

Según los relatos, el celeste y el colorado, en tiempos de la vida de Antonio Gil, aludían a la simbología de los unitarios y federales y actualmente identifican a los partidos políticos tradicionales de Corrientes (Liberal y Autonomista). Pero con el tiempo, en las prácticas de veneración del "santo" popular y en las representaciones asociadas predominó el rojo. Augusto Cabrera, devoto e integrante de la agrupación los Gauchos de Antonio Gil, que encabeza la cabalgata de la fe en enero como una ofrenda de "gauchos a otro gaucho", nos brinda más datos al respecto:

\footnotetext{
"La primera cabalgata se hizo en 1983, éramos 17 jinetes, ahora somos como 400. Nosotros pensamos ¿por qué habría que realizarse una caravana en auto? Nos preguntamos ¿por qué no la realizamos a caballo? Entonces rápidamente creímos que como él era un gaucho, era mejor hacerle justamente una ofrenda de gaucho a gaucho (...) Antes de la peregrinación a caballo, cuando el lugar estaba rodeado
}

\footnotetext{
${ }^{82}$ Estos "eventos performativos" refieren a lo que el antropólogo Milton Singer (1972) denomina "performances culturales" y se utiliza para describir actuaciones particulares como las bodas, celebraciones en templos, recitales, obras de teatro, danzas. La devoción al Gaucho Gil se propaga entre sus adherentes a partir de conductas ritualizadas, formalizadas, o reiterativas que devienen en ritos. Ellos implican pasos a seguir para conseguir efectos pragmáticos donde la imagen cumple una función de sustituto y símbolo. Estos eventos pueden considerarse performativos en tanto constituyen mecanismos de producción social que transmiten valores, construyen memoria e identidades comunitarias (Turner, 1988).
} 
por alambre de púa, los paisanos preparaban tacuaras a las que se ataban las banderas celestes o coloradas para poder acercarlas al monolito" 83

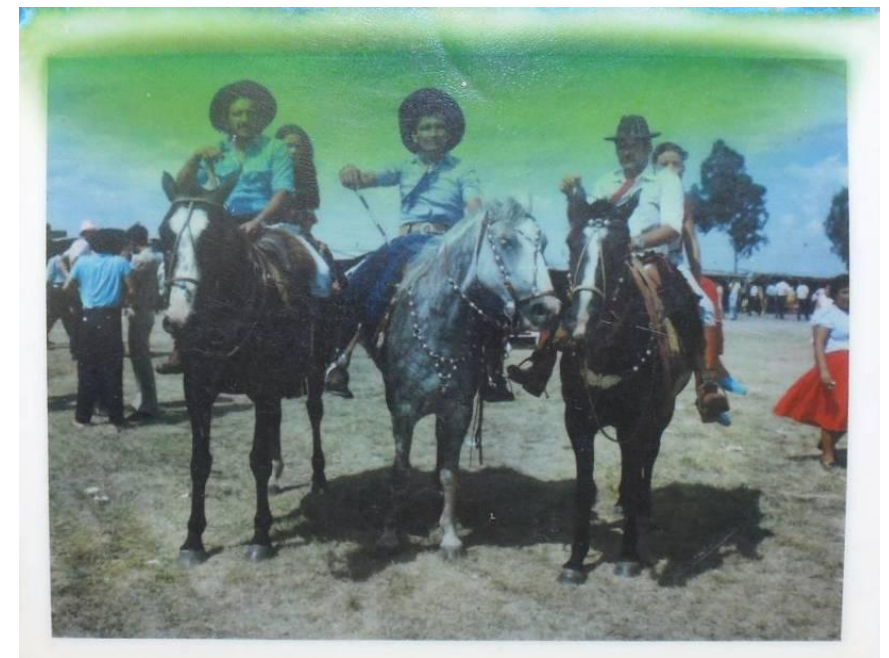

Integrantes de la Agrupación Gauchos de Antonio Gil ataviados con vestimenta celeste y colorada. Tomada alrededor de la década de 1980. Foto del álbum familiar de Augusto Cabrera.

Así también se lee en los relatos que reproduce Saidón (2011) de José López, hijo del ex presidente del Centro de Devotos de la Cruz Gil, quien ayudó a difundir la figura del gaucho en Buenos Aires. El entrevistado afirma que "el gaucho era celeste" pero después ganó el rojo que era el color que se le asignó a las cintas y objetos recordatorios comercializados. Según López se eligió ese color porque "era el color que se usaban para las cosas que vendían más nomás” (López, en Saidon, 2011: 95). Por su parte, otra entrevistada de la escritora, Elba, asegura que "hacia fines de la década de 1960, un político correntino había hecho una promesa: 'que si ganaba las elecciones locales, iba a hacerlo todo de rojo al Gaucho, que entonces era celeste. El político ganó y sacó todo el celeste” (Elba, en Saidón, 2011: 100).

En términos generales, las re-memoraciones en contraste presentan versiones muy diversas; algunos sostienen también que el rojo tiene que ver con la filiación federal del gaucho en tiempos de la guerra civil y otros tantos dicen que prevaleció ese tono como símbolo de la sangre derramada, el valor, la rebeldía.

En cuanto a la anexión de la figura humana del gaucho crucificado, en una entrevista brindada a Página/12 el intelectual correntino Carlos Lacour recuerda que la cruz era denominada Curuzú Gil hasta que en los años '50 y '60 “pasó a ser conocida como Cruz Gil (...) Mientras que la imagen del Gauchito Gil que conocemos ahora surgió a mediados de los

${ }^{83}$ Comunicación personal en diciembre de 2010. El subrayado es nuestro. 
sesenta. Pero siempre fue el mismo símbolo que fue cambiando, tanto de imagen como de nombre" 84 .

Según Lía Dansker, directora del documental Antonio Gil (2013), quién registró y recolectó relatos durante diez años en la festividad de Mercedes (2000-2010), habría sido Antonio López, ex presidente del Centro de Devotos de la Cruz Gil quien en los ochenta mandó a realizar la imagen del gaucho que hoy se conoce en el santuario ${ }^{85}$. Aunque no existen precisiones al respecto, parecería ser que la familia López fue una de las que colaboró en la difusión del culto fuera de Corrientes, valiéndose de la reproducción iconográfica acompañada de leyendas. "Las primeras cintas la hizo mi madre en casa (...) Mi papá empezó a llevar al Gauchito a Buenos Aires (...) vendíamos velas, cintas (...) La comisión tenía las camisetas del Gauchito. Y se hacían remeras, se les ponía Gracias Gaucho Gil por las promesas cumplidas”, relata José López en su entrevista con Saidón (2011).

De este modo, la incorporación de la imagen humana de un gaucho a la originaria Curuzú Gil aparece como un elemento relevante en la historización de la devoción no sólo porque se instituye en el santuario como inscripción central sino también porque la figura comienza a reproducirse en una serie de objetos recordatorios que se comercializan hacia los años ochenta y principalmente en los noventa en otros puntos del país.

Para Gentile, quien sigue las lecturas de Coluccio, Chertudi y Newbery, entre otros, este proceso de difusión configuró a fines del siglo XX una nueva la organización y relanzamiento del culto "usando las técnicas del mercado vigentes". La investigadora indica que la ampliación de la "escueta biografía" del gaucho, así como la asignación de la mencionada imagen y el desarrollo de "una industria de fabricación de objetos" fueron centrales en la propagación de la figura popular, que luego termina imponiéndose a través de su reproducción mediática (Gentile, 2013).

\footnotetext{
${ }^{84}$ Entrevista Página/12, 6 de enero 2011 Disponible: http://www.pagina12.com.ar/diario/dialogos/21-1597352011-01-03.html

${ }^{85}$ Comunicación Personal en Abril de 2013.
} 


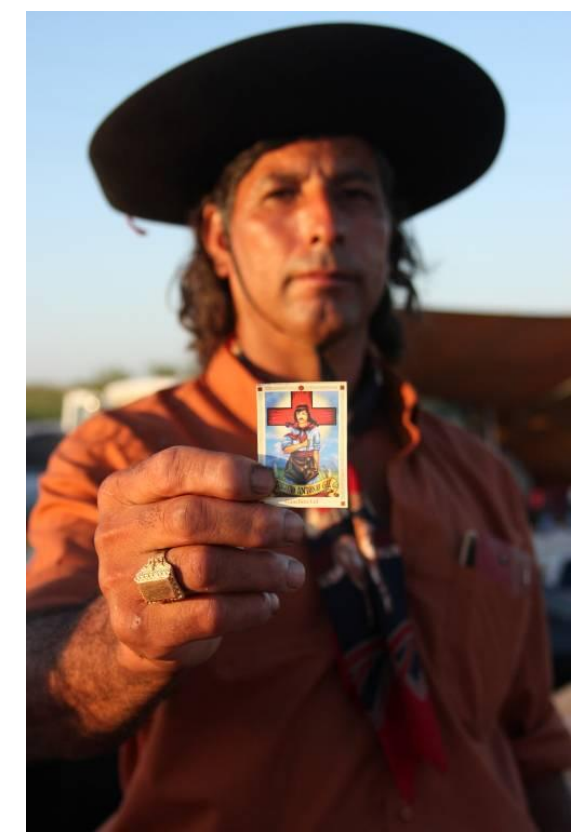

S/T Juan Pablo Faccioli. 2012. Col. Faccioli.

Además cobra relevancia en este proceso de difusión el modo en que ciertas leyendas de la tradición oral son llevadas a los poemas del cancionero popular, y reproducidas en diferentes versiones de chamamé, chacarera, cumbia o rock and roll. Luego estas canciones son difundidas en la radio junto a lecturas de relatos y las narraciones son llevadas a la prensa gráfica, libros, discos y videos de producción propia que circulan en las ferias de las festividades y en Youtube, y también a la TV. Entonces, lejos de extinguirse esa tradición oral sigue viva -aunque reconfigurada por lógica de las industrias culturales- en la escritura, la música y sobre todo en la reproducción de la imagen a través de los medios masivos y las producciones alternativas o populares destinadas al consumo cultural.

En este sentido, la expansión de la devoción del Gaucho Gil que estuvo y sigue anclada en la memoria oral, porque la divulgación de boca en boca y de generación en generación sigue siendo crucial, además cobra potencia en la imagen, su reproducción técnica y apropiación de las industrias culturales y las producciones massmediáticas. Esto demuestra, como señala Martin- Barbero que la industria cultural y la comunicación masiva "son el nombre de los nuevos procesos de producción y circulación de la cultura" (Martin-Barbero, 1999).

Asimismo, el proceso descripto plantea lo que el autor (2002) entiende como "complicidad y complejidad de relaciones entre la cultura oral pre-moderna" (como forma primaria de comunicación) y la "cultura visual moderna" (como especie de "oralidad 
secundaria" - cita de Ong en Martin-Barbero-) $)^{86}$. En esta línea, la reflexión de lo "popular" no puede quedar al margen de la consideración de su dimensión masiva, porque lo popular "no habla únicamente desde las culturas indígenas o las campesinas, sino también desde la trama espesa de los mestizajes y las deformaciones de lo urbano, de lo masivo" (MartinBarbero, 1998: 11).

Desde estas relaciones, las imágenes que refieren al Gaucho Gil, a la vez que se nutren de componentes de la cultura oral con fuerte arraigo cultural -que en su actualización vuelven susceptible de "inferir en aspectos de fe, posicionamientos ideológicos y conductas" (Sánchez Montalbán, 2004: 274)- ; también se transforman en imágenes reproducidas y reproductibles por las industrias culturales puestas a disponibilidad de públicos más amplios para su apropiación y re-significación.

Por ello, Martin-Barbero resalta la importancia de indagar en las matrices históricas, en el imaginario anacrónico, los constructos pasados que resuenan en la trama de cada imagen, porque es este espesor histórico el que tiende a perderse al ser expuesta a las diversas operaciones de traducción, simplificación, discontinuidad y deslocalización que ejerce la mediación tecnológica.

El autor plantea entonces que el desafío está en "no confundir el rostro con la máscara - la memoria popular con el imaginario de masa-" y tener la lucidez de abordar las interdependencias y relaciones que hacen a los mestizajes. En otras palabras, invita a reponer constantemente la pregunta sobre la historicidad densa, el capital simbólico, que sumada a la cualidad visual expresiva y la mediación de las industrias culturales, redobla el poder performativo de las imágenes en la cultura contemporánea.

Cabe señalar que, si bien la fuerza performativa del discurso fotográfico se liga a la potencia de su dimensión de "acto de imagen", que interpela desde la puesta en escena de de sus cualidades materiales como expresivas, su carácter presentativo; la performatividad está aún más asociada a la apropiación socio-histórica y re-iteración de los esquemas iconográficos cargados de valores y convenciones sociales que la re-producción fotográfica en

\footnotetext{
${ }^{86}$ Estas relaciones configuradas por diversas matrices de sentidos construyen el enclave de interpretación que posibilita una aproximación a la dimensión popular-masiva del fenómeno de religiosidad del Gaucho Gil y sus re-presentaciones visuales, incluidas las fotográficas que se analizarán más adelante.
} 
relación a otros textos actualiza, y los modos en que su recirculación cultural influye en la construcción de las memorias y las identidades ${ }^{87}$.

En este sentido, nos preguntamos cuáles son las memorias, las temporalidades en discordia, las representaciones diversas que resuenan en el entramado de la iconografía central del Gaucho Gil -y por contaminación semántica en el mundo visual agigantado del "santo" popular-, en tanto que no sólo logra ganar visibilidad por sobre otras imágenes de la religiosidad sino también reconocimiento y aceptación social.

\section{Símbolos de la formación de la nación en la imagen del "santo" popular}

El antropólogo Alejandro Frigerio señala que el Gauchito Gil "es un símbolo de la argentinidad", un "símbolo que condensa al Martín Fierro y la Cruz" (Saidón, 2011; Frigerio, 2015). Según el autor sería la resonancia de estos arquetipos identitarios en su representación los que edifican el pilar del potencial performativo de su imagen y de la devoción en sí; o al decir de Martin (2008) en los rasgos hipercodificados de la figura popular ${ }^{88}$, entre otros atributos, se asienta su capacidad de ser apropiado, personificado e imitado.

Partiendo del planteo de Frigerio, realizamos aquí una breve historización de la simbología católica y la construcción de la figura del gaucho como representaciones formadoras de identidades/ alteridades políticas nacionales en las que se entroncan algunas tramas de sentido configuradoras de la imagen del Gaucho Gil.

En la Argentina, la religión católica y su simbología funcionaron desde el surgimiento del Estado-nación como núcleos de representación de la argentinidad, destacándose entre las más pregnantes las imágenes de la Cruz de Cristo y de la Virgen María. Si bien, la conformación de la "nación" -entendida como aquella que es construida por los gobiernos estatales- desde sus inicios se valió de la tradición conquistadora española y la acción evangelizadora católica para fomentar una identidad modelada por la espada y la cruz, fue durante el papado de Pio XI que se persigue firmemente el proyecto de encaminar al Estado argentino en la senda de Cristo. Se formaron cuadros disciplinares y militantes para reivindicar a Cristo Rey como el centro y corazón de la vida de la nación (Romero, 1999) ${ }^{89}$.

\footnotetext{
${ }^{87}$ Esta cuestión es retomada en el último capítulo de la tesis en el análisis de algunas imágenes paradigmáticas del corpus.

${ }^{88}$ Esta concepción de Martin es retomada en el apartado siguiente.

89 En este marco y en vías a la celebración del multitudinario XXXII Congreso Eucarístico Internacional realizado en Buenos Aires en 1934, se coloca sobre el Monumento de los Españoles una gran Cruz que no sólo simbolizó aquel acontecimiento y la "obra redentora de Cristo en la tierra", sino también fue el emblema del "alma argentina" y el arma de propagación de la doctrina. Dijo al respecto Pio XII al recordar el congreso: “...en
} 
Por su parte, el fortalecimiento de la figura de la Virgen con la proliferación de advocaciones marianas populares fue central en este proyecto. Cabe recordar que esta representación se estima logró rápida adhesión entre los indígenas que poblaron que suelo argentino en particular y el latinoamericano en general, no sólo debido a la tarea evangelización de la iglesia sino también porque es una imagen que se sobreimprime a la de la "diosa" vinculada a mitos antiguos, a la fecundidad de la tierra, de la que se desprenden deidades femeninas fuertemente entroncadas en las matrices culturales de América Latina, como la pachamama, entre otros (Ameigeiras, 2014: 175)

Desde la reproducción de estos signos se concibe el catolicismo ligado a la identidad nacional y ese lazo se consolida con la instalación del mito de la "nación católica" en la década de 1930 (Zanatta, 1996; Romero, 1999). Este constructo prospera gracias al impulso otorgado por los sectores eclesiásticos aliados al poder político y a las fuerzas armadas en el seno de un país fragmentado por la fuerte ola migratoria.

Hay que recordar que ya hacia el primer centenario argentino se configuraba una masa poblacional que no lograba consensuar símbolos comunes que satisficieran las necesidades de identificación de sectores tan heterogéneos. Entonces, como parte del propósito de "integración" de estos sectores sociales durante buena parte del siglo XX la simbología católica fue propagada "no sólo como una expresión religiosa mayoritaria" sino como una pieza fundamental del proyecto de construcción de una "identidad nacional" (Ameigeiras, 2014: 182).

Respecto al proyecto integracionista, vale señalar que la conformación de una "cultura nacional" se basa en la construcción de otro mito: el del "crisol de razas". Esta concepción hace alusión a "la presunción de que, vía transculturación y aculturación, los diversos grupos culturales en contacto producto de la inmigración terminarían por "fundirse"” (Grimson, 1997: 96). Sin embargo, la integración no fue más que la producción de la argentinidad basada en una clasificación “xenofóbica” de la población (Mármora, 1997); una tipificación que sobrevaloró a los inmigrantes europeos, erigiéndolos como "ciudadanos modelos", mientras se desvalorizó y discriminó a los pueblos indígenas, los mestizos, migrantes internos "cabecitas negras el interior" (principalmente el Nordeste y Noroeste argentino) que se asentaron en los principales centros urbanos industriales a partir de la segunda mitad del siglo XX, así como los inmigrantes latinoamericanos (Giordano, 2004; Grimson, 1997).

nuestra retina parece que no se ha borrado la imagen de aquella Cruz monumental, blanca, poderosa, armónica, como el alma nacional argentina" (Papa Pio XII, Octubre de 1944). 
Volviendo a la época de la configuración de lo que se podría llamar el primer nacionalismo argentino (1870-1930), es posible entender que así como el "crisol de razas" resultó ser una construcción bajo cuyo manto se acentuó un trasfondo de desigualdad, la imposición arbitraria de la simbología religiosa católica también actuó ocluyendo las identificaciones religiosas heterogéneas. La proliferación de esta simbología con pretensiones "unificantes" no solo se dio en paralelo al fomento de los símbolos patrios -la bandera, el himno, la escarapela y la figura de los próceres de la independencia rememoradas a través de monumentos instalados en espacios públicos e instituciones gubernamentales de las principales ciudades y capitales de provincias -, tal como señala Ameigeiras ${ }^{90}$, sino también junto a la re-inserción de la figura del gaucho en el escenario de las disputas por la cohesión social.

La invención del gaucho como símbolo "otro" de la retórica de la nacionalidad remite a la literatura de fines del siglo XIX. Esta figura es identificada primeramente con la barbarie $^{91}$, con el mestizo ${ }^{92}$ reacio a integrarse al proyecto civilizador-que claramente le imponía condiciones de explotación y marginalidad- y que al manifestarse rebelde, hostil y contestatario es perseguido y condenado al exilio o la prisión (El gaucho Martín Fierro, de José Hernández de 1872; Juan Moreira de Eduardo Gutiérrez de 1879). Fue en esa figura del gaucho perseguido y víctima de un sistema opresor en la que los sectores populares encuentran un fuerte signo de identificación ${ }^{93}$. Ante la magnitud de adhesión popular

\footnotetext{
${ }^{90} \mathrm{El}$ autor describe cómo el poder político, la iglesia y las fuerzas armadas reconocieron y fomentaron el valor de los símbolos patrios por su capacidad significativa y movilizadora en torno a determinados ideales. "Así la bandera, el himno, la escarapela junto a la cruz y las imágenes católicas y una vasta iconografía religiosa conformaron recursos clave...", indica Ameigeiras (2014: 183).

${ }^{91}$ Se refiere a la construcción Sarmentiana de Civilización vs Barbarie, en Facundo, de 1845. Allí el gaucho representaba la barbarie por ser vago, mal entretenido y hasta peligroso para la civilización.

92 Esta clasificación nomina desde tiempos de la Colonia la mezcla inter-racial (indígenas con europeos, africanos, etc) con una acentuación despectiva que marca y excluye al no-blanco, al no-puro. Se liga a la categoría de "raza" que actuó como una producción histórica funcional a las condiciones de la colonialidad y a la actual situación post-colonial (Segato, 2007: 100). Sin embargo, Segato ve en ese mestizaje que "se impuso entre nosotros como etnocidio, como cancelamiento de la memoria de lo no-blanco", el camino de la enmienda política, de la inclusión de los expropiados (Segato, 2010: 11- 44). Según la autora, el mestizo es la "raza incierta, incapturable, de realidad multiforme"; o como insiste Hommi Bhabha "un sujeto que habita el borde de una realidad inter-media" que plantea una "inscripción fronteriza" (Bhabha, 2002.30).

${ }^{93} \mathrm{El}$ gaucho Martín Fierro y Juan Moreira no sólo fueron un fenómeno en ventas sino que propiciaron el debate acerca de la legitimidad de los padecimientos y reclamos de los sectores populares ante la clase dominante. La apropiación popular de esta literatura se dio sobre todo a través de la circulación en folletines y revistas, de lecturas en voz alta por parte de lo que Prieto denomina tercer grupo dentro de la clasificación de nuevos lectores (clase media popular argentina que accede a la lectura y escritura pero se opone a la clase culta y de intelectuales en tanto no comparte sus matrices culturales), la memorización y recitación de versos y canciones que permiten la expansión de estas representaciones incluso en la clase popular no letrada (Díaz, 2010; Prieto, 1956). Sobre Martín Fierro un artículo de la revista Panorama de mayo de 1964 señala: "Los críticos, los hombres de las letras, ni siquiera se dan por enterados. Pero el público agota la primera edición en menos de dos meses. En todas partes se leen las aventuras de Fierro: en las estancias, en las pulperías, en los lejanos fortines de la frontera. Alrededor de los pocos que saben leer se congregan multitudes silenciosas que escuchan con unción. Trovadores
} 
alcanzada, esta representación es rápidamente "reciclada" por los intelectuales afines al esquema oligárquico- liberal, aunque las apropiaciones no son lineales y disparan connotaciones diversas.

En este contexto, el gaucho es "re-patriado" y "re-insertado" manso y servil al patrón de estancia y al proyecto moderno de la civilización de fines de siglo XIX y principios del XX (La vuelta del Martín Fierro, del mismo Hernández con otra posición política, de1878; Santos Vega de Rafael Obligado, de 1881, entre otros).

Asimismo, ingresando al siglo XX se resalta del gaucho su carácter "épico y heroico", en reconocimiento a su valor y arrojo en las luchas civiles, y también se le concede la posesión de un lenguaje propio y del saber popular (El Payador, de Leopoldo Lugones, 1944, La historia de la literatura argentina, de Ricardo Rojas, 1969; Eurindia, 1980). De este modo, resulta enaltecido aunque siempre destinado a estar subordinado a la clase dominante (Díaz, 2010).

Con diversos matices otorgados por el lugar de enunciación que asumen los intelectuales, particularmente en vinculación a la desvalorización o revalorización del “componente" indígena en la conformación identitaria del gaucho ${ }^{94}$, esta figura que vuelve a la civilización se torna "legítima" para representar a la argentinidad en tanto pierde sus características de rebeldía, andariego, bravo ${ }^{95}$ y encarna la imagen del buen peón, hombre de familia, de buenas costumbres pero además buen cristiano, patriota y sabio.

Desde esta posición, el gaucho recobra protagonismo en el entretejido ficcional de la nación. Toma forma de símbolo vinculado a la sabiduría, el patriotismo y la religiosidad y sirve como un instrumento "aleccionador" afín al orden dominante. Se constituye como un

ambulantes recorren los caminos relatando las aventuras de Fierro. Y hay quienes, sin saber leer, compran el librito y lo guardan para el caso de de algún ‘leido’ se acerque al rancho” (Germán Pacheco, Panorama, 1964: 42).

94 La configuración del gaucho en Lugones "excluía al indio y al inmigrante, y volvía a conectarse con el tronco español, tan duramente cuestionado desde las guerras de la independencia", era descendiente de los conquistadores. Por el otro, en Rojas, se reafirma su "tronco español y la religiosidad cristiana, explicaba la eliminación del negro, y aceptaba la asimilación, aunque menor, del elemento cobrizo" esto es la raíz indígena (Díaz, 2010: 11). Entrecomillamos la palabra componente para abrir un paréntesis que merece mayor profundización: hay que recalcar aquí el papel de estos intelectuales en articulación con los intereses del poder establecido en la construcción del gaucho como el "otro" que se nutre de "componentes étnicos de la nación" en los que, al decir de Segato, los grupos raciales son transformados, a los fines de ser reducidos y hasta negados. En este sentido, como dice Williams y retoma Segato, el proceso de construcción de la nación oculta "un proceso de construcción de raza" (Williams, 1989 en Segato, 2007: 40).

95 A mediados del siglo XVII y a largo del siglo XVIII, como bien indica Fernando Assunção, los portugueses llamaban a este tipo cultural "gauderio". Designaba a aquel "que vagabundea sin amo ni patrón conocido, trabajando para unos y robando a otros". Luego predominaría el término "gaucho" (Assunção 2007: 27-28). Para referir a esa condición rebelde del gaucho situado al margen de la ley, luego prevaleció en la zona del Nordeste argentino la nominación "gauchillos alzados" y decenas de ellos en Corrientes fueron considerados, tras sus muertes violentas o vistas como "injustas" por parte de la población, como "santos" populares. 
"mecanismo de disciplinamiento no sólo de los sectores populares nativos, sino también de argentinización de los de origen inmigratorio" (Prieto, 1988, en Díaz, 2010), que se difunde a través los aparatos ideológicos del estado: la escuela, la iglesia por un lado y por otro, los medios de comunicación, propiciando procesos de asimilación y reproducción social ${ }^{96}$.

En este sentido, hay que señalar que si bien la imagen del gaucho es una construcción que cobra vida principalmente en la apropiación de su voz en la literatura ${ }^{97}$, éste escapa a una versión estrictamente literaria para convertirse en una pieza clave dentro del sistema de clasificación a partir de la cual se formularon y se pusieron a circular representaciones formadoras de alteridades/identidades políticas nacionales en la Argentina. Es decir, la categoría del gaucho dentro de las clasificaciones sociales configuró en el siglo XX un "argentino tipo", "masculino" y "blanqueado", que junto a la figura del "inmigrante" europeo modelo, conformaron los cuerpos adecuados y dignos de ser legitimados y mostrados, volviendo a "indios" y "negros" una "existencia negada", ocultada (Caggiano, 2012: 80-86).

Vale señalar que la figura del gaucho, lejos de formar parte de un mundo exterior y abstracto, influyó como representación social performativa sobre los comportamientos de los sujetos, contribuyendo a la marcación de pertenencias y distancias identitarias. En otras palabras, la imagen configuró una "representación nodal", en tanto "vehiculiza sentidos políticos fundamentales para la sociabilidad" (Reguillo, 2007: 94), que tuvo y aún tiene fuertes implicancias en la vida social y política argentina porque participan activamente en los procesos de adscripciones identitarias (Cebrelli y Arancibia, 2012).

Llegados a este punto, vale preguntarse entonces ¿en qué medida la imagen del gaucho y la cruz entroncada en la figura del Gaucho Gil revitaliza desde sus diversas instancias de circulación estos debates en torno a la alteridad/identidad nacional? y si como señala Firgerio (2015) ¿es porque la imagen y el imaginario que vehiculiza el Gaucho Gil representa "una gauchesca hecha religión”, y porque nos presenta la "amalgama de Jesucristo y Martín Fierro" que este "santo" popular y las prácticas asociadas a él plantean un inusitado anclaje en y

\footnotetext{
${ }^{96}$ La influencia de la expansión de la enseñanza religiosa católica como aparato de disciplinamiento fue crucial, así como la promoción de un discurso unitario a través de los medios de comunicación masiva. Lida señala que "el catolicismo contó con fuerte presencia en las emisoras de radio más importantes de la época, gracias a Dionisio Napal (orador estrella de Radio Belgrano) y Gustavo Franceschi (en Radio Splendid), entre otras voces (...) a lo que se sumó "el diario "El Pueblo", portavoz de un exacerbado discurso de cruzada que tiñó también con su influencia a la prensa católica de menor envergadura (revistas parroquiales y boletines oficiales en general) (Lida, 2013).

97 Josefina Ludmer acota que la gauchesca representa el doble uso que la nación hace del gaucho: a través de su cuerpo, aprovechado por el ejército patriota principalmente en sus luchas por la independencia, y a través de su registro oral (su voz) utilizado por una cultura letrada en la conformación de una tradición que encarna los más altos ideales de la patria y que además acude al género, en un primer momento, para integrar a los gauchos a la ley civilizada (Ludmer, 1988, en Valle, 2011).
} 
reactivación desde la memoria colectiva?; y de ser así ¿qué versiones de gauchesca y de religión actualiza esta imagen y las prácticas asociadas en medio de las transformaciones socio-culturales y comunicacionales actuales?

Resumidamente, podemos señalar que la imagen y los rituales del Gaucho Gil condensan esas significaciones densas asociadas a los relatos instaurados en torno a "lo gauchesco" y la religión cristiana. Hablamos del gaucho como una figura que ha asumido diversas formas políticas según el contexto y que en los procesos de apropiación popular y masiva contemporánea, a juzgar por las memorias que actualiza la devoción al Gaucho Gil, resalta su carácter rebelde y justiciero; pero también anexa el carácter de "gaucho milagroso" o "milagrero" en vinculación a los rituales de veneración de los difuntos. En esta dimensión cobra relevancia el modo en que las representaciones de "lo gauchesco" y la religión oficial son re-inventadas por los sectores populares en sus prácticas y donde la "religiosidad popular" sincrética también pasa a formar parte de un elemento crucial en las formas de construir identidades en la argentina

\section{El Gauchito entre los difuntos "santificados" massmediáticos de los 90"}

La figura del gaucho como modelo de argentinidad que, en las primeras décadas del siglo $\mathrm{XX}$, se presentaba fuertemente ligada a los símbolos patrios, a una identidad religiosa pretendidamente unitaria y sobreimpresa a una narrativa literaria e histórica oficial, se construyó claramente como respuesta de las clases dominantes a la diferencia y a las contradicciones percibidas como amenaza (Alabarces y Rodriguez, 1997).

En estas condiciones, el símbolo del gaucho se configuró como uno de los núcleos representativos de la conformación del Estado-nación. Esta construcción, entre otras, contribuyó a contar una historia homogénea tanto desde los repertorios lingüísticos como audio-visuales. Sin embargo, una serie de transformaciones socio-políticas y culturales hacia mediados y fines del siglo XX forzarían la develación de los relatos invisibilizados, haciendo evidente las trampas de estas representaciones míticas identitarias.

Luego del auge de las narrativas de ese primer nacionalismo unificante, hacia la década 1940 en adelante se producen algunas des-estabilizaciones en los relatos que hacen emerger en la escena pública nuevas demandas de representación por parte de las "minorías" o los sectores marginalizados. Por ejemplo, en el campo religioso, fueron muchas las voces

que cuestionaron el mito de la "nación católica" y varios estudios coinciden en que si bien los cambios exógenos a la institución católica tuvieron amplias repercusiones y derivas, 
particularmente los golpes endógenos resultaron decisivos ${ }^{98}$. Parker (2014) describe el debilitamiento institucional católico latinoamericano como un "frente interno", en cuyo marco del caso argentino vale mencionar hacia la década del cuarenta el desarrollo de movimientos católicos juveniles que pusieron en jaque "la rigidez y solemnidad de las jerarquías eclesiásticas" (Lida, 2013). Este activismo instala, aunque por momentos de forma solapada, el debate obligado sobre la necesidad de la "modernización" y aggiornamiento de la iglesia conservadora.

Hacia mediados de la década del cincuenta, el enfrentamiento de la institución católica con el gobierno de Juan Perón hace que resulte más difícil defender la concepción de la “nación integralmente católica" (Lida, 2013). Si bien, estos acontecimientos, así como nuevas producciones en el ámbito de los medios masivos que empezaron a atender demandas de representación de los sectores populares, fueron generando las condiciones de posibilidad para visibilidad de los relatos ocultados, durante los años setenta con la instauración del régimen militar se habla de un renacimiento del catolicismo y un retorno de la alianza IglesiaFuerzas Armadas Argentinas-Estado de los años treinta.

Un nueva reconfiguración de representaciones fue posible en el país con el advenimiento de la democracia en 1983, en cuyo escenario la diversificación religiosa y cultural se ensancha. Desde los márgenes asumen importante visibilidad pública movimientos evangélicos, especialmente pentecostales; así como los grupos que nuclean a adventistas, testigos de Jehová y mormones. Asimismo, toman notoriedad manifestaciones vinculadas a espiritualidades sincréticas con influencias afroamericanas, indígenas e incluso cristianas pero que ya no responden al mandato eclesial de forma excluyente.

Este proceso de visibilización expandida de la diversidad religiosa se ve influenciado por transformaciones socioculturales, económicas y políticas pero también reconfiguraciones comunicacionales. Particularmente, hacia la década de 1990 se incrementa la producción massmediática interesada en explotar una serie de condimentos noticiables que presentan los cultos populares: la espontaneidad y alta expresividad corporal, teatral, hasta melodramática de los fieles en interacción con la divinidad, así como del carácter multitudinario y espectacular de las manifestaciones (Barrios, 2014).

98 En términos generales se pueden citar como transformaciones exógenas fuertemente imbricadas a las endógenas: el debilitamiento del estado nación y la dispersión de sus aparatos de disciplinamiento y control, así como el quiebre de la alianza de este estado con la iglesia frente a la emergencia y la necesidad de respeto a la interculturalidad y a la diversidad de credos en un contexto consolidación democrática iniciado en los ochenta; se suman el crecimiento de una cultura del consumo y la difusión de valores contradictorios con la cultura católica tradicional en el marco la economía capitalista globalizada; el crecimiento y la diversificación de los medios masivos de comunicación insertos en una economía de mercado, así como la pluralización de las ofertas educativas (Ameigeiras, 2014; Parker, 2014). 
En este marco, la figura del Gaucho Gil re-aparece -más allá de las prácticas rituales rurales familiares- en movilizaciones devocionales multitudinarias que ganan las portadas de diarios y las pantallas de televisión junto a la notoriedad de otras manifestaciones devocionales vinculadas a antiguos y nuevos difuntos dotados de poderes diversos y que son los llamados "santos populares"99: sobresalen la Difunta Correa de San Juan, con consolidada popularidad en la época, y los nuevos fenómenos de "canonización" de los cantantes de música popular Gilda y Rodrigo, tras sus muertes accidentales.

Estas manifestaciones con gran adhesión popular no sólo vienen a contradecir los “pronósticos apocalípticos acerca de la 'desaparición' o 'decadencia' de la religión” sino que llevan a confirmar su "vigencia" y "renovada vitalidad" (Amegeiras, 2008: 10); y también a instalar la pregunta sobre los factores y caracteres o matrices en tensión que modelan esta vitalidad.

Al respecto, varios estudiosos de la religión aducen que los cultos en torno a estas figuras se constituyeron en un "refugio" de las clases populares frente a la desprotección del Estado, la fragmentación y dispersión de programas sociales, el crecimiento de la pobreza, el desempleo; en definitiva la profunda crisis social, política y económica que hizo eclosión en diciembre de 2001 y que, entre otras cuestiones, propició replanteos en torno los modos de construir identidades. En cambio, otros investigadores insisten en apuntar que si bien este escenario evidenció la ruptura de los grandes relatos identitarios, acentuando la visibilidad de otras prácticas y retóricas de religiosidad, muchas de estas devociones plantean un fuerte arraigo social y una historicidad más extensa y densa que excede la coyuntura de la crisis ${ }^{100}$.

La importante difusión de los casos de Gilda y Rodrigo, hace emerger conjeturas en torno a la existencia de una "nueva ola de canonizaciones" de los años noventa en la Argentina. Sin embargo, Carozzi (2006) relativiza esa hipótesis para resaltar la influencia de los medios masivos de comunicación en la visibilidad expandida de estas devociones. La autora indica que en los noventa lo que sucede es la actualización de la re-memoración de antiguos difuntos (como el caso de los gauchillos rebeldes, entre ellos Antonio Gil o el caso

\footnotetext{
${ }^{99}$ Los difuntos "milagrosos" son la mayoría de los llamados "santos populares". Es decir, son aquellas personas que han sido sometidas a procesos de canonización por parte de los pueblos, como instancia diferenciada de los procesos canonización oficial, luego de haber sido víctimas de injusticias o sufrir una muerte violenta. Por un lado, estas sacralizaciones populares son leídas como marginales y hasta cuestionadas por la institución católica, y por otro, son entendidas como espacios de "revancha simbólica" o formas alternativas de veneración recreadas por los sectores populares (Ameigeiras, 2008: 70 -71).

100 Según Eloisa Martin "la crisis que estalla a fines de 2001 aparece más como motivo de ruego a los santos que como una variable que incida en algún tipo de crecimiento en la devoción”. Insiste en que la crisis como otras catástrofes "no implica cambios ni aumentos en las prácticas de religiosidad per se: al contrario, permite ver que estas persisten en el tiempo, adaptándose a los motivos del momento histórico" (Martin, 2007: 72).
} 
de la Difunta Correa) con la incorporación de rituales en torno a nuevos difuntos (como el caso de los cantantes Gilda y Rodrigo fallecidos en 1996 y 2000 respectivamente).

En este sentido, Carozzi señala que la tradición de veneración de los difuntos no es nueva, sino que en algunos casos esas prácticas estaban veladas o con una difusión circunscripta a un espacio geográfico reducido, ya sea local o regional (como el caso de otros gauchillos alzados que son considerados milagrosos en sus localidades ${ }^{101}$ sin trascendencia nacional); mientras que las manifestaciones más recientes se presentan como "continuidades" de aquellas prácticas devocionales ancestrales.

"Más que una ola de nuevas canonizaciones, en la década de 1990 se presencia una ola amplia de difusión mediática de algunos nuevos difuntos que hacen milagros”, insiste Carozzi. Asimismo, pone en duda que en los casos de los cantantes "santificados" esa difusión se asiente principalmente en los "milagros" fundamentados en la muerte violenta de los artistas, siguiendo la concepción eclesiástica. La autora conjetura: "El milagro aparece en las pantallas de televisión y en las páginas de los periódicos en razón de que los difuntos que los realizan se han vuelto famosos por otras razones" (Carozzi, 2006: 98).

Ahora bien, suponiendo que la "popularidad" de estos nuevos difuntos se incrementa por su extrema difusión mediática a condición de que son personajes que ya gozaban de fama en vida, como una de las motivaciones posibles, cabe preguntarse ¿Cuáles son los otros factores que hacen a la extraordinariedad y "popularidad" de estas figuras milagrosas?; y particularmente en relación a los antiguos difuntos, teniendo en cuenta que los gauchos rebeldes milagrosos son venerados en distintos puntos del país desde el siglo XIX ¿qué hace que desde la provincia de Corrientes la figura del Gaucho Gil sobresalga mientras otros son relegados? ¿Qué elementos influyeron para que el Gaucho Gil se transforme en una figura “popular” y massmediática en los años 90’ y más acá?.

Hay que recordar, que en el caso de Gil los especialistas señalan que su "popularidad" 102 incluso ha superado en los años 2000 a la Difunta Correa, cuya fama también había

\footnotetext{
${ }^{101}$ Con prácticas de rememoración en distintos puntos del país, son conocidos: el gaucho Lega Olegario Gómez, Francisco José, Isidro Velázquez, Juan Bautista Bairoletto, Juan Francisco Cubillos, Andrés Bazán Frías, Aparicio Altamirano, José Dolores Córdoba, Mariano Córdoba, entre otros (Coluccio, 1995; Chumbita, 1995, entre otros). Solo en la provincia de Corrientes se puede rastrear la leyenda viva de al menos 60 gauchillos alzados, aunque sólo algunos como figuras milagrosas (Piñeyro, 2005).

${ }^{102}$ Aquí la palabra popularidad está asociada a su difusión y apropiación masiva más que a la reflexión teórica que liga lo popular al sujeto "pueblo" o la articulación de sectores sociales en conflicto, conceptualización que se indaga en otros apartados. Por otra parte, vale señalar la relación de la "popularidad" en términos de adhesión social que, en lo que hace a encuestas sobre identificaciones religiosas, la figura del Gaucho Gil ocupa un papel importante en la Primera Encuesta sobre Creencias y Actitudes Religiosas en Argentina realizada por el CEIL en 2008. Según el relevamiento en el Nordeste un 57.6\% de la población manifiesta su creencia en este "santo" con una tendencia ascendente en distintas regiones del país.
} 
trascendido las fronteras de su provincia de origen de modo similar al caso de gaucho correntino, sumando adeptos y capillitas a lo largo de las rutas de diferentes regiones del país ${ }^{103}$.

La reflexión de Carozzi también convoca a pensar la extraordinariedad de estas figuras descentrando los estudios de la religiosidad popular del paradigma eclesiástico. Dicho esquema, según interpreta la autora siguiendo a Eloisa Martin, restringe el fundamento de las "canonizaciones" al hecho de que los milagros son posibles por la muerte violenta que sufrieron estos difuntos, sin considerar otras motivaciones que movilizan al pueblo en torno a estos símbolos ${ }^{104}$ y sin considerar también que los milagros para la cosmogonía popular no son algo extraordinario sino que forman parte de lo cotidiano.

Martin (2008) particularmente esboza varios factores que hacen que estos "seres" se destaquen y actúen de forma diferenciada y poderosa en el mundo. Dice que la "muerte trágica" es uno de los "eventos que puede inscribir a una persona en una textura de extraordinariedad" pero no la única. Entre otros atributos, la autora resalta el carisma y la autenticidad. El carisma es entendido "como la humanidad de alguien que, por sus características, podría elegir la distancia de quienes lo admiran, pero mantiene una performance de horizontalidad: su extraordinariedad se basa en ser alguien común" (Martin, 2008); mientras que ser auténtico implica mostrarse tal cual es, sincero, aunque la personalidad conlleve valores a veces contrapuestos.

En relación a estas características, es recurrente escuchar a los devotos y simpatizantes del Gaucho Gil resaltar como positivo su imperfección mundana, su vinculación con los buenos actos y paralelamente con los errores que propicia mayor identificación en los fieles. Los consultados señalan: “era un hombre común, como nosotros”.

Los imaginarios circulantes construyen al Gaucho Gil como un personaje por naturaleza antagónico. Como héroe, que robaba a los ricos para dar a los pobres, estableciendo un nuevo sistema de reparto de la riqueza, entre otras cualidades; y por el otro

\footnotetext{
${ }^{103}$ La leyenda de la Difunta Correa (Deolinda Correa) también se remonta a la época de enfrentamiento entre unitarios y federales. Señalan que su padre y su marido eran perseguidos por la policía. Dicen que partió con su niño tras su joven esposo que había sido reclutado por las fuerzas montoneras y otros que huyó de los acosos del comisario del pueblo que la pretendía. En camino, muere de sed y la encuentran entre los cerros con su hijo en brazos y amamantándose. La escena es interpretada como una historia de martirio, de amor materno y conyugal; mientras la supervivencia de su niño es señalada como "un milagro". A partir de allí, se le rinde culto a través de prácticas que encuentran muchas similitudes con los rituales en torno a Antonio Gil.

104 A esta reflexión también remite la enunciación del término santo entre comillas en esta tesis, ya que la denominación podría interpretarse en términos de la nominación y designación jerárquica-institucional eclesiástica; aunque historizaciones como las de Rubén Dri, advierten insistentemente que los primeros santos no eran canonizados por la jerarquía sino por el pueblo y desde las prácticas vinculadas a los difuntos se recupera esa tradición desmarcada de la institución.
} 
como antihéroe por sus prácticas delictivas. Este antagonismo parecería formar parte de las características de ese "ser extraordinario" como describe Martin a los santos populares, en tanto que preceden toda moral participando de una "textura diferente del mundo que es previa a la concepción cristiana que considera lo sagrado como lo infinitamente bueno, en contraposición a lo profano, el lugar del mal” (Martin, 2008).

Por otra parte, Martin observa en los rasgos hipercodificados de las representaciones iconográficas de estas figuras su potencial para ser apropiados, personificados e imitados; agencia que plantea como central en la configuración de extraordinariedad y "popularidad". $\mathrm{Al}$ respecto, la socióloga agrega que para que estos seres se destaquen de su contexto social, étnico y estético de origen, se requiere de los sujetos que reducen la representación visual de estas figuras a "un número reconocible de cualidades" (Martin, 2008).

Así, los devotos del Gaucho Gil, valiéndose de las referencias de los relatos orales crearon la iconografía de este "santo" popular desde la sobreimpresión de símbolos muy codificados y anclados en la memoria colectiva a partir de imágenes pregnantes (el gaucho y la Cruz $)^{105}$. Luego, los promeseros y simpatizantes re-crearon esa imagen a través de diferentes prácticas de apropiación, formas de inscripción e incorporación territorial o corporal.

En definitiva, los procesos de re-apropiación simbólica no sólo definen la extraordinariedad y popularidad del "santo" sino que sobre todo confirman que las formas hipercodificadas que configuran su iconografía, a su vez ligadas a prácticas de exhibición ritualizadas, son cruciales en su proliferación. Se trata de aspectos que diferencian al Gaucho Gil de los otros gauchillos alzados también considerados santos populares

También por estas características, la iconografía central del Gaucho Gil se abre a rearticulaciones diversas que propician los sujetos desde sus diversas posiciones respondiendo a necesidades y demandas sociales diferenciadas en contextos también diversos.

\section{Una imagen y múltiples identidades en un campo religioso y comunicacional diversificado}

Hacia la década de 1990 y los años 2000, la visibilidad de las prácticas devocionales ligadas al Gaucho Gil y las múltiples apropiaciones que de su imagen central se realizan no responden sólo al impulso del discurso mediático tradicional (prensa, radio, tv) que da lugar a

105 Esta operación remite al funcionamiento de los tiempos largos de la memoria en la construcción de representaciones al que refieren Cebrelli y Arancibia (2005). 
estas historias, a pesar de las retóricas aún muy marcadas por el tono despectivo en parte heredada del discurso eclesiástico, sino también a las formas alternativas de comunicación que los propios devotos y simpatizantes del "santo" popular construyen.

En el marco de otra formación histórica ${ }^{106}$, a través de nuevas formas y estrategias de comunicación directa y mediada las personas vinculadas a estas prácticas hacen visible su realidad y pensamiento desde otras miradas que ayudan a actualizar, reforzar y/o se diferenciarse parcial o radicalmente de las visiones que sobre ellos circulan a través de los discursos dominantes.

En el fenómeno del Gaucho Gil cobra relevancia la producción y re-distribución de relatos de los promeseros y promotores de la devoción a través de folletines, afiches y retratos de edición propia; la construcción y edición de blogs, páginas web; música y videos en reproducidos en cds, dvds; la inscripción de tatuajes en la piel; impresión de remeras, camisas, pañuelos, estampitas, cintas, banderas, banderines y accesorios diversos.

Este complejo mundo cultural-comunicacional se desarrolla con fuerza desde los santuarios del Gaucho Gil, especialmente el situado a la vera de la ruta 123 en Mercedes y otros altares que proliferan a la vera de los caminos del país, y aquellos instalados domicilios particulares; así como en los santuarios virtuales también construidos por los devotos donde se privilegia el intercambio de fotografías auto-referenciales, imágenes animadas, videos, intenciones, oraciones, recuerdos, comentarios, testimonios y foros con opiniones discrepantes.

Aquí las imágenes reproducidas en estampas y otros medios plantean el rol central relacional de la iconografía en dos direcciones: la primera tiene incidencia la configuración de la relación de los promeseros con el "santo", ya que muchas de estas imágenes son apropiadas en el seno de los rituales para agradar a la divinidad y estrechar vínculos con ella; y la segunda influye en la forma que encuentran los devotos de representarse, dar una imagen de sí para el afuera; así como para construir "emblemas de comunidad".

En este sentido, es interesante ver el rol que la figura popular comienza a ocupar entre los años 90 y los 2000 entre los sectores sociales más postergados. La imagen empieza a erigirse desde la zona rural, desde los barrios marginales del conurbano bonaerense y las villas como el símbolo aglutinador de diversas actividades socio-culturales y económicoproductivas tendientes reconstituir lazos sociales y a sobrellevar la crisis. Varios barrios

${ }^{106}$ Esta formación se ubica luego del regreso de la democracia signada por la globalización de la cultura y la comunicación, el avance de las nuevas tecnologías, a la vez por una política neoliberal de los 90 que deriva en una situación de crisis socio-política y económica desde la cual empiezan a pensarse diversas estrategia para salir de la crisis, reconstituir los lazos sociales y redefinir las identidades. 
empiezan a ser nombrados Gauchito Gil, también grupos musicales, grupos de murgas, clubes o asociaciones, incluso comercios.

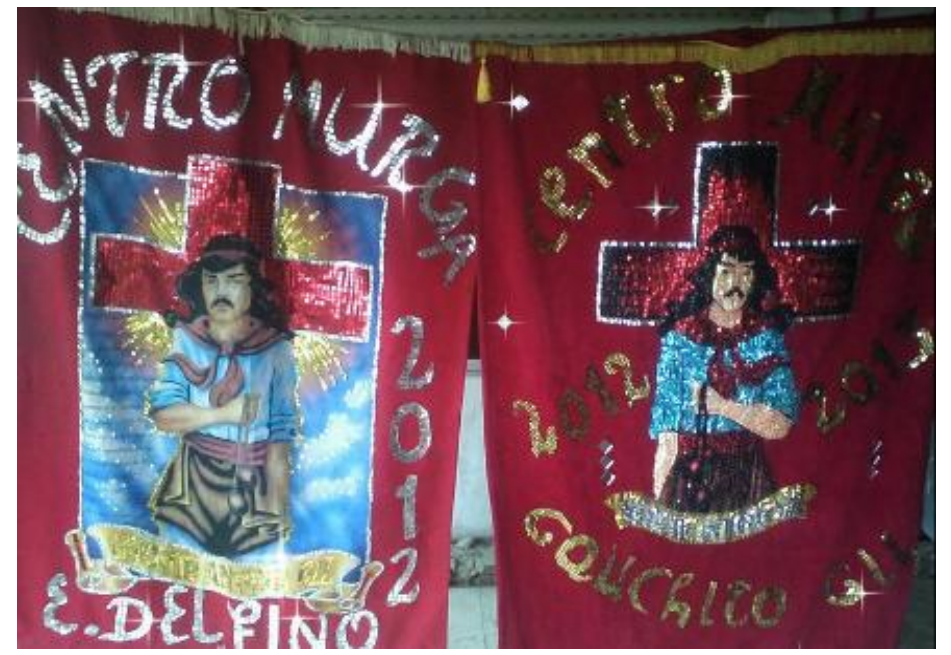

Foto del Centro Murga Gauchito A. Gil. S/T, Col. Murga ${ }^{107}$ Para esta agrupación, la figura del Gauchito Gil se plantea como signo aglutinador y distintivo no sólo de la comunidad murgueros, sino también de los devotos que entremezclan palabras de aliento a la actividad de la Murga con peticiones y agradecimientos al "santo" popular en los comentarios de la fotografía que circula en la web

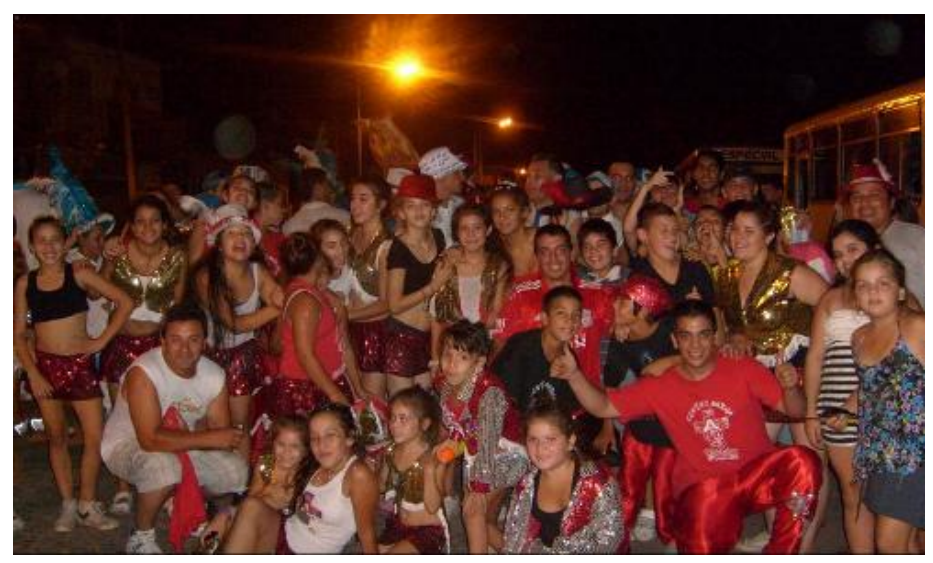

Foto Centro Murga Gauchito Gil. S/T. Col. Murga El color rojo y la iconografía central de la devoción al Gaucho Gil se reproducen en la vestimenta de los murgueros. La agrupación es oriunda del partido de Tigre, en la provincia de Buenos Aires. Algunas presentaciones fueron grabadas en video por ellos mismos y están disponibles en un canal de Youtube.

El acceso a las nuevas tecnologías de la comunicación y la información por parte de los sectores populares, evidencia cómo los grupos de promeseros y/o comerciantes vinculados a la manifestación que antes eran solo objetos del enjuiciamiento de los medios tradicionales, ahora plantean una participación activa en la construcción de su representación, generando

${ }^{107}$ Disponible en el perfil público de Facebook: https://www.facebook.com/MurgaGauchitoGil 
visibilidad de grupo y visiones que incluso inciden en el reforzamiento o re-configuración de las valoraciones dominantes ${ }^{108}$. Las repercusiones más evidentes se dan en el discurso eclesiástico y el mediático a partir de la década del noventa. El primero que antes demonizaba a las prácticas de religiosidad ligadas a Antonio Gil por considerarlas "paganas" y asociadas a una práctica "desviada" de los verdaderos valores cristianos, en el ingreso del siglo XXI por la expansión de la devoción a través de los medios y las industrias culturales, propicia el involucramiento de la Iglesia con el fenómeno desde acciones en el santuario mercedeño con el fin de "reencauzar" la relación con esa masa cada vez más creciente de fieles y seguidores que moviliza el Gauchito ${ }^{109}$.

El discurso mediático viró en parte en el mismo sentido y sobre todo lo hizo para servirse de los elementos expresivos y emotivos de los rituales y alimentar la "cultura de la conmoción" y "el imaginario del desborde y el exceso que termina reeditando la producción de la diferencia" (Reguillo, 2008: 9). Sin embargo, como indica Caggiano, estas posturas sólo son comprensibles dentro del "complejo juego de límites y presiones del proceso hegemónico" (Caggiano, 2012: 270) que requieren un abordaje mayor y se retoma en capítulos siguientes.

Cabe aclarar que la observación de la producción creativa de representaciones por parte de los sectores populares no pretende alimentar una mirada idealizada y acrítica. Por el contrario, la descripción busca resaltar la participación activa de los sectores populares en este ámbito complejo de producción cultural sin dejar de indicar que existen múltiples problemas vinculados a las garantías de derechos de acceso, formación, e igualdad en las condiciones de producción, distribución y consumo que condicionan la configuración de una autorepresentación más democratizadora.

Asimismo, cuando hablamos de relatos dominantes en el caso del Gaucho Gil, no referimos sólo a los discursos y retóricas de la llamada "cultura nacional" sino también entran en tensión los discursos que responden a los esquemas de dominación trasnacional vinculados a la expansión del modelo económico político neoliberal que desde los años noventa impactó en las prácticas socio-culturales cotidianas argentinas, los discursos mediáticos y las experiencias y prácticas de los sectores populares (Grimson, 2007).

\footnotetext{
108 En este sentido, Reguillo explica que la introducción de otras voces y miradas "no anula el conflicto ni representa la abolición de la visión dominante, pero coloca la disputa (por la representación legítima) en otro plano de resolución al introducir, en un espacio público expandido, contrapesos a la voz monocorde de la dominación” (Reguillo, 2008: 4).

109 Ver más Capítulo 4.
} 
En este sentido, desde la aproximación al intercambio de formas simbólicas en el seno de la festividad central del Gaucho Gil en Mercedes y otras representaciones que las refieren y re-significan (observaciones en campo en la festividad, aproximaciones a discursividades circulantes en la web y análisis de fotografías que forman parte del corpus de investigación, algunas de ellas incorporadas en este capítulo), observamos cómo las matrices de identificación vinculadas a valores comunitarios pre-modernos, si bien perviven, pierden fuerza frente a la sobreexposición de las formas de la "identidad nacional". Asimismo, mientras los nodos representacionales de "la nación" siguen planteándose como estructurantes de los modos de ser, de mostrar(se) y actuar entre los devotos y participantes en general de la cosmogonía del Gaucho Gil; también esas matrices se mixturan con formas modeladas por el mercado y el consumo trasnacional.

En esta línea de lectura, las representaciones circulantes muestran cómo las tradiciones de la veneración de los difuntos y de la imagen del "curuzú" (cruz) guaraní perviven como núcleo de identificación de las comunidades con fuerte anclaje en las prácticas rituales de rememoración. Mientras, las mismas se intersecan, entran en tensión con la presencia de símbolos asociados a valores políticos partidarios nacionales y provinciales (pañuelos y cintas rojas y coloradas refiriendo a unitarios y federales / liberales y autonomistas) y el signo pregnante de la Cruz católica (como representación de la "nación católica").

Así también, las representaciones del Gaucho Gil se entroncan a la figura del gaucho de la "nación masculina-blanca-pampeana" (una imagen idealizada difundida por la literatura, el cine nacional desde su época de oro -mediados del s. XX-, la escuela, los medios, los archivos, etc), pero también del gaucho correntino (que nombra en la provincia un símbolo del valor, del trabajo agrario, del coraje de los hombres que lucharon en las batallas de la independencia, pero también refiere a la organización social patriarcal y conservadora local, donde las posiciones de liderazgo principalmente están a cargo de los hombres; ellos llevan la cruz, portan los estandartes distintivos y encabezan los desfiles y procesiones). Esto muestra lo que señala Caggiano (2012), cómo los repertorios visuales hegemónicos postulan legitimidades y consagran jerarquías, posiciones y relaciones sociales. 


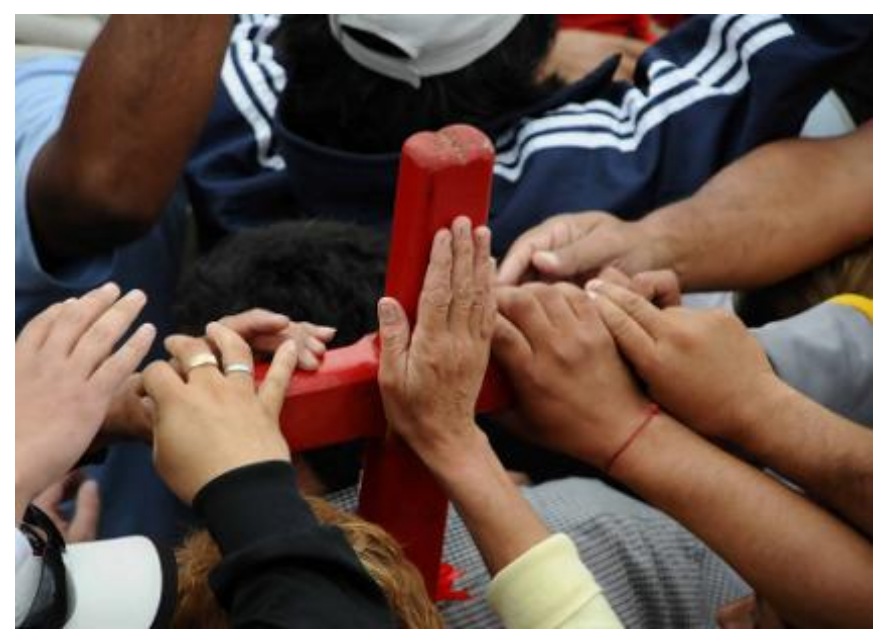

Juan Pablo Faccioli. S/T, Mercedes, 2009. Publicada en Agencia Corrientes, 9/1/2009; otros: Urgente 24,

Nuestra Mirada, Flickr del fotógrafo. La Cruz peregrina, simboliza el Curuzú Gil, aquel madero que fuera plantado por el verdugo de Antonio Gil en el lugar donde el gaucho perdió la vida. La Cruz es venerada los 8 de enero en Mercedes y es el signo central de toda una serie de ritos que se despliegan en la fecha conmemorativa.

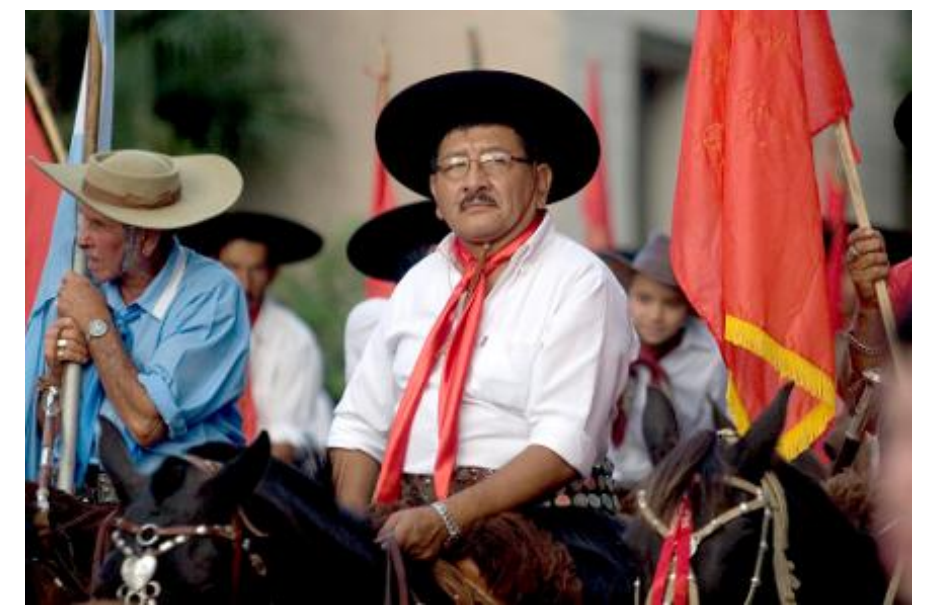

Foto Guillermo Rusconi. S/T, Mercedes 2011. Publicada en el Flickr del fotógrafo. Los Gauchos de Antonio Gil: sus indumentarias están signadas por los colores celeste y colorado que identifican a los partidos políticos Liberal y Autonomista en Corrientes. Asimismo, ellos presiden las ceremonias centrales, se presentan como la proyección del Gaucho Gil y por añadidura la agrupación se hace cargo la custodia de su cruz y su memoria.

Por otra parte, la imagen del gaucho nacional crucificado y de mayor circulación se resemantiza junto a los objetos, accesorios dispuestos para la compra-venta en las ferias de las festividades. Allí las artesanías o los recuerdos de producción local con improntas de una iconografía regional se mezclan y en algunos estantes hasta son sustituidas por imitaciones importadas más baratas, simplificadas y serializadas.

La iconografía central y los rituales en sí cobran nuevos sentidos en relación con la circulación productos de consumo: las tallas artesanales se entrelazan con las figuras en yeso; los stickers para autos, camiones u otras propiedades, como los tatuajes con la imagen del 
santo presentan re-versiones ilimitadas; incluso los rasgos del "“santo" popular" que aparecen en las imágenes animadas de la web e imitan al gaucho Martin Fierro se "contaminan" con aquellas que replican facciones de personajes de la cultura pop coreana o la cultura pop estadounidense.

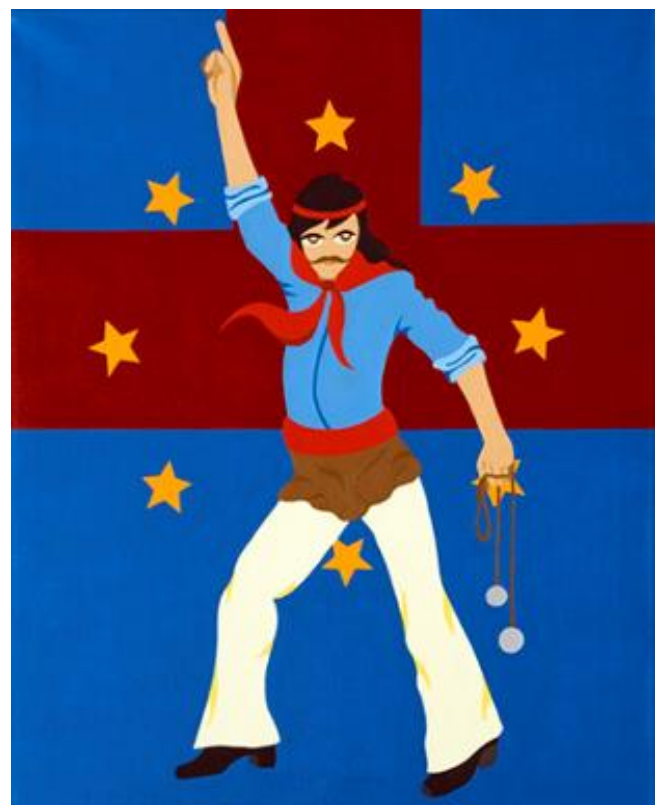

Autor Desconocido. S/T. Circulación en la Web. Esta imagen apareció en un video de Youtube del tema "Antonio Gil" del cantante de cumbia Antonio Rios. Se trata de una re-creación del gaucho con la pose de baile de John Travolta en Fiebre de sábado por la noche.

En este escenario que se debate entre la homogeneización y la heterogeneización de los procesos socio-políticos, económicos y culturales y que se traduce en un mundo culturalvisual multiforme del Gaucho Gil, se desarrollan las nuevas formas de comunicación entre devotos, comerciantes, instituciones, productores audio-visuales, entre otros. Asimismo, estos intercambios ponen de manifiesto el desplazamiento de íconos-muchas veces desimbolizados, reducidos en densidad histórica y cultural por el proceso de simplificación al que son sometidos- a través de los cuerpos, los medios masivos electrónicos, así como de las territorialidades que son permanentemente re-configuradas en la interacción, respondiendo a lo que Appadurai (2001) llama nuevas formas de configuración de la "imaginación de la vida social". Es decir, una imaginación construida a través de "paisajes" étnicos, mediáticos, tecnológicos, financieros e ideológicos en interacción y en constante movimiento (Appadurai, 2001). Un contexto que, a su vez, pone en crisis la idea de "nación" de Anderson (1993), entendida como "comunidad política imaginada" que demarca su lugar a partir de una serie constructos identitarios unificantes. 
El flujo de los mensajes a través de la red global y las diversas reproducciones y apropiaciones de las imágenes que realizan los grupos sociales en su contacto intra e intercultural también permiten explorar las múltiples ideas de "nación" que se construyen "desde abajo". Es decir, que construyen aquellos sujetos que "no gozan del aparato estatal" para legitimar su imaginario y que "no presentan las estructuras retóricas de los grandes relatos estatalistas y nacionalistas" (Grimson, 1997: 97).

Particularmente, Grimson habla de la construcción de la nación "desde abajo" en su análisis de los relatos de la diferencia y la desigualdad de los inmigrantes bolivianos en Buenos Aires. Resulta productivo comprender los planteos, las representaciones y las apropiaciones que empezaron a construir y movilizar los migrantes correntinos instalados en el Gran Buenos Aires y otras regiones del país hacia mediados (1940-1970) y fines del siglo XX (1990-200). Ellos, a partir de la figura del Gaucho Gil, construyeron un código común y un sentido de colectividad más allá del anclaje territorial de origen.

Los festejos centrales del 8 de enero en los altares y santuarios de todo el país, que albergan prácticas de matrices heterogéneas, también presentan ritos y lenguajes que actualizan alguna "tradición" correntina, como por ejemplo la música, la danza chamamecera, la vestimenta de campo en alusión a la vida, las costumbres y valores del gaucho correntino. Además, en estas fiestas y ferias, también los grupos de devotos testimonian su creencia a través de prácticas de inscripción corporal (como los tatuajes) y de in-corporación (gestos, movimientos del cuerpo, prácticas interacción personal) que posibilitan la re-memorización y re-producción de códigos culturales y discursos vinculados con el arraigo y el desarraigo.

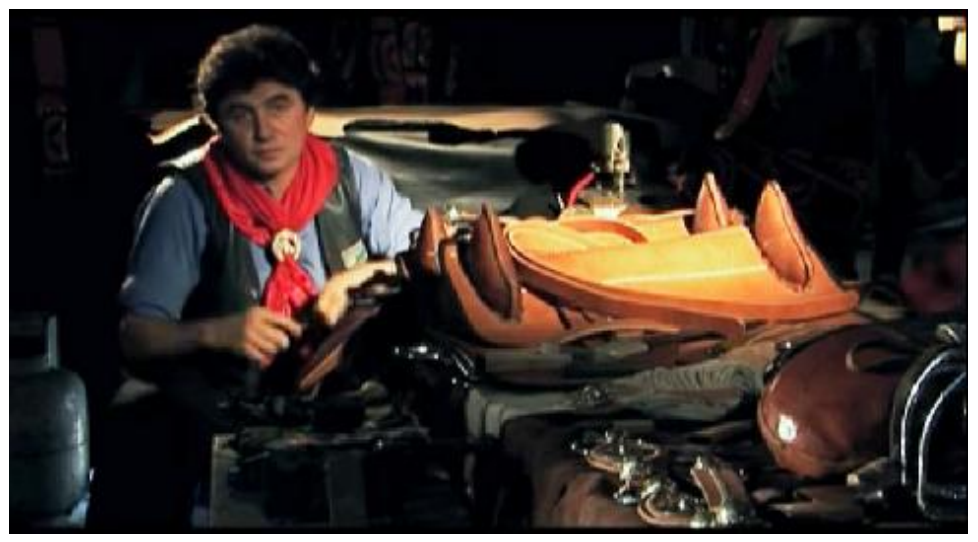

Fotograma del Film "El último refugio" (2011), dirigido Pablo Valente, disponible en Youtube. Uno de los testimonios que reproduce el documental es de Pedro, quien llegó a Buenos Aires en busca de trabajo y además de testimoniar su devoción por el Gauchito da cuenta de su oficio artesanal ligado a la producción de indumentaria gaucha y la actualización de la cosmogonía de vida de correntino fuera de Corrientes. 


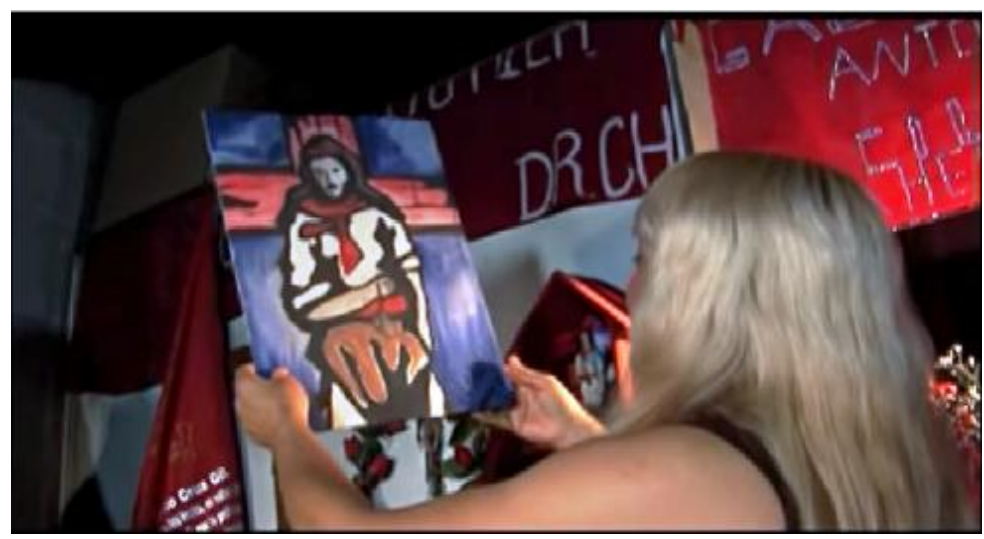

Fotograma del Film "El último refugio" (2011), dirigido Pablo Valente. También habla Estela, quien heredó de su padre el santuario del Gaucho en la provincia de Buenos Aires y allí continuó con la tradición familiar de veneración y de propagación de los milagros del santo por diversos medios, como la radio donde conduce un programa con contenidos de chamamé, leyendas y costumbres correntinas.

De este modo, la figura de Gil nuclea una serie de "elementos diacríticos de la correntinidad" (Guber y Soprano, en Martin, 2002) como también sucede como la imagen de la Virgen de Itatí, otro "símbolo de la correntinidad" (Martin, 2002) que es utilizada por los correntinos en contexto migratorio para marcar pertenencia ${ }^{110}$.

Por otro lado, la imagen de Antonio Gil, que vehiculiza la historia de un gaucho, rebelde y justiciero social, proyecta formas de identificación social teñidos de diversos matices de sentido, configurándose principalmente como una bandera de las poblaciones marginales como hemos visto en el ejemplo del Centro Murga Gauchito Gil, entre otros.

Recordando que Antonio Gil "robaba a los ricos para dar a los pobres", que era "perseguido por la policía" y vivía al "margen de la ley"; o simplemente porque "es un santito poderoso al que le podés pedir lo que necesites", los sectores sociales más desplazados acuden a él por trabajo, sanación, protección o liberación. Sin embargo, se puede ver que los sectores con mejor posición social también le piden por salud, dinero, éxito, fama, prosperidad; mientras otros más allá de los fines religiosos se acercan a su figura y la toman como inspiración para producciones artísticas, diseños de moda o marcas publicitarias.

La última matriz de sentido, que excede la relación de la imagen ligada a la idea de la demarcación de "una identidad religiosa" o de "una cultura provincial" para configurar la representación de una argentinidad popular-masiva heterogeneizada; a su vez, plantea la necesaria revisión de los complejos sentidos de las representaciones de la "nación"

110 Los elementos diacríticos refieren a elementos culturales diferenciadores. Martin recalca que estos marcadores "dejan de desempeñar el papel original al que estaban destinados y van convertirse en emblemas del grupo. La Virgen de Itatí, en este caso, en cuanto "es Corrientes" y "es un signo de la cultura correntina" es englobante: su influencia excede a los católicos e independientemente de su significado religioso, vale en cuanto símbolo de la correntinidad”. (Martin, 2002). 
integracionista (el gaucho Martín Fierro y la Cruz) que las prácticas devocionales y las imágenes del Gaucho Gil movilizan y resignifican. Más aún en un escenario de transformación histórica, religiosa, cultural y comunicacional en el que las identidades colectivas entran en crisis demandando "otras" formas reconstrucción de "lo nacional", la iconografía del Gaucho Gil -fuertemente deudora de los arquetipos de la nación integracionista- se abre a re-articulaciones que propician los sujetos desde sus diversas posiciones al investirlas de sentido.

\section{La construcción de una iconografía móvil y performática}

A lo largo del desarrollo de este capítulo, hemos observamos cómo la iconografía del Gaucho Gil, analizada desde la propia imagen central (el gaucho sobreimpreso a una cruz con predominancia de los tonos rojos) que prolifera a través de diversas materialidades y textualidades inmersas en las prácticas religiosas y extrarreligiosas, posee una eficacia pragmática que está ligada a sus cualidades icónicas-expresivas y rasgos hipercodificados. Estos rasgos se actualizan fluidamente en el devenir de las prácticas sociales y discursivas “asegurando un rápido reconocimiento en la recepción” (Cebrelli y Arancibia, 2008).

Asimismo, la imagen del "santo" popular textualiza "representaciones nodales" y plantea un poder sintetizador de significaciones densas (relatos orales, leyendas, textos fundadores de identidades/alteridades) que le otorgan la posibilidad de anclaje y reactivación desde la memoria colectiva después de largos períodos a través de distintas prácticas y discursos de la cultura argentina, desbordando incluso el ámbito de la religiosidad para instalarse en diversos repertorios de los medios masivos, en el comercio y en el arte.

Estos elementos llevan a que la representación iconográfica central en particular y las representaciones e imaginarios del mundo iconográfico del Gaucho Gil en general planteen un poder performativo en el orden pragmático-discursivo. No obstante, entendemos que esta dimensión no puede ser abordada sin tener en cuenta la construcción de "íconos - emblemas móviles” que, según Segato $(2007,2008$,) caracteriza a las religiosidades contemporáneas.

Segato señala que en este tiempo las religiosidades responden a un "nuevo orden territorial" donde "el territorio pasa por desprenderse de anclajes materiales fijos y adquiere movilidad" y donde la iconicidad se configura como formateadora no sólo de los cuerpos y las identidades, sino también de los territorios. Para la autora, el pueblo parecería dejar de definirse estrictamente como "un conjunto de habitantes de un territorio geográficamente 
delimitado" y pasa a plantearse como "un grupo que porta la 'heráldica' de una lealtad común $y$, con esto, instituye un territorio en el espacio que ocupa" (Segato, 2007: 313).

La construcción y circulación de imágenes a modo de "heráldicas" en el caso del Gaucho Gil es recurrente y también se encuentra signada por poblaciones devotas migrantes y por el incremento de "actividades comerciales ambulantes y fronterizas" prácticas devocionales. Por un lado, la actividad de los devotos camioneros abocados al comercio interprovincial y trasnacional que llevan consigo estas insignias de fe (la iconografía del gaucho, las cintitas o las banderas rojas) e implantan altares a la vera de los caminos a modo de cumplimiento de una promesa; también se puede contar dentro de este grupo a los remiseros. Ellos, además de mostrar, transportar el "ícono-emblema" del "santo" popular suelen llegar a su santuario los ocho de enero a dejarle placas de autos y a pedir la bendición de sus nuevos móviles.

Por otro lado, se encuentran los vendedores ambulantes que desarrollan sus negocios en el seno de los santuarios ya instaurados y las peregrinaciones en fechas conmemorativas. Este grupo utiliza la imagen en términos de su condición de "logo-marca", porque más que una motivación de fe persigue un rédito económico, aunque se cuentan algunos testimonios que combinan ambas motivaciones.

Otro grupo conforman los artistas y periodistas devotos y/o simpatizantes que se han ocupado a través de sus creaciones de llevar la imagen del Gauchito a todas partes. Se encuentran testimonios de músicos clásicos o de rock, cumbia, chacarera, chamamé; artistas visuales, conductores de tv, periodistas; quienes también van construyendo sus trabajos en el viaje y en los pasajes ya sea físicos o virtuales. Con ellos sobre todo, el Gaucho Gil se convierte en una figura donde la adhesión incluso excede lo religioso, lo contamina con inquietudes, motivaciones y lenguajes de otros campos.

De este modo, las formas de construcción de sentidos en torno al Gaucho Gil no se restringen al epicentro de la celebración central que se realiza en Mercedes, aunque este espacio no deja de ser el más importante, tampoco dejan de ser trascendentes los altares y

${ }^{111}$ Krautstofl desde su estudio de las "paseras", trabajadoras trasnacionales de la frontera paraguayo argentina Posadas- Encarnación observa un incremento de las actividades comerciales fronterizas en los últimos años y señala que estas constituyeron "un colectivo de especialidades de pasero/as que compiten en y por espacios de compra y venta". En un intento de clasificación, habla de las paseras tradicionales, modernas, bagalleras; también motoqueros, taxistas, cambistas, entre otros. El análisis de la antropóloga busca "ligar el modo sociocultural del trabajo como condicionante de la percepción del cuerpo vivido y objeto de in - corporación de mercancías " (Krautstofl, 2014). Esta reflexión, con focalizaciones diferentes a las realizadas en esta tesis, permite comprender al cuerpo como espacio que "representa un modo de ser en su mundo ampliado de relaciones" que marca territorio en su recorrido. Como las paseras rodeadas de canastos y productos, con la mercancía en su cuerpo; los devotos, promeseros, comerciantes ligados al Gaucho Gil, transportan íconos, construyen pertenencias desde esas iconicidades en el andar. 
capillitas como redes de inscripción de fe y memoria, y además estas formas se propagan articuladas a la difusión de inscripciones iconográficas en los cuerpos, los accesorios que los devotos/simpatizantes transportan y los medios diversos.

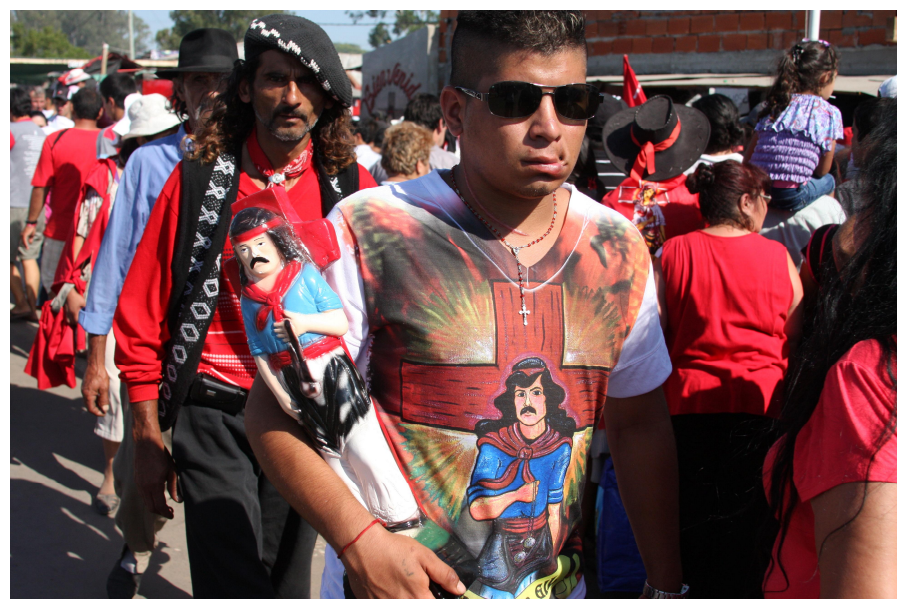

Juan Pablo Faccioli. S/T, Mercedes, 2012. Col. Faccioli.

Así, podemos observar que las iconicidades en su desplazamiento propician relaciones complejas en términos de "comunidad-ritualidad e iconicidad religiosa-territorialidad" (Segato, 2008)". Sin embargo, vale señalar que los "íconos-emblemas" son concebidos por Segato, siguiendo a Durkheim, como "símbolos reducidos, de baja densidad" históricacultural, en tanto son sometidos a un proceso de simplificación para convertirse en un esquema de síntesis gráfica de fácil reproducción.

Esta característica hace, por ejemplo, que un símbolo denso como el de la figura del Gaucho Gil pueda ser reducido a una estampa o stiker de "moda" y funcionar como adhesivo de autos, otras propiedades y objetos. En esta vía, incluso puede ser transformado en algo “cool”- como plantea Frigerio (2015) en su análisis de Iemanjá- y ser reutilizado como recurso de la publicidad y el marketing ${ }^{112}$.

Asimismo, esta iconicidad que implica en términos de Segato una "territorialidad móvil" como actitud religiosa muy presente en la devoción del Gaucho Gil y en el fenómeno de su expansión hacia terrenos extrarreligiosos, se concibe también como un elemento

\footnotetext{
${ }^{112}$ Un caso paradigmático es la reciente utilización de la imagen y el nombre del santo popular (Gaucho Gil) en la construcción de una marca de vino de exportación por parte de los viñedos Malbec para promocionar el día mundial Malbec en diferentes países extranjeros. En el esquema promocional se incorpora la leyenda hipersimplificada del gaucho milagroso para dar cuenta del componente "espiritual" de la variedad de la bebida presentada, una figura de Gil asimilada al del Gaucho Martin Fierro junto a las imágenes de la empanada y el vino que se suman a un espectáculo de tango, todos como emblemas de la "argentinidad". Ver más: http://www.bottleshopconcepts.com/gauchitogil
} 
atractivo para la prensa y las pantallas en general y en sí es alimentada por la sobrerrepresentación massmediática de los rituales.

Entonces, los “íconos-emblemas móviles” ganan las pantallas y fascinan desde la pura forma - presencia. Es decir, toda la atención del espectador y también del productor de imágenes (en tanto participa, construye y a la vez es modelado por esa imaginería) es capturada por la propia potencia de estos "íconos-emblemas" ambulantes que en su repetición, en su permanente remisión a figuras hipercodificadas, en su excesiva compulsión de "mostrar todo de manera recurrente y al modo espectacular" - como señala Imbert al describir el fenómeno de la hipervisibilidad- ocluye sus tramas históricas constitutivas y actúa "en detrimento de su intelección" (Imbert, 1999: 5-6).

Un caso ejemplar es el "ícono-emblema" del gaucho que, al adquirir condición de acto presente en distintas instancias de mostración, de reproducción y de imitación por parte de los propios fieles como pueden verse en las imágenes del corpus, también "oculta o disimula las convenciones" (Butler, 2002:34) de las que se vale para conformarse y reintroducirse en la cadena discursiva de imágenes circundantes.

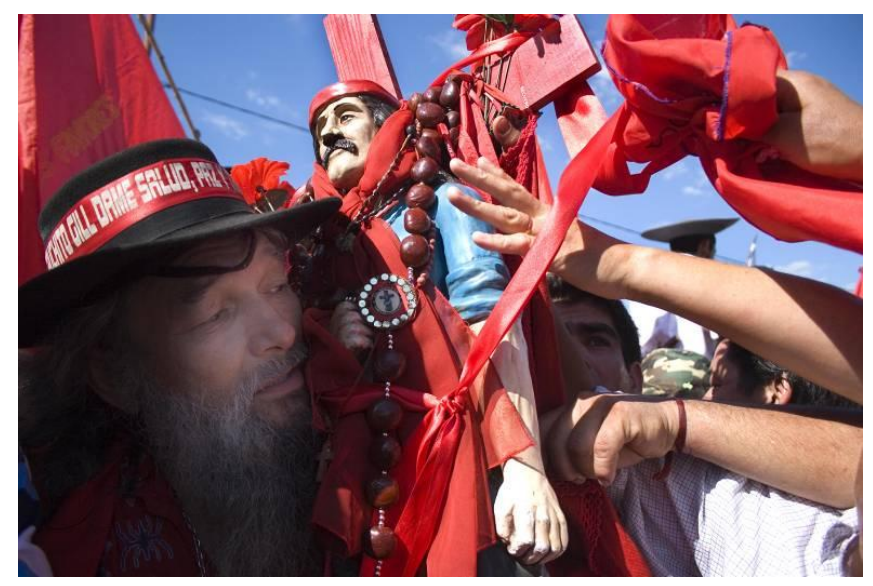

Guillermo Rusconi. S/T, Mercedes, 2011.Col Rusconi. Publicada en el Flikr del fotógrafo

Asimismo, el exotismo teatral y dramático de los rituales y las fiestas religiosas dimensiones especialmente exacerbadas en la festividad del Gauchito Gil- en tanto responden al dispositivo del rito que plantea elementos muy codificados y con fuerte carga simbólica que trabajan para persuadir y reproducir valores, como señala Ticio Escobar manifiestan una potencia visual extraordinaria pero a la vez engañosa.

Pese a la dificultad resulta necesario "correr el velo" (Escobar, 2013), no confundir el rostro con la máscara (Martin-Barbero, 2002), trascender esa observación primera para 
atender a las mediaciones históricas e ideológicas que constituyeron a la figura del Gaucho Gil y su mundo iconográfico como signos representativos de una alteridad. Sobre todo porque reponer el debate sobre su densidad histórica es crucial para ampliar la mirada acerca de los factores de su adhesión popular, de su arraigo local-regional primero y nacional después.

Al respecto, en la línea de lo planteado Segato y ante la necesidad de revisar la complejidad y el espesor histórico que plantea este mundo iconográfico, vale señalar que así como la devoción plantea elementos de la "territorialidad móvil" más contemporánea donde el pueblo ya no se "sujeta" a un territorio, a su vez, los rituales entrelazan otras actitudes religiosas vinculadas al "esencialismo del territorio" y el "relativismo de la localidad"113, donde el lugar sagrado de origen cobra valor.

De este modo, por ejemplo, entre los devotos de Antonio Gil cobra importancia y centralidad el santuario en Mercedes, a dónde incluso los fieles que son administradores de otros santuarios en otras ciudades del país o quienes tienen a su alcance alguno en su barrio o ciudad buscan llegar el 8 de enero. Algunos señalan que cuando piden grandes favores se ofrece el viaje hasta Mercedes como ofrenda. Si bien aquí no se cumple la "visión esencialista del territorio" más fundamentalista (concepción desde la cual este punto de inscripción en el paisaje como lugar sagrado no podría ser replicado) sí, de todos modos, el santuario constituye el lugar sagrado de referencia central y, a la vez, descripto por los devotos como un espacio que es habitado y custodiado por el espíritu del Gauchito ${ }^{114}$.

Por otra parte, se puede notar que el "relativismo de la localidad" tiene presencia en las formas que adquieren los rituales en torno a este "santo" porque implican una red de altares, capillitas y santuarios que reinstalan en cada acto de veneración y re-memoración el territorio en que el Gaucho Gil fuera degollado, inclusive más allá del anclaje geográfico de origen. Cada uno de estos espacios se transforman en el santuario mercedeño "transustanciado", en términos de Segato (2008), donde la divinidad desciende, retorna de la

\footnotetext{
113 Estas actitudes religiosas, Segato las relaciona con una periodización: el escencialismo se corresponde al modelo feudal del gobierno del territorio en manos de un señor o monarca (hasta el s. XVIII); la relatividad de la localidad se vincula a modelo de gobierno de la población en un régimen pastoral, de la vida del grupo humano que se asienta en un determinado territorio (desde s.XIX) y finalmente, la territorialidad móvil se plantea como un fenómeno actual.

114 Al respecto, una de las leyendas sostiene que la cruz originaria junto al cuerpo de Antonio Gil estaba enterrada en una estancia privada. El dueño habría mandado a mover la cruz y a trasladar el cuerpo del difunto. Luego de ello, cuentan que Gil se le aparecía en sueños pidiéndole regresar al lugar donde estaba. El propietario, a punto de enloquecer por las apariciones y también subsumido en el alcohol, le habría erigido finalmente el monolito donde actualmente se encuentra el santuario y como corolario cesó su perturbación. Por otra parte, documentos y testimonios fehacientes indican que el trazado de la actual ruta nacional 123, que se construía por la década de 1970, debió moverse unos metros porque respetar la planificación original implicaba pasar casi sobre el santuario y ningún trabajador quería padecer la persecución del alma que custodia el lugar.
} 
muerte, se hace presente cada 8 de enero que se le venera y los días de rezo e invocación estipulados por los rituales. De este modo, el discurso religioso del Gaucho Gil relativiza la localidad.

En definitiva, la mixtura de formas de inscripción, demarcación de las filiaciones identitarias comunitarias-religiosas-territoriales complejizan aún más la interpretación del mundo del Gaucho Gil. Por un lado, este mundo conserva actitudes religiosas en relación al territorio que responden a lógicas de formaciones culturales pre-modernas y que nos hablan de una memoria popular de larga data con fuerte incidencia en la configuración de las prácticas rituales actuales; mientras por otro lado, plantea "íconos-emblemas móviles" y performáticos que hablan del índice de transformación relevante que Rita Segato identifica en la configuración de las religiosidades contemporáneas y que presenta índices de la reconfiguración de los rituales, deslocalización de sus símbolos, reproducción y apropiación de los mismos en ámbitos incluso extrarreligiosos, con fines diversos.

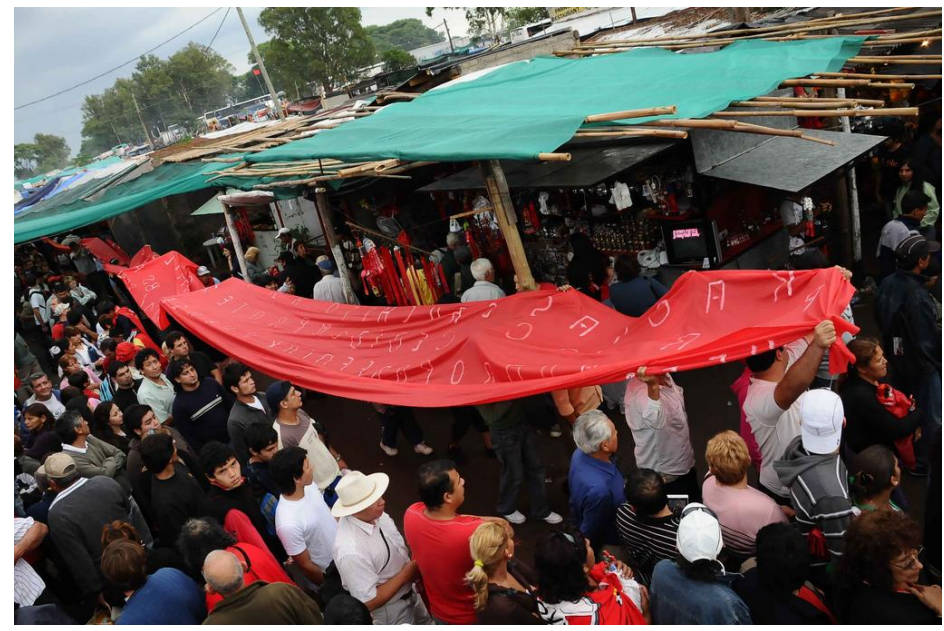

Banderas rojas a tu corazón. Juan Pablo Faccioli. Mercedes, 2009. Publicada en Agencia Corrientes, 9/1/2009 y Flickr del fotógrafo.

\section{El Gauchito iconográfico y fotogénico en la mirada de los fotógrafos}

Hacemos mención a los procesos en que la iconicidad móvil así como el alto grado de expresividad gestual y corporal hipercodificados configuran la festividad del Gaucho Gil porque comprendemos que estos elementos inauguran algunas vías para comprender la preferencia o la atracción manifiesta de los fotógrafos en retratar diferentes dimensiones de este fenómeno de religiosidad popular. 
El fotógrafo y crítico de fotografía español, Francisco Sánchez Montalbán, en su interpretación de fotografías de ritos religiosos católicos rescata: "es posible que Dios, padre, hijo y demás compañías sean en verdad seres fotogénicos” (Sánchez Montalbán, 2004: 670 ) En su argumentación el autor insiste que esa "fotogenia" está cimentada en una iconografía religiosa que fue calando de a poco en la experiencia de las sociedades predominantemente cristianas y católicas, como sucede en el caso de España y también de la Argentina. Entiende que esta iconografía fue modelando las formas de ver, mostrar(se), concebir la realidad y también los modos de fotografiarlas. En este sentido, señala:

\footnotetext{
"El rito, la fiesta religiosa de contexto y fundamento católico, sabemos por experiencia, nos ha acompañado durante nuestra vida, más o menos constantemente, como parte de ella, como pegajoso compañero e incansable condicionador de nuestras opiniones, gustos y actividades; a veces sin quererlo(...) Me atrevo a suponer, a priori, que todo elemento religioso es parte integrante de la cultura de un país; no digo que esto pueda ser bueno o malo, pero seguro que condiciona y perfila el carácter de esa sociedad y de sus individuos" (Sánchez Montalbán, 2004: 671 ).
}

El autor plantea que la "fotogenia" está ligada a un componente de "arraigo cultural" de la iconografía religiosa por la que esta se actualiza y refiere permanentemente en cada práctica de fotografiar y re-presentar la realidad. Sostiene que en este marco el fotógrafo busca en algún potenciar los valores expresivos y simbólicos que vehiculiza el acontecimiento religioso, o bien, hacer uso de estos elementos como recursos para plantear distanciamiento o alguna crítica.

En definitiva, señala que todas las creaciones, inclusive las fotográficas, si bien están condicionadas por procesos psicológicos de la percepción; conllevan una significación de anclaje cultural, o sea, están condicionadas por el contexto y la herencia cultural, donde lo religioso se erige como "un protagonista temático, de fondo, en muchas de las creaciones artísticas de nuestro siglo" (Sánchez Montalbán, 2004: 671).

Entre los factores que potencian el atractivo de los rituales para las cámaras fotográficas, el autor rescata que: "el elemento religioso" -como portador de valores plásticos y estéticos - "es un recurso expresivo" potente para la foto porque actúa como "estímulo visual" que es "capaz de incidir en el contexto cultural y en el espectador"; "el acto ritual en sí funciona como simulacro y es el espectáculo y la recreación teatral la que justifica la imagen", donde incluso es posible fotografiar actos que connotan relaciones complejas donde los participantes, devotos se divinizan, es decir sustituyen en sus actos performáticos dentro de los rituales a la divinidad (por ejemplo la imitación); y la "exuberancia del rito y el festejo" como receptáculos de "escenas de alta concentración expresiva" que el fotógrafo puede 
utilizar para "dotar a su obra de componentes estéticos llenos de sugerencia y fascinación" (Sánchez Montalbán, 2004: 680-687).

Todos estos elementos identificables en las procesiones, romerías o misas católicas también están presentes en los rituales del Gaucho Gil, donde el componente religioso cristiano y católico como vimos en los análisis representaciones anteriores está fuertemente arraigado. Sin embargo, por la imbricación de sus prácticas rituales con matrices de la cultura popular, esta festividad pone de manifiesto otros elementos expresivos: aquellos que se desprenden de la relación de los fieles con la divinidad marcada por la proximidad y también por la informalidad; rituales donde las normas, la parsimonia y el estatismo de las mediaciones burocráticas del dogma son muchas veces dejadas de lado para dar lugar a manifestaciones aún más irracionales y emocionales.

En este sentido, Eduardo Longoni quien realizó la producción documental en enero de 2013 que más adelante abordamos, describe a la celebración del Gaucho Gil como "una nueva forma de fe. Una fe que no es recatada, una fe bestial” (Longoni y Piccini, 2013).

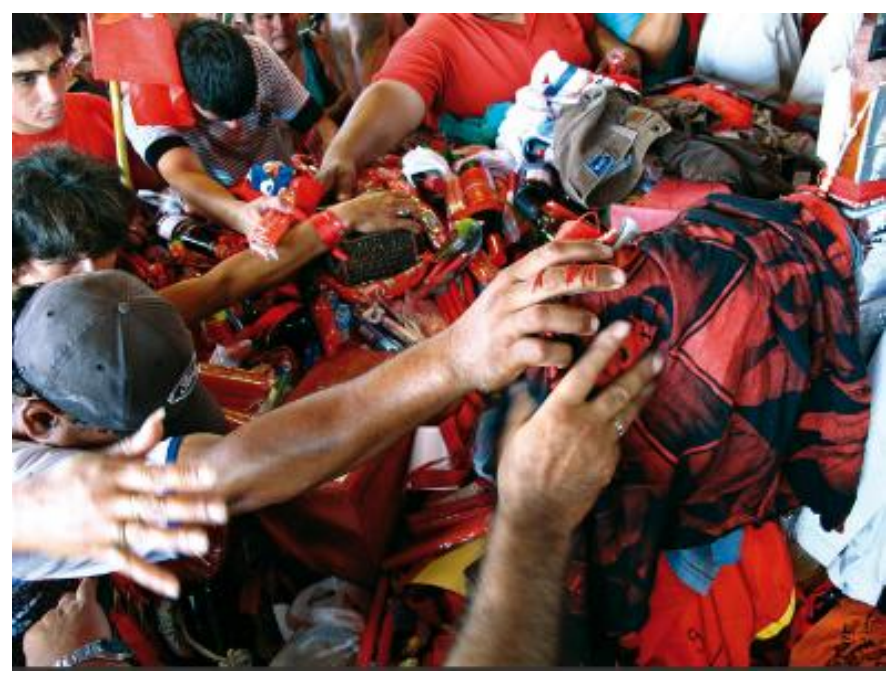

Eduardo Longoni. Ensayo. La Fe en la Piel. 2013

Es esa exhibición del exceso también sintetizado en la propia figura del Gaucho Gil que a su vez convoca a Marcos López que apropiarse de la imagen del "santo" popular y reconfigurarla en su obra de la serie "Subrealismo criollo", asociándola no sólo con signos de la identidad argentina, sino sobre todo del imaginario barroco y melodramático latinoamericano.

Así como hay indicadores del barroco y el melodrama latinoamericano operando como condicionantes en la práctica de fotografiar y recrear la figura y la festividad del Gaucho Gil, 
también el color rojo por todas partes, saturado, participa como elemento activo en las creaciones, sintetizando y sugiriendo espíritu festivo exacerbado, lo reacio, lo salvaje y lo vibrante. Esto lleva a Eduardo Longoni y también a Estela Izuel quienes venían trabajando en película blanco y negro a dar rienda suelta en sus obras a la furia propia al rojo el color del Gauchito, aunque con enfoques e intereses diferentes.

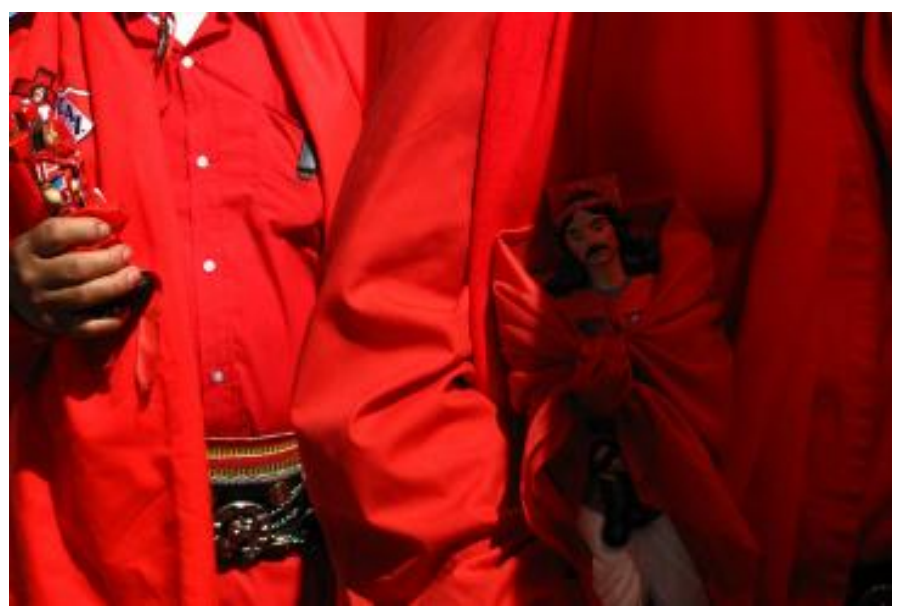

Eduardo Longoni. Ensayo. La Fe en la Piel. 2013.

Respecto a este pasaje en la apreciación del color Estela Izuel recuerda: "Yo había comenzado a hacer mis fotos de los santuarios en blanco y negro hasta que encontré al Gauchito Gil y el Gauchito Gil es todo rojo; entonces pensé que me estaba perdiendo algo, entonces decidí viajar con película a color, seguí haciendo tomas en blanco y negro y color, pero después seguí a color” (Entrevista a Izuel, 2015).
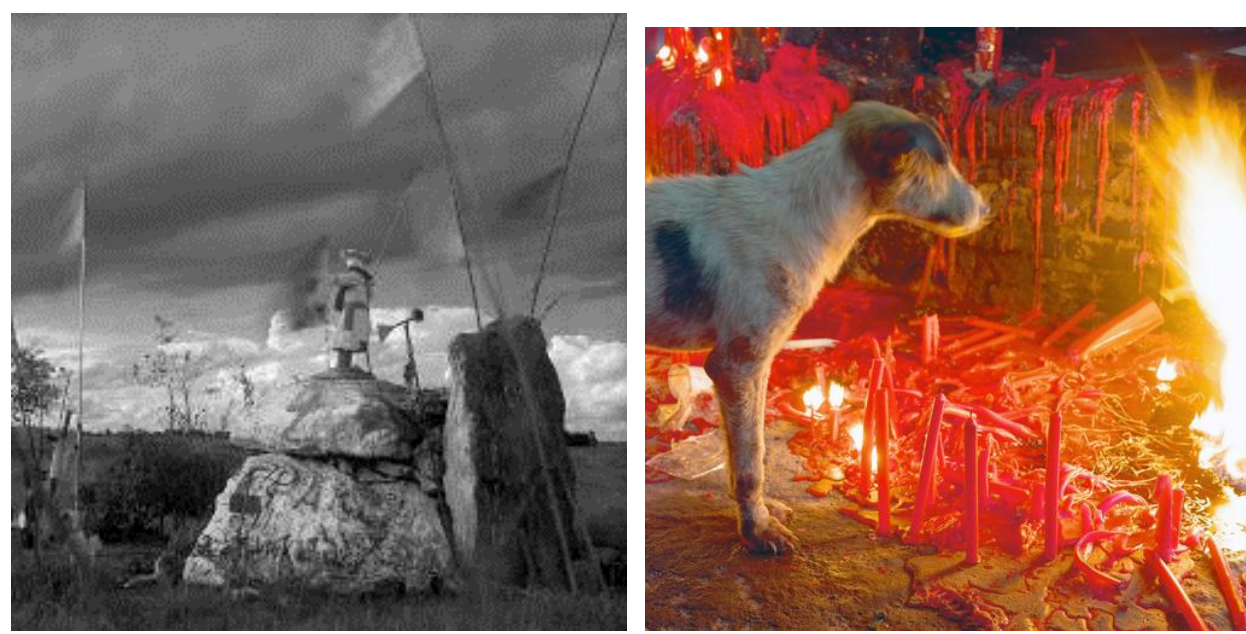

Estela Izuel. Ensayo. Gauchito Gil. 1999 
También los jóvenes fotorreporteros Guillermo Rusconi y Juan Pablo Faccioli, cuyas imágenes aquí presentamos y luego retomaremos, coinciden en que "el Gauchito es altamente fotogénico" (Entrevista a Faccioli y Rusconi, 2013). Los fotógrafos relacionan este carácter con la espesura de la simbología (velas, banderas, estatuillas, tatuajes), que rodean y conforman los cuerpos y los rituales de la festividad, así como con la expresividad propia del rojo y agregan una cualidad más: la predisposición de los participantes a ser fotografiados.

En este sentido, la actitud de los retratados en el intercambio con el fotógrafo también define las escenas fotografiadas y aparece como elemento clave de la construcción del "Gauchito fotogénico" en la visión de los fotógrafos. Guillermo Rusconi sintetiza: "Estar en el Gauchito es muy fuerte a nivel personal por la mística particular que sobrevuela en el aire los días de la fiesta y también a nivel imagen por la simbología (...) por esa marea roja inundando todos los espacios y por la expresividad de la gente. Vos vas y la gente te ve con la cámara y ya te cuenta su historia y se muestran orgullosos de ser fotografiados, algo que no sucede con otras festividades" (Rusconi, 2013).

En resumen, hablar del "Gauchito iconográfico y fotogénico" desde la mirada de estos autores y las búsquedas de sus producciones implica la conjugación de una fuerte simbolización y diversas remisiones a retóricas expresionistas y melodramáticas ${ }^{115}$ pero también remite a lo que Jean Epstein y Louis Delluc concebían como fotogenia para pensar "lo cinematográfico"; es decir, el modo en que se expresan las cualidades poéticas de las cosas y las personas.

Desde esta visión se insistía no en hacer hincapié en una narración, una historia lo más realista posible o en hacer creer al espectador que lo que se cuenta no ha sido construido, sino más bien en potenciar a partir de la construcción de la mirada la cualidad plástica de la imagen y su capacidad para transmitir la sonoridad interior de los objetos, las escenas, sugerir sensaciones, sentimientos.

Esta perspectiva denominada "visualismo", según Aristarco siguiendo a Delluc, comprende "el conjunto de atmósfera y dramatismo, de psicología y cosas dichas o sugeridas por imágenes y detalles de las mismas, fotografiadas no aisladamente como encuadres maravillosos o alardes de la cámara, sino apropiados para crear estados de ánimo y emociones interiores, precisamente por medio de una fusión intima" (Aristarco, 1968). También es un

${ }^{115}$ La configuración melodramática en las fotografías de prensa que forman parte del corpus central de análisis es indagada en el Capitulo 6. 
punto de vista que se declara en contra de la estética del quietismo, lo estable, lo racional y lo ordenado para dar lugar a lo inestable, lo dinámico desde el estudio del montaje, el movimiento, la manipulación de lo real apuntando a huir de la mímesis.

En esta línea, puede leerse en los capítulos siguientes el modo en que las fotografías de los rituales de los autores analizados con condiciones de producción e interpretación también cambiantes, reconfiguran las formas de ver y dar a ver los rituales y se despegan de la visión eclesiástica estática y panorámica de las procesiones de los cultos oficiales o de los retratos de los personajes de la jerarquía eclesiástica para dar lugar a visibilidad de la religiosidades "otras", la densidad atmósfera socio-cultural de la religiosidad popular, sus bordes y los excesos y sus interacciones con campos extrarreligiosos, la exaltación de las relaciones afectivas entre devotos y la divinidad, los retratos de los sujetos en acción, entre otras propuestas.

Así también la fotografía de rituales, y aún más exacerbado en el caso de las imágenes del Gaucho Gil, experimenta un corrimiento de la fotografía realista del siglo XVIII, XIX y buena parte del siglo XX para dar lugar en el siglo XXI a una fotografía que dialoga con el melodrama teatral y cinematográfico, el lenguaje pictórico y otras formas escénicas. 


\section{CAPÍTULO 4:}

Foto, memoria y religiosidad correntina. La configuración de miradas hegemónicas

El recuerdo histórico no es una reserva estática de significaciones definitivamente consignadas en los archivos del tiempo. La actividad de la memoria surge del deshacer y rehacer de los procesos de evocación y narración del pasado al que nos convocan las solicitaciones políticas y comunicativas de un presente curioso, o bien disconforme.

Nelly Richard, Fracturas en la memoria. Arte y pensamiento crítico

Políticas de in-visibilidad alude a ese conjunto de tácticas y estrategias de tácticas que, de manera cotidiana, gestionan la mirada, esa que produce efectos sobre el modo en que percibimos y somos percibidos, esa que clausura y abre otros caminos, esa que reduce o esa que restituye complejidad. Politicas de la vida cotidiana que "no vemos" porque a través de ellas, vemos

Rossana Reguillo, Políticas de la (In)visibilidad. La construcción social de la diferencia

Pensar la construcción de re-presentaciones fotográficas de la religiosidad correntina en relación a la noción de memoria implica indagar en los lugares desde donde se construyen las miradas y en las políticas de in-visibilidad que estas miradas comportan. En otras palabras, la indagación requiere reflexionar no sólo sobre aquello que muestran las imágenes sino cómo lo hacen ${ }^{116}$ en relación a una situación comunicativa específica en la que cada iconografía adquiere una dimensión ideológica y produce relaciones de negociación, conflicto y lucha por la desestabilización de las significaciones.

En ese sentido, las miradas no se conciben inocentes sino más bien como constructoras de formas de visibilizar e invisibilizar hechos, personajes, paradigmas e ideologías desde campos socio-culturales complejos, atravesados por relaciones de fuerza y dominación.

En este marco, la imagen que observamos en una fotografía -ya sea con existencia material física o digital, virtual- es posible por la construcción de cierta mirada que retiene un fragmento de lo fotografiable y deja fuera de campo otro, respondiendo a ciertos regímenes de in-visibilidad. Así, en el momento en que se produce el orden de lo visible también se produce el orden de lo invisible y esta elección/ recorte está condicionada por modalidades históricas y culturales de mirar, mostrar y ocultar. Como señala Grüner toda mirada es

${ }^{116}$ Esto también se relaciona con la indagación sobre ¿qué quieren las imágenes? que desarrolla W.J. T. Mitchell (2003). 
“construida en un específico lugar” y “está en estado de sitio, constreñida por las estructuras sociales, ideológicas y culturales de la sociedad a la cual esta mirada da una particular preferencia" (Grüner, 2002: 2).

Los "sitios" y "estados de sitio" de la mirada a los que hace alusión Grüner son lo que Reguillo denomina "regímenes de visibilidad". Se trata de marcos de regulación configurados a partir de complejas construcciones socio-históricas que se articulan: "1) formaciones históricas particulares (... 2) instituciones socializadoras e intermediarias que la modelan y modulan (...) y 3) lógicas de poder político que devienen en poder cognitivo (...)" (Reguillo, 2008: 2).

No obstante, esas normas regulatorias no son invariables y estáticas sino que pueden ser transformadas por acciones sociales y situaciones históricas y culturales cambiantes. Estas condiciones no sólo "vuelven amenazantes los mundos de la visibilidad" establecidos, como asevera Reguillo, sino que activan zonas de las memorias discrepantes ocultadas. En esos intersticios se constituyen espacios de "indeterminación" donde es posible hallar otros modos de mirar que cuestionan, o simplemente se diferencian del relato ordenado de la historia consensual para dar a ver la historia del disenso, la "contingencia rebelde al orden" (Richard, 2007: 211).

En esta línea, este capítulo analiza cómo algunas fotografías capturadas durante la primera mitad del XX (1900-1930) y puestas a circular a través de ciertos dispositivos vinculados al Estado, la Iglesia y otros grupos de poder, construyeron representaciones hegemónicas de la religiosidad correntina.

También indaga la des-estabilización de estas "visiones de mundo" a partir de una serie de transformaciones socio-culturales y la emergencia hacia fines de ese siglo y principios del siglo XXI (1980-2000) de repertorios y formas de construir visualidades diversos entre los cuales se hallan algunos que naturalizan y actualizan las representaciones establecidas, pero también otros que propulsan búsquedas de variantes en torno a la reproducción del "sentido común hegemónico" (Caggiano, 2012).

En ese sentido de lecturas, el ordenamiento de este texto plantea en un primer ingreso una discusión teórico-conceptual sobre las políticas visuales ligadas a la construcción de la mirada y la memoria en las prácticas de captura y archivo de fotos. Allí se comparan los procedimientos de construcción de la fotografía y del archivo fotográfico como dispositivos productores sentido, cuyos roles se consideran vitales en el proceso configuración de memorias y representaciones identitarias, en general, y sobre el tema abordado, en particular.

El segundo ingreso de lectura se centra en el análisis de fotos históricas producidas 
durante el siglo $\mathrm{XX}$ en relación a los modos y ámbitos de construcción de las miradas y memorias característicos de la formación discursiva en la que se insertan. El escrito inicia con la descripción de la búsqueda de fotografías históricas de religiosidad correntina en archivos provinciales y nacionales, incluyendo reflexiones sobre lo visto y no visto de las fotos reguardadas y sus modos de valoración social. Luego se realiza un análisis focalizado en fotos históricas del tópico de interés capturadas entre 1900 y 1969 que presentan los álbumes del Centenario argentino conservados en el Museo Histórico de Corrientes y algunas cajas de imágenes halladas en el Archivo General de la Nación (AGN).

Finalmente, el tercer apartado se contrastan las visiones de la religiosidad correntina que vehiculizan las fotografías históricas resguardadas en los álbumes y archivos analizados con las otras formas de reproducción, actualización y re-configuración de dichos repertorios a través de la prensa tradicional, especialmente la prensa gráfica y luego los denominados "nuevos medios" de circulación global. Respecto a esto último se abren algunas inquietudes en torno a los modos que estas nuevas formas de producción, circulación, consumo y reproducción de imágenes exigen re-pensar las formas de construcción de miradas y memorias colectiva.

\section{Políticas visuales y prácticas de captura y archivo de imágenes}

Nelly Richard (2007) señala que toda actividad de re-memoración surge de las demandas sociales, políticas, comunicativas de "un presente curioso, o bien disconforme". En nuestro caso, y teniendo como principal foco de interés el análisis de fotografías contemporáneas en las que nos detenemos en el siguiente capítulo, la inquietud de indagar en los archivos históricos de documentación fotográfica y sus modos de funcionamiento en tanto dispositivos de memoria surge de la necesidad de rastrear las representaciones visuales de una devoción que según los relatos orales surge a mediados de siglo XIX (con la muerte de Antonio Gil alrededor de 1878) pero que, por lo observado, recién se visibiliza con fuerza un siglo después, entre 1980 y 1990.

Ese dato y el objetivo de indagar en el "espesor temporal" de las representaciones (Cebrelli y Arancibia, 2005; 2008), así como reconocer de los modos en que unos conjuntos visuales centrales adquieren valor en relación con otros y ligados a la dinámica de producción de sentidos de dispositivos específicos ${ }^{117}$, nos llevó a relacionar a las imágenes actuales con

${ }^{117}$ Esta noción es desarrollada en el Capítulo 1. 
un campo discursivo más amplio incluyendo para el contraste fotografías históricas y otros textos asociados.

Así se construye una investigación que analiza de qué manera los conjuntos fotográficos se configuran productores de sentido dentro de formaciones que, como lo señalara Foucault, incluyen "discursos, instituciones, instalaciones arquitectónicas, decisiones reglamentarias, leyes, medidas administrativas, enunciados científicos, proposiciones filosóficas, morales, filantrópicas, brevemente, lo dicho y también lo no-dicho" (Foucault, 1977, en Agamben, 1991). En ese sentido, las líneas que siguen reflexionan sobre las operaciones claves compartidas por el archivo y la fotografía como dispositivos productores de miradas y memorias.

\section{1.a) Procedimientos de ordenación/clasificación de miradas y memorias}

La conformación de lo que Anette Wieviorka denominó "la era del testigo" (1998) y lo que Andreas Huyssen llamó “el boom de la memoria” (2001) $)^{118}$, promovió en la contemporaneidad un giro de las reflexiones hacia el pasado y volvió a poner en discusión los alcances y límites de los géneros discursivos y dispositivos/espacios/medios utilizados para la reconstrucción del recuerdo, entre los que también se hallan la fotografía y el archivo ${ }^{119}$.

En el caso particular de la fotografía, su recuperación y resguardo siempre estuvieron ligados a su concepción como documento y evidencia histórica por funcionar en determinados contextos "como una especie de prueba" de lo acontecido (Tagg, 2005: 90). En este sentido, Fontcuberta sostiene que "la facultad de atestiguar lo que ha sido, de retener lo que se desvanece es la memoria” (Fontcuberta, 1997: 56). Mientras que Strelczenia (2004) agrega que "tanto nuestra noción de lo real como la esencia de nuestra identidad individual dependen de la memoria. No somos sino memoria". Asimismo, la autora señala que "la vida es en esencia movimiento y transformación. Pero sólo podemos tomar conciencia del movimiento

\footnotetext{
${ }^{118}$ Huyssen plantea que los discursos de la memoria se intensificaron en Europa y los Estados Unidos a comienzos de 1980 activados por el debate sobre el Holocausto, con resonancia global a partir de su mediatización y el auge de los testimonios. En este sentido Wieviorka agrega que "la guerra de 1914-1918 marca el comienzo del testimonio de masas", e interpreta que a partir del juicio a Adolf Eichmann (responsable de la solución final y de los deportados a los campos de concentración Nazi) la memoria del genocidio se erige como un elemento fundador de la identidad judía y marca un punto de inflexión en los juicios al considerar el relato de los testigos como prueba de peso además de los documentos escritos. Los autores, en otros términos, señalan que a partir de los sucesos lamentables enmarcados en diversos regímenes se creó la necesidad de dejar testimonio de lo sucedido a fin de crear una conciencia crítica que tienda a evitar la repetición de los procesos de violencia.

119 También podemos ubicar aquí a los medios masivos de comunicación. Parte del rol de estos medios en los procesos de re-memorización y de re-producción de representaciones sobre la religiosidad correntina es tratado en mayor detalle en el apartado 3 del presente capítulo
} 
en comparación con lo que permanece inmóvil”' (Strelczenia, 2004:76).

Por ello y a fin de dar cuenta del proceso de configuración de representaciones visuales de la religiosidad correntina, insistimos en repensar el encuentro con esa mostración del pasado que ofrecen las imágenes históricas en el contraste con las representaciones contemporáneas, siempre teniendo en cuenta su contexto, las condiciones de producción y reconocimiento.

En este marco, entendemos que la consideración de la construcción de la fotografía como la del archivo que la resguarda juegan un papel central en la indagación, en tanto ambos dispositivos se conciben desde operaciones intrínsecamente ligadas a la fragmentación y la reordenación de las fracciones discursivas resultantes de dicha segmentación.

Allan Sekula, quien abordó problemáticas específicamente ligadas a los acervos fotográficos, señala que "los procedimientos y ambiciones del archivo están presentes en toda práctica fotográfica" (Sekula, 1986: 3-64, en Guasch, 2011: 168). Por ello, entendemos que es tan importante la fotografía en la concepción del archivo como el modelo de éste último en la construcción del discurso fotográfico.

Por un lado, la fotografía se constituye a partir del concepto que precede la acción de fotografiar - construcción de la mirada-, ostentado el poder de recortar, construir una realidad a ser conservada para la posteridad; y por el otro, el archivo configura un fondo documental a partir de la acción de resguardar aquellos recortes de lo real siguiendo parámetros de clasificación y conservación de algunas imágenes, que a su vez, implican el desecho de otras. Se produce así una especie de doble recorte, de filtro en estas prácticas atravesadas por diversas condiciones e intereses en dos instancias claramente diversas (captura y archivo de imágenes),

Siguiendo las relecturas y los cuestionamientos realizados oportunamente por Foucault a aquella noción de archivo que posee la aspiración de contener "un estado del mundo", aquí nos interesa resaltar los límites y las exclusiones de las representaciones de los archivos y las imágenes, siempre vinculándolos a una práctica discursiva, a su vez, atada a condiciones de posibilidad enunciativa. Es decir, se hace hincapié en entender a estos dispositivos justamente como algo construido, y por ende, no neutro ni ingenuo, condicionado por intereses diversos.

$\mathrm{Al}$ respecto, consideramos que el discurso fotográfico y el archivo de documentación fotográfica, en tanto se constituyen a partir del recorte y la fragmentación de realidades más complejas, operan como el archivo material descripto por Foucault (1991). Es decir, se plantean ambos como espacios producción y circulación de memorias que se construyen a partir de reglas que de-limitan lo que puede o no mostrarse, así como los modos de 
mostración en una época dada.

Sobre la preponderancia del régimen regulatorio, Foucault insiste que el archivo "es en primer lugar la ley de lo que puede ser dicho, el sistema que rige la aparición de los enunciados como acontecimientos singulares"; pero asimismo plantea que su particular construcción arquitectónica es la que ordena, "lo que hace que todas esas cosas dichas no se amontonen indefinidamente en una multitud amorfa, ni se inscriban tampoco en una linealidad sin ruptura, y no desaparezcan al azar sólo de accidentes externos" (Foucault, 1991: 222).

Por su parte, Marcelino García resalta que lo más perturbador en el archivo paradojalmente no es la cuestión de conservación del pasado sino la proyección del/lo porvenir; es decir, que instaura, el deseo compulsivo, repetitivo y nostálgico de "retorno de/a lo arcaico", que posee la capacidad de condicionar los imaginarios ${ }^{120}$ futuros, a partir de la puesta en práctica de la operación archivística. Entonces, el autor plantea que la trascendencia política de los archivos reside en:

\begin{abstract}
“(...) su práctica de almacenamiento, acumulación, preservación; como principio de autoridad que sanciona el valor, esto es la significación, de lo que sí se guarda; como institución cuyas funciones e incumbencias consisten en la impresión, re-impresión, supresión, des-comprensión, represión de las marcas, las huellas, los anagramas de la memoria" (García, 2004: 116)
\end{abstract}

\title{
1.b) La foto y el archivo, dispositivos productores de miradas y memorias
}

Lo expuesto evidencia cómo la operatoria archivística está signada por una política de ordenación/construcción; y la mirada imbricada en esta maniobra, por más bien intencionada que sea, produce "estados de comunidades nacionales" y "estereotipos identitarios", corriendo siempre el riesgo de constituir mapas representacionales sesgados de la realidad referencial heterogénea.

En otros términos, la reflexión sobre estos dispositivos (el fotográfico y el archivístico) nos lleva a examinar el lugar/sitio de la mirada (Grüner, 2002) para entender desde dónde, por qué y para qué esos mundos son imaginados y presentados/reproducidos en determinado momento y de determinada manera.

También esta construcción de la mirada manifiesta en la práctica fotográfica y archivística invita a superar aquellas nociones que vincularon históricamente a la fotografía y

${ }^{120}$ Los imaginarios configuran constructos sociales que se expresan por ideologías y utopías y también por símbolos, alegorías, rituales y mitos; estos elementos plasman visiones de mundo, modelan conductas y estilos de vida, en movimientos continuos o discontinuos de preservación del orden vigente o de introducción de cambios (Baczko, 1984: 54). 
al archivo sólo a la idea de fuente de evidencia documental.

Llegados a este punto, observamos que la fotografía como la institución del archivo, en tanto ejercen una función recordatoria y conmemorativa significativa, aportan elementos fundamentales para la consideración de la construcción de memorias.

Las memorias implican la interrelación de fragmentos provenientes de dos vertientes amalgamadas: la "memoria individual", ligada por ejemplo a la de aquel que aprieta el disparador de la cámara, pero que asimismo se ve inscripta en la memoria colectiva de un grupo de pertenencia social (relacionado con la construcción del "yo social"); y la que desde su origen se construye como un sistema de "memoria colectiva" que se nutre de las individuales y aspira a dar cuenta de una forma de conciencia del pasado desde cierta perspectiva compartida y consensuada por un grupo social (dado en el orden de lo institucional).

Dichas dimensiones marcan las correspondencias y distancias entre la fotografía y el archivo como espacios/medios de memoria, pero que a su vez se mixturan constituyendo marcas y marcos de contención y referencia de la memoria social ${ }^{121}$. De modo que estas dos vertientes en definitiva se condensan en ese recordar juntos al que refieren Middleton y Edwards (Middleton y Edwards, 1992: 23-27).

Asimismo, en sentido general, tanto la fotografía como el archivo pueden ser entendidos como "dispositivos de archivación" que cumplen una función de mediación ${ }^{122}$ entre el espectador o quien realiza una consulta y sus mundos de significados posibles.

Lo expuesto nos conduce a repensar los dos sistemas no como simples espacios de recuperación de memorias y conocimientos, sino como "artefactos culturales" (Stoler en Caggiano, 2012) e instrumentos de control social, porque tal como lo explicita García "producen y difunden información".

Entonces, la fotografía y el archivo como "dispositivos de archivación no sólo registran sino producen el acontecimiento" (García, 2004: 116). Mientras esa operatoria también la liga a su condición de sistemas de comunicación. Ellos se valen de diversas

121 Considerando el componente interpretativo del recuerdo, no pretendemos ni adherimos a una distinción tajante entre los conceptos de memoria individual y colectiva y rescatamos la memoria social como producto de un diálogo/ cruce entre las precedentes. "De la misma manera que toda experiencia vital de un individuo constituye una experiencia colectiva (Hosbsbawm, 1998). "No hay algo así como una memoria individual frente a una colectiva; ya que en un sentido, toda memoria es social" (Mudrovcic, 2005: 115). "No tiene sentido hablar de qué es la memoria individual comparada con la social [...] no se trata de categorías separables, sino que expresan relaciones de interdependencia y no se pueden emplear de forma reduccionista para explicar una en términos de la otra (Middleton y Edwards, 1992: 26)

122 En términos de Martín Serrano la mediación es definida "como la actividad que impone límites a lo que puede ser dicho, y a las maneras de decirlo, por medio de un sistema de orden" (Martín Serrano, 1976, en García 2005: 103) 
estrategias/operaciones/procedimientos de ordenación de la mirada (selección, recorte, y organización) para determinar la información del pasado que quedará disponible (archivado en una imagen, en una institución) para su consideración en el futuro. En esta instancia estos sistemas cumplen un rol fundamental "en el funcionamiento de los engranajes de saber y poder, las máquinas de creer, que también mueven y modelizan el cuerpo social" (García, 2004:116-117).

En resumen, retomando el concepto de dispositivo que Deleuze (1991) desarrolla a partir de Foucault, la fotografía y el archivo, en tanto son parte de una formación discursiva específica, se conciben como máquinas de hacer ver y hablar/decir ${ }^{123}$ condicionadas por regímenes de la formación que establecen qué se incorpora dentro del recorte fotográfico de lo memorable y qué se deja fuera, o qué memorias se hacen más visibles en el archivo y cuáles se dejan en penumbras. Así también la formación histórica instaura y maneja las líneas de enunciación que desde el orden del lenguaje generan formas de expresión, prácticas discursivas de selección, rotulación, catalogación y traducción dentro de los archivos o incluso de los medios que ponen a circular las imágenes fotográficas.

\section{Escenas de la religiosidad correntina in-dignas para fotografiar y resguardar}

Una primera aproximación a los espacios de difusión y resguardo de las fotos de religiosidad correntina nos devolvió el siguiente panorama: una superabundancia de fotografías contemporáneas - entre ellas referidas a la festividad del Gaucho Gil- capturadas a principios del siglo XXI presentes en archivos de fotos digitales de los diarios provinciales, también publicadas y exhibidas en la prensa y espacios de exposición artística, comparada a una escasez de fotografías del tópico religioso en general registradas durante la primera parte del siglo XX tanto en archivos históricos como en notas de prensa de la época.

Del contraste que devuelve una exuberante presencia versus una escasa presencia, surgió la necesidad de ahondar en las condiciones de posibilidad de esa exuberancia/escasez; es decir, indagar en las normas que regularon y regulan actualmente la captura, resguardo y mostración de las imágenes de prácticas religiosas correntinas en general. Esta reflexión se sitúa como el punto de partida para realizar luego una valoración acerca de la visibilidad expandida que adquieren las fotos de la festividad del Gaucho Gil, entre otras prácticas de religiosidad popular, hacia la década de 1980 en adelante, sobre todo entre 1990 y los años

\footnotetext{
${ }^{123}$ Mayor desarrollo conceptual ver apartado 2 del Capítulo 1.
} 
2000. Todo ello en el marco del fenómeno de la multiplicación de flujos imágenes en la Cultura Visual y su compleja relación con los modos de construcción de la memoria ${ }^{124}$.

\section{2. a) El mapeo de los acervos fotográficos: de la abundancia a la escasez}

En la búsqueda de fotos contemporáneas se visitaron los archivos fotográficos digitales de la redacción del diario La República -donde trabajó Guillermo Rusconi, cuya producción particular trabajamos más adelante-; el diario Época -donde trabajó Juan Pablo Faccioli, cuya colección también se aborda-; y los archivos de la sección de fotografía del diario El Libertador y El Litoral. En todos los casos, siguiendo el sistema de ordenaciones de las secciones a través de las cuales se publican las notas en los periódicos, ya sea Actualidad, Sociedad, La Ciudad e Interior, se encontraron carpetas y subcarpetas nominadas como Religión, Festividades o Fiestas Patronales con centenas de imágenes. Estas ordenaciones varían según los casos, pero en todos hay una gran abundancia de imágenes, sobre todo tomadas entre la década del 1990 y los años 2000, tanto de cultos católicos y casi a la par de prácticas de religiosidad popular, como las festividades de San La Muerte, San Baltazar y el Gaucho Gil.

Por otra parte, en el relevamiento de fotografías históricas de soporte papel y/o negativos se visitaron seis espacios: el Departamento de Documentos Fotográficos del Archivo General de la Nación (AGN), la Fototeca de la Biblioteca Nacional, el Núcleo de Estudios y Documentación de la Imagen del Instituto de Investigaciones Geohistóricas dependiente del Consejo Nacional de Investigaciones Científicas y Técnicas y la Universidad Nacional del Nordeste (NEDIM), la Fototeca del Archivo General de la Provincia de Corrientes, el Museo Histórico de la Provincia de Corrientes y el Municipio de Mercedes.

A diferencia de lo que sucede con los archivos de fotos contemporáneas de los diarios $^{125}$-en su totalidad de fotografías digitales-, en cada uno de estos centros de documentación visitados se encontraron escasas imágenes de la temática y la mayoría de ellas

\footnotetext{
${ }^{124}$ Respecto a esta problemática se pueden consultar: Huyssen, Andreas (2002). En busca del futuro perdido. México: Fondo de Cultura Económica; Rolnik, Suely (2010). "Furor de archivo". En Revista electrónica Estudios Visuales N. ${ }^{\circ}$ 7: 115- 129; entre otros.

${ }^{125}$ Cabe recordar también, que los diarios visitados son los de actual circulación. Dos de ellos surgieron en los años 90 y 2000 (El Libertador y La República), mientras los otros dos surgieron en los años 60 (Época y El Litoral. De estos, ninguno posee un archivo sistematizado de fotos históricas, ya sea en soporte papel o negativo, que date de la década de los 80 para atrás. Del acercamiento realizado y conversaciones con fotógrafos, se pudo saber que muchos han llevado algunos archivos a sus domicilios particulares, mientras algunos negativos se encuentran abandonados en los diarios. El Litoral, junto a un ordenamiento del archivo de los periódicos históricos, manifestó la intención de iniciar una recuperación de su archivo fotográfico.
} 
referidas al culto católico. En algunos de los espacios incluso no se hallaron imágenes; y de las halladas, sobre todo en la provincia de Corrientes, muchas estaban sueltas, incluso sin referencias, ni inventario y sin régimen adecuado de acceso para la consulta. En relación al sistema de ordenamiento, estos centros pueden describirse más bien como espacios de acumulación no organizada de fotografías y algunos casos con proyecciones a/ o en proceso de constituirse en fototecas. Al respecto, cabe señalar, que la situación no es exclusiva de los lugares visitados sino que responde al estado general de los acervos fotográficos de la provincia de Corrientes ${ }^{126}$.

El ejemplo más extremo en torno a lo visitado es el caso del Municipio de Mercedes, donde entre 2010 y 2011 se escanearon imágenes históricas proporcionadas en soporte papel por pobladores para realizar una exposición. Sin embargo, con las imágenes no se conformó un fondo disponible para la consulta. Hasta fines de 2014 la Dirección de Cultura no poseía archivo de fotos de ninguna clase; mientras que la Dirección de Turismo poseía algunas de imágenes actuales digitales para la promoción de la localidad pero no históricas. Por ello, imágenes históricas de la temática de interés en la localidad sólo fue posible observar en el seno de álbumes familiares hasta los que accedimos a partir del trabajo de campo realizado en la propia festividad del Gaucho Gil en Mercedes y el trabajo de un particular que inició el escaneo de imágenes otorgadas por vecinos y creó una página en la red social Facebook para compartir ${ }^{127}$.

Otros casos que resultan de interés a los objetivos de este análisis en Corrientes son el Museo Histórico Provincial y el Archivo General de la Provincia, ambos con asiento en la capital correntina, que durante las visitas realizadas (2010 y 2011 respectivamente) presentaban un inventario parcial, en el primer caso, y un proyecto de creación de fototeca, en el segundo caso, con un régimen irregular tanto para acceso al espacio de resguardo como para el servicio de copia de archivos para investigadores, a pesar que se tratan de centenarias instituciones dedicadas a la archivación de valiosa documentación histórica.

\footnotetext{
${ }^{126}$ Según señalan Isler y Giordano (2009) en su mapeo de colecciones fotográficas en la provincia, en general gran parte de las instituciones que guardan fotografías "no conocen normas básicas de conservación s y si bien se busca resguardarlas, se las somete a sistemas de guarda que producen un mayor deterioro de sus soportes". Además la mayoría de las colecciones carecen de descripción y documentación, datos que sólo pueden ser reconstruidos recurriendo a la memoria oral de los responsables de las instituciones. Además, "uno de los aspectos a considerar es que la formación de las colecciones en instituciones públicas, en su gran parte no ha derivado de políticas institucionales, sino que las mismas se conformaron a partir de donaciones por lo cual las fotografías reunidas no tienen criterio selectivo que les confiere una determinada unidad Y en ese sentido, la carencia de información sobre la procedencia de las colecciones" (Isler y Giordano: 2009 , 12-18)

127 La página puede visitarse en: https://www.facebook.com/aniversario.demercedes?fref=ts
} 
Respecto a lo que se pudo observar en estos lugares, por un lado, el Museo Histórico posee principalmente retratos de personalidades destacadas de la élite correntina cuyas autorías son atribuidas a los primeros fotógrafos que trabajaron en Corrientes entre el siglo XIX y XX: Alberto Ingimbert, Pedro Bernadet, Roberto Gersbasch, Hipólito Frittot, entre otros. En este contexto, resaltan a la vista del visitante los retratos de gobernadores de gran formato porque están en exhibición en la sala de conferencias "Historiador Dr. Valerio Bonastre", mientras otro fondo importante y organizado está constituido por álbumes fotográficos que, de ser requeridos son mostrados en sala de consulta. Entre ellos, nos resultaron de interés, por un lado, el Álbum Gráfico de la Provincia de Corrientes de 1913 encomendado al fotógrafo Alberto Ingimbert por el entonces gobernador Juan Ramón Vidal en el marco de las conmemoraciones del Centenario argentino y el cierre de gestión del primer mandatario; y, por el otro, el álbum denominado Ilustración de la Comisión del Centenario al pueblo de la Provincia de Corrientes, 1810-1910, editado también por el Taller de Artes Gráficas de Ingimbert en Corrientes, que posee imágenes conmemorativas del centenario, donde se destacan algunas fotos de procesiones religiosas en honor a la Virgen de la Merced, las pocas referentes a cultos religiosos halladas de principios de siglo XX sobre las que nos detenemos en el próximo apartado.

Por su parte, el Archivo General de la Provincia poseía hasta 2011, momento de nuestra primera visita, fotos sueltas sin ningún tipo de referencia y ordenación. Sin embargo, en agosto de 2012 se creó una fototeca con el fin de iniciar la identificación de las imágenes. Según comentaron los encargados del trabajo, la tarea resultó difícil por la falta de referencias en casi todas las copias. Las escasas fotos disponibles ingresaron a la institución por donaciones, son copias digitales en su mayoría y algunas copias papel que tienen como asunto vistas urbanas, edificios y personalidades y fueron producidas entre principios y fines del siglo XX. La primera clasificación realizada por el personal de la fototeca divide las imágenes en Personas y Lugares. Algunas están firmadas también por el fotógrafo Alberto Ingimbert. Aquí, dentro de las imágenes inventariadas, tampoco se identificaron imágenes con referencia de prácticas religiosas.

De los centros de documentación de la región donde encontramos igualmente escasas imágenes históricas con el tema de referencia pero con un acceso más directo de consulta por la disponibilidad de la base de datos digital, se encuentra el Núcleo de Estudios y Documentación de la Imagen (NEDIM) del Instituto de Investigaciones Geohistóricas CONICET/UNNE. Resultaron de relevancia en esta búsqueda las copias de la colección de Luis Priamo, que incluye la producción que el fotógrafo suizo Samuel Rimathé realizó a fines 
del siglo XIX en el Nordeste. Allí, entre vistas y tipos populares, se encuentra una imagen con referencia a la adoración de la Cruz de los Milagros, que de lo hallado podría tratarse de una de las fotografías más antiguas bajo resguardo de religiosidad correntina ${ }^{128}$. Este centro también dispone para la consulta copias de la Colección del Parque Nacional Mburucuyá, entre las que se cuentan imágenes de las décadas de 1940 y 1950 sobre la fiesta patronal de San Antonio de Padua en la localidad de Mburucuyá.

A nivel nacional, se consultó la Fototeca de la Biblioteca Nacional. La institución posee fotos de vistas urbanas relevantes tomadas por fotógrafos viajeros que visitaron Corrientes (Samuel Rimathé y los socios Benítez y Pagés por ejemplo), sin embargo, no posee fotos con referencia a la religiosidad correntina, al menos disponible para consulta en sala. Este fondo se conforma por unas 10.000 imágenes en negativos y copias, que se pueden consultar en su formato digital en sala y que se visitó en 2011 a los fines del relevamiento para esta investigación.

Por otra parte, resultó relevante el trabajo de búsqueda de imágenes en el Departamento de Documentación Fotográfica del Archivo General de la Nación, donde en relación a los espacios antes citados, fue posible identificar casi una veintena de imágenes sobre prácticas religiosas correntinas, todas referidas al culto católico capturadas entre principios y mediados del siglo XX y distribuidas en distintos sobres dentro de un par de cajas destinadas según la nominación a imágenes de la provincia de Corrientes. Algunas de las fotos encontradas son atribuidas a la autoría de Ingimbert y otras a donaciones colecciones particulares con autores no identificados.

Sobre la búsqueda en este último archivo, vale señalar que las imágenes del tópico religioso en sí, ya sea vinculado a festividades o ritos religiosos, están ausentes en los catálogos e inventarios temáticos. No obstante, imágenes con referencias cercanas aparecen en sobres nominados como Vistas de Corrientes, Monumentos históricos e Iglesias dentro de las cajas dedicadas a la provincia que sólo son posible advertir con una búsqueda detallada caja por caja, sobre por sobre, foto por foto. En nuestro caso, revisamos todo lo que hacía referencia en los inventarios a la provincia de Corrientes; sin embargo, ello no quita que puedan aparecer fotos de interés solapadas en otras clasificaciones dentro del acervo general.

Este escenario da cuenta, tal como observa Caggiano en su trabajo sobre las imágenes y las categorías del AGN, que si bien las clasificaciones intentan dar un tipo de orden a las imágenes y facilitan nuestra aproximación, tampoco ellas logran definirlas de una manera

${ }^{128}$ Una descripción de esta foto en particular en relación a colección de Rimathé puede leerse en Barrios (2011). 
integral; es decir, no siempre logran "contener la profusión del archivo" y esa superabundancia desestabiliza "las propias categorías de clasificación” (Caggiano, 2011). Ello hace evidente que sólo una búsqueda minuciosa foto por foto en cada uno de los centros citados nos posibilitaría dar cuenta de la existencia efectiva o no de las imágenes de interés, ya que los inventarios, en los casos que existe, no logran sujetar la polisemia de las orientaciones temáticas y genéricas; y tampoco consiguen frenar la movilidad de las fotos dentro de los acervos. Esta movilidad se pone de manifiesto en el caso de las fotos sueltas que pasan de sobre a sobre y se contaminan con otras nominaciones. Además, cabe señalar que esa búsqueda detenida, en muchas ocasiones es condicionada por los regímenes de acceso y disponibilidad de los materiales para la consulta.

Por lo tanto, sobre la base de estas limitantes se construyen las reflexiones que siguen focalizadas en las imágenes in-visibilizadas de principios del siglo XX tanto en los dos álbumes conmemorativos del Centenario editados por el Taller Bellas Artes de Alberto Ingimbert de la colección del Museo Histórico y en las cajas de fotos de la Provincia de Corrientes consultadas en el AGN. La selección responde a que estos acervos plantean nominaciones, sobres, cajas e inventarios de clasificación, posiciones de orden dentro del álbum y el archivo a partir de los cuáles pueden trazarse correlaciones con un contexto específico y trayectorias de autores también particulares -como la del fotógrafo Ingimbert-; posibilitando también describir funcionamientos de colección dentro de lo que Foucault llama un "sistema de discursividad" o un "principio de articulación" propio de una formación discursiva. Todas operaciones semiótico-discursivas que son difíciles de llevar a cabo en el caso de los corpus de imágenes sueltas.

\section{2.b) Las fotos de la religiosidad correntina admitidas entre las vistas del}

progreso

Alejandra Reyero, junto a Iturriza y Pelaza (2008), considera que la fotografía en tanto técnica -entre otras- al servicio del poder, constituye un medio a través del cual puede verse (hacerse visible) y paradójicamente invisibilizar (hacer invisible) la presencia de ciertos sujetos, objetos y representaciones sociales. En este sentido, la autora enfatiza que "de acuerdo a su propia modalidad de relacionarse con la realidad, la fotografía delimita el dominio no sólo de lo que se ve, sino también de lo que se puede ver, lo que se debe ver, e incluso lo que merece ser visto" (Reyero, 2008: 680).

A ello podríamos agregar que, en tanto instrumento al servicio del poder, lo que 
muestra y oculta la fotografía responde a regímenes de visibilidad y enunciación, siempre totalmente inmersos en las relaciones de poder que caracterizan a una época y que el dispositivo actualiza a partir de los usos y apropiaciones que de ellos hacen los sujetos ${ }^{129}$. Asimismo, esos regímenes, que instauran unas formas propias que privilegian la visibilización de ciertas prácticas y objetos, condicionan qué imágenes son posibles y relevantes de ser capturadas para un momento histórico particular; así como los modos de ser conservadas y mostradas también desde los dispositivos de ordenación/clasificación de la memoria como los álbumes y los archivos.

En lo que a nuestra investigación concierne, las fotos de temáticas relacionadas a prácticas religiosas correntinas -hoy abundantes en diversos medios y contextos- aparecen escasas en el mapeo de imágenes realizado sobre lo producido y difundido durante el siglo XIX y XX frente a aquellos múltiples retratos de las élites dirigentes y las vistas del "progreso" que signaron la época de la conformación del imaginario de la nación moderna.

De lo relevado pudimos observar que los autores más sobresalientes que forjaron el advenimiento de la fotografía en la provincia de Corrientes utilizaron la técnica para resguardar imágenes de familias destacadas, personajes ilustres de la política, el comercio y el arzobispado; y atestiguar la transformación de las ciudades, con casi todas las cámaras enfocadas en la capital provincial y las localidades que poseían explotaciones de puertos comerciales y de grandes campos productivos; es decir, lugares donde se reconocía el optimismo por el progreso.

Así, hacia fines del siglo XIX y buena parte del siglo XX, la atención de la mirada fotográfica estuvo centrada en el retrato y las vistas de paisaje urbano de la mano de profesionales que en su mayoría llegaron del exterior e instalaron sus estudios de fotografía en Corrientes. Según el historiador Federico Palma (1959), el romano Aristide Stephani, que vivió en la capital provincial desde 1846, fue el primer fotógrafo retratista de Corrientes; y entre una veintena de profesionales más, se destacaron en la emergencia de la fotografía correntina: Pedro Bernadet, Roberto Gersbach, Hipólito Frittot y Alberto Ingimbert. Imágenes de estos autores pueden verse de modo más condensado en el acervo del Museo Histórico de Corrientes, mientras algunas vistas y retratos se diseminan en otros archivos regionales y nacionales; y algunas postales todavía son comercializadas por filatelistas

\footnotetext{
${ }^{129} \mathrm{Al}$ respecto Agamben dirá que el dispositivo es "[...]un conjunto heterogéneo que incluye virtualmente cualquier cosa, lingüística y no lingüística al mismo título: discursos, instituciones, edificios, leyes [...]en sí mismo es la red que se establece entre estos elementos [...] tiene siempre una función estratégica concreta y se inscribe siempre en una relación de poder [...] resulta de la intersección de las relaciones de poder y de relaciones de saber" (Agamben, 2011: 249).
} 
porteños.

De los años de actuación de estos fotógrafos, es posible observar que el retrato y las vistas urbanas fueron los dos grandes géneros que dominaron el campo visual de lo memorable pero siempre orientados a enaltecer el proyecto modernizador y colonizador promovido por la clase "culta" o la clase media emergente. Esto hizo que las esporádicas capturas relacionadas a las clases populares y sus prácticas no fueran consideradas "dignas" de ser mostradas y de ellas casi no se guardan registros, entre las que podríamos ubicar a las fiestas populares. Por ello, como veremos más adelante, de las prácticas religiosas, sólo algunas escenas del culto oficial fueron consideradas dignas de ser recordadas.

La concepción de época sobre lo digno y lo indigno de fotografiar y resguardar, que claramente se ve atravesada por concepciones de clase, se explicita en un párrafo del texto que le dedicó Palma a la historia de la fotografía correntina:

[...] La fotografía correntina anduvo desde sus primeros años por el camino de la recatada decencia que le señalaron el daguerrotipo y la fotografía papel, pero desde 1870 comenzó a tornarse chabacana al lograr amplios sectores de la población llegar hasta los talleres fotográficos merced a los precios más reducidos. La guerra con el Paraguay había enfrentado al hombre de pueblo con situaciones no presentidas que le dieron su propia tónica. De ahí la pose quebrada y los grupos confundidos en abrazos y apretones de manos que transpiraban falsa cordialidad, donde las guitarras, las botellas, o el caballo pretendían dar una nota de criollismo, logrando en cambio proporcionar la imagen cabal del compadrito de aquellos años. Sólo la clase culta mantuvo el adecentamiento en la perpetuación de la imagen mediante la fotografía (Palma, 1959: 33).

Los conceptos vertidos por Palma confirman la hipótesis de Isler y Giordano cuando aseguran que "una sociedad de tipo tradicional" como la correntina y, además "con una fuerte impronta de la cultura de elites ha marcado una trayectoria de la imagen a conservar vinculada a los estamentos de poder social, económico y político" (Isler y Giordano, 2009). Al mismo tiempo, el comentario de Palma acerca de la emergencia de la imagen del "compadrito"130 que empieza a aparecer en la fotografía de fines de siglo XIX, como intentando "fisurar" las representaciones "decentes" de la cultura local dominantes, habla del inicio de una serie de transformaciones en torno a la concepción de la fotografía regional en general.

Como señala Gabriela Quiñonez (2011), el episodio de la Guerra de la Triple Alianza (1865-1870), que introduce la fotografía de guerra en Sudamérica, a su vez marca los

\footnotetext{
${ }^{130}$ El compadrito viene a designar al arrabalero de los tangos porteños, específicamente caracterizados en la danza y en la forma de andar por la postura del cuerpo afectada, los cortes y quebradas; pero también en la lectura de Palma se extiende a la actitud e imagen de los sectores de baja condición social en general que empiezan a poblar la fotografía correntina de fines de siglo XIX y principios del XX.
} 
caminos de la "popularización" de la misma. Es decir, desde entonces ya no estará restringida al retrato en estudio de los hombres y mujeres de los sectores sociales más elevados sino también de personajes, escenas y paisajes urbanos y rurales. Las "nuevas" imágenes fueron nutridas también por los avances tecnológicos que posibilitaron cámaras más livianas para trabajar fuera del estudio y el crecimiento de la fotografía de viajeros, interesados en capturar vistas urbanas y rurales incluidos "tipos sociales"131, así como el crecimiento de la fotografía comercial local y el ingreso a escena del fotoperiodismo nacional focalizado en los acontecimientos de relevancia noticiosa con corresponsales en el interior.

No obstante ello, es difícil encontrar en los archivos fotográficos oficiales de documentación fotográfica de los siglos pasados -sobre todo provinciales- las escenas populares teñidas de "criollismo" que aparecen en el relato de Palma, a excepción de los casos referidos a la Guerra de la Triple Alianza, donde las poblaciones indígenas y criollas, cobraron protagonismo como soldados, entre ellos los gauchos ${ }^{132}$. Dichas fotografías visibilizan a estos hombres vinculados a actividades cotidianas (como tomar mate, tocar la guitarra, etc) en el marco de las tiendas en los campos de batalla ${ }^{133}$. También hay algunas referencias a actividades cotidianas de los sectores populares en las imágenes de las campañas evangelizadoras que los sacerdotes se ocuparon de registrar hasta entrado el siglo XX, entre alguna que otra imagen "tipos sociales" de fotógrafos viajeros ${ }^{134}$.

En el caso que hayan existido más fotografías de fines de siglo XIX y principios del XX que pudieran remitir a peñas, payadas o bailes populares (aquí aludiendo a la imagen de las guitarras, botellas, caballos que refiere Palma, en su tono despectivo) o de fiestas

\footnotetext{
${ }^{131}$ Fue un género muy desarrollado por los fotógrafos viajeros. Sobre Corrientes se destacan algunos trabajos del suizo Samuel Rimathé en el siglo XIX. Si bien Rimathé fue considerado uno de los pioneros de la fotografía social en el país por captar en sus imágenes además de la vibración de la nueva ciudad, la marginalidad y la pobreza del interior; el fotógrafo también incluyó tomas de familias de indígenas, criollos, gauchos y otras subclasificaciones por oficios que se publicaron en las principales revistas ilustradas del país como producto de una óptica costumbrista. Estas caracterizaciones suponen una continuación del género literario en la Edad Moderna que se constituyeron en base a la físiología, que obtuvo bastante auge en los siglos XVIII y XIX (Giordano, 2008; Barrios 2011; Cuvardic García, 2009).

${ }^{132}$ Cabe señalar que la mayoría de estos hombres fueron reclutados a la fuerza. En relación a los gauchos específicamente, según indica Pablo Alabarces (2001), ellos constituyeron la principal fuerza de los caudillos federales que combatían en las luchas civiles internas contra unitarios, quienes finalmente lograron vencer hacia 1880 imponiendo la organización centralizada en Buenos Aires en torno al modelo agroexportador y librecambista. Alabarces argumenta que con el triunfo de la política de los unitarios y sobre todo la imposición de un nuevo sistema económico desaparece en la escena nacional la figura del gaucho como "sujeto político, económico y cultural" ya que se ve obligado a abandonar su nomadismo y anarquía y someterse a la explotación intensiva de la producción agropecuaria. En esa época de batallas, y vinculados a tanto a alguna posible actuación en la Guerra de la Triple Alianza como junto los federales colorados, se construye la leyenda del Gaucho Gil, según los textos de Félix Coluccio (1995).

${ }^{133}$ Un relevante trabajo sobre las fotografías de la Guerra de la Triple Alianza puede leerse en Miguel Cuarterolo (2000).

${ }^{134}$ Algunas referencias e imágenes pueden verse y leerse en los textos de Mariana Giordano (2004 ); Luis Priamo (2007), entre otros.
} 
religiosas populares correntinas (estas eran de nuestro interés al indagar en los archivos y no han sido halladas), se podría establecer allí un difracción entre lo digno de fotografiar para alguien en ese momento y lo digno de conservar para recordar desde los acervos oficiales estatales. Decimos esto, porque en el marco de los archivos provinciales visitados, se observa una predilección por resguardar aquellas imágenes que sirvieron como instrumento de legitimación de los procesos y personajes que sostuvieron el orden social conservador y antipopular dominante de aquella época.

En el marco de transformaciones de la concepción de la fotografía correntina de fines de siglo XIX y principios del siglo XX y los usos dados por determinados sectores sociales, resulta particularmente relevante en relación a los intereses de esta tesis la obra de Alberto Ingimbert. Este fotógrafo de origen francés, tras un paso por la localidad correntina de Goya, a principios del siglo XX estableció su estudio de fotografía comercial Las Bellas Artes en la ciudad de Corrientes. Realizó retratos sociales, editó álbumes y postales y fue considerado uno de los profesionales de la fotografía más integrales que se instaló en la provincia, tanto por la calidad técnica como artística de sus trabajos. También realizó muchas producciones por encargo de la dirigencia política y eclesiástica local, entre las que se hallan algunas imágenes vinculadas a festividades religiosas, y además cobró notoriedad como corresponsal de la revista Caras y Caretas (Palma, 1959; Giordano y Méndez, 2003).

Producto de los trabajos realizados por Ingimbert en el taller Las Bellas Artes surgieron el álbum Ilustración de la Comisión del Centenario al pueblo de la Provincia de Corrientes, 1810-1910, y el Álbum Gráfico de la Provincia de Corrientes de 1913 que plantean un relato bastante homogéneo de Corrientes como ciudad "moderna" y "progresista". Se trata de una imagen que la élite social y política local buscaba proyectar a nivel nacional en el marco de las conmemoraciones del Centenario de la nación. Por la configuración de este imaginario modernocéntrico que claramente requirió de un correlato visual para difundirse junto a otros textos y porque Ingimbert fue corresponsal de la difundida revista Caras $y$ Caretas, que ocupaba un rol relevante en el debate socio-político nacional, no resulta raro que la mayoría de las imágenes de cultos religiosos hallados en distintos espacios, como el propio Departamento de Documentos Fotográficos del Archivo General de la Nación (AGN) estén adjudicadas a este autor.

Cabe recordar que dicho Departamento dentro AGN se conformó con las colecciones provenientes de estudios cuyas producciones respondieron al modelo progresista y a los 
intereses de los grupos dominantes de la época, entre ellas las del estudio Witcomb ${ }^{135}$, a cargo de la fotografía oficial de los presidentes hasta 1970, a las que luego se sumaron justamente los archivos de Caras y Caretas, además de los diarios Noticias Gráficas, Crítica, de la Agencia Alerta y de la Sociedad Argentina de Fotógrafos Aficionados ${ }^{136}$.

Volviendo a los álbumes del Centenario, de lo indagado podemos señalar que en el álbum Ilustración de la Comisión del Centenario de 1910, Ingimbert inicia, a partir de 30 fototipias articuladas con breves epígrafes y sin prólogo, un retrato de la ciudad de Corrientes moderna, progresista y pujante que en el Álbum Gráfico de 1913 se profundiza con un mayor componente del discurso político local estrechamente ligado a la figura y los intereses del gobernador Juan Ramón Vidal.

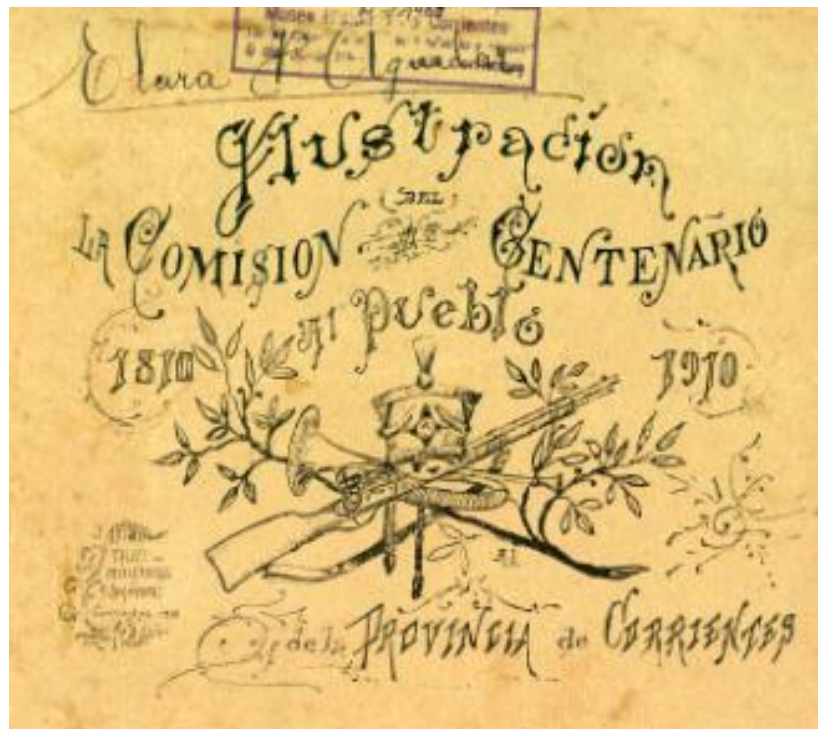

Tapa del Álbum Ilustración de la Comisión del Centenario al pueblo de la Provincia de Corrientes, 1810-1910. Taller Artes Gráficas de Alberto Ingimbert. Col. Museo Histórico.

En el conjunto del álbum de 1910, entre retratos grupales de personajes de la élite local que incluyen a los integrantes de la Comisión del Centenario y de la Sociedad Española y los registros de actividades sociales y cívico-militares, se encuentran tres imágenes de una misa de campaña realizada en honor a la Virgen de La Merced, la patrona de Corrientes. La elección de las imágenes vinculadas a esta virgen y no aquellas que pudieran referir a otros santos, vírgenes o prácticas devocionales de la ciudad o de la provincia para integrar el álbum

\footnotetext{
135 La Colección Witcomb en el Archivo General de la Nación está conformada por alrededor de 300.000 negativos fotográficos sobre placas de vidrio que pertenecieron a la Galería Witcomb.

${ }^{136}$ Cfr. Caggiano en Giordano y Reyero (2011). La cantidad de documentos fotográficos abierta a la consulta en el archivo es de aproximadamente 800.000 de piezas, pertenecientes a diversas colecciones. Más información en la página web del archivo.
} 
pudo haberse debido a que el culto a esta virgen era por entonces el más propagado en la alta sociedad correntina ${ }^{137}$. También pudo tener que ver con que Ingimbert fue uno de los profesionales más requeridos por los sacerdotes franciscanos a cargo del convento de La Merced para obtener fotografías relacionadas con la misión evangelizadora-civilizadora que llevaban adelante desde mediados del siglo XIX y hasta mediados del siglo XX en la región; imágenes que luego eran difundidas en textos y postales y en el marco de esos encargos Ingimbert guardaba estrecha relación con el grupo eclesiástico de dicho convento ${ }^{138}$

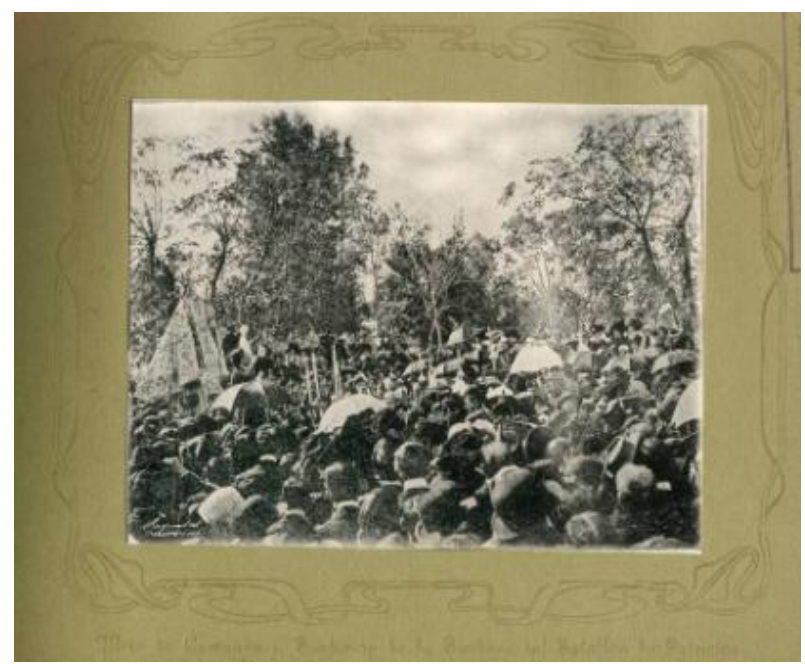

Alberto Ingimbert. Procesión de la Virgen de las Mercedes para la Misa de Campaña. 1910. Álbum Ilustración de la Comisión del Centenario al pueblo de la Provincia de Corrientes, 1810-1910. Taller Artes Gráficas de Alberto Ingimbert. Col. Museo Histórico.

137 En De Buenos Aires a Iguazú. Crónicas de un viaje periodístico a Corrientes y Misiones, editado en 1901, Manuel Bernárdez señala que la iglesia de la Merced era la "iglesia de moda para la alta sociedad correntina, a pesar de ser más bien una dependencia del convento de mercedarios" (Bernárdez, 1901: 25). Varios fueron los eventos que estrecharon las relaciones de la élite correntina con esa iglesia. Entre ellos, cabe recordar que la figura de la Virgen de la Merced se liga el regreso con vida a la ciudad de cuatro de las cinco "cautivas correntinas", todas damas destacadas de la sociedad correntina (hijas y esposas de familias tradicionales de la élite y con importantes posiciones de poder) que fueron llevadas a cautiverio en represalia por la conducta de sus esposos, quienes respondían a Mitre en la época de la guerra de la Triple Alianza. Relata la historia que ellas habían prometido a la virgen caminar hasta la iglesia a agradecer, incluso antes de saludar a sus familiares, si se les concedía el milagro de volver y así lo hicieron. Hoy descansan en este convento sus restos.

${ }^{138}$ Según Mariana Giordano, tras la expulsión de los jesuitas, a mediados del siglo XIX, luego de la organización constitucional, a partir de 1854, fueron los sacerdotes franciscanos de Propaganda Fide que desde el Convento de La Merced crearon misiones en distintos puntos del territorio provincial aún habitada por aborígenes para comandar la denominada Campaña de pacificación (Giordano, 2004: 517-550). Giordano y Méndez, agregan que la tarea "evangelizadora y civilizadora" se extendió hasta mediados del siglo XX y hay documentos escritos y fotográficos de la Orden que así lo acreditan. En este marco, según las investigadoras, el vínculo más fuerte Ingimbert lo tuvo con el padre Fray Buenaventura Giuliani, aficionado a la fotografía "con quien cooperaba mejorando o duplicando las imágenes que éste tomaba para acreditar su labor misional". Asimismo, comentan "este fotógrafo realizó retratos de varios de los frailes en su estudio, cuando éstos se trasladaban a la capital correntina" y también se le encomendó imágenes de las misiones en Chaco y Formosa (Giordano y Méndez, 2003). 
En definitiva, más allá de los factores e intereses que precedieron la captura y el resguardo de las fotografías en general, las fotografías de la misa de campaña de este álbum son las pocas que se conservan vinculadas a cultos religiosos en los archivos oficiales estatales de la época del centenario. Ellas se suman a tomas de la Coronación Pontificia de la Virgen de Itatí, que hacia 1900 significó un evento de trascendencia nacional por la gran movilización de personas de toda la provincia a la Iglesia de la Cruz de los Milagros, donde se desarrollaron los actos en la ciudad capital. Copias de imágenes de este evento, capturadas por Ingimbert se guardan en diversos archivos como el AGN y circularon en documentos, revistas eclesiásticas y aún hoy se actualizan en la prensa en el marco de conmemoraciones de la "vida" de la iglesia católica correntina. También del autor en el archivo nacional se resguardan capturas fechadas en el año 1907 sobre la festividad conmemoración de la Cruz de los Milagros. Esta festividad y la de la Virgen de Itatí se han construido desde el discurso eclesiástico y mediático como las “dos grandes devociones correntinas” ${ }^{139}$.

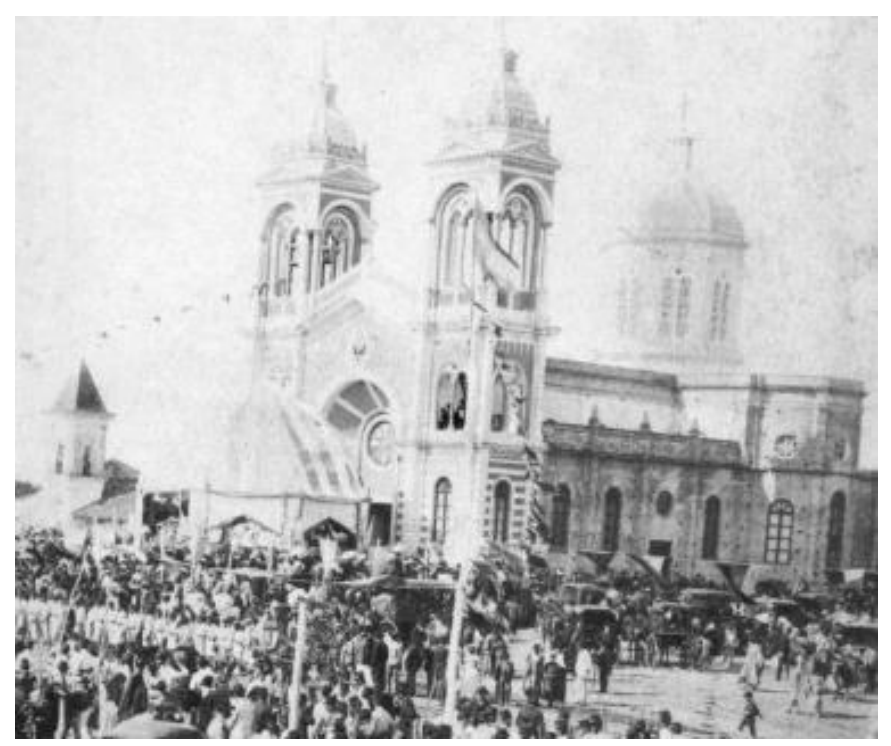

Alberto Ingimbert. La coronación de la Virgen de Itatí en la iglesia de la Cruz, ca. 1900. Col. Archivo General de la Nación.

\footnotetext{
139 La Cruz de los Milagros y La Virgen de Itatí configuran dos piezas claves en torno a las cuales la Iglesia y la clase dirigente construyó, incluso desde época de la colonia, los mitos fundacionales de la correntinidad católica, creyente y tradicional. Por un lado, la cruz fundacional de la ciudad de Corrientes es el enclave de la conquista española en torno al cual se tejió la leyenda de un milagro que habría logrado automáticamente la sumisión y conversión de los indios guaraníes al cristianismo. Otra serie de milagros se ligan a la imagen de la virgen "aparecida" entre las piedras a la vera de la localidad de Itatí también habitada por guaraníes. En relación a ello el discurso eclesiástico reivindica hasta la actualidad la "cohesión" de dos culturas (la guaraní y la hispánica) como producto de los "milagros" y es el relato dominante que puso a recircular en el propio libro del Centenario de la Iglesia de Corrientes de 2010, editado por el Arzobispado, y reproducen diferentes publicaciones de diarios provinciales, con la recirculación de las fotos de Ingimbert. Ver más Barrios (2011).
} 


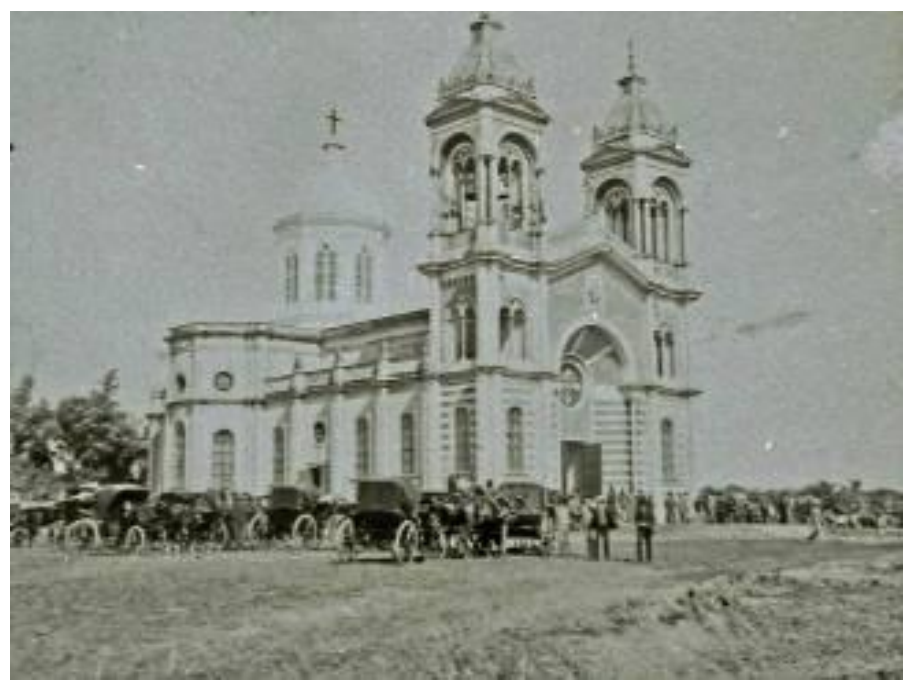

Alberto Ingimbert. La conmemoración al templo de la Cruz del Milagro, ca. 1907. Col. Archivo General de la Nación.

Por otra parte, el Álbum Gráfico de la Provincia de Corrientes de 1913 fue encargado por gobernador autonomista Juan Ramón Vidal que llegaba por en ese año al fin de su segundo mandato iniciado en 1909. Casi como corolario de gestión, este álbum se centró en visibilizar la transformación urbana de la ciudad capital y colaborar visualmente con la difusión del discurso político del progreso que promovía el primer mandatario provincial, en consonancia con el imaginario de la nación moderna y progresista que se construía en el país en el marco del centenario de la revolución de 1810. A diferencia del conjunto anterior, este álbum posee una introducción escrita por Blasco Ibáñez que lleva por título "Un hombre y un pueblo". El discurso, con una clara orientación ideológica a favor de la figura del gobernador, hace referencia al liderazgo de Vidal y su visión del progreso que pueden ser traducidas en las imágenes de la ciudad que presenta el compendio.

En este sentido, las fotografías se focalizan en visibilizar los grandes monumentos edilicios, palacios gubernamentales, iglesias, plazas, paseos y el trazado urbano que dan cuenta de la modernización de la ciudad; además de la actividad comercial del área portuaria. La visión de Ingimbert plantea, como señala Quiñonez, un "paisaje urbano sin periferia" (Quiñonez, 2011: 172). Este paisaje deja de lado su pasado colonial de casas de galerías para mostrar la opulencia nuevos edificios de estilos arquitectónicos vinculados al "neorrenacimiento italiano, el academicismo francés y repertorios eclécticos" que pueblan el centro urbano (Giordano y Romero, en Quiñonez, 2011: 172). Además, ese centro se construyó como el punto neurálgico político y social, teniendo como epicentro la plaza 25 de Mayo con los edificios gubernamentales a su alrededor (y también donde se ubica el 
Convento de La Merced, iglesia de moda de la alta sociedad por el 1900 según Bernárdez, 1901, aunque en la toma no aparece pues desde la torre de la iglesia se capturaba la panorámica de la plaza) como puede observarse en el compendio de 7 vistas de una de las páginas del álbum.

Este relato invisibiliza las zonas no urbanizadas de los barrios suburbanos e incluso las localidades del interior provincial, así como también las prácticas y costumbres de los sectores populares. También hay un esmero por mostrar el progreso económico y dejar atrás "los fracasos de distintos cultivos industriales que se ensayaron en la provincia durante las décadas precedentes" (Schaller, en Quiñonez, 2011: 175).

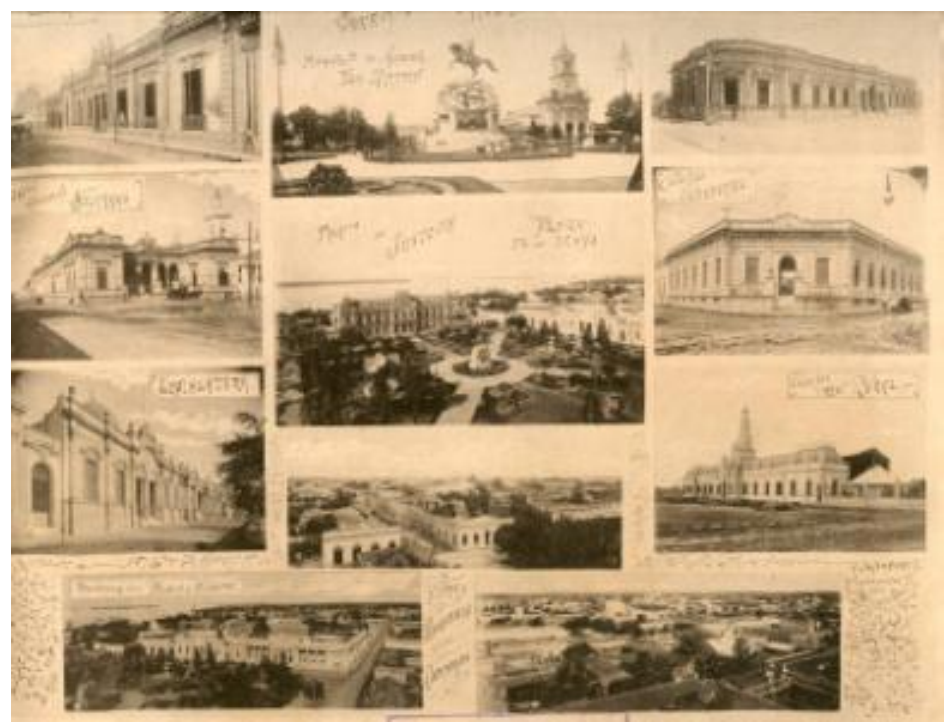

Alberto Ingimbert. Vistas de infraestructura y zona portuaria. Álbum Gráfico de la Provincia de Corrientes. 1913. Col. Museo Histórico

Algo curioso en este álbum de 1913, a diferencia del compendio de 1910, es que no aparecen imágenes de cultos religiosos. Esta "ausencia” pudo deberse a que el gobierno de Vidal adscribía a una fuerte orientación liberal que se caracterizó por defender los derechos individuales, la propiedad privada y también la libertad de cultos, promoviendo la separación del estado de la iglesia. Incluso es relevante remarcar que durante este segundo mandato, que encuentra su narrativa gráfica-visual en este álbum, Vidal logró la reforma de la Constitución provincial donde, según narra Solís Carnicer, no sólo se defienden los lineamientos del progreso sino también se "derogó la exigencia de pertenecer a la religión Católica Apostólica Romana para ser elegido gobernador y modificó la fórmula de juramento del gobernador que ahora debía hacerlo 'por Dios y por la patria', y no por 'Nuestro Señor y los Santos Evangelios, tal como se venía haciendo desde 1864" (Solís Carnicer, 2004: 60). Todo esto a 
pesar que la sociedad correntina siempre se caracterizó por plantearse fervientemente creyente e identificada, desde los sectores sociales elevados y medios emergentes, casi excluyentemente como católica, sobre todo en esta época referenciada.

En ese marco, las mujeres aparecían con un rol fundamental en la modelación de los principios y valores cristianos como elementos cohesionadores de la familia al interior del hogar, y también por extensión en la sociedad traducida en las acciones de beneficencia. Por ello, no es de extrañar que paradojalmente a su adscripción liberal, el propio Vidal (como sucedía en el caso de otros dirigentes y hombres importantes de la élite correntina, en buena parte incluso fueron miembros de ordenes masónicas) era hijo y esposo de dos "damas distinguidas de la sociedad correntina" y "fervientemente" católicas, según historiza Solís Carnicer, que se dedicaron a actividades sociales y de beneficencia; acciones muy emparentadas con las de algunas comisiones de mujeres que sí se visibilizan en el álbum de 1910.

De este modo, observamos que las imágenes de Ingimbert como instrumentos al servicio del poder, como señalan Giordano y Romero (2003), vienen a otorgarle un relato visual a un discurso político gubernamental centrado en el progreso que tiene como centro la figura de Vidal ${ }^{140}$. En su análisis del discurso del gobernador, Solís Carnicer señala que uno de los aspectos que más han destacado desde el entorno de este caudillo es "el hombre que hace cosas". Asimismo, comenta que cuando Vidal llega a su segundo mandato "es presentado como el gobernante que es capaz de enfrentarse a todas las dificultades con tal de brindar a Corrientes las obras de progreso tanto material, institucional como moral que la provincia reclamaba" (Solís Carnicer, 2004:159).

Asimismo, la reflexión sobre ambos álbumes del Centenario nos permiten observar que sobresalen los retratos de personalidades ilustres, mandatarios, sectores sociales conservadores más acomodados y vistas urbanas de una ciudad modernizada; mientras que no se visibilizan fotos de prácticas religiosas populares, salvando las pocas editadas por Ingimbert todas ellas vinculadas al culto católico y específicamente a figuras religiosas propagadas en el entorno de la "alta sociedad".

En resumen, estos relatos visuales plantean una orientación ideológica centrada en validación de jerarquías sociales y proyectos políticos gobernantes; específicamente en los casos analizados ligados al conservadurismo provincial y también nacional que estaba representada en la figura de Vidal, dirigente que formó parte de la "generación del 80" y es

\footnotetext{
${ }^{140}$ Un análisis detallado del álbum puede leerse también en el escrito de Giordano y Romero (2003).
} 
sindicado como un ferviente opositor al gobierno de Hipólito Yrigoyen, formando parte como senador nacional en 1930 del grupo que expulsó del gobierno al radical para entronizar a la primera dictadura militar argentina.

Algo similar ocurre en el ámbito de la visita al Departamento de Documentos Fotográficos del AGN, donde el intento caracterización de las fotos que refieren a prácticas de religiosidad correntinas halladas nos remiten directamente a un principio de clasificación, ordenamiento, mostración y ocultamiento que responden a los regímenes de visibilidad establecidos en años de 1930 momento de conformación el archivo. Este tiempo habla a su vez, de una formación discursiva atravesada por los intereses de los sectores dominantes en consolidar la conformación de la nación moderna, conservadora y perennizar memorias e identidades unitarias.

En ese marco, una escasa veintena de imágenes referentes a la religiosidad correntina, todas del culto católico aparecen en cajas correspondientes a la provincia de Corrientes, en medio de un archivo, que como bien describe Caggiano (2011), plantea una sobreabundancia de imágenes de presidentes y personalidades, vistas urbanas; así como también escenas de costumbres y tipos populares. Estas categorizaciones temáticas aportaron a la construcción de estereotipos identitarios nacionales, entre ellos Aborígenes, Negros y Gauchos ${ }^{141}$ (tres grandes temas en la clasificación del archivo), cuya reproducción en serie a través de fotos postales y sellos-postales signó el interés y el desarrollo comercial de la fotografía a principios del siglo XX.

La mayoría de las imágenes de prácticas religiosas correntinas, leídas en el conjunto con los registros de edificios, monumentos a próceres, iglesias, vistas y retratos, que se asoman dentro de las cajas de la provincia, tienden a construir la visión de una Corrientes heroica, culta, clerical, católica y tradicional.

Observadas desde su individualidad, entre esta veintena, todas las imágenes referencian los cultos a la Virgen de Itatí, La Merced y la Cruz de los Milagros. Además de las fotos de autoría de Ingimbert a las que ya referimos (todas de principios del siglo XX), aparecen muchas de autores no identificados que llegan a referenciar prácticas religiosas hasta la década del sesenta. En términos generales, se trata de imágenes que hacen foco en los

\footnotetext{
${ }^{141}$ Al respecto señala Caggiano (2011) que la clasificación del archivo ha sido heredada de 1930. "En esta época, 'aborígenes', 'negros' y 'gauchos' representaban tres figuras centrales en los discursos intelectuales, literarios y políticos dominantes acerca de la configuración de la nación Argentina”. Por su parte, Carlos Massota, antropólogo que estudió las antiguas tarjetas postales fotográficas que circularon por el correo argentino entre 1900 y la Primera Guerra Mundial, señaló en una entrevista difundida en Clarín en 2008 que "Las postales de indios se inscriben en el universo de las postales etnográficas o exóticas, elaboran un estereotipo inmerso en una naturaleza indómita, alejada del contacto cultural y la modernidad. Así dispuesto, el indio viene a compartir el escenario de 'lo nacional' con el gaucho, como su opuesto".
} 
altares, los sacerdotes en misa, o panorámicas donde, al igual que en las fotos de Ingimbert, se refuerza la idea de crecimiento de la fe expresada en el emerger de la masividad de fieles (principios y mediados del siglo $\mathrm{XX}$ ) en torno a las iglesias, los santos y las vírgenes católicas.

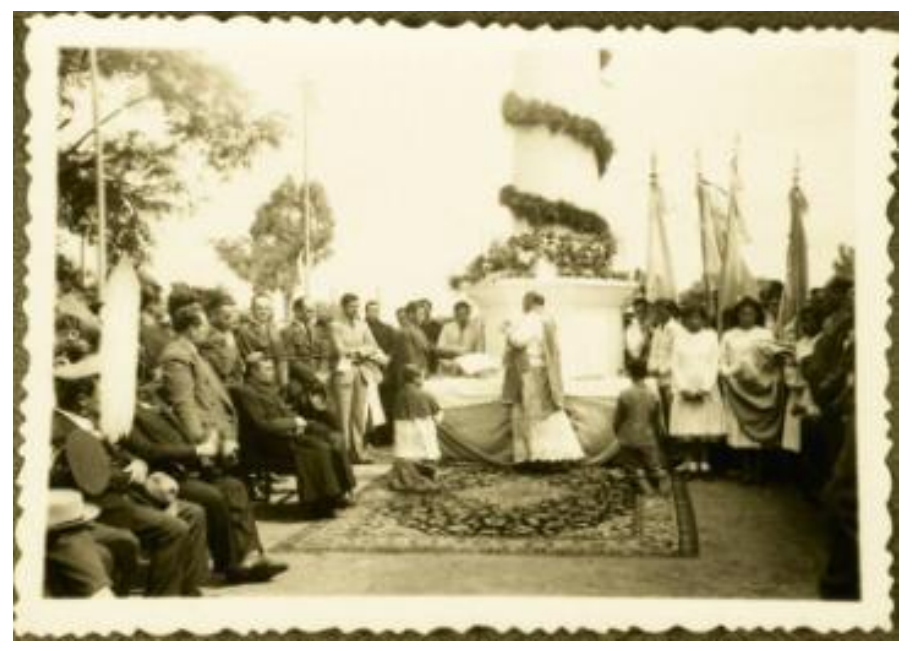

Autor no identificado. Misa de la columna histórica de la Av. 3 de Abril en el 350 Aniversario de la ciudad. 14 de Abril de 1938. Col. AGN.

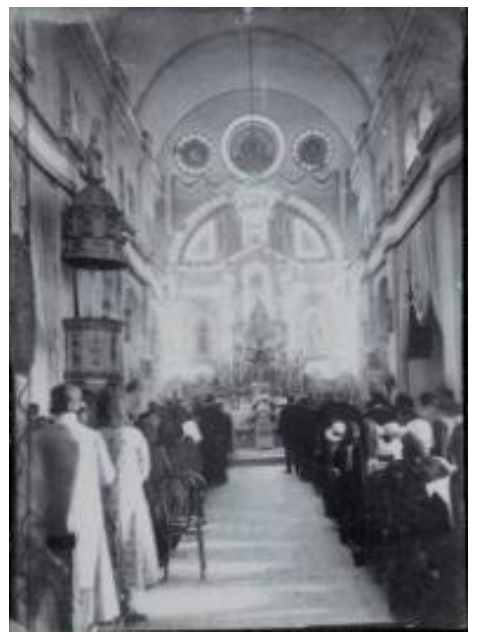

Autor no identificado. Fiesta de Nuestra Señora de las Mercedes. Octubre, 1926. Col. AGN. 

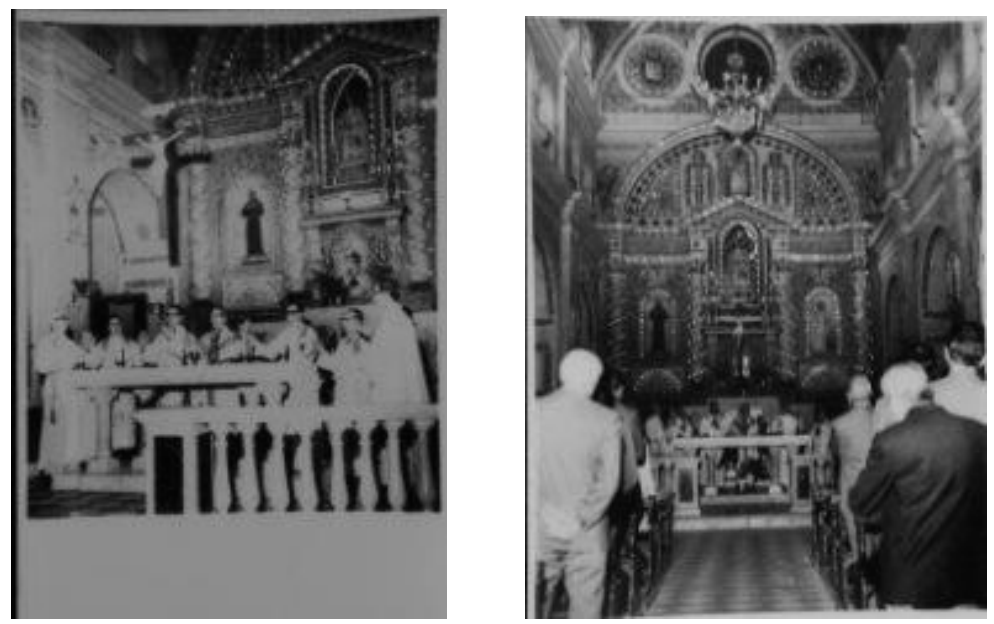

Autor no identificado. Misa Iglesia de la Merced. Ciudad de Corrientes. Octubre de 1969. Col. AGN.

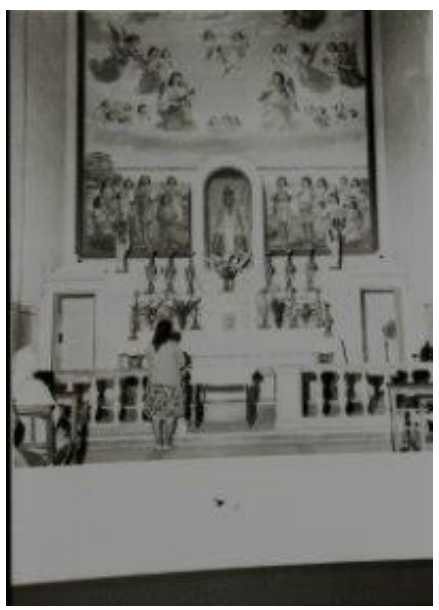

Autor no identificado. Camarín de la Virgen de Itatí (Patrona del Litoral argentino). Basílica de la Virgen de Itatí. Corrientes. Octubre, 1969. Col. AGN.

Salvo una imagen de las feria comercial alrededor de la Basílica de Itatí, las otras fotografías encontradas no registran los entornos, el espíritu lúdico, informal y las acciones espontáneas en las celebraciones y mucho menos hay rastros de las actividades heredadas de los pueblos indígenas que ya desde esa época planteaban una presencia paralela o sincretizada a las prácticas devocionales oficiales ${ }^{142}$.

\footnotetext{
${ }^{142}$ En los archivos provinciales, constituyen una excepción las imágenes de las peregrinaciones a caballo y en carreta protagonizada por los sectores populares hacia la Basílica de Itati que desde 1910 se empezaron a publicar en algunos diarios, especialmente en El Mensajero de la Virgen de Itatí, revista del santuario de gran difusión entre suscriptores católicos de casi todos los poblados de la provincia de Corrientes (incluso los más pequeños). Estas publicaciones sirvieron, aún lo hacen porque la revista sigue publicándose, para enfatizar el discurso eclesiástico que construyó a la devoción por esta virgen como el punto de "cohesión" de la cultura guaraní y la española y también como la articuladora de la fe de todas las clases sociales
} 


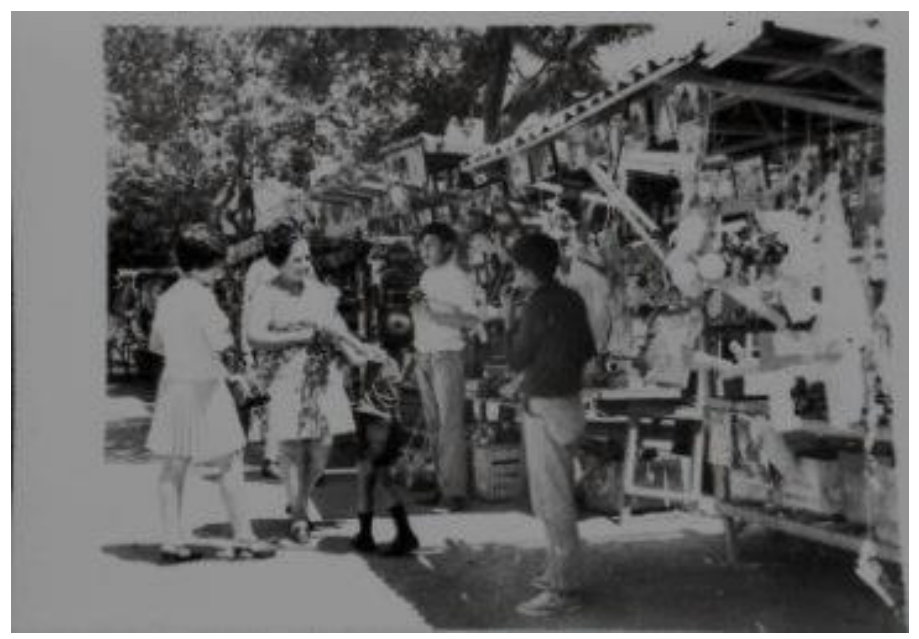

Autor no identificado. Feria en Itatí cerca de la Basílica de Itatí. Corrientes. Octubre, 1969. Col. AGN.

Al parecer esta escasa veintena de imágenes que difunde el imaginario de una provincia creyente, católica y clerical es la única que de alguna u otra manera fue acercada y admitida para ser conservadas en el acervo general de la Nación. Fotografías de un tópico, que al consultar el índice general o los títulos de las cajas y sobres aparecen literalmente ausentes, pero que al buscar entre el "orden y el desorden de las clasificaciones" -como indica Caggiano-, aparecen en al menos tres cajas, a su vez guardadas dentro de siete sobres diferentes. Denominadas como tales, las fotografías de prácticas o ritos religiosos no sobresalen en éste archivo ni en otros que resguarden fotos de principios del siglo pasado.

Por otra parte, la escasez de imágenes de prácticas religiosas a principios del siglo XX se habría debido en principio a que entonces la Iglesia no permitía tomar fotografías dentro de los templos o en el momento de mayor concentración espiritual de los fieles porque consideraba que alteraba los rituales, prohibición que se fue modificando con el paso del tiempo. Y, en segundo lugar, porque fotografías sobre esta temática no eran redituables para su comercialización e intercambio a través de las foto postales por ejemplo, hasta que surgió la necesidad de contar con ellas para su difusión en los folletines pastorales o en la prensa.

También, cabe señalar que la emergencia de dichas formas gráficas de la industria cultural en los primeros años del siglo $\mathrm{XX}$ se ven favorecidas por la modernización tecnológica argentina; sin embargo las imágenes y sus formas de organización analizados hasta aquí -desde los álbumes del centenario y el archivo- forman parte de una "economía visual"143 que precede el advenimiento de la constitución de la cultura de masas en el país. Es

\footnotetext{
${ }^{143}$ El concepto de economía visual es utilizado por Débora Poole para pensar en las imágenes visuales como parte de una comprensión integral de las personas, las ideas y los objetos. Dice la autora que "en un
} 
decir, ese régimen de visión remite a formación discursiva atravesada por los modos de producción/valoración de imágenes de los años 1900-1930 donde se impone la construcción de un nacionalismo de elites, más allá que en el conjunto del AGN se adviertan hacia fines de la década de 1960 nuevas incorporaciones que podrían asociarse algunas mínimas variantes de sentido.

En ese sentido, resulta relevante indicar que la cultura de masas argentina, que en los primeros años del siglo XX fue predominantemente gráfica, justamente a partir de 1930 experimenta una nueva expansión con la proliferación de los relatos radiales, cinematográficos y más tarde los televisivos. Sobre todo el cine y la televisión cambiarán enfáticamente las formas de producción, circulación, consumo y percepción de las imágenes hacia mediados de la centuria, dando lugar a la emergencia de nuevo régimen de visibilidad. Las condiciones e implicancias de esta transformación en la configuración del "mundo de imágenes del Gaucho Gil” indagaremos el apartado siguiente.

\section{Visibilización de lo popular en tiempos de la cultura massmediática y digital}

Lo analizado en los apartados anteriores pone de manifiesto cómo las imágenes que formaron parte activa del discurso del progreso y la modernización -proyecto que dominó el campo referencial de la fotografía y otros textos de fines de siglo XIX y principios del XXemergieron como formas estratégicas de respuesta a las necesidades de reconocimiento, legitimación y sostenimiento de un orden socio-político específico.

Entre los "retratos" del progreso y la ciudad moderna que promovió la élite social y política dirigente correntina desde el inicio de los festejos del Centenario argentino y parte del transcurso del siglo XX fueron escasas las imágenes de prácticas religiosas consideradas social, cultural, estética y políticamente valiosas para ser fotografiadas y conservadas. En las pocas tomas resguardadas predomina la concepción de Corrientes como una provincia católica, clerical, creyente y tradicional. Dichas capturas, en la mayoría de los casos, se realizaron desde una perspectiva de corte costumbrista respondiendo a principios estilísticos documentales, descriptivos, contemplativos, estáticos ${ }^{144}$ de misas y procesiones católicas.

La información recabada en los archivos de diarios, las diferentes materialidades relevadas en el seno de la propia festividad del Gaucho Gil, las conversaciones mantenidas en

sentido general, la palabra economía sugiere que el campo de la visión está organizado en una forma sistemática. También sugiere claramente que esta organización tiene mucho que hacer con relaciones sociales, desigualdad y poder, así como con significados y comunidad compartida" (Poole, 2000: 5).

${ }^{144}$ El estatismo también está influido por la tecnología fotográfica con la que se operaba en la época. 
el trabajo de campo, así como las diferentes publicaciones consultadas, dan cuenta que esa "imagen" de la religiosidad correntina operó como norma de "lo memorable" en la fotografía hasta al menos entrada la década de 1980. Sólo desde entonces fue posible advertir la proliferación de imágenes de la heterogeneización del campo religioso argentino y correntino.

La historización parcial de este proceso de in-visibilización da cuenta que fuera de los archivos oficiales visitados - donde la ausencia de tomas de cultos populares es evidente- las imágenes de la religiosidad popular, en general, y del Gauchito Gil, en particular, empezaron a difundirse gracias al auge de las narrativas del melodrama. Hablamos de historias y relatos protagonizados por los sectores populares que empezaron a mostrar las pantallas del cine y las portadas de otros formatos de comunicación masiva desde la década de $1960^{145}$. De allí emergen "imágenes" que dan a ver prácticas rituales, mitos y héroes populares y que, a su vez, vienen a responder al horizonte de expectativas de los públicos masivos heterogeneizados y con demandas de consumo también diversificadas ${ }^{146}$.

En este contexto, hacia fines de los años sesenta las revistas Siete Días, Panorama, el diario La Razón, empezaron a dar a ver los cultos relacionados a San La Muerte, la cultura afrobrasileña o los milagros de la Difunta Correa en San Juan, la que se convirtió años después en la santa popular más mediática. Mientras que en los años ochenta se advierten notas como las que saca La Prensa en $1980^{147}$ marcando el ingreso del caso y las fotografías de altares del Gaucho Gil a la esfera mediática nacional, aunque casi sin referencias de relevancia a nivel de la prensa provincial.

\footnotetext{
145 La cuestión de las narrativas del melodrama y su vinculación con la fotografía referida al Gaucho Gil desarrollada en el Capítulo 6.

${ }^{146}$ En este sentido, serán centrales las narrativas del cine de la década del 60 y 70 que darán imagen y audibilidad a historias como las de los gauchos rebeldes como Martin Fierro de Leopoldo Torre Nilson, o Juan Moreira de Leonardo Fabio, entre otras propuestas reivindicadoras de las demandas populares, incluso con prédicas revolucionarias como las de Tercer Cine.

${ }^{147}$ Si bien hay algunas referencias precedentes en otros medios, la nota de 1980 de La Prensa que lleva por título "Antonio Gil, el gaucho de los desamparados" es una de las pocas publicaciones de la época que le dedica una página completa a la devoción y marca una valoración del santo ligada a los sectores populares no sólo correntinos sino del conurbano bonaerense. El artículo pone a circular una versión de la leyenda del Gaucho con fotos de altares de devotos de la provincia de Buenos Aires.
} 

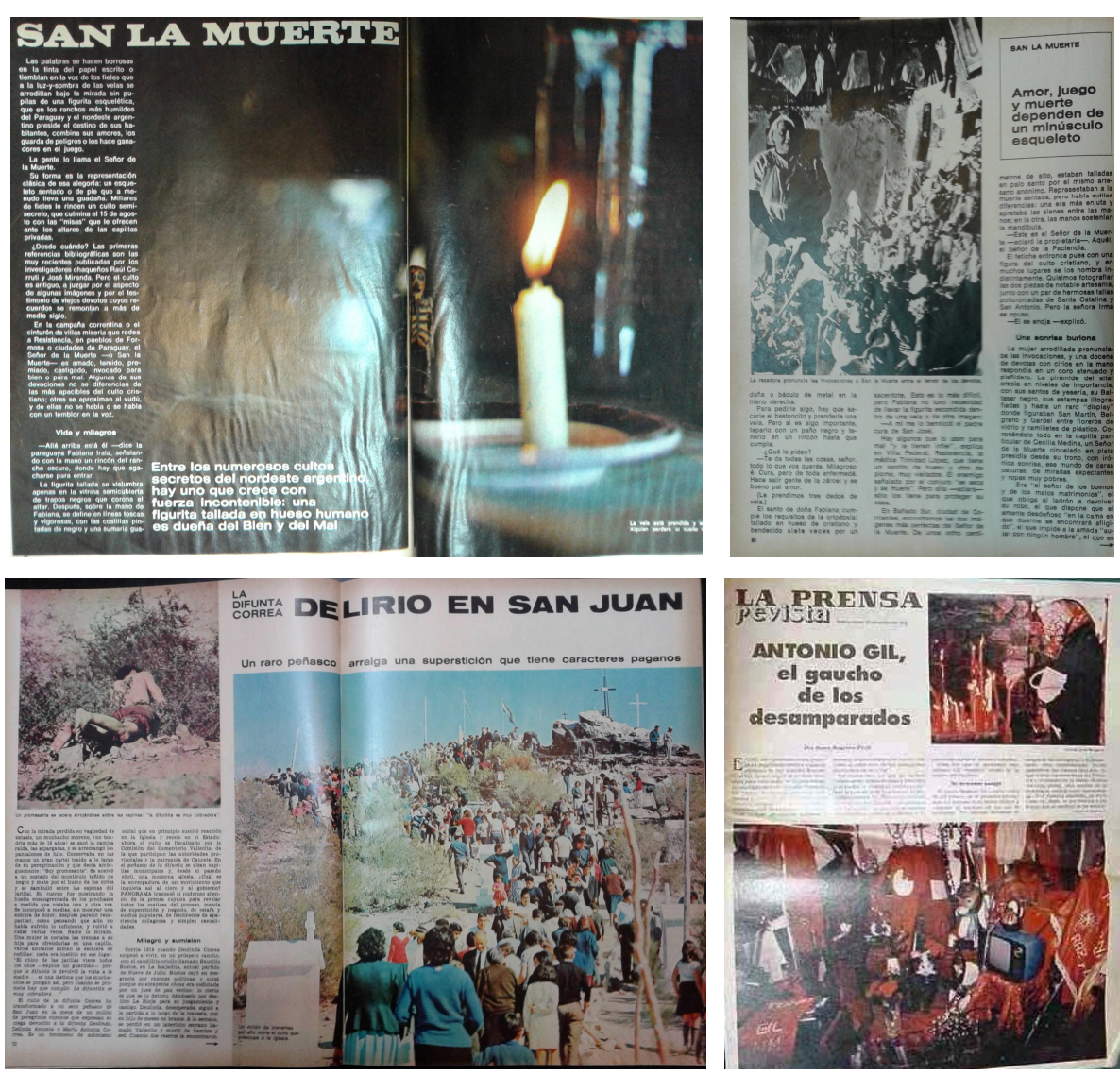

Arriba: Nota de Rodolfo Walsh en revista Panorama sobre San La Muerte realizada durante su visita al Nordeste. Noviembre de 1966. Abajo: Nota sobre la expansión de la devoción a la Difunta Correa en Panorama. Agosto de 1966. Suplemento de diario La Prensa Nota sobre Antonio Gil. Enero 1980.

A mediados de los años noventa, junto al devenir de la hipervisibilidad de fenómenos de fe multitudinarios ligados a la muerte de los cantantes de música popular Gilda y Rodrigo, la festividad y la figura del Gauchito Gil gana protagonismo; primeramente, lo hace en las capillitas que le erigen sus fieles a lo largo de las rutas de todo el país, luego cobra relevancia para los medios por la masividad de devotos que congrega el santuario central en Mercedes ${ }^{148}$. La masividad funciona, junto a otros elementos noticiables (como la rareza, espectacularidad de los rituales etc), como uno de los factores de noticiabilidad principales que atrae a la prensa nacional e internacional. A partir de 2010 la cobertura anual de la festividad del 8 de enero se instala en la agenda de la mayoría de los medios ${ }^{149}$.

\footnotetext{
${ }^{148} \mathrm{El}$ crecimiento de fieles desde fines de los noventa y principios de los años 2000 es exponencial. Algunos registros consignan alrededor 50 mil personas en 1999, lo genera un antes y un después en la difusión mediática. Entre 2008 y 2011, las crónicas del 8 y 9 de enero consultadas arriesgan números exorbitantes: hablan de entre 250 y 700 mil visitantes los días de la festividad central.

${ }^{149}$ De la Tv nacional se destacan informes anuales de Crónica, Telefé, Canal 13, TV Pública. También NatGio inaugura una serie de documentales en 2011; se suman informes y documentales audiovisuales de BBC, AFP, AP, entre otros, que pueden verse en la web y que abonan la visualidad y audibilidad expandida del fenómeno con diversas connotaciones.
} 
Si bien esa hipervisibilidad colaboró en la expansión de la devoción popular, las orientaciones ideológicas del discurso periodístico y massmediático sobre las prácticas socioculturales vinculadas a la figura de Gil estuvieron desde el inicio de su difusión masiva predominantemente marcadas por tonos despectivos.

Por un lado, los periódicos y programas televisivos sensacionalistas, nacionales e internacionales, se encargaron de explotar el lado "raro" y "exótico" de las imágenes festivas en torno al "santo" popular, construyendo a estas prácticas y las poblaciones que las invisten de sentido como el "otro" que un "nosotros" observa y descubre desde la extrañeza. Por otro lado, cientos de informes enfatizaron el anclaje de "la imagen" de esta devoción en el lugar de la "barbarie" 150 a partir de la vinculación del Gaucho Gil al delito. Esta relación se construyó basado en el crecimiento de su veneración en el ámbito carcelario, por su presencia sincretizada dentro en los santuarios de San La Muerte y los templos Umbanda ${ }^{151}$ y también por el incremento de su devoción en los barrios marginales; todas figuras, rituales religiosos y franjas de la población históricamente criminalizados por el discurso de la prensa hegemónica.

En esta línea, también los medios tradicionales y conservadores provinciales -con posición dominante en la provincia de Corrientes y con una línea editorial de marcada orientación católica ${ }^{152}$ - incluso durante la primera década de los años 2000 continúan en su mayoría calificando a las prácticas de veneración al Gaucho Gil como "superstición”, en consonancia con el discurso histórico eclesiástico. Si bien, esta valoración discursiva empezó a redefinirse cuando las propias jerarquías eclesiásticas plantearon en los primeros años de 2000 un acercamiento al santuario mercedeño, la mayoría de los medios de prensa no lograron desligarse de las viejas valoraciones que le asignaban el estatus de "desviado" y hasta “demoníaco" o "satánico" a las devociones populares ${ }^{153}$.

${ }^{150}$ Refiere a la oposición sarmientina civilización-barbarie que se ha constituido en un "marco interpretativo de la realidad argentina" de larga tradición desde el siglo XIX, una forma de "leer" en términos políticos a los sujetos y a la cultura popular; o en términos de Frigerio (2008) siguiendo a Svampa, una de las "principales varas con las que se mide la posibilidad de integración (o no) de determinados grupos" sociales a la nación y donde aquello que se construye por oposición o al margen de la "Argentina Blanca, Europea, Moderna, Racional y Católica" es invisibilizado o excluido.

151 En varios escritos, el antropólogo Alejandro Frigerio cuestionó la criminalización de estas devociones populares. En un análisis pormenorizado de tapas periodísticas vinculadas a San La Muerte, Gauchito Gil y la religión Umbanda, y la construcción de "sectas" en programas de televisión, que puede leerse en la página web del académico (http://www.alejandrofrigerio.com.ar/), Frigerio insiste en que la creencia en estas figuras no promueven ni apañan el delito.

${ }^{152}$ Esto se deduce de diversos estudios de análisis del discurso de la prensa gráfica correntina, en particular del diario El Litoral, Época y El Libertador, que se han realizado en tesinas de grado de la Licenciatura en Comunicación Social de la UNNE.

${ }^{153}$ Un ejemplo cabal es el texto "En Corrientes, la devoción a los 'santos' de cabecera no distingue religiones" del diario Época en 2007. La nota cuenta del incremento de la devoción a San La Muerte y El Gauchito Gil y en 
En 2005 se dio la primera visita de un obispo católico a la Cruz Gil. Sin embargo, el mensaje del prelado Ricardo Faifer insistió en aquella oportunidad: "Nuestro interés es encauzar la fe de nuestro pueblo"154. En esta línea, siguieron diversas pronunciaciones de la Iglesia. Por ejemplo, en 2011, Faifer hizo público en la misa del 8 de enero en Mercedes un nuevo manifiesto eclesiástico donde dejaba claro que Antonio Gil sólo puede ser recordado como difunto y no como santo, haciendo hincapié a su vez en revalorizar el "verdadero" significado de profesar el cristianismo: "Quien se santigua ante la cruz está profesando su fe en Jesucristo (...) quien es nuestro mediador supremo entre Dios y los hombres" y en este sentido la carta firmada por Faifer reclamaba que la devoción se centre en la cruz de Jesús y no la del "difunto" 155 .

En este marco, la Iglesia instrumentó una serie de medidas para intervenir en el santuario del Gaucho Gil y seguir su cometido de "encauzar" la fe. Entre ellos se cuenta entre 2010 y 2011 la compra de un terreno a 500 metros a la Cruz Gil para erigir la Cruz de Cristo y una capilla como lugar destinado a la oración y veneración de Jesucristo por parte de los propios peregrinos de Gil. En una entrevista con AFP el sacerdote de la Parroquia de Mercedes, Luis María Adis señaló en relación a la iniciativa: "Cada año es peor. No hay espacio de oración y es lo que, en el fondo, nos lleva a esta decisión. Queremos, desde nuestro lugar, encauzar la religiosidad popular. No queremos hacer competencia a nadie"156.

Lo que observamos hasta aquí es cómo la Iglesia, los medios de comunicación en general, periodistas como formadores de opinión, junto a otros estamentos del Estado y la sociedad, cumplen funciones de regulación en relación al lugar que ocupa la devoción del Gaucho Gil en el orden social vigente. En otras palabras, a partir de formas de clasificación, orientación ideológica de los discursos, el descrédito e incluso la oclusión de las prácticas vinculadas a la devoción del Gaucho Gil, estos actores operan propiciando un orden de invisibilidad y estigmatización de la diversidad religiosa.

No obstante, así como algunos grupos sociales colaboran en la construcción de una imagen desviante y estigmatizada de esta devoción popular, también aparecen con fuerza en la escena de los años 2000 aquellos devotos y también "simpatizantes" que no se reconocen

sus líneas resalta que "no es una novedad encontrase con la conjunción de cultos paganos o "sincretismo de fe", o no aceptados por la Iglesia Católica, donde se realizan ritos oscuros o denominados satánicos. Nota diario Época, Corrientes, 28 de agosto de 2007. Sección Información General. Pág. 21. El subrayado es nuestro.

${ }^{154}$ Cita nota Agencia Télam, Buenos Aires, 9 de enero de 2005. El subrayado es nuestro.

155 Referencia nota periodística diario El Libertador, Corrientes, 9 de enero de 2011, Sección Interior. Pág 15. En este sentido también se expresan una serie de escritos titulados "Novena a la Cruz Gil. Recordando a Antonio Gil y a los difuntos" y "Carta a los peregrinos de la Cruz Gil" difundidos en 2012 y 2013 por el obispado de Goya y pueden leerse en la página de la Agencia Informativa Católica Argentina: http://www.aica.org/.

${ }^{156}$ Nota AFP, Mercedes, 8 de enero de 2011. 
devotos de la figura de Antonio Gil que promueven su difusión con una entonación valorativa diferente. Estos grupos están conformados por periodistas, fotógrafos, productores audiovisuales, cineastas, artistas performáticos, músicos que insertan diversas referencias del Gauchito Gil no sólo en los medios tradicionales, sino también en "nuevos medios" que se tienen la web y espacios de exposición/mostración de prácticas artísticas diversas.

En el ámbito de la fotografía específicamente, las formas de autorrepresentación de los creyentes fueron cruciales en la propagación de la devoción. Sin embargo, estas formas de representación no fueron posibles hasta mediados del siglo $\mathrm{XX}$, cuando en el país, $\mathrm{y}$ principalmente en Corrientes, proliferaron las cámaras baratas y la reproductibilidad en serie a menor costo, posibilitando la emergencia de los denominados "fotógrafos de pueblo". Estos fotógrafos trabajaban en las zonas rurales y entre los sectores populares atendiendo una demanda que no cubrían los estudios de fotografía instalados en las ciudades capitales, como las de Alberto Ingimbert, entre otros, o la fotografía de viajeros. También, entre 1960 y 1980 la tecnología fotográfica empezó a formar parte de la adquisición de familias de los sectores populares.

Ese contexto configuró las condiciones de emergencia de las "fotos de familia" también dentro de los sectores menos acomodados de la sociedad correntina, abonando en el caso mercedeño la existencia de retratos y tomas generales de la devoción y santuario en la Cruz Gil. Hablamos de fotografías que datan de la década del sesenta, setenta y ochenta resguardadas en álbumes de familia, relevadas durante nuestro trabajo de campo en Mercedes. Sin embargo, estas imágenes quedaron y aún forman parte del seno privado hasta que a fines de la primera década de 2000 algunas de ellas empezaron a ser difundidas a través de las redes sociales por los mismos protagonistas de las imágenes. La red más popular para este fin es Facebook. Allí las familias devotas y algunos aficionados a las fotos del recuerdo comparten fotografías, comentan y hasta debaten extensamente en torno a ellas. También de 2010 en adelante proliferó la utilización de Youtube por parte de los promeseros que crean videos contrastando algunas imágenes analógicas digitalizadas junto a imágenes digitales actuales, junto a otros recursos, para re-crear diferentes versiones de la leyenda del Gaucho Gil. Estas producciones, en la mayoría de los casos subvierten las orientaciones negativas de los discursos de prensa para reivindicar la figura del "santo" popular.

En este marco, también entran a disputar sentidos las fotografías de "autor", entre ellas las de los fotógrafos que en el Capítulo 5 abordamos en detalle: Juan Pablo Faccioli, Guillermo Rusconi, Estela Izuel, Eduardo Longoni y Marcos López. Si bien, buena parte de estas imágenes fueron producidas para su circulación en la prensa gráfica o espacios de arte 
(museos, galerías, etc) también todos los autores se encargaron de poner a circular sus producciones en la web. Sobre todo, los fotógrafos pusieron a circular en internet aquellas imágenes que responden a sus búsquedas personales documentales/artísticas, más desligadas de las demandas massmediáticas que forman parte de producciones fotoperiodísticas como las de Faccioli y Rusconi-.

Además de las páginas web y blog personales que son muy utilizadas por Izuel, Longoni y López; podemos citar también Flickr, la red social más usada por los fotógrafos profesionales debido a que permite compartir imágenes en tamaño completo, información de toma, contexto, añadir gran cantidad de imágenes sin perder calidad y sostener contacto fluido con suscriptores. Esta red es muy usada por Faccioli y Rusconi. También se pueden ver sus trabajos en la red social de fotoperiodistas iberoamericanos Nuestra Mirada y la página web de la Asociación Argentina de Reporteros Gráficos de la República Argentina ${ }^{157}$. Eduardo Longoni particularmente concibió un e-book en la plataforma ISSUU, titulado Superficies donde comparte el ensayo "La Fe en la Piel" junto al trabajo "Otras Latitudes" de su colega Jorge Piccini. Desde la web del fotógrafo, en la sección Libros, se lee una introducción donde se pone el acento no sólo en cómo la fotografía sólo cobra sentido con la mirada de quien la interpreta sino se rescata las potencialidades de los libros digitales como dispositivo válido para dar a ver las imágenes:

Dicen que todo poema está incompleto hasta que no encuentra un lector, y es posible que una foto recién se complete cuando una mirada se posa sobre ella. Mientras tanto, miles de fotos se acurrucan en cajones y estantes $\mathrm{y}$, en estos tiempos, millones apenas tienen una tenue vida latente en los discos rígidos de las computadoras.

Son los libros de fotos los que hacen revivir a las imágenes, les brindan sentido, las hacen decir. Durante años el papel fue el único soporte posible, y las imprentas muchas veces hacían naufragar los sueños de los fotógrafos. Bien porque el precio era tan alto que el proyecto se truncaba, o bien porque la calidad de la impresión no siempre respetaba los tonos que cada autor tenía en mente. Los libros digitales vienen a ocupar un lugar novedoso en este panorama $^{158}$.

Lo interesante de la socialización de imágenes a través de estos "nuevos medios", y la participación manifiesta de los fotógrafos con sus producciones en el esquema de la convergencia digital, es que las producciones no sólo se ponen a circular utilizando las nuevas tecnologías de la informática, sino que se consumen y re-crean a través de ella. Asimismo, al estar dotados por un código digital, es decir, al ser representaciones numéricas

157 Se puede acceder a las páginas desde los siguientes links: http://www.estelaizuel.com/; http://www.marcoslopez.com/; $\quad$ http://www.marcoslopez.com/, $\quad$ http://www.nuestramirada.org/; https://www.flickr.com/photos/facciolijuanpablo/; $\quad$ https://www.flickr.com/photos/guille_rusconi/; http://www.argra.org.ar/

${ }^{158}$ Ver más en: http://www.eduardolongoni.com.ar/. El link del e-book donde se exponen las 22 fotografías que conforman el ensayo del Longoni es: http://issuu.com/disenador/docs/superficies?e=1383529/5944800 
como plantea Manovich (2005) las formas que ponen en escena estos medios no sólo permite acceso, consulta, sino también su archivación, manipulación y re-producción en nuevos dispositivos y direcciones de la web.

De este modo, la comunicación en los nuevos medios abre otro cambio de paradigma, otra "franja de indeterminación" atravesada por transformaciones socio-culturales y tecnológicas que inauguran una nueva forma de uso, producción, valoración de imágenes del mundo del Gaucho Gil.

\section{Notas finales sobre la des-estabilización de representaciones la religiosidad correntina}

Llegados a este punto de exploración de las representaciones de larga duración de la religiosidad correntina a partir de las fotografías, vale volver a preguntarnos ¿cuáles fueron los asuntos, tópicos y personajes privilegiados en las tomas fotográficas precedentes esas últimas décadas del siglo XX? y ¿cómo fueron mostrados?; ¿cuál fue el lugar de la referencia de las prácticas de religiosidad correntina, en general, y las vinculadas a las figuras populares como el Gauchito Gil, en particular, en las fotografías históricas?; ¿por qué o ligadas a qué condiciones y sistemas socio-culturales y discursivos de valoración las imágenes del Gaucho Gil recién aparecen a fines del siglo XX y proliferan con fuerza a principios del siglo XXI?; y si uno contrasta esas fotos históricas en vinculación a formaciones discursivas específicas con las imágenes y los discursos construidos por los medios tradicionales y los denominados nuevos medios a partir de la década de 1980, 1990 y 2000: ¿en qué medida se puede hablar de continuidades y/o discontinuidades ${ }^{159}$ en los modos de mirar y re-presentar la religiosidad correntina? y ¿cómo estos nuevos dispositivos inciden en las formas de construir memorias y representaciones identitarias?

De lo indagado, en la línea de estos interrogantes hasta aquí observamos cómo algunas fotografías capturadas a principios del siglo XX construyeron una representación hegemónica de la religiosidad correntina; y lo hicieron emparentadas a otros textos, atendiendo a una determinada formación discursiva y social y a los juegos de saber/ poder que en ella se entretejen.

\footnotetext{
${ }^{159}$ Mientras la continuidad es el lugar de los relatos homogéneos, de las regularidades, la discontinuidad, según Foucault, se configura como el umbral, el lugar de "ruptura, corte, mutación, trasformación". Es el "límite de un proceso, el punto de inflexión de una curva, la in-versión de un movimiento regulador, los límites de una oscilación, el umbral de un funcionamiento, el instante de dislocación de una causalidad circular" (Foucault, 1991: 13-14).
} 
Las fotos históricas, en su mayoría restringidas a la referencia de cultos católicos según lo relevado, fueron utilizadas para perennizar una "historia oficial" consecuente con memorias e identidades pretendidamente unitarias ligadas a los procesos de conformación de la nación moderna argentina. Hablamos de "una historia" que se cuenta a través de las imágenes pero asociadas a diversas operaciones discursivas que incluyen nominaciones lingüísticas con determinada acentuación ideológica, estrategias de clasificación, ordenamiento, resguardo, visibilización, ocultamiento, reproducción en el ámbito de ciertos dispositivos, tales como los archivos, los álbumes y los medios de comunicación masiva.

Lo analizado confirma cómo los regímenes de visibilidad tienen una presencia constitutiva y material en la forma de construcción de representaciones sociales. No obstante, para entender cómo estas representaciones - que a su vez actúan modelando creencias, acciones, formas de mirar, de concebir el mundo- se reconfiguran es necesario entender cómo los discursos circulantes -incluyendo aquí los visuales- se transforman en estrecha vinculación a las formaciones socio- económicas, políticas y culturales también cambiantes.

Así, frente a la predominancia de la visibilidad de las prácticas religiosas ligadas a la religión católica durante buena parte del siglo XX, hacia los años 1980 con un contexto diverso al de inicios del siglo -signado entre otros procesos por el retorno de la democracia al país, la expansión de la cultura mediática y la diversificación religiosa- es posible advertir la reactivación de algunos repertorios de "lo popular". Con ello se da también la irrupción de la figura y la festividad del Gaucho Gil en los discursos massmediáticos y la proliferación de la devoción a partir de nuevos medios en la red y en las producciones visuales (artísticas, documentales, periodísticas) de la primera década del siglo XXI, entre otras formas de inscripción ${ }^{160}$. Este escenario da cuenta de ciertos descentramientos de las miradas y las memorias y como correlato procesos de des-estabilización de las representaciones heredades que también se traducen en las formas de re-presentar la religiosidad correntina a través de la fotografía ${ }^{161}$.

En resumen, volviendo a lo planteado por Rossana Reguillo (2008), los trastocamientos de los regímenes de visibilidad dominantes que implican los fenómenos descriptos aceleran el pasaje de la era de la visualidad disciplinaria, institucional propia de los sistemas de representación dominados por una élite social y política conservadora del siglo XX a formas más interactivas y plurales de comunicación del siglo XXI. Si bien, en estas nuevas maneras de socialización perviven representaciones dominantes que siguen moldeando

\footnotetext{
${ }^{160}$ Inscripciones y formas de expansión de la devoción que se desarrollan en detalle en el Capítulo 3.

${ }^{161}$ La idea de "descentramientos de las miradas" es analizado con mayor detenimiento en el capítulo siguiente.
} 
las modos de concebir el mundo, también en ellas se abren paso otras formas de mirar y de crear significaciones en torno a "lo religioso" y la religiosidad correntina. Sobre todo a partir de la visibilización de la religiosidad de los sectores populares como la que representa el mundo del Gaucho Gil.

Llegados a este punto y en vinculación a las reflexiones sobre fotografía, archivo, memoria y representaciones identitarias, consideramos necesario atender los procesos de simbolización cambiantes, la complejización de ámbitos de producción y la bifurcación de vías, plataformas de circulación/mostración y consumo en las que se insertan las imágenes de interés. Entendemos estas transformaciones impactan de lleno en las formas de inscripción de nuevas necesidades de representación en la sociedad, generando a su vez otros procedimientos, la alteración de los dispositivos y/o sustitución de unos dispositivos por otros, para satisfacer esos nuevos requerimientos de representación.

De este modo, actualmente frente a grupos heterogéneos con necesidades también heterogéneas y con acceso a dispositivos de captura, registro, conservación y reproducción electrónicos-inteligentes, como indica García (2004), la constitución y administración de un acervo colectivo que pudiera llegar a ser representativo de una "memoria" nacional o provincial excede ampliamente la propuesta estática de los archivos visitados. Sin dejar de marcar las limitaciones justamente de ese "acceso" por parte de muchos grupos sociales marginalizados y también sin desatender las contradicciones que platean esas nuevas formas de comunicación "plural” en la cultura global ${ }^{162}$-, es claro que los archivos que se guían por parámetros de manejo anclados en los valores de fines del siglo XIX y principios del XX que instauraron $\mathrm{y}$ siguen reproduciendo estereotipos identitarios- se perciben bastante acotados frente a los requerimientos contemporáneos.

${ }^{162}$ Consultar al respecto el texto "Comunicación: el descentramiento de la modernidad” de Jesús Martin-Barbero (1996) 


\title{
CAPÍTULO 5:
}

\section{Fotografías del Gaucho Gil. Descentramientos de las miradas en cinco} producciones

\begin{abstract}
Todo régimen de in-visibilidad comporta una franja de indeterminación potencialmente transformadora. Aquello que era in-visible de un modo dado por las lógicas del poder se transforma en virtud de la acción de algunos actores en situaciones históricas particulares (...) Y es esta condición, la de su potencial transformador, la que vuelve amenazantes los mundos de la visibilidad.
\end{abstract}

\section{Rossana Reguillo, Políticas de la (In)visibilidad. La construcción social de la} diferencia

Así como cada mirada se construye en la interpelación constante de aquello que considera merece ser visibilizado y ocultado, condicionada por los "regímenes de visibilidad" que establecen los parámetros de lo digno e indigno de dar a ver (Reguillo, 2008), en este capítulo se multiplican las preguntas en torno a los modos y los contextos en que ciertas formas de ver y representar la religiosidad correntina se "descentran" de esos marcos regulatorios para propiciar repertorios alternativos al régimen visual dominante.

Atendiendo al pensamiento de Jacques Rancière, los descentramientos aluden a aquellas miradas que trabajan, con mayor o menor éxito, por la construcción de "otras formas de sentido común, es decir otros dispositivos espacio-temporales, otras comunidades de las palabras y las cosas, de las formas y de las significaciones" (Rancière, 2010: 102).

En este sentido, este escrito se concentra nuevamente en explorar la dimensión política de la mirada; es decir, su capacidad para establecer -en función de ciertos paradigmas histórico-culturales- vigentes una re-distribución de lo sensible - siguiendo a Rancière- , haciendo visible aquello que no lo era, subvirtiendo el reparto jerárquico basado en operaciones de exclusión/inclusión que establece la mirada disciplinaria y normalizadora.

Partiendo de estas lecturas, nos interesa aquí atender el trayecto de algunas miradas, que en tanto concepciones de mundo, se materializan en producciones fotográficas concretas. Hablamos de imágenes de la festividad religiosa del Gaucho Gil capturadas en la localidad de Mercedes, Corrientes; así como algunas recreaciones visuales de estudio inspiradas en la figura del "santo" popular. Se trata de fotografías tomadas entre 1999 y 2013 por Juan Pablo 
Faccioli, Guillermo Rusconi, Eduardo Longoni, Estela Izuel y Marcos López, cuyos géneros discurren entre el fotoperiodismo, la documentación y el arte.

A partir de dicho corpus indagamos cómo las formas de ver y representar el mundo del Gaucho Gil se desmarcan de los modos de organización/composición que impone el régimen visual dominante para inscribirse en uno alternativo (Jay, 1988; Poole, 2000), propiciando la reconfiguración de los modos históricos de representar la religiosidad correntina. Ello entendido dentro las limitantes que impone el propio proceso hegemónico del que estos modos de visualidad forman parte (Caggiano, 2012).

Nos focalizamos entonces en explorar la reconfiguración representacional fotográfica de la religiosidad correntina, entendiéndola como un proceso de larga duración que es posible por la puesta en funcionamiento de mecanismos de descentramiento de la mirada que actúan produciendo en determinados estados de sociedad alteraciones y/o reforzamientos de los regímenes de visibilidad y ocultamiento imperantes (Reguillo, 2008; Rancière, 2010).

En términos operativos analíticos, damos cuenta de esos mecanismos a partir de la reflexión contrastiva de los modos de mirar que traducen las imágenes actuales, de los cinco autores seleccionados, con las que textualizan las fotografías históricas indagadas en archivos y algunas publicaciones mediáticas, cuyo desarrollo se articula con lo escrito en el Capítulo 4.

En esta línea, se identifican las estructuras y los contenidos representacionales, aquello que las imágenes dan a ver y los modos de mostración. Es decir, se presta atención a las formas visibilización/ocultamiento de determinados objetos, prácticas, personajes, jerarquías; modalidades estéticas y de organización compositiva predominante; así como las formas de vinculación de estas imágenes con otros textos y sus condiciones de producción/circulación/recepción.

Asimismo, el análisis de los diferentes modos de dar a ver el mundo del Gaucho Gil de los cinco fotógrafos mencionados se plantea en la ordenación de este texto a modo de pasajes de un tipo de recorte a otro y de una búsqueda conceptual a otra. En esos pasajes se observa cómo condicionadas por un punto de vista en la producción y de su posterior valoración en la circulación, las imágenes pueden ser investidas de diversos sentidos.

\section{Estructuras de composición de un paradigma de representación hegemónico}

La búsqueda de imágenes de la religiosidad correntina en los archivos históricos nos permitió observar, tal como se expone en el Capítulo 4, que prácticamente todas las fotografías de prácticas religiosas correntinas que se conservan de fines de siglo XIX y buena 
parte del XX remiten a ritos oficiales católicos. Ahora bien, si se realiza un análisis detenido en las estructuras ordenadoras de los elementos que presentan dichas imágenes, es posible advertir que estas representaciones fueron construidas y mostradas según las directrices del paradigma eurocéntrico eclesiástico. Un modelo tendiente a realzar la magnificencia y la jerarquía de los rituales a través de tomas de planos generales de principio estilístico descriptivo y estático.

Hablamos de fotografías que re-producen en su mayoría la ordenación de posiciones que la Iglesia articula en los rituales (la procesión, la misa etc) propiamente dichos para instaurar la subordinación del colectivo a la imagen venerada y a las investiduras eclesiásticas, a cuya par aparecen los representantes del poder gubernamental establecido. Ese modo de construir visualidad e in-visibilidad confirma cómo la misma práctica socioreligiosa, que se manifiesta y se instituye a través de la reproducción de normas y valores, es la que prefigura la práctica de fotografiar y la foto resultante.

Cabe señalar que la disposición de elementos en la composición de cada fotografía constituye una operación vital para garantizar la vehiculización de visiones a través de ellas. Cada elección dentro de la ordenación/composición encierra las “definiciones dominantes de la situación y representan o refractan las estructuras existentes de poder, riqueza y dominación" y esa reproducción de estructuras dadas constituye muchas veces "un proceso que ha llegado a ser inconsciente incluso para los codificadores” (Hall, 1981:23).

A modo de ejemplo, esto implica que la virgen, el santo o la cruz ocupan el núcleo de la práctica ritual de manera diferenciada y distinguida en torno al cual se ordenan la aparición de sacerdotes y las autoridades del gobierno municipal, provincial y nacional, también singularizados, y finalmente los devotos recluidos hacia el borde pero no menos importante porque conforman la masa uniforme, indiferenciada, que sostiene el orden dominante. $\mathrm{Y}$ es esa la estructura de ordenación simbólica que se actualiza en las fotos, dotándolas así de capacidad de incidir, interpelar, persuadir al espectador en la aprehensión de normas de valoración y acción. 


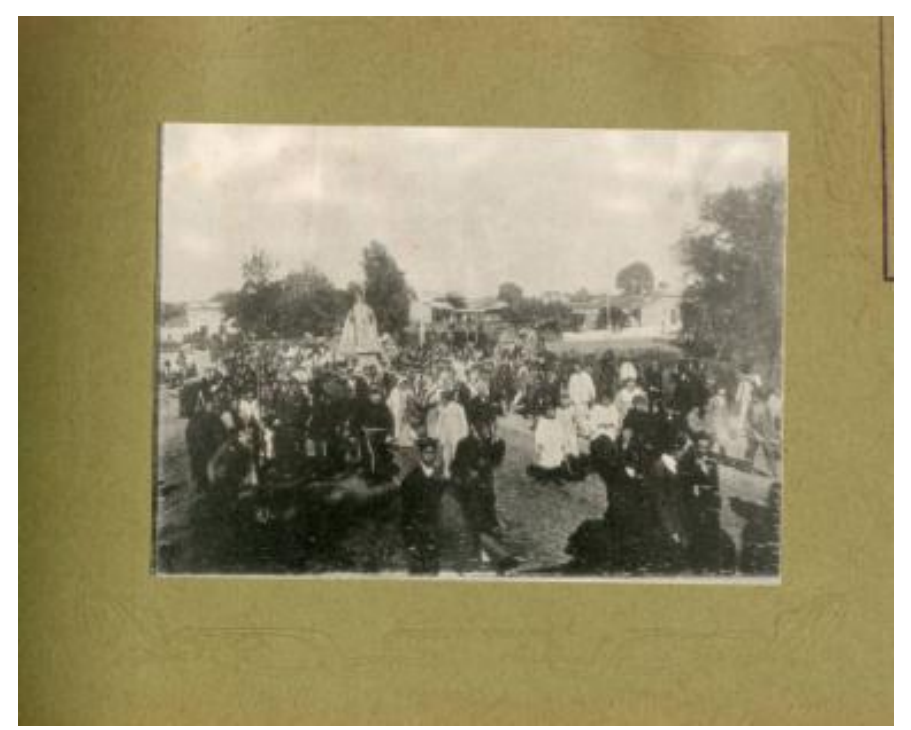

Alberto Ingimbert. Procesión de la Virgen de las Mercedes para la Misa de Campaña. 1910. Álbum Gráfico. Col Museo Histórico de Corrientes.

Este tipo de fotografías, en el caso correntino construidas sobre una plataforma mediática, en la mayoría de los casos, sustentada por lazos entre eclesiásticos y caudillos terratenientes devenidos en dirigentes políticos y en dueños de medios masivos del siglo pasado, signaron y condicionan hasta la actualidad la estructuración y la acentuación ideológica de la producción fotográfica de difusión masiva (Barrios, 2011). Asimismo, las representaciones materializadas en esas capturas incluso actúan modelando con su lógica de jerarquización también las fotos contemporáneas referentes a las prácticas de religiosidad popular no católica que circulan en diferentes plataformas de comunicación masiva.

Dentro de la vasta producción que puede realizar un reportero gráfico en la cobertura de festividades populares, como la misma festividad del Gaucho Gil, los medios en general privilegian para su publicación las tomas que siguen formas de composición tradicionales. Hablamos de capturas donde se distinguir en una ubicación privilegiada dentro del recorte ya sea el centro de la escena en una toma general o el primer plano en una toma más cercanala visibilización de determinados personajes y símbolos que se consideran claves por su rol o representatividad dentro de los rituales institucionalizados de las festividades; así como las capturas que muestran la masividad para exaltar la grandilocuencia y la relevancia del tema en cuestión vinculado a la cantidad de personas que interesa e involucra. 


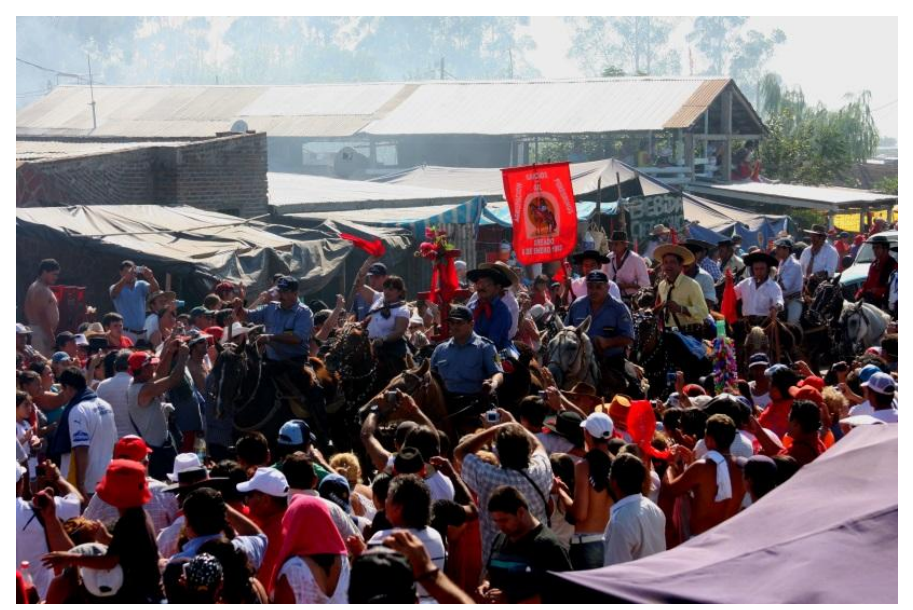

Juan Pablo Faccioli Gaucho Gil, Mercedes 2012.

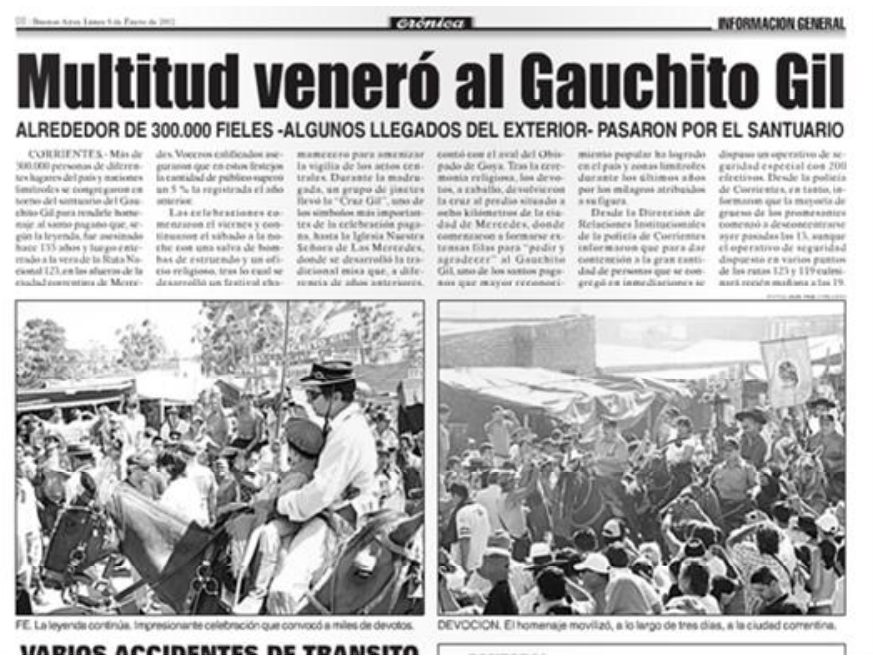

Págs. Información Gral., Diario Crónica. Fotografías Juan Pablo Faccioli Gaucho Gil, Mercedes 2012

Si nos detenemos en el caso del diario Crónica con las fotografías de Faccioli, observamos la reproducción de esquemas representacionales heredados del paradigma eclesiástico y una tendencia propia de los medios - sobre todo se da como constante en los medios tradicionales y conservadores- a resaltar ciertos valores de la organización social tradicional, católica, patriarcal local, en este caso focalizando en uno de los rituales más formalizados que posee la festividad del Gaucho Gil. Se trata de la procesión que realiza todos los años la agrupación Gauchos de Antonio Gil con la Cruz Peregrina a la Iglesia de la Merced, custodiada por las fuerzas de seguridad provinciales. El acto no sólo se asocia al culto católico sino plantea como protagonistas a la Cruz y a los gauchos tradicionales correntinos que desde esta imagen actualizan su liderazgo dentro del esquema social local. 
Estos ejemplos, sumados a algunos citados en el Capítulo 4, muestran que los medios en general asumen el rol de "reguladores discursivos" clave para el mantenimiento del status $q u o$ establecido dentro de la organización social ${ }^{163}$. Una regulación que actúa en la consideración colectiva de Corrientes como una sociedad conservadora, heroica, clerical, católica y tradicional en el imaginario nacional (Martin-Barbero, 1989; Barrios, 2011).

No obstante, los medios en ocasiones también se construyen como espacios de emergencia de relatos "otros" signados en la concepción de sus contenidos por un cambio de época, por transformaciones políticas y culturales. Específicamente en este caso, resultan relevantes los procesos de heterogeineización de las prácticas religiosas y la diversificación de formas de comunicación que, como se observó detenidamente en los capítulos anteriores, provoca el corrimiento de esos marcos regulatorios y otorga visibilidad a personajes, prácticas, festividades de los sectores populares antes invisibilizados.

En esta línea, observamos que si bien muchos esquemas representacionales dominantes siguen vigentes y se reproducen actualizando las miradas hegemónicas de la religiosidad correntina, también hay concepciones descentradas de esos paradigmas que hacen ingresar al plano de las re-presentaciones fotográficas elementos residuales referenciales de la cultura popular, en su mayoría provenientes de formaciones sociales pasadas, y también formas emergentes que aluden nuevas prácticas, valores y procesos de intersección entre las culturas que atraviesan las prácticas de religiosidad contemporáneas.

De allí, resulta relevante para nosotros explorar los modos en que las fotografías del Gaucho Gil de los cinco fotógrafos seleccionados se configuran como espacios de confrontación de formas "dominantes residuales y emergentes" (Williams, 1980) de la religiosidad correntina; y cómo estas imágenes suponen desde su construcción la intersección de miradas, diálogos, conflictos y disputas por la visibilidad.

\section{De la toma descriptiva- estática al retrato en acción y la captura de la atmósfera cultural}

Las disputas y relaciones de fuerza que se ejercen desde los sectores interesados por la dominación simbólica en el plano de la religiosidad tienen su correlato en la fotografía actual. Un movimiento que rompe con el monopolio del catolicismo visibiliza una religiosidad

${ }^{163}$ De hecho ya describía Hall la relevancia de los medios masivos de comunicación como constructores selectivos del "conocimiento social, de la imaginería social por cuyo medio percibimos los 'mundos', las 'realidades vividas' de los otros y reconstruimos imaginariamente sus vidas y las nuestras en un 'mundo global' inteligible, en una 'totalidad vivida"” (Hall, 1981:20). 
cristiana que no es sólo católica así como nuevas experiencias de religiosidad con sedimentos revitalizados de otros orígenes culturales.

En este marco, la fotografía contemporánea de las prácticas de religiosidad popular correntinas que no abandona del todo la lógica estructuración iconográfica que privilegia los planos generales más bien estáticos tendientes a enfatizar las multitudes en los rituales, en torno a la imagen de la divinidad, como visión de una globalidad o totalidad tendiente al orden, en la última década adopta una tendencia compositiva que busca la exaltación de la emotividad, el gesto, los cuerpos. En este sentido, también cobra fuerza la estética del detalle, del fragmento, que entendida términos de Calabrese, remite a operaciones de focalización, zoom, descontextualización y re-contextualización del fragmento que eluden el orden para expresar lo caótico, lo casual, el movimiento, lo excepcional de lo re-presentado desde un modelo de visión más identificado con el barroco y con el tono de una "era neo-barroco" (Jay, 1988; Calabrese, 1994) $)^{164}$.

De esta manera, también el seno de la producción iconográfica ligada a los medios masivos, aparece frente a esa tendencia de perspectiva más panorámica y de vista general que realza las multitudes de forma descriptiva y contemplativa otra forma de ordenación estructural: la que gira en torno a la exacerbación de los sentimientos de los sujetos en acción y en primer plano.

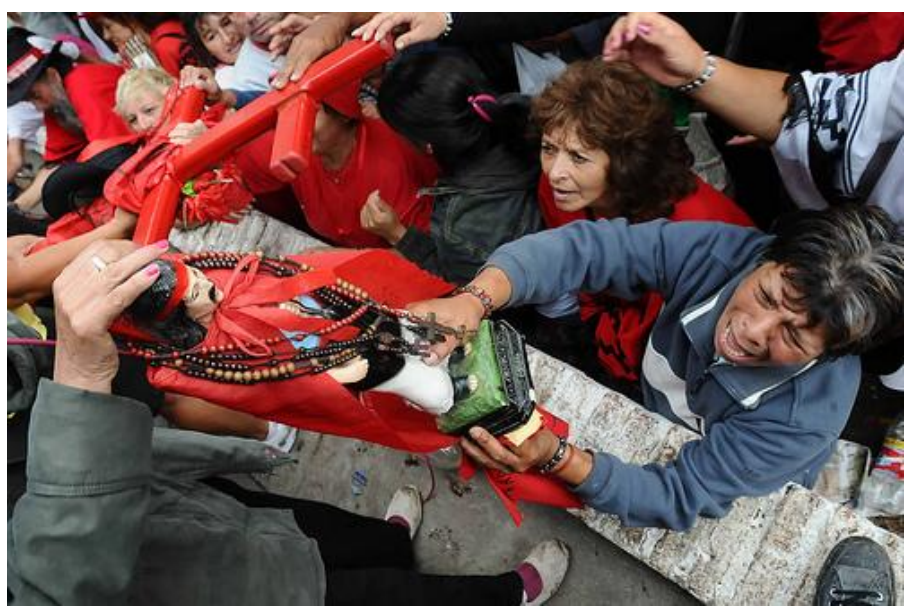

Juan Pablo Faccioli. Sin título. Mercedes, Corrientes, 2008. Publicado el 8/1/2008 en Agencia Corrientes.

\footnotetext{
${ }^{164}$ Cabe recalcar al respecto, que también estos modos de ver están influenciados por la tecnología fotográfica que acompaña la forma de visión de cada época, los cambios de percepción y de gusto. Las cámaras utilizadas a fines del siglo XIX y principios del XX eran aparatos pesados que requerían el anclaje en un punto de vista y mayor tiempo de exposición, condicionando el estatismo de la toma y la predilección por las panorámicas y el retrato de estudio, lo que luego varía con la llegada de las cámaras livianas, dando lugar a nuevas posibilidades de captura.
} 
El fotoperiodismo, en general, y la fotografía latinoamericana, en particular -incluida la foto artística y/o documental-, se presentan actualmente como espacios atravesados por la matriz de la imaginación teatral, la narrativa melodramática y barroca. Son capturas centradas en la expresividad de los detalles de alguna dimensión de los objetos, las ciudades, los pueblos, las prácticas culturales retratados; así como en los personajes, los rostros que representan el drama y la euforia de la vida cotidiana de los márgenes.

En esta línea, podrían enmarcarse las miradas de la festividad del Gaucho Gil de Juan Pablo Faccioli y Guillermo Rusconi, sobre todo aquellas que siguen intereses personales más que las demandas mediáticas. En esas producciones se ponen de relieve el rol del peregrino o participante de la festividad más que la jerarquía de los rituales en sí, el dramatismo y las ráfagas de intimidad devocional.

\begin{abstract}
"Y si miramos un poco estas producciones en Mercedes vemos que primero íbamos con cámara directa retratando escenas donde el protagonista era el rito en torno al Gaucho Gil y la cantidad, el amontonamiento de gente. Pero para los últimos años el fin era buscar más el dramatismo y darle el protagonismo al peregrino. Era una búsqueda más de lo individual que de lo colectivo" (Faccioli, 2012)
\end{abstract}

En esa búsqueda se incluyen fugaces pero significativos momentos de encuentro de muy corta distancia, cara a cara con los fotografiados. Desde esos lugares los fotógrafos se valen de las potencialidades de la carga emotiva del retrato. A menor distancia del objetivo, las tomas se ven invadidas por la expresividad y cada imagen se concibe guiada por el afecto que desborda en el primer plano. Las capturas se centran en los rostros y los cuerpos de los fieles y participantes que dejan de manifiesto sus cualidades afectivas en plena conexión/acción con las iconografías de la divinidad.

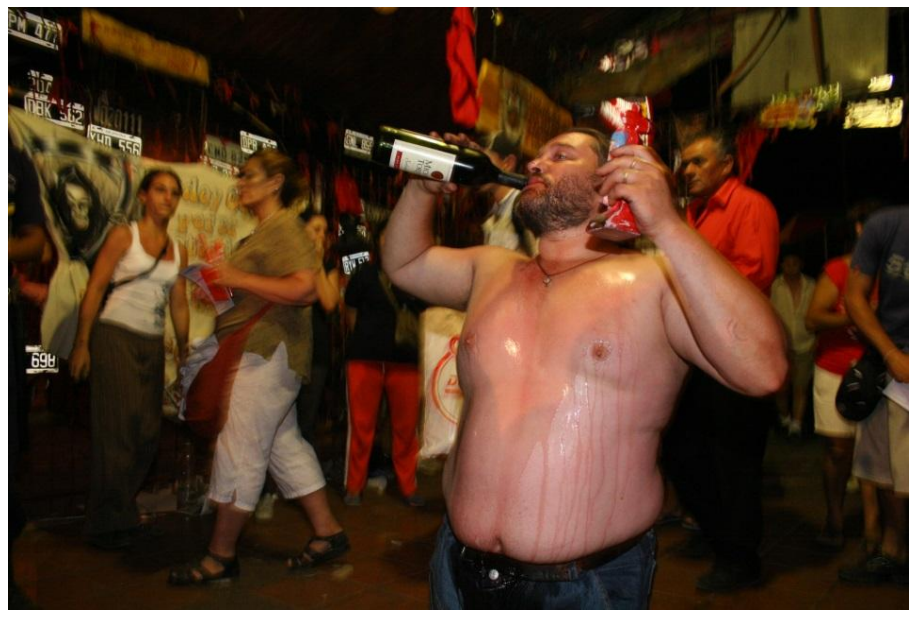

Guillermo Rusconi. Sin título. Mercedes, Corrientes, 2008. Expuesta en la muestra de la Asociación de 
Reporteros Gráficos de la República Argentina, Palais de Glace, Buenos Aires. 2009.

En este sentido la estética melodramática de alguna manera sirve para distinguir a cada uno de los sujetos que hacen a la conmemoración. Permite visibilizar sus pasiones, deseos, estados de crisis y lamentos; así como los elementos más barrocos (eróticos, dramáticos, festivos y hasta grotescos) distintivos de este tipo de prácticas, donde se destaca además una estrecha relación emotiva de los devotos con el santo ${ }^{165}$.

$\mathrm{Al}$ respecto, cabe señalar que si bien es importante el aporte que el ingreso a escena de estas representaciones de primer plano, afectadas y melodramáticas hacen a la mostración y difusión de las heterogeneidades y a simbolizar presencias negadas por la religión dominante, cabría preguntarse aquí hasta qué punto y en qué circunstancias y ámbitos de circulación la estética del melodrama posibilita siempre visibilizar sensible y críticamente lo popular desde lo masivo. Ello porque en los últimos años su retórica de impacto se ha constituido en un esquema estratégico fagocitado por las lógicas mercantiles de los medios para alimentar "la cultura de la conmoción" (Sontag, 2003) y el gusto recurrente por lo raro y lo exótico. En este sentido, la retórica del melodrama fotográfico presenta una contribución dilemática. Por un lado, anida en su configuración la capacidad de afectar, conmover al espectador y guiarlo a la acción o a la toma de una posición en torno a ciertos temas, problemas, acontecimientos postergados; pero por el otro, abona la hipervisibilización o sobre-representación de los mismos recurriendo a repetidas recetas de fuerte impacto que terminan provocando el efecto contrario: la indiferencia.

Esto es a lo que Rancière llama "el poder anestésico de la imagen" que se opone a la capacidad de comprender y de actuar (Rancière, 2010: 103) y que en el campo de la temática de interés contribuye al fenómeno de espectacularización mediática exotizante de la diferencia, que muchas veces termina con el lamentable corolario de la banalización de los rituales reducidos a mera ficción y entretenimiento.

Es por ello que saliendo y entrando de estos esquemas sobreimpresos (el de las miradas panorámicas que tienden a exaltar la magnificencia de las fiestas y la jerarquización de los rituales al modo de la directriz eclesiástica y el de la retórica del melodrama y el fotoperiodismo afectado) rescatamos aquí de las búsquedas de Faccioli y Rusconi miradas tendientes a proponer constantemente otras formas de mirar y representar el complejo universo de la festividad del Gaucho Gil.

165 El Capítulo 6 se detiene en abordar específicamente la configuración melodramática de las imágenes tomadas por Faccioli y Rusconi en la festividad del Gaucho Gil. 
Hablamos de propuestas visuales que se dan no por fuera, sino por dentro de esos esquemas estratégicos de representación tendiendo a subvertirlos con nuevos modos de ver que se divulgan, sino ingresan a las páginas de los medios tradicionales, a través de medios de comunicación alternativos, redes sociales u espacios expositivos.

Es así que entre los retratos, los primeros planos o recortes, también se divisan en las producciones de Faccioli y Rusconi sobre la festividad tomas de planos generales cortos o de conjunto que buscan captar la densidad de la atmósfera socio-cultural, la intimidad devocional, las condiciones de vida y las prácticas identitarias de los participantes, desde las cuáles éstos marcan el territorio de la fiesta y se apropian del mismo.

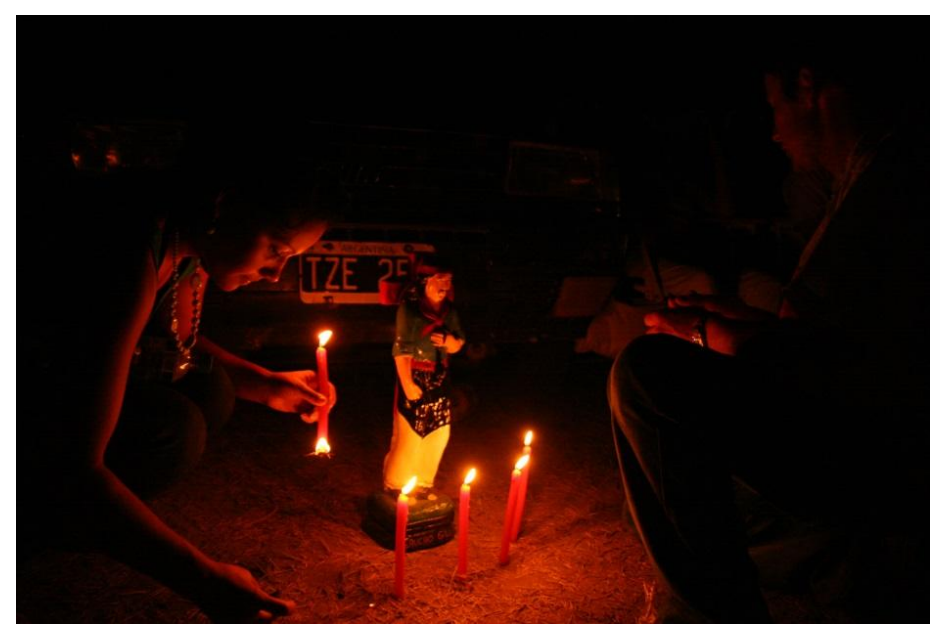

Guillermo Rusconi. Sin título. Mercedes, Corrientes, 2008. Flikr del fotógrafo.

Las propuestas se alejan del esquema de alto impacto, de conmoción violenta o espectacularizante para diseñar con los elementos de los bordes de la festividad una poética de indagación cuidadosa, más atenta a lo que el paisaje cultural presenta, menos especulativa o calculadora en torno a los intereses de mercado y de ventas. Se deja de lado, al menos por instantes el "yo sé qué imagen voy a buscar" para dejarse sorprender por la imagen imprevista con la que lente y el ojo se topa. Esto remite a la tarea de quien investiga, busca, experimenta y ensaya anteponiendo como dice Rancière cierta "distancia y misterio". Asimismo "atención, y curiosidad como afectos que nublan las falsas evidencias de los esquemas estratégicos; son dispositivos del cuerpo y del espíritu en los que el ojo no sabe por anticipado lo que ve ni el pensamiento lo que debe hacer con ello" (Rancière, 2010: 104).

En esa práctica por ejemplo Rusconi abre la cortina y observa que se despliega una bandera roja con la iconografía del Gaucho Gil en la cruz estampada en el medio y la captura atravesando un terreno descampado. Esta imagen no presenta una estructura de ordenación 
con los elementos simbólicos típicos de las primeras fotografías que comenzaron a circular con fuerza a través de la prensa a fines de los ochenta y principios de los noventa haciendo referencia a la festividad (un santuario con carpas a sus márgenes con banderas y pancartas rojas implantadas y decenas de fieles a su alrededor intentando llegar a la imagen del gaucho milagroso para pedir y agradecer). La configuración de esta imagen, que claramente sigue una estética del fragmento (Calabrese, 1994), produce un desplazamiento de la mirada y alude a un emblema o símbolo pero no es sólo eso, es éste fuertemente ligado al repertorio de la territorialidad y el paisaje de la llanura mercedeña, del paiubre correntino.

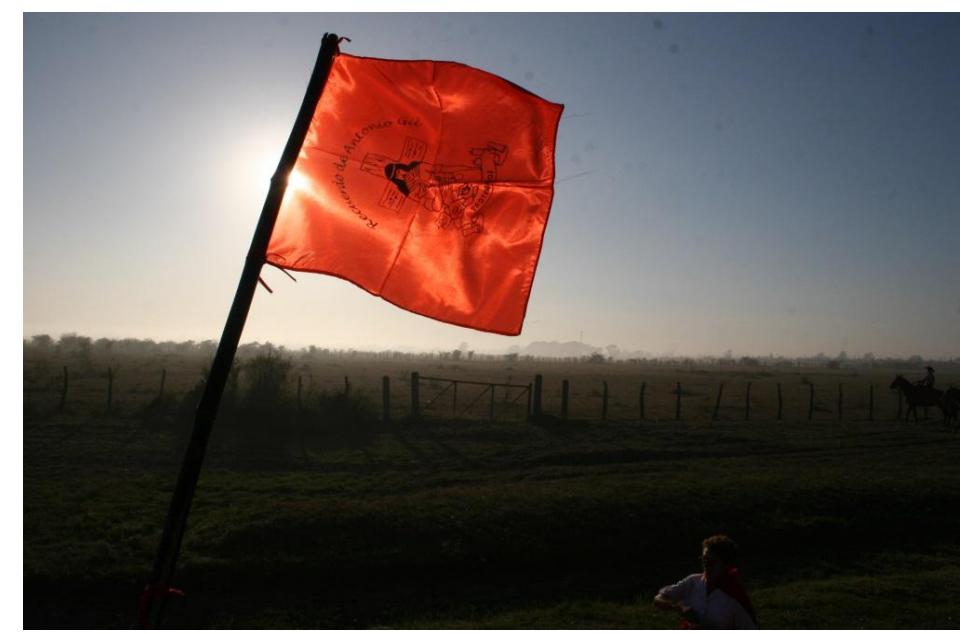

S/T. Guillermo Rusconi. Mercedes, Corrientes, 2011. Flickr del fotógrafo.

En esa búsqueda también Rusconi devela ante su objetivo el cuerpo de una mujer totalmente vestida de rojo emplazada en medio de la ruta divisando alguna cosa, algo, alguien, o sólo esperando, pensando, sintiendo, con la mano derecha que sostiene su sombrero aprisionado a su pecho. Ese cuerpo, esa mujer, se ve inmersa en el paisaje y a su vez se distingue de él, o lo distingue a él.

Esta imagen, como otras, revela la búsqueda de captar la "atmósfera" que revela Rusconi en la entrevista y enseña que el foco de atención puede estar puesto allí donde no se produce el ritual central, donde no está el santuario, el ícono del Gaucho y su cruz, pero que sin embargo no por ello esa deja de dar a ver, aunque de forma distinta, hasta más intuitiva, la intensidad sentida de la conmemoración. 


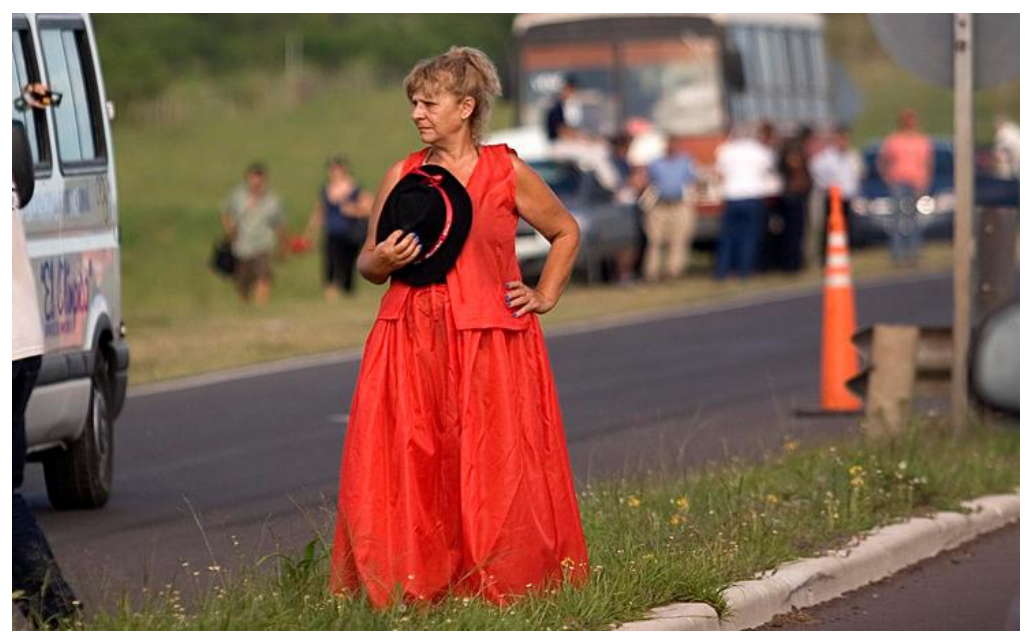

S/T. Guillermo Rusconi. Mercedes, Corrientes, 2011. Flickr del fotógrafo.

\section{De la exaltación de la fe en los cuerpos a la focalización en capas de la memoria}

Así como los descentramientos de las miradas en las prácticas de fotografiar de los autores analizados implica el distanciamiento, el quiebre, la fisura de los esquemas de composición eclesiástica -que fue reproducida, interpelando el mantenimiento de las jerarquías rituales y de poder, en los medios masivos de comunicación (diarios gráfícos, revistas, medios digitales)- estos corrimientos también suponen reconfiguraciones en los modos de concebir las prácticas religiosas en sí. Ello se evidencia en la estética propia del melodrama (con sus alcances y limitaciones), las capturas de la intimidad devocional, los cuerpos en acción y la atmósfera cultural.

En este marco, también puede leerse el trabajo de Eduardo Longoni que realza en su interpretación de la festividad del Gauchito, su carácter de práctica ritual diferencial. La concibe en tanto religiosidad regida por una "lógica otra", en términos de Semán, donde el carácter fotogénico está dado por una especie de fiesta "infernal", como plantea Rivera Cusicanqui (2010) para referirse a las imágenes de las fiestas rituales del mundo andino. Allí todo es movimiento y la expresividad está en la gente, en los cuerpos, el gesto, el exceso de rojo saturado, de velas, de ofrendas, de calor y sudor, de amontonamiento; desenfreno de comida y bebida, de re-producción ilimitada de imágenes veneradas y venerables, de instauración de un modo informal de relaciones con lo sagrado que está "más allá" de los modelos dogmáticos, ordenados, encorsetados, normados de las conmemoraciones religiosas católicas tradicionales.

Como el propio Longoni plantea en la introducción de su ensayo pensado para la 
difusión en la web a través de un e-book, el Gauchito Gil implica:

\begin{abstract}
"Una fe distinta. No es una fe recatada, es una fe desbordante, brutal. Fraguada en la carne, el sacrificio y el calor insoportable de cada 8 de enero en el santuario rutero de Mercedes, Corrientes. Tatuajes, autos inmemoriales humeando, carpas en medio del barro y figuras del santito pagano de todos los tamaños. Una romería de fe" (Libro Superficies, Eduardo Longoni, 2013).
\end{abstract}

Esa lógica de la euforia festiva, atravesada por los códigos sagrados de la concepción cosmológica, es la que se exhibe en las imágenes de Longoni. En este sentido, por un lado la mirada aquí se centra en los bordes y desbordes, en la saturación barroca de elementos, de colores estridentes y la heterogeneidad manifiesta de elementos provenientes de diferentes tradiciones disímiles co-participantes en la fiesta. El mismo autor indica

\begin{abstract}
"Conviven la fe, el bingo, el chamamé, los tatuajes, el barro, el vino tinto tibio (...) una fe bestial (...) Fraguada en carne, en las parrillas pantagruélicas en medio del barro. En chanchos partidos al medio asándose lentamente. En manos que adoran al santo pagano a pasos de un frustrado parque de diversiones que hizo naufragar la lluvia, y que espera con sus elefantes de calesitas enjaulados, que tanto barro se solidifique para partir a nuevos rumbos" (Superficies, Eduardo Longoni, 2013).
\end{abstract}

Por otra parte, la mirada del autor se focaliza en la identidad trazada en los cuerpos. El cuerpo, uno de los grandes temas de la fotografía universal, aparece en la obra de Longoni como el eje vertebral de un modo de ser y de relación. "Gauchito Gil. La fe en la piel”, como se denomina el ensayo de una decena de imágenes expuestas en el libro digital Superficies, se presenta en un estado exacerbación visceral ${ }^{166}$.

El hecho que buena parte del ensayo focalice en los cuerpos tatuados o en cuerpos vestidos pero no para cualquier ocasión, especialmente ataviados, no es una elección inocente. Estos cuerpos se construyen en las fotografías como mapas identitarios donde los unos en relación a los otros manifiestan su condición; como textos o campos de batalla cultural donde se debaten modos de ser, proyecciones de imágenes de identidad.

${ }^{166}$ Disponible en: http://www.eduardolongoni.com.ar/galeria.php?pag=6508 


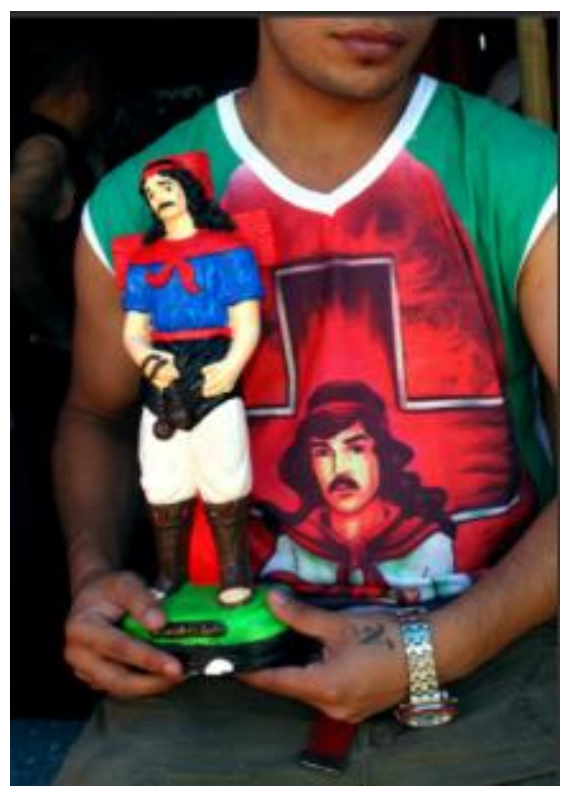

Eduardo Longoni. Ensayo. La Fe en la Piel. 2013

Particularmente, el caso de los cuerpos tatuados remonta a una forma de fe ancestral conectada a las tradiciones de los pueblos indígenas $\mathrm{y}$, a un sustrato ritual de larga data que revela pertenencia, que pervive y prolifera. Ya los primeros cronistas de las Indias advertían el modo en que los nativos se tatuaban sus deidades en la piel. Desde allí la inscripción de la devoción en el cuerpo discute la concepción del tatuaje en términos meramente decorativos para plantearlo como el lugar de la "incorporación", de la "internalización" de un cambio de estado espiritual que se manifiesta en la huella física y visible (Taylor, 2012). Ejemplo de ello es la conversión o la confirmación de la creencia que se descubre como testimonio pero también como canal vinculación, de comunicación con lo sagrado.

Entonces, la utilización del tatuaje que se visibiliza en varios de los recortes de este fotógrafo en primer plano, y en una exploración del placer de mostrar a través del detalle y el fragmento, plantea, a su vez, la puesta en escena del el pensamiento mágico-religioso. Ello vuelve a re-presentar un juego de contraste y ruptura con la moral cristiana en el sentido que la práctica del tatuaje ya en los orígenes del Cristianismo había sido desterrada por considerarla sinónimo de idolatría y superstición que alteraba la imagen del hombre hecho “imagen y semejanza de Dios".

En ese sentido, pueden leerse también los modos en que la exaltación de la fiesta desenfrenada de comida, bebida, baile y el derroche de emociones que actualizan las imágenes. Estas representaciones interpelan a pensar en lo que Rivera Cusicanqui denomina "múltiples transiciones que nos permiten vencer las superficies de la opresión y plasmar 
formas culturales y cotidianas de la rebeldía" (Rivera Cusicanqui, 2010: 136). En otras palabras, nos invita a pensar, en términos de las tácticas de resistencia de las culturas populares que describe De Certeau (2000), cómo en el medio de la dominación y expansión del culto católico en las prácticas de religiosidad popular del Gaucho Gil también se tejen formas de inscripción y re-creación de creencias populares que se contraponen al orden dogmático. Al decir de Rivera Cusicanqui "así se erigen, en medio de la dominación, tácticas subalternas que la transfiguran por medio de signos y prácticas capaces de resignificar la existencia perdida o eclipsada" (Rivera Cusicanqui, 2010: 136).

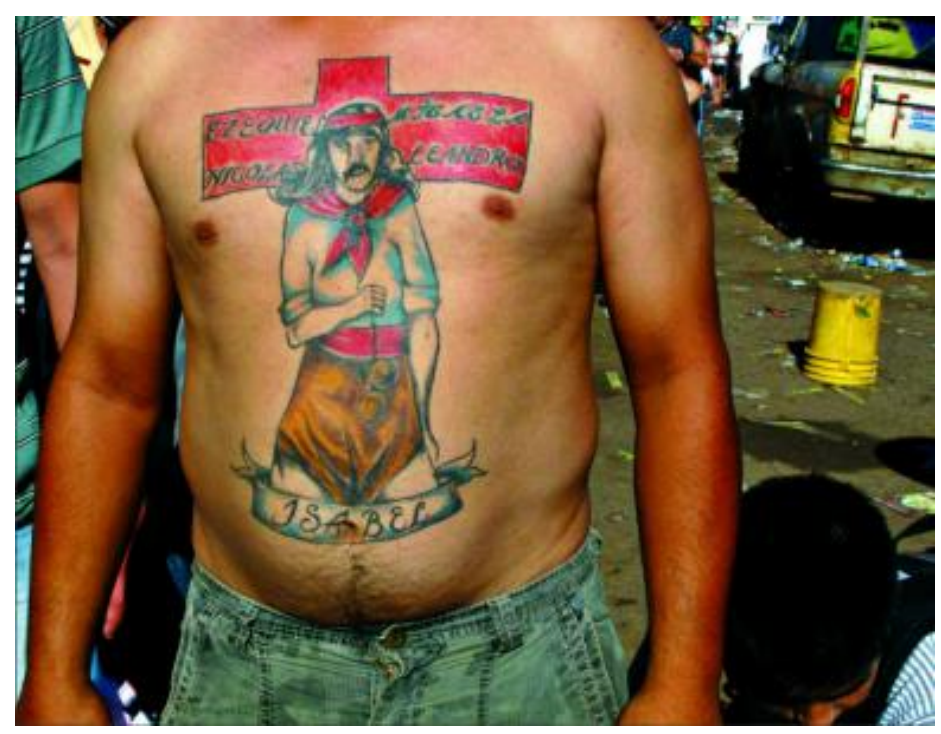

Eduardo Longoni. Ensayo. La Fe en la Piel. 2013

Por su parte, la fotógrafa platense Estela Izuel también bucea por las diversas capas semánticas de esta festividad. Sin embargo, su mirada se descentra de aquello sobre-expuesto, de aquellas imágenes atrapantes de la propia puesta en escena del ritual que asaltan y azotan la visión de cualquier visitante al santuario de Antonio Gil.

Izuel se va alejar del retrato de las personas y los cuerpos en acción para optar por un detenimiento controlado - lo que plantea un trabajo de largas exposiciones en la toma en algunos casos- en los exvotos y en fragmentos de grandes superficies significantes observadas a través de un zoom. Aparecen así objetos, paredes del santuario mercedeño que dejan ver sucesivas capas de inscripciones; cortinas y estantes de los stands de recuerdos atiborrados de objetos, de cintas, de bultos de santos, rosarios que se superponen y se sobreimprimen como retazos densos, espesos de memoria en cada fotografía. 


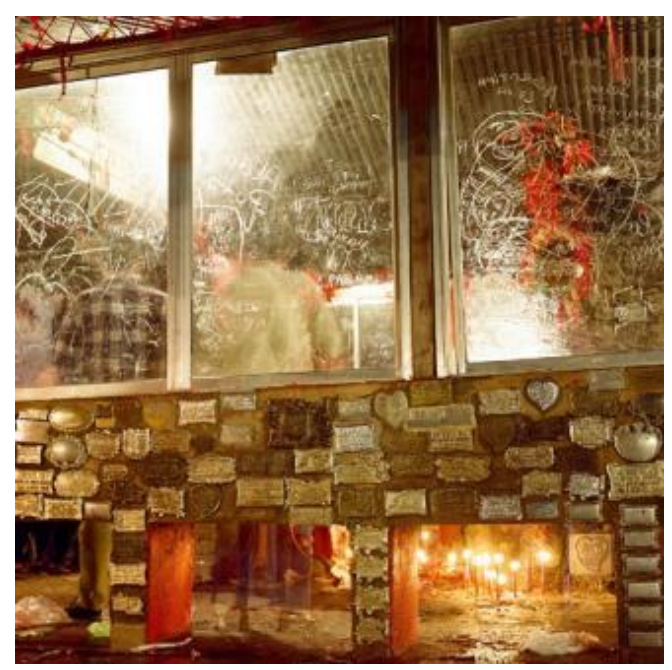

Estela Izuel. Ensayo. Gauchito Gil. 1999

A estos trabajos Izuel llega por una producción financiada por una beca de la Fundación Antorchas que la lleva entre 1997 y 1999 a recorrer por varios meses santuarios y capillitas populares de todo el país. En una reciente entrevista, la fotógrafa comenta cómo lo primero que le llamó la atención fueron aquellos montículos de piedras, cintas, banderas que configuran algunas capillitas, muchas de ellas aisladas en caminos desolados de diferentes puntos de la geografía argentina, como el propio Sur patagónico.

Las primeras experiencias fotográficas tuvieron como resultado capturas en blanco y negro y encierran la mirada del foráneo que se asoma al misterio. Esas imágenes, en su mayoría en planos generales, plantean una particular estética que relaciona la nostalgia, la memoria y el misterio; así como manifiesta la belleza de lo distante y desconocido.

Luego en el mismo devenir de las imágenes se evidencia cómo la mirada de la fotógrafa ingresa en los mundos de las capillitas, de los devotos, de los promesantes, que son quienes les van contando las historias que ellos esconden y la introducen a ese mundo, así llega al Gauchito donde también la estética se detendrá más en el recorte y en la exacerbación del tono rojo. Al respecto Izuel recuerda:

\footnotetext{
"Este trabajo surgió hace mucho tiempo, durante un viaje a la Patagonia, donde me llamaba la atención las capillitas, no sabía de qué se trataba. En ese marco, vi una de las capillitas que era roja en medio de la estepa patagónica y luego supe que era del Gauchito Gil. A partir de allí empecé a buscar, a investigar, preguntar. En esa época había poca información en internet, pero sí a veces en diarios y muchas veces me contaban historias, entonces iba a los lugares de esas historias..." (Izuel, 2015, en Escribir con $\mathrm{Luz}^{167}$ ).
}

\footnotetext{
${ }^{167}$ Escribir con luz es un programa de televisión realizado para la señal Conexión Educativa. La entrevista completa puede verse en: https://vimeo.com/120690240
} 
De la serie de santuarios populares, cuando a la fotógrafa le preguntan, qué obra erigiría que la represente. Pese a la dificultad, destaca "Capilla de la Difunta Correa, 1999” y al respecto comenta:

"Representa un plano, una pared que deja ver sucesivas capas de materiales: hollín, tiza, esgrafiado, una imagen suspendida, capas de textos, y a la vez capas del tiempo transcurrido. Forma parte del trabajo sobre santuarios populares. Descubrí la capillita cuando atravesaba un paraje desolado. Su aspecto exterior era similar al de un horno de barro grande; su interior, oscuro, estaba repleto de imágenes, ofrendas diversas, botellas con agua y muchas velas derretidas" 168 .

Es interesante la cita porque marca gran parte de la propuesta que luego Izuel desarrolla en caso del Gauchito Gil. La mayoría de las imágenes en el santuario se plantean como palimpsestos de la memoria, aquellos que en términos de Martin-Barbero remiten a "un tipo de identidad que desafía tanto nuestra percepción adulta como nuestros cuadros de racionalidad, y que se asemeja a ese texto en que un pasado borrado emerge tenazmente, aunque borroso, en las entrelíneas que escriben el presente" (Martin-Barbero, 2002). Lo que también remite a una identidad densa, hecha de capas con inscripciones con intenciones y orientaciones heterogéneas, al modo de las paredes de Izuel, también precaria y frágil que tiende a abrirse a nuevas sobreimpresiones con el devenir del tiempo. Ello habla en parte de la dinámica del sentido y la dinámica de la densa memoria de cada uno de los detalles que configuran el mundo del Gaucho Gil recreados en la fotografía.

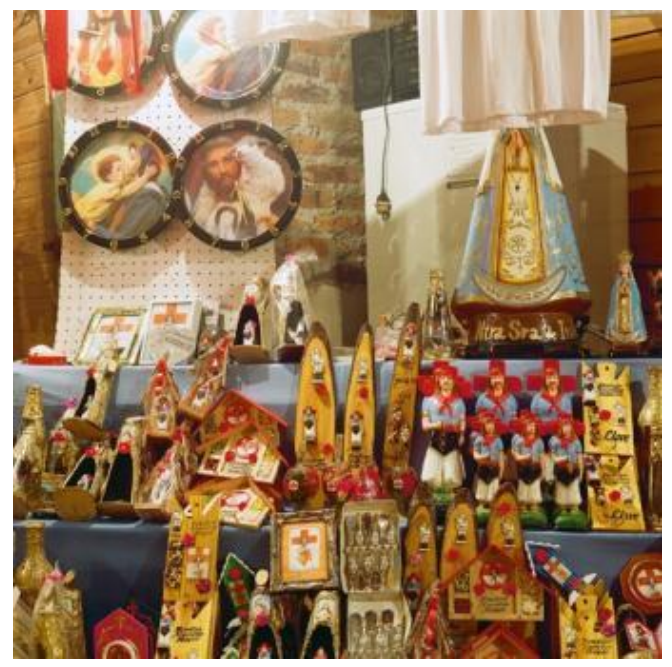

Estela Izuel. Ensayo. Gauchito Gil y la virgen. 1999

${ }^{168}$ Referencia disponible en: http://www.boladenieve.org.ar/vision/473 


\section{Del reino del index a la fuerza de la simbolización en el artificio}

La trayectoria de documentación fotográfica de los santuarios populares argentinos que Estela Izuel experimenta, visibilizando los microcosmos de los exvotos y las múltiples capas de la memoria que se sobreimprimen en paredes, muros, superficies diversas, como planos de estos universos mágico-religiosos, desembocan en una mirada atenta del mundo del Gaucho Gil. En este marco, cada inscripción, objeto de recorte actualizado en la mirada fotográfica va construyendo un itinerario simbólico de la devoción con un alto contenido visual y también emocional.

En este sentido, las últimas imágenes de la misma serie (Gauchito Gil) -que puede verse completa en la página web de la fotógrafa ${ }^{169}$ - van a dar cuenta de un proceso de mayor abstracción que llega incluso a un despojo de referencia explícita de la festividad (ya no aparecen indicadores referenciales de éste o aquel santuario, tiempo, devoto, etc) para exaltar la cualidad de determinados objetos y detalles.

Luego, Izuel descontextualiza esos fragmentos de textos visuales de alto contenido simbólico, los aísla y los lleva a su estudio fotográfico para plantear foto-instalaciones que subvierten el registro documental e interpela a reflexionar en torno estas fotos, más allá del valor de testigo del que estuvo ahí para capturar un fragmento de lo acontecido. Es decir, pensar su valor conceptual y su condición de "imagen híbrida", en términos de González Flores (2005), en tanto conjuga la utilización del medio fotográfico, la instalación, el ready made y el indudable gesto pictórico en la producción visual conceptual.

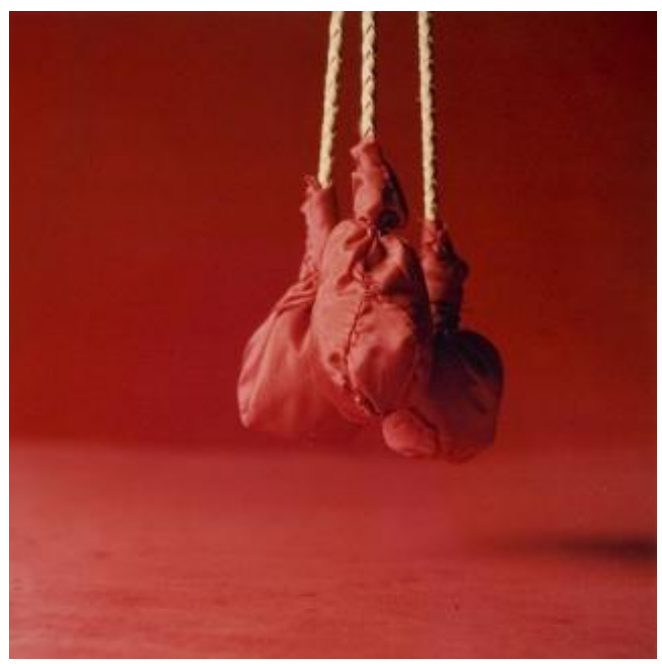

Estela Izuel. Ensayo. Gauchito Gil. 1999

${ }^{169}$ Link: http://www.estelaizuel.com/ 
La vieja discusión sobre los límites para definir el valor testimonial, documental y de creación de la fotografía, atendiendo los grados de mayor alteración de lo real en la producción, aquí queda descartada. La fotografía Estela Izuel, como la de Marcos López, sobre la que nos detenemos más adelante, se redefinen contrapuestas a las intenciones de los ensayos foto-periodísticos y documentales dominantes en los casos anteriores porque se despojan de la necesidad de estar en el lugar de los acontecimientos y sujetos a la captación del "momento decisivo" en el que insistiera Robert Capa para lanzarse con libertad a la construcción de la imagen. Y lo hacen a partir de la puesta en escena deliberada y sin culpas, de la apuesta a la interrelación de medios, al juego y aprovechamiento de las potencialidades de la instancia de posproducción.

Estas expresiones se volverán claramente hijas de la era de la posfotografía anunciada por Fontcuberta (2010). En ese marco, como señala Dubois (2008), si bien la foto es antes que nada huella física de la presencia (índex) también se vuelve un "dato icónico, bruto, manipulable" como cualquier otra sustancia concreta. Por lo tanto, allí reside su capacidad para combinarse, integrarse, interrelacionarse a otros materiales y medios para la conformación de la obra. De este modo, la fotografía contemporánea adquiere también aquel carácter complejo del ensemble que Lotman (1996) pensó para nominar a la combinación de lenguajes y traducciones intra e inter textuales que conviven en el cine y el teatro y donde también la noción de "autor" queda relativizada. El testimonio de Marcos López es contundente en este sentido:

\begin{abstract}
Mis fotos llevan una posproducción digital donde la actitud es totalmente pictórica y, al mismo tiempo, teatral, porque armo una puesta en escena y, a veces, ni siquiera soy quien hace el click. Muchas veces contrato un fotógrafo y me dedico a armar la puesta. Funciono como un director de cine o de teatro que hace una escenografía para su puesta en escena. Todo esto es un buen ejercicio para relativizar la idea del autor, del ego, de la obra por encargo (López en El cronista, 26-01-2012 ${ }^{170}$ ).
\end{abstract}

Particularmente, en el trayecto de la producción de López observamos un pasaje de los retratos documentales en blanco y negro de personajes y escenas familiares a su Santa $\mathrm{Fe}$ natal, hacia en una imaginación iconográfica de Latinoamérica a partir del conjunto de obras que denomina Pop Latino (caracterizado por colores estridentes, la puesta teatral, publicitaria, la explotación de íconos bizarros, las marcas, los carteles, el plástico, el sarcasmo y la parodia) y luego la imaginación de la Argentina de la periferia en la serie Subrrealismo criollo con la mirada enfocada en el color local, en los tipos y estereotipos identitarios

170 Referencia disponible en: http://www.cronista.com/claseejecutiva/Soy-el-hijo-ilegitimo-de-Warhol20120126-0138.html 
argentinos que no abandonan la reminiscencia constante a lo que él denomina "textura emocional de los recuerdos" de la infancia, de los miedos, de los deseos. Al respecto en una entrevista López comenta:

“(...) siempre vuelvo a ese joven de provincia, educado en colegio de curas con cierta represión. Por momentos -afirma- mi obra, que es provocadora, barroca, es resultado de ese niño interno, educado en un mundo conservador, que quiere transgredir, jugando con el miedo y la culpa" (López, en El Telégrafo, 20/07/2015 171 )

Así, entre la referencia a la desigualdad social en América Latina, a partir de la construcción retórica que apuesta a la exacerbación de la violencia de los colores y sus contrastes como metáfora de lo barroco y lo heterogéneo propiamente latino ${ }^{172}$, y la remisión a la Argentina como el "país de cartón pintado" de los años 90 en alusión, ya sea en forma de sátira o parodia, al modelo neoliberal argentino y a la "degradación de las culturas locales" en los márgenes del "mundo global"173, aparecen en la obra de López las figuras de los santos populares junto a héroes históricos y líderes populares del siglo XX. Si bien, estas imágenes son preponderantes en obras de los años 2000 donde López explora mitos y santos populares de Latinoamérica en obras como "Mitos y Santos", Venezuela 2006, o "Suite Bolivariana", Buenos Aires 2009; ya en los años 90, la figura del Gaucho Gil se entremezcla en los santuarios que López re-crea para dar cuenta del campo religioso argentino diversificado, como porción de la Latinoamérica mestiza. Todo ello inserto en lo que él mismo concibe como la exploración constante de la "poética de la periferia", la "textura del subdesarrollo" $" 174$.

Por otra parte, la figura del "santo" popular cobra una fuerza singular en el retrato “Gaucho Gil”, Buenos Aires 2008. La fotografía se ubica junto a las obras paradigmáticas del artista signadas por las estrategias de citas y apropiaciones en la construcción visual. Entre ellas, se puede citar “Asado en Mediolaza” del año 2001 que remite a la emblemática "Última Cena" de Da Vinci para recrear un ritual de asado de domingo entre amigos; una obra

171 Referencia disponible en: http://www.telegrafo.com.ec/cultura1/item/la-melancolia-compone-el-arte-demarcos-lopez.html

${ }^{172}$ Al respecto, Valeria González quien realiza una reflexión sobre las diversas etapas de producción del artista resalta que "la "latinidad de su propuesta deriva directamente de la voluntad de relativizar las pretensiones de toda estética regionalista en el panorama de devaluación actual de las culturas periféricas. Su obra emerge de un potente cuestionamiento de la fotografía de ejecución correcta, acento sentimental e iconografía autóctona que el sistema del arte internacional ha tipificado como paradigma de la producción latinoamericana" (González, 2010). ${ }^{173}$ Ver González (2010)

174 Para López esa "es la poética con chancletas de Taiwan y piletas de pelopincho. Espejitos de colores y teléfonos celulares en un país de cartón pintado (...) una reflexión sobre la identidad emocional" (Entrevista, La Gaceta, 2013). Textura que Castellote interpreta como aquella que "convierte en símbolo de una sociedad que a menudo ha basado su identidad en los referentes prestados por las culturas centrales" (Castellote, 2010). 
considerada emblemática dentro de la fotografía latinoamericana contemporánea porque según Castellote "marca la ruptura con el academicismo documental y la sustitución de los mitos por los protagonistas anónimos de la historia" (Castellote, 2010).

En este marco, el retrato de interés, al que referimos en detalle en el apartado siguiente, también esboza una reinvención de la estampita del Gaucho Gil, donde el sentido original de ésta aparece subvertido y con una estética muy emparentada a la de los artistas franceses Pierre et Gilles ${ }^{175}$ (caracterizados por el montaje de complejas escenografías, la construcción de personajes, vestuarios y retoques de la imagen donde también dialogan imágenes paradigmáticas de la historia del arte, temas religiosos, míticos y la cultura popular, la cultura gay, el pop, entre otros).

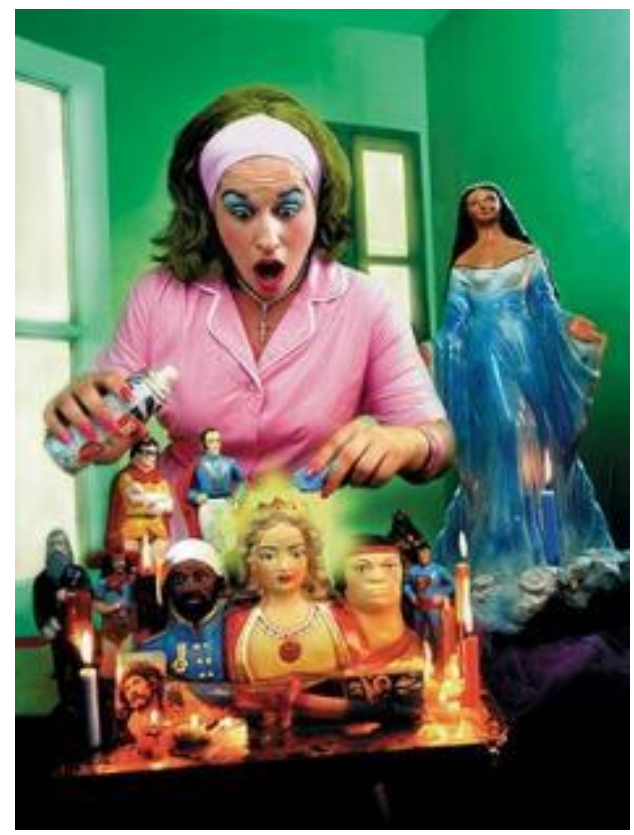

Marcos López. Santuario, Buenos Aires, Argentina, 1998. Pop Latino

En definitiva, el trabajo de Marcos López presenta una trayectoria encaminada a integrar la fotografía a una suerte de amalgama de soportes y a la mixtura de materias hacia un juego de combinaciones simbólicas que en su factura remiten al ensemble de Warhol, asociado al recorte de elementos que se presentan uno tras otro en forma de secuencia; al Pop Art en general por el gusto insistente por la puesta en escena, los estereotipos y la presentación de objetos, cosas de la vida cotidiana; así como a la publicidad con un cuidadoso trabajo de posproducción. Sin acabar allí, López plantea una predilección por el cruce

${ }^{175}$ La referencia es mencionada por el propio López en la entrevista al diario La Gaceta en 2013. Disponible en: http://www.lagaceta.com.ar/nota/570248/espectaculos/marcos-lopez-arte-oficio-hay-sacarle-glamour.html 
constante de los límites entre las artes. Muchas de sus imágenes, incluidas la del Gauchito Gil, se han convertido en una foto-instalación en el montaje de muestras.

Por citar un ejemplo, en el año 2010, montó la exposición denominada "Exceso" en la galería Ruth Benzacar y en ella conjugó una verdadera puesta en escena donde utiliza como soporte la fotografía e introduce con la colaboración de otros artistas pintura, instalación, video y escultura. Allí, la imagen fotográfica adquiere sentido desde la puesta en escena e integrada a un dispositivo que la supera y que configura su capacidad de persuasión. En ese ámbito, el Gauchito Gil de López se plantea beligerante y desde esa posición el fotógrafo reaviva su gesto desafiante, invitando a prenderle velas a un gaucho ya no sumiso como el de las estampitas, sino rebelde.

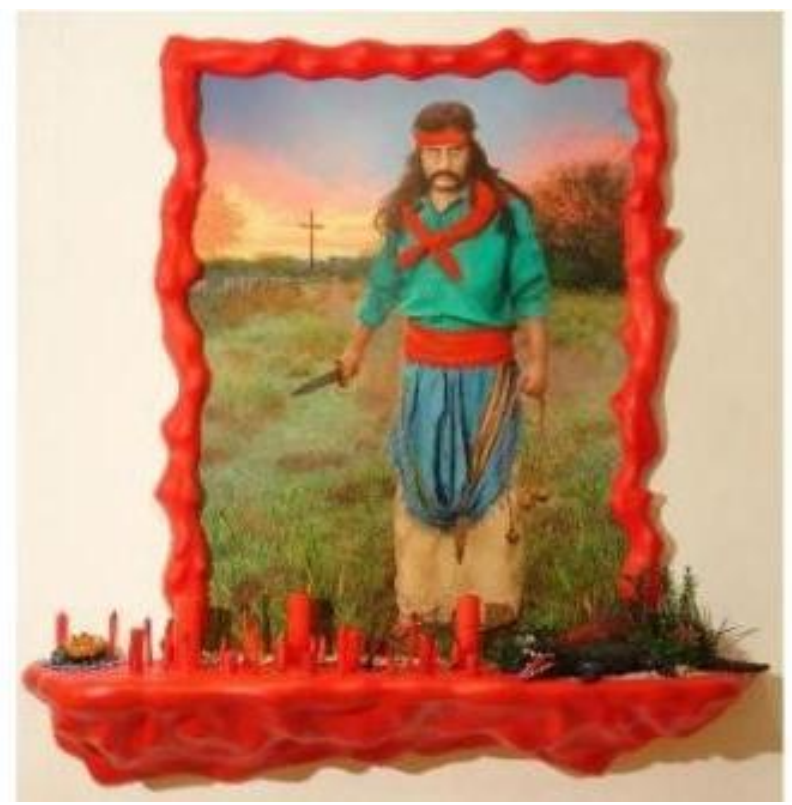

Gauchito Gil. Muestra Exceso, Marcos López, 2010.

\section{La estampita del Gauchito en el juego de las citas y apropiaciones}

En el abordaje de las tramas de memorias y formas de in-visibilidad que configuran el Gauchito iconográfico y fotogénico, al que referimos en el Capítulo 3, ya habíamos advertido sobre el potencial performativo que posee un icono central que referencia la figura del Gaucho Gil a través del bulto escultórico emplazado en el santuario mercedeño y las estampitas del santo que ayudaron a su propagación. Planteamos allí una conjetura que aquí sirve de punto de partida: el potencial performativo de esta iconografía responde no sólo a su cualidad formal -la fuerza intrínseca de la forma, figura y color hechos cuerpo en la imagen 
material visual- que sin lugar a dudas debe atenderse detenidamente, sino también a su constitución históricamente densa, compleja y hasta antagónica en tanto representación que vehiculiza sentidos culturales e ideológicos procedentes de tradiciones disímiles.

Dicha hipótesis, a la luz de la observación detenida de la estampita más difundida del Gaucho Gil, a su vez sometida a estrategias de cita y apropiaciones diversas en la producción fotográfica de los autores analizados, re-instaura en este apartado preguntas muy similares a las que Malosetti Costa se realiza en su texto El poder de las imágenes $\left.{ }^{176}: 1\right)$ cuáles son los mecanismos a partir de los cuales ciertas imágenes logran anclarse y actualizarse permanentemente en la memoria colectiva $\mathrm{y}, 2)$ qué poderes adquieren para reactivarse después de largos períodos en distintas esferas de la cultura, incluso desde la práctica fotográfica y desde allí proliferar y generar informaciones nuevas.

En esta línea de inquietudes, aquí observamos cómo la iconografía central de Gil posee una alta capacidad per-formativa (Bulter, 2001) que no sólo propicia su recreación en y desde la producción misma de los objetos, los cuerpos y las distintas materialidades asociadas a la devoción -que se extienden a la vera mercedeña, en Corrientes, y diversos espacios de los costados de las rutas de todo el país-, sino que también interpela la práctica fotográfica documental y artística.

Desde este lugar, entendemos que esta iconografía posee una potencia visual que opera anclada a una densidad histórica no lineal más bien compleja, que "actúa redoblando la capacidad de la imagen de ser venerada, despertar, sostener y recrear creencias; e incluso intimidar, ser rechazada, temida y hasta destruida" (Malosetti Costa, 2002). Hablamos de una historicidad que ensambla dispositivos y representaciones que remiten a tiempos, memorias y contextos socioculturales diversos.

En este sentido, vale recordar que si bien hablamos de un "santo" popular que no ha nacido amparado por la iglesia oficial y que actualiza rituales y formas de veneración de los muertos vinculados al mundo guaraní, no se puede negar que, como señala María Rosa Lojo, (2007), al menos en parte no deja de ser católico el aparato de difusión que se utiliza para la propagación desde los inicios de la devoción: incluyendo la estampita con la efigie del santo, acompañada de una oración al reverso, flores, velas en santuarios para pedir y agradecer, lo que se enfatiza con distintas estrategias y dispositivos de las industrias culturales. Asimismo, en esa imagen se entrecruzan las referencias a Jesucristo Crucificado, el Curuzú guaraní,

\footnotetext{
${ }^{176}$ Disponible en: http://www.eldiariodeljuicio.com.ar/?q=content/el-poder-de-lasim\%C3\%A1genes-laura$\underline{\text { malosetti-costa }}$
} 
retóricas de la identidad/alteridad nacional que remiten a figuras como el Martin Fierro o Juan Moreira; pero también a la estampa gaucha como representación nodal de la correntinidad ${ }^{177}$.

Lo expuesto manifiesta cómo un imaginario anacrónico pareciera siempre signar la vida de las imágenes. Porque como señala Armand Mattelart "en cada imagen retorna la historia, resuenan constructos pasados (...)" (Mattelart, 2012). Particularmente, la estampita del Gaucho Gil condensa una densa memoria, o más bien, entrelaza diversas memorias que producen reenvíos a símbolos y representaciones nodales cuya de-codificación en la recepción pareciera incidir en sus formas de valoración atravesando diversas instancias de circulación, consumo y re-producción cultural.

Cuando hablamos de símbolos, tales como la cruz de Cristo o la figura del gaucho, entre otros en dicha iconografía entramados, los entendemos en los términos que Iuri Lotman concibe a los "elementos más estables del continuum cultural" (Lotman, 1993: 49). En esta línea, el símbolo es aquel que se vincula a un fragmento de texto arcaico "cuya memoria es más antigua que su entorno textual no simbólico"; es decir, que no pertenece a un solo corte sincrónico de la cultura, sino que lo atraviesa verticalmente, "viniendo del pasado y proyectándose al futuro". Al estar conformado por un plano del contenido que posee una reserva de espacio semiótico factible de ser llenado con un nuevo contenido, el símbolo puede mutar conservando una invariante original, así como "transportar textos de una capa de la cultura a otra" (Lotman, 1993:49). Esta concepción permite explicar la larga vida semiótica y la naturaleza invariante y a la vez variante de los símbolos que aquí exploramos condensados en iconografía del Gaucho Gil. Asimismo, habla de las capacidades de estos signos también de funcionar como "representaciones nodales" (Cebrelli y Arancibia, 2012); es decir, como macrorepresentaciones que propician procesos de adscripciones identitarias ya sea en torno a "lo cristiano", "lo nacional", "lo popular", "lo correntino", entre otros.

Entendemos que dichas condensaciones resumidas en rasgos hipercodificados hacen que la iconografía del gaucho milagroso sea susceptible de ser apropiada en distintas instancias de producción de sentido y pueda ser articulada a diversas cadenas de significaciones. Particularmente, aquí nos interesan esos procesos de producción de sentido donde la práctica fotográfica es atravesada y construida por procesos de apropiación diversas implicando operaciones de cita, referencia, re-iteración en la construcción de la imagen.

Comprendemos a la apropiación, siguiendo a Roger Chartier, como una práctica o acto vinculado a "los usos y las interpretaciones, inscritos en prácticas específicas que las

${ }^{177}$ Sobre estas sobreimpresiones representacionales ahondamos en el Capitulo 3. 
producen y que están atravesados por determinaciones sociales, institucionales y culturales" (Chartier, 1992). Desde esta práctica es posible pensar la producción fotográfica inserta en procesos de producción/circulación/consumo -entendidos como circuitos interdependientes- y de migración de imágenes más amplias. En otras palabras, hablamos de una producción fotográfica integrada a formas de relación, estrategias de préstamos, de intercambio, por parte de los sujetos consumidores-productores de imágenes con objetos y productos de la cultura - ya sea producidos y transmitidos por las industrias culturales u otros agentes que actúan en el campo cultural- a los fines de recuperar, actualizar y re-crear los significados circulantes.

Desde esta perspectiva interesa analizar aquí los casos que plantean la producción de las fotografías "Devoto", de Juan Pablo Faccioli (2008) y el retrato "Gaucho Gil" de Marcos López (2008). Nos detenemos en observar cómo los elementos semánticos, compositivos e incluso los dispositivos que propaga la festividad del gaucho Gil, partiendo de la estampita más difundida del "santo" popular, son apropiados y re-semantizados por/ o "migran" al decir de Dubois (2011) hacia otras imágenes y dispositivos diversos.

\section{5.a)- Entre el Martin Fierro y la encarnación del Gauchito en la foto de Juan}

\section{Pablo Faccioli}

En el caso imagen del devoto del Gaucho Gil retratado por Juan Pablo Faccioli en 8 de enero 2008 en la festividad central de Mercedes, Corrientes, vemos que no sólo el fotografiado, a través de su investidura y su disposición corporal ante la cámara, sino también el fotógrafo, en la elección de ese recorte y no otro en la construcción de la imagen, recurre a/convoca representaciones sociales cristalizadas en la memoria colectiva. Confluyen representaciones formadas por las configuraciones ligadas a la devoción del Gaucho Gil -el retratado es prácticamente la presencia viva de la iconografía más difundida del difunto- y también asociada a narrativas de la nacionalidad argentina- el retratado guarda un gran parecido con imágenes del Martin Fierro y otras figuras de la gauchesca difundidas principalmente por el cine; la semejanza se acentúa sobre todo debido a los elementos de la performance: cierta ropa, peinado, accesorios, gestos, mirada ${ }^{178}-$.

\footnotetext{
${ }^{178}$ Esto se transforma en lo que Belting entiende como el cuerpo comprendido como el arquetipo de las imágenes (Belting, 2007).
} 


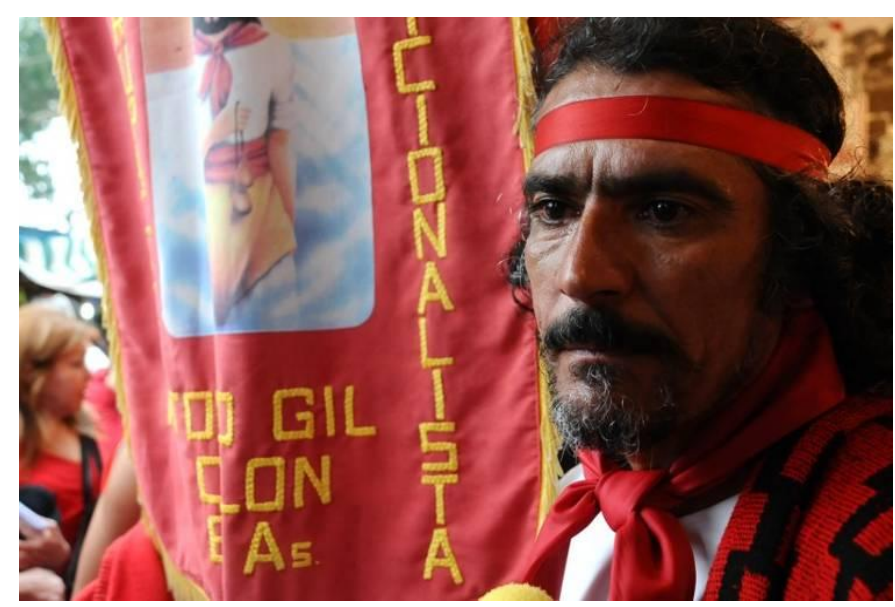

Devoto. Juan Pablo Faccioli. Mercedes Corrientes, 2008.

En primer lugar, es posible advertir que el fotografiado además de volver a presentar lo ausente (Marin, 2009), en este caso al Gauchito Gil -como imagen mixturada/ sobreimpresa a la de Martin Fierro-, también de alguna manera encarna a su referente. Ese proceso de encarnación, que implica la internalización del modelo de la divinidad en el sujeto que vemos, produce como primera impresión en el espectador la pérdida de la noción de estar ante una situación de referencia o semejanza y, más bien, se intensifica la presencia del hombre que se exhibe así mismo cual si fuera la divinidad humanizada. Si bien en este proceso intervienen relaciones complejas entre el cuerpo humano pensado como imagencuerpo modelizado a la luz de una imagen-modelo, que vendría a ser dios o el Gauchito como divinidad, en las que aquí no ahondaremos ${ }^{179}$; podemos resumir que en la escena se manifiesta un devoto que imita a su "santo". Desde ese lugar, el hombre "se diviniza, sustituye a su propia deidad para acercarla a los demás y para mostrar que en él existe y se manifiesta" (Sánchez Montalbán, 2004: 680).

Siguiendo a Sánchez Montalbán, la representación teatral que funciona como simulacro opera en esta escena como factor que justifica la fotografía; pero además, esa presencia intensificada del hombre que se diviniza, se muestra y hasta seduce a la cámara, con la potencia reproductora propia que el prototipo encarnado, produce lo que Marin llama "efecto de sujeto". Es decir, la representación construye al sujeto que la mira, en tanto legitima formas, interpela al observador incidiendo en sus de percepción, valoración y acción. En este caso el fotógrafo no logra eludir la potencia performativa del arquetipo escenificado y lo reproduce en la fotografía sin llegar a problematizarlo.

\footnotetext{
${ }^{179}$ Consultar Jean-Marie Schaeffer (2012). "El cuerpo es imagen", en Arte, objetos, ficción, cuerpo. Cuatro ensayos sobre estética. Biblos: Buenos Aires.
} 
De este modo, podría decirse que hay una construcción "colaborativa" entre fotógrafo y fotografiado ${ }^{180}$ de la imagen fotográfica. Sin embargo, esa acción no es libre, sino que está condicionada por la reproducción de esquemas de representaciones heredados que van atravesando los procesos culturales, que se anclan en la memoria colectiva y se reactivan según las demandas sociales, los regímenes de visibilidad vigentes y las actividades de la memoria- en prácticas rituales y actos fotográficos como este.

En este caso, la escena ritual y la práctica fotográfica apelan a la actualización del estereotipo del gaucho argentino que encuentra su matriz en el Martín Fierro, de José Hernández, texto configurador de una estética y ética del prototipo de lo nacional puesto a circular por diversas narrativas. Entre ellas, se puede citar como caso emblemático el film Martin Fierro, de Torre Nilsson de 1968, que le otorga a la imagen literaria del gaucho una imagen material visual cinematográfica altamente pregnante y que actúa como fragmento sobreimpresos a la literatura fundante del Estado Nación ${ }^{181}$.

Desde la producción fotográfica, dicho estereotipo es una iconografía eficaz para la cita porque al estar parcialmente cristalizada en la memoria colectiva asegura un rápido reconocimiento en el espectador. Recordemos que el gaucho es el símbolo otro de la nacionalidad argentina por excelencia. Como tal condensa entre otros sentidos del hombre excluido identificado con la barbarie, el convertido en "gaucho malo" (El gaucho Martín Fierro de 1872- conocido como La ida) pero también los valores de buen campesino obediente y trabajador, que regresa a la civilización (La vuelta de Martín Fierro de 1879) (Ludmer, 1994).

Particularmente, desde la fotografía de Faccioli, en la que se elige exponer al gaucho devoto junto (casi como extensión de sentido) al estandarte que vehiculiza la imagen del "santo" popular en la cruz, si se lo lee en relación a la leyenda más difundida del Gaucho Gil se podría interpretar en principio como una suerte de prédica de la vuelta del gaucho de La ida de José Hernández pero re-significado en y desde su re-apropiación popular (y) masiva.

\footnotetext{
${ }^{180}$ Respecto a las formas de seducción y construcción colaborativa entre fotógrafo y fotografiado en esta imagen se vuelve en el Capítulo 6.

181 También es relevante en la referencia de la imagen del gaucho, el texto La guerra Gaucha de Leopoldo Lugones y su correlato cinematográfico en la película del mismo nombre de Lucas Demare, de 1945, uno de los hitos del cine argentino que de alguna manera inaugura el camino de la construcción de la figura épica del gaucho en el cine, revisitado por otros directores, entre ellos el propio Nilsson. Sobre la pregnancia de estas representaciones cinematográficas y su rol configurador de formas de percepción y adscripción identitaria en producciones audiovisuales actuales y prácticas culturales cotidianas contemporáneas en general puede leerse Arancibia (2007; 2009) y Giordano, Barrios, Pageau y Gómez Montero, 2014).
} 

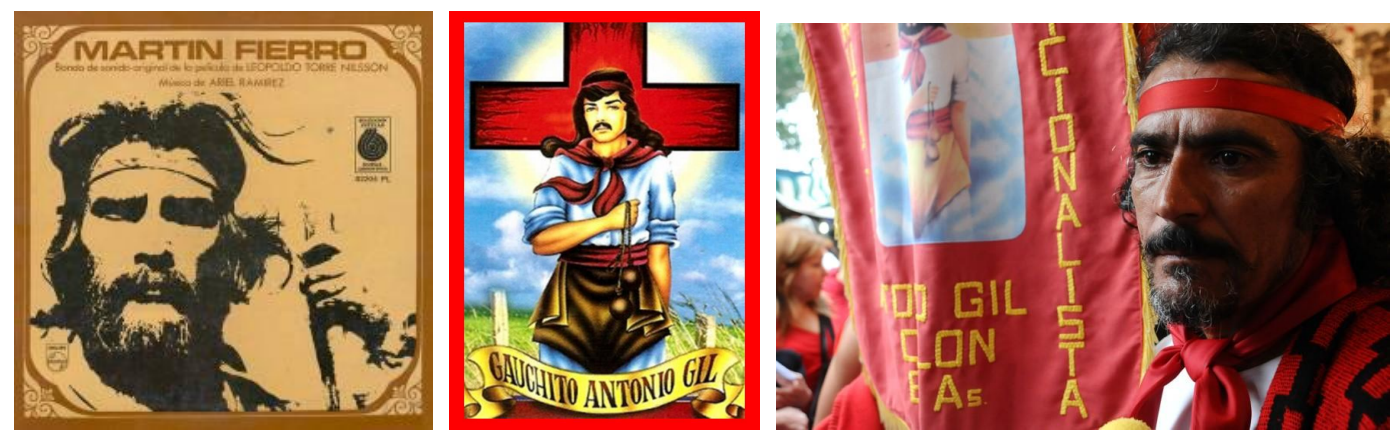

Sobreimpresiones iconográficas. Iconografía del gaucho Martin Fierro en la portada del disco de banda de sonido de la película de Nilsson de 1968/ Estampita del Gauchito Gil/ Devoto de Juan Pablo Faccioli

En la búsqueda de una variante de sentido y ante la presencia tan "compacta" del devoto y su bandera, que justamente por su contundencia se manifiesta reacia "al punzón del concepto" (Escobar, 2013), el fotógrafo recorta en la composición la cabeza del Gauchito Gil de la bandera, visible en el extremo izquierdo de la imagen, para hacer que el espectador busque completar la información en el rostro del devoto, visible en el sector derecho, que se plantea como la figura de la divinidad humanizada.

En este caso la práctica de apropiación fotográfica no de-construye las representaciones cristalizadas que sugiere la puesta del devoto para ponerlo en crisis o cuestionarlo, no realiza una alteración de los signos de los que parte en la construcción de la imagen, sino más bien prolonga esa experiencia de actualización de estereotipos e imitación de la divinidad escenificada. Luego, la fotografía adquiere nuevos sentidos a través de su circulación mediática y espacios de exhibición artística.

En este sentido, vale señalar que la imagen del devoto de Faccioli fue publicada en una agencia de noticias en 2008 (Agencia Corrientes) y a través de ella en diversos medios suscriptos, sobre todo provinciales. Luego, en 2010 la fotografía pasó a formar parte de la muestra itinerante Devoción. Imaginarios de Fe en Corrientes, que se expuso en Mercedes entre diciembre y febrero de 2010-2011 y distintas ciudades del Nordeste.

\section{5. b)- El retorno del gaucho malevo en la fotografía de Marcos López}

Atentos a las condiciones de interpelación antes citadas que hacen que la iconografía del Gaucho Gil, desde la estampita de mayor difusión, haya sido apropiada en distintas instancias de producción de sentidos, interesa aquí indagar en esos procesos vinculados a la práctica fotográfica de Marcos López y específicamente su propuesta con el retrato Gaucho Gil de 2008 . 


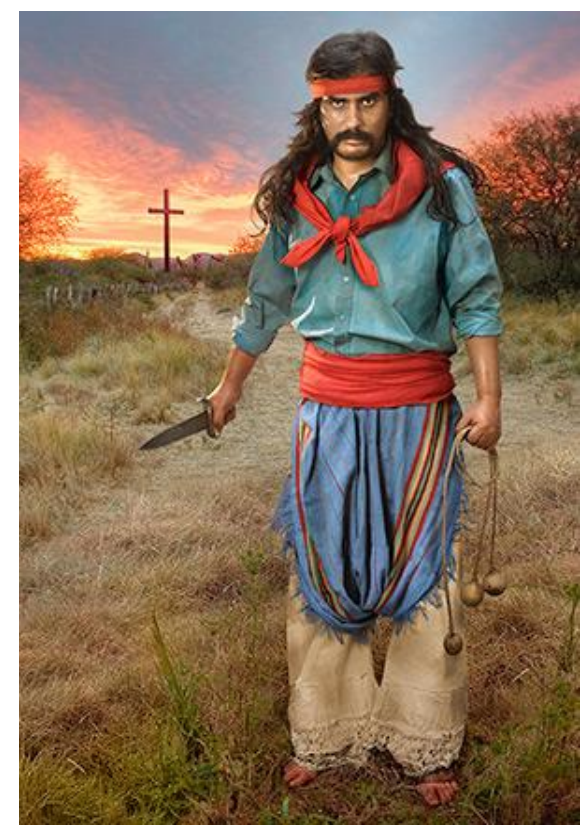

Gaucho Gil. Marcos López. 2008

El fotógrafo argentino, reconocido internacionalmente por su Pop Latino y la serie Sub realismo criollo - a la que pertenece el retrato en cuestión- y que se nutre de la cultura popular-masiva, de la apropiación de juguetes, santos de yeso comprados en santerías para formar instalaciones, también se vio profundamente interpelado por la figura del Gaucho Gil. En ese interés, López llega a ubicar a la figura del "santo" popular en el mundo de su creación junto a la imagen de Evita y Gardel como las más representativas de la argentinidad, así lo señala en diversas entrevistas.

En el retrato de 2008, López realiza una reinvención de la estampita de mayor divulgación del "santo" popular. El fotógrafo recrea al Gauchito en la piel del actor, escritor y editor entrerriano Damián Ríos. Claro, porque esta foto como todas las de Marcos López y aún más en su última etapa de producción, es una gran puesta en escena, teatral, que incluye una posproducción con actitud totalmente pictórica ${ }^{182}$. En esta operación que incluye mecanismos de traducción múltiples, plantea un desplazamiento de la mirada que cuestiona tanto el estatismo de la estampita como la concepción del gaucho apacible y sumiso que ella vehiculiza.

Por un lado, el autor recrimina que la estampa de Gil termine pareciéndose a todas las representaciones de santos del culto oficial. El mismo fotógrafo dice en este sentido:

182 Este aspecto es también desarrollado en el apartado anterior. 


\begin{abstract}
"No me gustaba la pose estática con las boleadoras colgando, y la otra mano caída, sin fuerza. Me daba la impresión de un espíritu de sumisión, o la idea de que todos los santos tienen que asemejarse a la pose de Ceferino. Calma. Como esperando que le pongan las velitas" (López en Saidón, 2011: 38).
\end{abstract}

Por el otro, leído desde las retóricas de la nacionalidad, López cuestiona esa pose estática y más vinculada al gaucho obediente y sometido al patrón de La vuelta del Martín Fierro que doblega a la figura reaccionaria de La ida o la imagen de la resistencia popular de Juan Moreira que según su concepción se vincula más a las historias de los gauchos "alzados" también del Nordeste argentino, como la del propio Gauchito.

En este sentido, López deja de lado la imagen del gaucho que se rinde ante la daga del enemigo sin pelear - como versa parte del final de la leyenda del Gaucho Gil- y rescata el gaucho que prefiere el exilio a ser sometido, que se rebela, como lo habría hecho el propio Gil en momento que huye y empieza a ser perseguido cuando se niega reclutado para los enfrentamientos entre celestes y colorados por rechazo a "derramar sangre de hermanos" como relata también una de las tantas historias que recrean su figura-.

Esta reversión, según las palabras del propio artista, está inspirada más que nada en la figura del gaucho Juan Moreira, que también de cierto modo sigue la línea de la retórica del gaucho Martín Fierro de 1872, pero que a diferencia de éste no representa el gaucho de llanura salvaje y que finalmente regresa sometido al poder, sino más bien de escenario más bien urbano y moderno y que se mantiene rebelado y subversivo hasta que llega su trágico fin.

La novela de Eduardo Gutiérrez reproducida por entregas durante 1879 en $\mathrm{La}$ Prensa Argentina fue llevada tres veces al cine, siendo una de las imágenes más pregnantes, y una de las películas más vistas en la historia del cine argentino, la configurada por Leonardo Favio en el film de 1972 en la piel de Rodolfo Bebán.
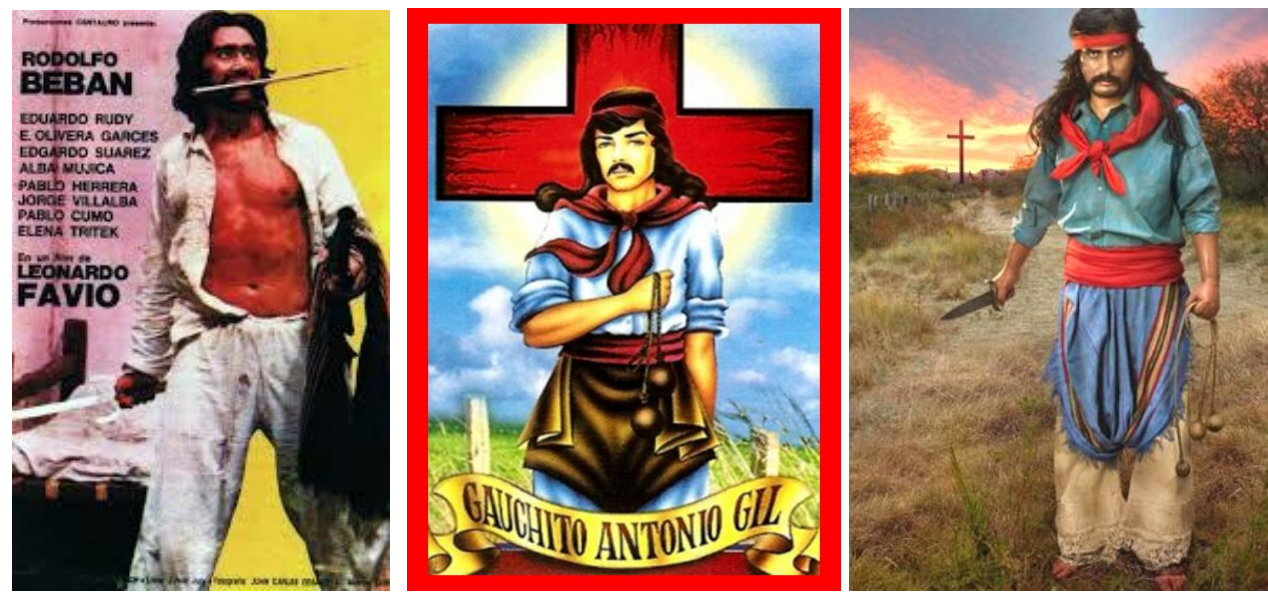
Siguiendo ese planteo del gaucho marginal y perseguido que lucha por sostener a toda costa su dignidad, enfrentando a tiro y cuchillo, el fotógrafo señala "se me ocurrió hacer una mezcla con Juan Moreira como para dar a entender que, cuando venga la policía a detenerlo, él primero matará a cuatro o cinco" (López, en El Cronista, 26/01/2012) ${ }^{183}$.

El antropólogo Alejandro Frigerio en su opinión de este gaucho malevo de Marcos López señala en pocas palabras que esta nueva imagen le devuelve la fuerza a esta figura y reactiva su condición de matrero (Frigerio en Saidón, 2011). Además, se observa que el fotógrafo resitúa al gaucho en el territorio correntino, en la llanura mercedeña: detrás de su imagen se observa el sendero en medio del pastizal que lleva a la cruz rodeada de banderas rojas que señalan el lugar donde fuera degollado. Desde allí, como un momento antes del trágico final, él mira fijo, interpela vigoroso y bravío al espectador, como si enfrentara al enemigo haciendo uso de las boleadoras y también un facón. Es decir, resalta la actitud de estar por entrar en combate antes de entregarse a la muerte.

Llegados a este punto, cabe preguntarse entonces por el gesto político que podría condensar esta rebeldía de López de devolverle visibilidad al gaucho rebelde -valga la redundancia-; de plantear otro modo de mirar al "santo" y "fisurar" con ello la representación "sumisa" más difundida del Gaucho Gil. ¿Acaso López nos advierte de una operación mitológica cristiana católica operando en la configuración de aquella famosa estampita? ¿Acaso su gesto apunta a un intento de desmitificación y de devolverle la historicidad de la rebeldía perdida a aquella imagen?

La forma iconográfica mediante la cual el Gauchito es retratado por López al parecer propone recobrar una parte de la leyenda perdida en el juego de las reproducciones míticas. $\mathrm{Su}$ creación re-conecta al gaucho de los milagros con el gaucho que se rebeló al orden establecido. Se plantea como una forma que decididamente busca apartarse de la iconografía cristiana del sacrificio para plantearse del lado de la rebelión y la liberación.

De este modo, la obra que se plantea irreverente rompiendo los acuerdos sobre los cuales se erigía la imagen más difundida del Gauchito, realiza una apertura al disenso, se propone visibilizar lo no visible y desde esa subjetivación política y estética invita a redefinir lo visible (Rancière, 2010; Reyero, 2014).

\footnotetext{
${ }^{183}$ Referencia disponible en:

http://m.cronista.com/Mobile/nota.html?URI=/contenidos/2012/01/26/noticia_0138.html
} 
Desde allí, la práctica de apropiación fotográfica de López realiza procedimientos de cita, de re-iteración (en el sentido de la repetición pero a su vez de reinvención) del signo original, implicando cambios obvios en el proceso de re-semantización tendientes subvertir los sentidos que se despliegan como dados y naturales, para ponerlos en crisis, encontrar su revés.

Sin embargo, cabe señalar que no deja de ser paradójico y controversial en el caso de López cuando observamos cómo una imagen como ésta, que puede estar cargada de sentido político, leída en los términos aquí realizados, puede volver a reducirse a un estereotipo despolitizado, simpático, fagocitado y banalizado tanto por los medios como por el mercado del arte y otras esferas de consumo cultural. Como advierte el propio López, un poco molesto, "el mercado del arte contemporáneo tiene las mismas reglas que la moda con sus tics, poses y estereotipos" y al formar parte de esa "comparsa que es el mercado", se vive en una "contradicción permanente" y solo queda buscar constantemente nuevas estrategias para escapar del sentido común (López en La Gazeta, 29/11/2013) ${ }^{184}$. En este sentido, el artista reflexiona: "Acepto las influencias, las contradicciones del mercado del arte y trato de reciclarlas desde la periferia" (López, en Esquivada, 2001) ${ }^{185}$.

Desde el riesgo que implica trabajar lo visual, como el mismo fotógrafo señala, “con frases hechas y arriesgar por el camino de la obviedad: primer plano, gran angular, fondo, mensaje social" para más adelante ir camino hacia el núcleo de un problema desde la indagación del "estereotipo del estereotipo", lo que se observa en las instancias de circulación y consumo del retrato de 2008 es que la propuesta de López obliga a ciertos espectadores que se percatan de la irreverencia de López a confrontar los valores naturalizados en torno al "santo", a reafirmarlos, dudar, subvertirlos, a negociar sentidos. Así algunos, en sus estrategias de re-apropiación no se contentan con una imagen tan beligerante y la recortan como en la Fig.2, o borran partes de ella, como sucede con el cuchillo que desaparece en la Fig. $3^{186}$, quitándole así los trazos más desafiantes; o bien frente al reto de López deciden "prenderle velitas" a ese gaucho rebelde sin editarlo tal como lo hacen con el gaucho sometido, como el ejemplo de la Fig.4 donde el post reproduce el retrato completo junto a un agradecimiento $^{187}$, mientras los comentarios rezan "Amén”.

\footnotetext{
${ }^{184}$ Referencia disponible en: http://www.lagaceta.com.ar/nota/570248/espectaculos/marcos-lopez-arte-oficio-hay-sacarle-glamour.html

${ }^{185}$ Referencia disponible: http://www.marcoslopez.com/textos-acerca-batkis.php

${ }^{186}$ Remera comercializada en las ferias de la festividad en Mercedes, Corrientes.

${ }^{187}$ El texto de agradecimiento del perfil de Gauchito Gil Paraná Godoy indica: "No me alcanza las palabras para decir gracias por interceder ante dios por la salud de Mario gracias amen amigo que nunca falta".
} 
Asimismo, en este tránsito de los usos y las apropiaciones múltiples se observa que la fotografía pensada para circular, en primera instancia, en los espacios de arte (Fig.1) es reapropiada por los diversos actores culturales vinculados a prácticas de representación de la figura del Gaucho Gil, como sucede con el grupo La Comedia Municipal de Mercedes que elige un recorte de esa imagen para promocionar su obra (Fig.2), o sectores relacionados a prácticas de comercialización de objetos recordatorios del santo, que imprimen esa fotografía en remeras y accesorios diversos (Fig.3) o la reproducen en espacios virtuales de veneración, como los santuarios virtuales, páginas de facebook dedicada a la figura milagrosa, entre otras donde la operación de de-contextualización y re-contextualización le imprime un nuevo sentido. (Fig. 4).

En esos contextos, se corrobora que el retrato que es investido por un valor estético en un espacio específico y por la relación que establecen ciertos actores del campo del arte con él, en el seno de otros campos, como el de las prácticas rituales es capaz de actuar como fetiche religioso o comercial. La fotografía se re-significa debido a su "propiedad relacional" y los modos en que los sujetos interactúan con ella (Schaeffer, 2012). 


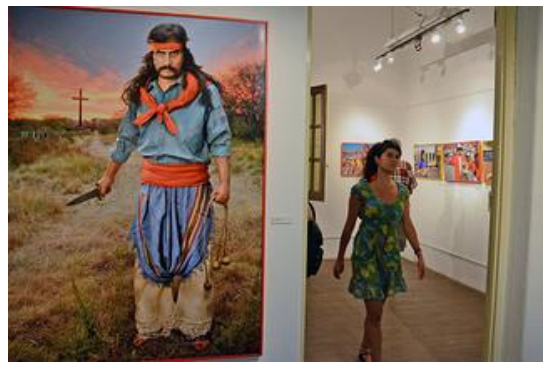

Fig1.

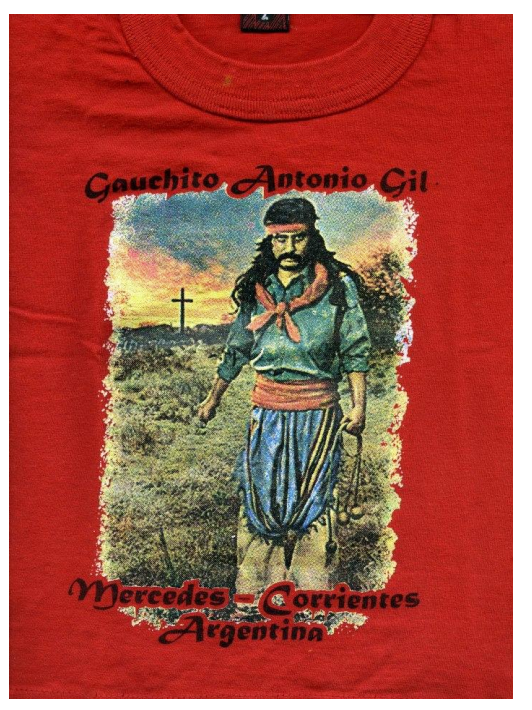

Fig. 3

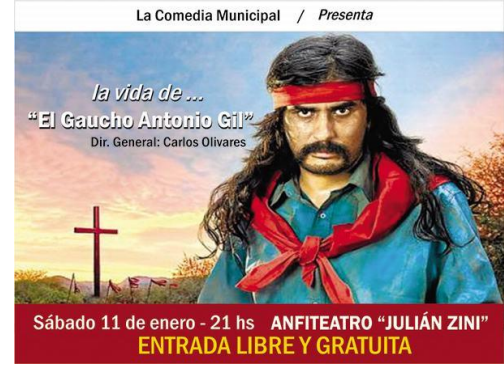

Fig 2.

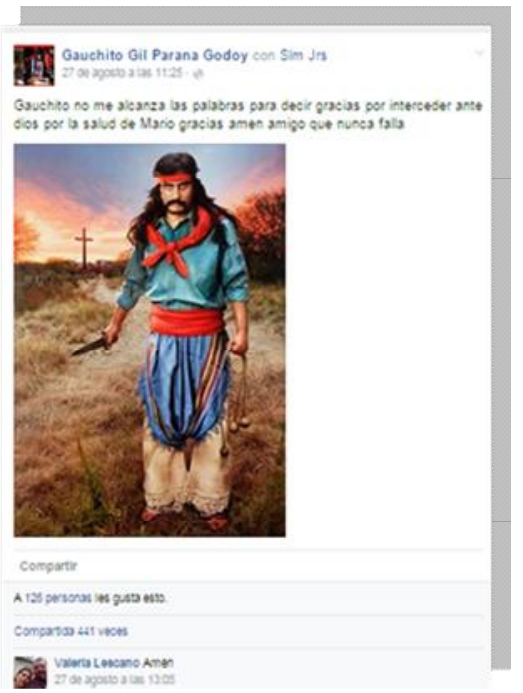

Fig.4.

\section{Notas finales sobre descentramientos de miradas y reconfiguraciones representacionales}

Llegados a este punto, cabe volvernos a preguntar: ¿qué estructuras ordenadoras guían la disposición de los elementos en la captura fotográfica de las prácticas religiosas? ¿Qué elementos/personajes se dan a ver y qué se dejan fuera en esas fotografías?, ¿qué idea de religión y/o de religiosidad popular operan en ellas? ¿de qué modo y en torno a qué premisas las fotos muestran a los sujetos en contextos de los ritos, cómo los vincula con las instituciones y lo sagrado? ¿qué trayectorias atraviesan los fotógrafos y fotografiados, de qué esquemas parten, de cuáles se nutren, cuáles abandonan o subvierten y con qué fines? ¿qué nueva vida cobran las imágenes entre las prácticas y los discursos?

Este capítulo intentó atender a ese grupo de preguntas sin arriesgar respuestas definitivas pero sí abriendo con ellas algunas aproximaciones para pensar los descentramientos de la mirada fotográfica y las reconfiguraciones representacionales que se 
experimentan en el campo de los registros de prácticas religiosas correntinas, en general, y cómo se ubican en ese escenario las imágenes del mundo del Gaucho Gil, en particular.

La indagación de las lógicas e intereses que construyen las maneras de mirar, otorgar visibilidad y ocultar la diversidad de prácticas de la religiosidad correntina, y la focalización como caso ejemplificador en algunas imágenes de la festividad del Gaucho Gil, nos posibilitó observar cómo cada época -definida por la forma de vida y el accionar de diversos sectores sociales- instaura un régimen de visibilidad que modela los esquemas representacionales vigentes.

Del análisis contrastivo realizado y expuesto en estos últimos apartados, incluyendo algunos desarrollos del Capítulo 4, podemos concluir que con las imágenes puestas a circular a principios del siglo XX se construyó una visión disciplinaria, institucional e influenciada por los cánones de la representación eclesiástica de los rituales. Estos esquemas incluso se reproducen en las formas contemporáneas de representar las prácticas religiosas católicas y populares no excluyentemente católicas, sobre todo en lo que respecta a aquellas imágenes difundidas por los medios tradicionales de comunicación masiva. Hablamos de esquemas de representación donde predomina una composición estática y de planos generales que privilegia la visibilización de la multitud de las procesiones y de los rituales más formalizados e institucionales, incluso en los casos que refieren a festividades más informales como la del Gaucho Gil; mientras que en los planos medios y cortos se pone de relieve el posicionamiento de determinados actores que ocupan un rol representativo dentro de los esquemas de poder del orden social legitimado.

Sin embargo, también advertimos que una serie de transformaciones socio-culturales propiciaron hacia los años 1980 y 1990 un cambio de los modos de mirar y valorar las prácticas religiosas correntinas y en ese proceso reconfiguración representacional tuvo mucho que ver la expansión de devociones populares como la del Gaucho Gil. Sin dejar de circular y reproducirse el esquema representacional anterior, se evidencia la sobreimpresión de un segundo régimen de visión predominante que tiene que ver con una estética melodramática y barroca o neo-barroca que impregna las representaciones visuales en el ámbito de las comunicaciones masivas, la documentación y arte.

$\mathrm{Al}$ respecto, cabe señalar que esa forma melodramática-barroca de mostrar los rituales presenta una naturaleza paradojal: por un lado, permite visibilizar la diversidad religiosa, los dramas, las pasiones, lo festivo, los relieves, los espesores, el desborde propio de las manifestaciones de los márgenes del orden racional y disciplinado; exponiendo sujetos, prácticas antes ocultados como así también el carácter diferencial de la religiosidad popular 
contemporánea; mientras, por otro, se observa que algunas imágenes ejecutan operaciones reducción de la densidad de ese "mundo melodramático y barroco" a un recetario de fórmulas visuales de alto impacto y representaciones estereotipadas destinadas al consumo ligero del mercado massmediático.

Pese a que resulte complejo, esa diversidad de miradas no puede ser entendida solamente en términos de oposición sino de entrecruzamientos porque el mismo paisaje cultural popular-masivo que caracteriza a las devociones populares actuales, como la propia festividad del Gaucho Gil, está hecho de esos cruces, intersecciones que impactan y construyen las re-presentaciones fotográficas.

Ahora bien, así como insistimos más arriba que la mirada surge como producto de esos regímenes de visibilidad; los cruces y la diversidad de miradas yuxtapuestas hablan no sólo de la coexistencia -aunque sea desigual- de diferentes regímenes escópicos -en términos de Jay (1988)- funcionando en la producción de sentidos de "lo religioso" desde lo visual, sino también refiere a cómo los regímenes comportan "franjas de indeterminación" - al decir de Reguillo- desde las cuales las miradas logran descentrarse de un esquema para introducir variantes de sentidos.

En la configuración de esa franja de indeterminación transformadora, las fotografías de los cinco fotógrafos aquí indagados muestran diferentes composiciones de encuadre, de estilo, de concepto que se sobreimprimen en el visionado de conjunto, otorgándonos distintos matices del mundo del Gaucho Gil y con él re-matizan también las formas de representar las prácticas religiosas correntinas en general. Y en este escenario como indica Reguillo: “(...) aquello que era in-visible de un modo dado por las lógicas del poder se transforma en virtud de la acción de algunos actores en situaciones históricas particulares (...)”. Desde allí, mirar de otro modo, ser mirado de otro modo, implica movilizar los cimientos mismos en los que reposa un orden asimétrico, excluyente y estigmatizador (Reguillo, 2008: 2).

En esta línea, como alternativa al esquema de impacto massmediático simplificador, desde nuestra perspectiva plantean prácticas descentramiento de la mirada y algunos intentos de re-distribución de lo sensible - en términos de Rancière- las búsquedas personales de los fotógrafos que apuntan a visibilizar los bordes de la festividad, el mestizaje, la densidad de la atmósfera socio-cultural, las condiciones de vida y las prácticas identitarias de los participantes desde las cuáles éstos marcan el territorio de la fiesta y se apropian del mismo.

En este terreno se inscriben algunas producciones de Faccioli y Rusconi analizadas. Así como el trabajo de Eduardo Longoni, uno de los primeros ensayos documentales con una clara línea conceptual de valoración de la festividad desde su potencia visual y la expresión 
e inscripción de la fe en los cuerpos. También la propuesta de Estela Izuel que plantea una de las primeras producciones que centra la mirada en los exvotos, objetos y detalles que configuran la simbología del santuario del Gaucho Gil. Mientras, Marcos López desde su serie Sub-realismo criollo plantea una apropiación de la figura del gaucho Gil para discutir las tramas históricas que lo construyen como símbolo de identidad/alteridad nacional en la configuración de simbologías latinoamericanas.

Por otra parte, en el análisis focalizado en las fotografías "Devoto" de Juan Pablo Faccioli y "Gaucho Gil" de Marcos López y la sucesión de reproducciones, de citas y reapropiaciones, es posible advertir como determinadas imágenes - muy vinculadas a los mitos del origen (la dialéctica del gaucho rebelde y desplazado/obediente e integrado , la nación católica, la iconografía cristiana modelizadora de las representaciones de la cultura argentina, etc)- persisten en la memoria y son reactivados, como señala Malosetti Costa, después de largos periodos para continuar disputando sentidos en los procesos de producción/circulación y consumo de re-presentaciones actuales.

De este modo, como cierre preliminar observamos que en tanto lugar de confrontación de formas que interpelan antiguos y nuevos saberes (Williams, 1980) y como artefacto que produce desde la práctica fotográfica des-centramientos constantes de la mirada -entendida como aquella que desestabiliza representaciones cristalizadas pero también las vuelve a convocar, a reactivar en sus creaciones-, atendiendo a las condiciones que regulan lo fotografiable y lo memorable, la fotografía así como posee la capacidad de ocluir también posee la aptitud para develar y dar visibilidad a la heterogeneidad de prácticas, sujetos, discursos, memorias e imaginarios. 


\section{CAPÍTULO 6:}

\section{Imágenes melodramáticas y proyecciones identitarias en el acto}

fotográfico

En el melodrama está todo revuelto, las estructuras sociales con las del sentimiento, mucho de lo que somos -machistas, fatalistas, supersticiosos- y de lo que soñamos ser, el robo de la identidad, la nostalgia, la rabia. En forma de tango o de telenovela, de cine mexicano o de crónica roja el melodrama trabaja en estas tierras una veta profunda de nuestro imaginario colectivo, y no hay acceso a la memoria histórica ni proyección posible del futuro que no pase por ese imaginario.

Jesús Martin-Barbero, De los medios a las mediaciones

Situados en el campo de estudios de la cultura popular-masiva y las indagaciones sobre el melodrama en las formas de imaginación de la cultura latinoamericana, este capítulo aborda la configuración melodramática y emotiva de estas producciones fotográficas sobre la festividad del Gaucho Gil. Las imágenes son puestas en relación con sus matrices culturaleshistóricas vinculadas a las formas de sentimiento y a las experiencias de encuentro entre los fotógrafos y los grupos populares fotografiados.

Uno de los objetivos apunta entender la re-creación del melodrama que se procesa en las producciones sobre la festividad en el marco de concepciones estéticas emotivas del fotoperiodismo nacional e internacional, así como del arte visual universal; y reflexionar en qué medida esta modalidad enunciativa se plantea, al decir de Martin-Barbero (1998) y Herlinghaus (2002) como una concepción clave para comprender el imaginario moderno latinoamericano; así como los modos en que esa configuración echa raíz en una matriz cultural de larga data que, incluso, nos remite incluso a los elementos retóricos de las formas europeas de los siglos XV, XVI y XVII (como las imágenes sagradas cristianas, la ópera popular, entre otras).

En este sentido, buscamos comprender cómo esa exacerbación de los sentimientos presente en las fotografías se construye, en el marco de la articulación de complejos procesos de objetivación y subjetivación, adscribiéndose tanto a las demandas de mercado y preferencias del público, como a la generación de una entonación expresiva/ tonalidad emotiva (Bajtín, 1982; Papalini, 2011) que tiñe la mayoría de los discursos de la cultura contemporánea. Hablamos de textos que en su mayoría son vehiculizados a través de los 
diferentes dispositivos/formatos/géneros de la comunicación masiva (que van del folletín a la prensa sensacionalista actual, las telenovelas, el thriller hollywoodense y la neotelevisión) en los que también se inscriben los diversos modos de dar a ver que adopta el fotoperiodismo.

Por otra parte, también se indaga en los modos de proyección identitaria que configuran los grupos populares fotografiaos desde los actos fotográficos entendidos como lugar de articulaciones dialógicas e invita a pensar a los retratados como "practicantes, consumidores y co-productores" de estas representaciones.

Las inquietudes surgen del abordaje de una serie fotos sobre la festividad del Gauchito Gil tomadas por los fotoreporteros Juan Pablo Faccioli y Guillermo Rusconi entre 2008 y 2011 para su publicación en la prensa y la observación de algunas trayectorias de fotografiar de estos dos fotógrafos en el marco de dicha festividad entre 2010 y 2011.

\section{El melodrama fotográfico de la cultura popular-masiva}

Los interrogantes y reflexiones volcados en este texto siguen la trayectoria de los estudios latinoamericanos de la Comunicación/ Cultura que buscan entender las vinculaciones entre cultura popular y cultura masiva (Martin-Barbero, 1984, 1998); Herlinghaus, 2002; Terrero; 1983, Rivera, 1980; Ford, 1985; Romano, 1973).

Desde esta perspectiva se entienden a las narrativas melodramáticas difundidas a través de los medios masivos no como meros productos de consumo y/o como modalidades enunciativas que por su operatividad y efectividad ideológica son puestas a circular desde los sectores dominantes para atender a sus intereses de control y manipulación de las masas, sino que se observa la constitución de lo melodramático en lo masivo desde una visión más compleja: como una trama que logra tejerse desde la permanente negociación con las experiencias, las demandas y la asimilación de los códigos de los sectores populares (MartinBarbero 1998, Rodríguez, 2010).

En esta línea, el melodrama se comprende no sólo como un tipo de estética que se vale de la exaltación de lo sentimental y lo patético en sus formas con el fin de conmover al espectador, sino como un modo de narrar y de sentir, de dar sentido al mundo más abarcativo. Una modalidad que echa raíz en una matriz cultural de larga data de fuerte ligazón con la tradición popular que atraviesa el imaginario moderno tiñendo con una predominancia de lo subjetivo a la mayoría de los discursos de la cultura contemporánea (Martin-Barbero, 1998; Herlinghaus, 2002). 
Desde esta visión esta reflexión se encamina a comprender al melodrama fotográfico de prensa, desde su condición de discurso afectado (Deleuze, 1993) pero también como una configuración que tiene la capacidad de mediar entre los imaginarios, las manifestaciones y demandas de los sectores populares como de los sectores dominantes, articulada a los formatos y lógicas industriales de producción y consumo de la cultura de masas.

De este modo, esta indagación participa de las preocupaciones que siguen la requisitoria de Jesús Martin-Barbero (1984) de pasar de estudiar los medios a las mediaciones, entendidas como esas instancias socio-culturales que atraviesan y llenan de sentido a los actos de comunicación, es decir de pensar la comunicación desde los procesos de socialización y reproducción de la cultura.

Un requerimiento de consideración no menor a la hora de hablar de la definición identitaria de los estudios comunicacionales de la región, ya que no solo hizo explícito en los años ochenta en América Latina un viraje del paradigma mediocéntrico hacia la reflexión de la comunicación desde la cultura; sino que propició el reemplazo de la $y$ de "comunicación $y$ cultura" por la barra "comunicación/cultura" restringiendo desde entonces la posibilidad de pensar estas dimensiones por separado (Schmucler, 1984; Saintout, 2003 y 2008).

Asimismo, en este contexto Martin-Barbero, entre otros, desarrolló su trabajo sobre la cultura popular y la imposibilidad de pensarla ya separada de las retóricas massmediáticas, dando lugar a los planteos sobre "cultura popular- de masas" (Martin-Barbero, 1998, Rodríguez, 2010). Dicho sintagma nos permite pensar el corrimiento de la $y$ de "cultura popular $y$ masiva" para discutir la cultura popular-masiva como la lectura de dos ámbitos diferentes pero a la vez profundamente articulados por el guión.

Esta reflexión sigue los escritos de la línea barberiana pero también busca reconocer las preocupaciones ya instaladas en el ámbito nacional por Ford, Terrero y Romano, desde trabajos de crítica literaria y de medios masivos, actualmente retomados en el campo de la Comunicación/Cultura.

A la luz de estos debates se propone la indagación del fotoperiodismo por un lado atendiendo a las matrices culturales históricas entendidas éstas como fuentes de significados desde donde los productores y co-productores comprenden y otorgan sentido al mundo en la configuración del reportaje visual. Referimos a las tramas situacionales, de temporalidades y materialidades socio-históricas, culturales y políticas diversas que atraviesan y configuran las 
formas heterogéneas de la imagen ${ }^{188}$. Y por el otro reflexionando sobre la experiencia de los fotógrafos y los sectores populares retratados, desde el acto fotográfico.

Ello sin desatender que la fotografía como uno de los dispositivos privilegiados de la cultura de masas, si bien aparentemente niega desde esa matriz a lo popular, a su vez se define por el cruce de experiencias concretas de los fotógrafos y los sectores populares fotografiados, constituyéndose como espacio posible de existencia y visibilización de lo popular. Es decir, como terreno apto a ser interrogado desde las ideas de intersección, diálogo y articulación entre la cultura popular y la cultura masiva (Martin-Barbero, 1998).

\section{Las matrices históricas-culturales de las formas de sentimiento}

Desde la consideración de la historia y la densa memoria que las imágenes condensan $^{189}$, las formas melodramáticas en el fotoperiodismo actual no pueden leerse ni comprenderse como el resultado de la simple creatividad de los hombres de detrás de cámara o de una evolución autónoma, independiente, sino como el "eslabón de una cadena, muy complejamente organizada, de otros enunciados" (Bajtín, 1982: 252), en constante diálogo con discursos precedentes.

En ese sentido, se observa que estas formas tienen sus antecedentes en la ópera, la tragedia griega, las representaciones de la plástica del cristianismo católico, caracterizadas por el martirio y el sufrimiento (Burke, 2005), entre otros. Sólo un repaso por los modos de narrar de esas producciones evidencian que pensando en su función persuasiva, desde el drama y lo teatral ya en las iconografías sagradas y puestas artísticas más antiguas se trabajó la asimilación de códigos populares de percepción y reconocimiento con el fin de impactar en el espectador.

\section{2.a)- La configuración emotiva de las representaciones artístico-comunicativas}

Si bien como sostienen varios autores el estudio de los actores sociales desde el punto de vista de las emociones que ellos experimentan ante determinados fenómenos socioculturales, ha cobrado nuevo vigor en las últimas décadas en el campo de los estudios de las ciencias sociales en general y de la comunicación y la cultura masiva en particular (Elías,

\footnotetext{
${ }^{188}$ Dice Martín Barbero: "Matriz no es evocar lo arcaico sino hacer explícito lo que carga el hoy (...) Indagar no lo que sobrevive del tiempo (...) sino lo que hace que ciertas matrices (...) sigan secretamente conectando con la vida de la gente" (Martín Barbero, 1988: 137).

${ }^{189}$ Al respecto Didi Huberman dirá: "La imagen a menudo tiene más memoria y más porvenir que el ser que la mira" (Huberman, 2009: 32).
} 
1987; Hansberg, 1996; Le Breton, 1999; Papalini, 2011), Aumont (1992:129) advierte sobre la escasez de estudios relacionados al tratamiento del valor emocional de la imagen en ámbitos de recepción.

Entendemos que sin entrar a discurrir en los prolíficos ensayos sobre esta problemática en el área del marketing y la publicidad que han tenido mayor trascendencia a partir de los años noventa, el autor encuentra en Francis Vanoye (1989) casi el único trabajo de referencia para hablar de las tipologías de emociones generadas en el espectador en ese caso inmerso en la experiencia cinematográfica ${ }^{190}$.

No obstante Aumont destaca la fructífera problematización de la cuestión ligada a la producción de obras de arte en el seno de la estética, donde la emoción ${ }^{191}$ se relaciona al componente expresivo de las imágenes. Sin proponer un concepto acabado, atendiendo a la contraposición de perspectivas vigente, el investigador rescata que "la idea de expresión apunta al espectador (individual o más anónimo), y que transmite significados exteriores a la obra, pero movilizando técnicas particulares, medios que afectan la apariencia de la obra" (Aumont, 1992: 299).

En otras palabras, la construcción de un discurso expresivo, un discurso afectado "que trata de salirse del canon de la no manifestación y la contención para desbordar" en la obra (Delgado, 2007: 229) implica un procedimiento. Un tratamiento particular de la composición visual (forma, color, movimiento) que tiende a exaltación de determinados valores plásticos en detrimento de otros (regulación de intensidad de los afectos ${ }^{192}$ ) sujeto a fines y condiciones de producción y recepción específicas.

En esa línea y en nuestro intento de historizar las configuraciones emotivas de las representaciones artísticas comunicativas, encontramos que ya hacia fines de la Edad Media se procuraron construcciones culturales con el fin de suscitar emociones e impactar en el espectador. En este sentido, Peter Burke (2005) al explorar a nivel iconológico las imágenes

\footnotetext{
190 A partir de Vanoye y su trabajo sobre cine y los efectos en los espectadores, Aumont da cuenta de la existencia de una división entre tipos de emociones neutras y negativas y señala pocas positivas. Vanoye hablará de las emociones "fuertes" ligadas a la supervivencia y el estrés despertadas por el film (el miedo, sorpresa o la novedad) y las relacionadas a la reproducción y a la vida social (la tristeza, la afección, el deseo, el rechazo).

191 Tanto desde el aspecto terminológico como desde la consideración de su naturaleza, la emoción es objeto de controversia. Diversas perspectivas han tratado su causalidad y al construirse como punto de convergencia de elementos cognitivos y no cognitivos, se ha convertido en un cuerpo polisémico que no admite una conceptualización unitaria.

192 Para Deleuze la afección es entendida como el "efecto" de una imagen sobre quien la mira, "que envuelve e implica un afecto" (Deleuze, 1981 en Delgado 2007:229). Mientras entiende a la obra de arte como "un ser de sensación". Se construye por "acordes de tonos o de colores que son los afectos de la música y o de la pintura (...) El artista crea bloques de preceptos y de afectos (...) El artista es presentador de afectos, inventor de afectos, creador de afectos, en relación con los preceptos o las visiones que nos da. No sólo crea su obra, no las da y nos hace devenir con ellos, nos toma como compuesto" (Deleuze, 1993:165-177).
} 
sagradas de ese tiempo explica cómo se produjo un profundo cambio estilístico que pasó de concebir formas poco expresivas y más bien estáticas a formas cada vez más dramáticas y teatrales.

El autor señala que entre los siglos XV y XVI se dio "una preocupación especial por el dolor" que llegó a su punto culmine con "el culto de los instrumentos de la Pasión, los clavos, la lanza, etc. (...) y fue también la época en la que "el Cristo sufriente, retorcido y patético, sustituyó la imagen serena y dignificada de los crucifijos". Mientras que adentrado el siglo XVII el interés se posó en las representaciones del éxtasis" (Burke, 2005: 63).

Para Burke esas formas se consolidan cuando la Iglesia a través del Concilio de Trento (1545-1563) ratifica la importancia de las imágenes sagradas así como la de las peregrinaciones y reliquias para la difusión y reafirmación de la doctrina ${ }^{193}$.

En ese marco, más precisamente en el siglo XVII, también con una estética con predominio de lo sentimental surge el melodrama, término (que viene del griego canción y del francés drama) acuñado por el filósofo Jean Jacques Rousseau para referirse al género de la ópera popular que combina despliegue teatral, canto y música instrumental con la caracterización de personajes estereotipados con actitudes grandilocuentes tendientes a suscitar procesos de identificación inmediata en el público y un efectismo que de cierta manera los llevaba a "vivir", o más bien "sentir" las representaciones.

Así como algunos autores encontraron la raíz de los componentes de esta ópera en la tragedia griega, también otros relacionaron las representaciones de la plástica del cristianismo católico, caracterizadas por el martirio y el sufrimiento, con el modo dionisíaco pero con significaciones opuestas ${ }^{194}$, entendiendo además que estas formas son la fuente del imaginario melodramático que dominará la época moderna expandiéndose a través de la ópera popular hasta impregnar los formatos más actuales.

Esa reproducción anacrónica de la imaginación melodramática (Brooks, 1976; Herlinghaus, 2002), con un desarrollo paradigmático a partir del siglo XIX, será leída como un hecho clave en la configuración de la imaginación moderna en general y latinoamericana en particular.

193 Cabe aclarar que el Séptimo Concilio Ecuménico de Nicea (año 787) es el que justificó el culto de las imágenes como medio proselitista de amplio alcance. De allí se dio la propagación de imágenes destinadas a los laicos analfabetos como a los clérigos para su la lectura (Gombrich, 199: 51). No obstante esas primeras figuras fueron criticadas o por su alta complejidad o falta de eficacia para el "adoctrinamiento", hasta que las formas más teatrales y a su vez focalizadas en la comunicación gestual apuntaron a la persuasión logrando servir como propaganda a favor de la Iglesia (Burke, 2005: 59-74)

${ }^{194}$ Consultar Ott, Michaela. "El discurso de lo melodramático. Entre el cristianismo, psicoanálisis y cine", en Herlinghaus, Hermann -editor- Narraciones anacrónicas de la modernidad. Santiago de Chile. Cuarto Propio, pp254-260. 


\section{2.b)- Capturas de sentimiento, fotoperiodismo y religiosidad popular}

Las formas melodramáticas en el fotoperiodismo actual no pueden abordarse sin tener en cuenta los antecedentes en aquel melodrama iconográfico y musical espectacular y popular referenciado, y otras representaciones del "realismo grotesco de la cultura medieval" (Bajtín, 1990) no mencionados.

Si bien, buena parte de las imágenes sagradas de la Edad Media fueron absorbidas luego por el estudio de la Historia del Arte, disciplina que le otorgó el status de "arte" digno de ser contemplada por la cultura "culta", es evidente que pensando en su función persuasiva, desde el drama y lo teatral en ellas se trabajó la asimilación de códigos populares de percepción y reconocimiento. Una tarea y una estética que se acentuaría primero en su camino de travesía por los géneros concebidos propiamente como "populares", como el teatro circense, el melodrama (ópera popular) entre otros; y después por los géneros masivos ${ }^{195}$, como las novelas de folletín, la radio novela, la telenovela, la música folklórica, la crónica sensacionalista, el cine (desde las producciones de posguerra al thriller hollywoodense), así como los formatos del nuevo periodismo y la neotelevisión.

En la fotografía de prensa la exacerbación de los sentimientos aparece con fuerza en el siglo XX. Por sólo citar algunos antecedentes de las imágenes actuales podemos recordar: "Niños negros con muñeca blanca" de Gordon Parks en 1912 o "Madre Inmigrante" de Dorothea Lange en 1936, que sobresalen entre las imágenes centradas en la temática de raza, clase y discriminación. "Miliciano herido" de Robert Capa tomada en 1936, que devino en símbolo de la guerra civil española; o las imágenes de los campos liberados que reflejaron las atrocidades del Holocausto como "Buchenwald" de Lee Miller en 1945; "El beso" entre un marino y una enfermera que se convirtió en emblema del fin de la Segunda Guerra en 1945 tomada por Alfred Eisenstaedt; la famosa foto de niña que huía desnuda de los bombardeos durante la guerra de Vietnman en 1972 de Nick Ut; el retrato del rostro de la niña de ojos verdes en el campamento de refugiados de Pakistán en 1984 del fotógrafo Steve McCurry; entre otras tantas relacionadas a la hambruna en Asia y África o los desastres naturales, etc.

\footnotetext{
${ }^{195}$ De hecho, la cultura de masas encuentra su origen junto a la literatura de cordel y el melodrama de los siglos XVI y XVII y se expande hacia el siglo XIX con sus "productos destinados al consumo de las masas" (Adorno y Horkheimer, 1969), que si bien responden a los intereses de homogeneización religiosa y centralización política, desde la posición de Barbero no constituían "pura ideología, ya que no solo abren a las clases populares el acceso a la cultura hegemónica, si no que les da a esas clases la posibilidad de hacer comunicable su memoria y su experiencia” (Barbero, 1998: 133).
} 
Este tipo imágenes abonaron la configuración de una “era de la conmoción”, que para Sontag inicia con las fotos de la Primera Guerra Mundial (Sontag, 2003) y se caracteriza por la creciente recurrencia de temas vinculados al horror, el terror, la violencia, la tragedia, la pasión, el dolor, que tienen de cierto modo su plataforma en la agenda que han construido e instalado las publicaciones ilustradas (ya dominadas por la fotografía a partir de los años 20 y 30) y el desarrollo de la prensa sensacionalista, a su vez luego influenciada por el fuerte contenido iconográfico emotivo de la TV . Estas prácticas periodísticas tuvieron un rol determinante en la actual organización simbólica de la percepción y la representación del mundo.

$\mathrm{Al}$ respecto y a partir de su estudio centrado en fotos de guerra Sontag dirá:

Ser espectador de calamidades que tienen lugar en otro país es una experiencia intrínseca de la modernidad, la ofrenda acumulativa de más de siglo $y$ medio de actividad de esos turistas especializados y profesionales llamados periodistas. Las guerras son ahora también las vistas y sonidos de las salas de estar. La información de lo que está sucediendo en otra parte, llamada "noticias", destaca los conflictos y la violencia - "si hay sangre, va en cabeza", reza la vetusta directriz de la prensa sensacionalista y de los programas de noticias que emiten titulares las veinticuatro horas - a los que se responde con indignación, compasión, excitación o aprobación, mientras cada miseria se exhibe ante la vista (Sontag 2003: 27).

Pese a las abundantes críticas a la certeza de veracidad con la que se vincula a la fotografía de prensa, que insisten en develar su carácter de invención no inocente ${ }^{196}$, para Sontag (2003), más allá de que las producciones hayan sido construidas, el fotoperiodismo contiene un valor ético que reside en su capacidad de colocarnos "ante el dolor de los demás" y al mismo tiempo generar "indignación moral” o compasión, entendiéndolas como un "primer movimiento emocional" que puede llevarnos a la toma de conciencia, a la reflexión y a desencadenar acciones sólo posibles, según Papalini (2011), gracias a la mediación racional de la acción solidaria.

Es decir, más allá de que las fotografías constituyan un cofre que resguarda una intención de persuasión concebida en el acto de creación, como parte del régimen indicial prevalece en ellas su condición de ser registro/huella de una fracción de lo acontecido ${ }^{197}$, lo

\footnotetext{
196 Véase Pérez, David (ed) La certeza vulnerable. Cuerpo y fotografía en el siglo XXI. Gustavo Gili, Barcelona, 2004.

${ }^{197}$ Sontag relata cómo a pesar de lo inventivo con las fotos de guerra se realza el carácter testimonial de las fotos de prensa. "Las fotografías tenían la virtud de unir dos atributos contradictorios. Su crédito de objetividad era inherente. Y sin embargo tenían siempre, necesariamente, un punto de vista. Eran el registro de lo real incontrovertibles, como no podía llegar a serlo relato verbal alguno pese a su imparcialidad - puesto que una máquina estaba registrándola. Y ofrecían testimonio de lo real, puesto que una persona había estado allí para hacerlas" (Sontag, 2003: 35).
} 
que genera efectos de verdad y que expuesta ante la mirada del espectador lo puede "mover a la compasión" y por consiguiente "a la intervención en la esfera pública" (Papalini, 2011).

En este sentido pueden leerse las protestas en contra de la guerra, particularmente contra la presencia de Estados Unidos en Vietnam, tras las impactantes fotos de vietnamitas y estadounidenses heridos que circularon en los medios y que derivó en la censura y autocensura a la publicación fotos de las guerras siguientes (Malvinas, Afganistán, etc) al tomarse conciencia desde distintos estamentos del poder y de la empresa mediática sobre el efecto movilizador de las imágenes en el espectador devenido en actor de protesta ${ }^{198}$.

En esa línea podrían también interpretarse las manifestaciones de adhesión colectiva con el advenimiento de la democracia al "Nunca Más" tras la difusión de las fotos de episodios ligados a la dictadura argentina o la visibilidad del reclamo por los desaparecidos a través de las imágenes en la prensa de las Madres de Plaza de Mayo; las marchas al pedido de justicia y esclarecimiento del atentado a la AMIA tras la revelación pública las imágenes de la tragedia y el dolor de familiares de las víctimas; o la decisión de sumarse a la protesta y al "Que se vayan todos" tras las primeras imágenes del "cacerolazo" y la represión que se vio en la TV y en la portada de los diarios en plena crisis económica argentina en 2001 (tal vez uno de los mejores ejemplos del efecto de indignación moral), entre otros.

Lo repasado nos lleva pensar la (re)creación del melodrama en la fotografía de prensa ligada a búsquedas estéticas que reproducen con mayor o menor fuerza dependiendo de los objetivos de impacto, ciertas recetas heredadas del pasado dominadas por el exceso del gesto, entendido como figura de la acción, y de los movimientos del rostro y del cuerpo, como testimonios de la afectividad (Le Breton, 1999:38-39). Como así también se ve relacionada a valores éticos que en el mejor de los casos se vale de elementos persuasivos para dar a ver y llamar la atención del espectador sobre ciertas problemáticas sociales.

Asimismo, este proceso recreativo también se liga y se adscribe a las demandas de mercado donde el componente ético se ve muchas veces desplazado o cobra menos relevancia ante la necesidad de la empresa periodística de publicar imágenes cada vez más dramáticas, sea o no oportuno o controversial desde lo moral, para alimentar la cultura de la conmoción "que se ha convertido en la principal fuente de valor y estímulo del consumo" (Sontag; 2003: 32). Ese estímulo consumista se incrementó a través de los años con la circulación, réplica y/o adaptación de las imágenes melodramáticas a los de distintos géneros discursivos promovidos por la industria cultural (de las portadas de la prensa gráfica a la TV o al cine y viceversa).

${ }^{198}$ Véase Sontag, Susan. Ante el dolor de los demás. Santillana, Barcelona, 2003, pág. 20. 
Esa especie de retroalimentación, que ya se daba con la reproducción de las historias melodramáticas del folletín pasadas a los escenarios teatrales entre el siglo XIX y siglo XX ${ }^{199}$ , no solamente fortificó el negocio sino también la configuración del imaginario melodramático que hoy no sólo administra las predilecciones de consumo sino que a su vez se constituye en una constante negociación con esos gustos del público ${ }^{200}$. Preferencias que reafirman su inclinación por esta modalidad narrativa emotiva en la que la gente común ha encontrado un espacio para contar su experiencia de vida, para luchar contra el anonimato, en definitiva acceder al protagónico que en tiempo de los metarelatos estaba reservado a las pocas historias heroicas y ejemplares.

Vanina Papalini sostiene que la tendencia actual al tratamiento de temas vinculados a la subjetividad se da en el marco de un movimiento que va del ethos al pathos. (Papalini, 2011). Lo que en términos de la estructura del sentimiento/sentir (Williams en Papalini, 2011), puede leerse como el traspasamiento que se ejerce desde la exacerbación de los sentimientos (impulso) por sobre los límites que impone la norma hasta el momento preestablecida, la restricción (que regula el movimiento afectivo/controla las emociones).

Este corrimiento propicia la configuración de una tonalidad emotiva ${ }^{201}$ particular que signa la época contemporánea con lo subjetivo puesto en primer plano, al punto de aparecer plasmado en "buena parte de los discursos sociales circulantes" y anidar "en innumerables producciones culturales", en cuyo seno las formas y narrativas emotivas prevalecen centradas en el "sujeto", comprendido a su vez como la "figura emergente" de este tiempo.

Entre esas representaciones cobrarán relevancia, especialmente a fines de la década del 80 y principios del 90 y en el marco del descrédito de los llamados metarelatos (Lyotard, 1987; Angenot, 2005), microrelatos como el testimonio, la autobiografía y la historia de vida, que se configuran como un espacio clave de identificación y de comunicación de la experiencia vivencial del sujeto. Todos estos modos de narrar entrelazados, es decir con fronteras inestables o más bien borroneadas, propician la consolidación del "Yo sensible y sentimental” (Colón, 2000: 144) que empezó a construirse a fines del siglo XIX.

199 Sobre esa reproducción Sarlo sostiene que "hubo un círculo vicioso: constituyó un imaginario colectivo y una estética, pero también se retroalimentó de éstos para perfeccionar el negocio; un negocio que ha continuado y que está de mostrado por el éxito de la te le no ve la con temporánea que mantiene casi invariablemente, con algunas excepciones, la estructura y las operaciones simbólicas me lo dramáticas del folletín" (Sarlo, 2000: 39). 200 La noción de negociación se opone a la concepción del rol pasivo del público en el consumo de productos de la cultura masiva.

201 "La tonalidad emotiva establece las condiciones y los límites de la expresión; permite ciertas demostraciones subjetivas y acalla otras: el "tono" no supone el silenciamiento de los sentimientos sino la atenuación de algunos y el énfasis de otros" (Papalini, 2011). 
En medio del desarrollo de estas "narrativas del yo" la fotografía en general y la de prensa en particular goza de una vida prolífica, pues en diálogo con otros textos (intertextualidad) se ocupará de dar visibilidad a las distintas formas de vivencias desde la cotidianeidad, las realidades de una diversidad de sujetos/actores cuya imagen e historia hasta el momento fue menospreciada y relegada de las primeras planas y pantallas: mujeres, ancianos y niños marginados, desocupados, mendigos, delincuentes, prostitutas, gays, lesbianas, transexuales, etc. Pero asimismo por su condición de ser huella de lo fotografiado, de actuar como espacio que "pone de manifiesto, con mayor nitidez, la búsqueda de la presencia como resguardo inequívoco de la existencia, de la mítica singularidad del yo" articulará la preeminencia de lo vivencial con la “obsesión de certificación, el testimonio (...) el efecto vida real (de) lo verdaderamente ocurrido" (Arfuch, 2002:61) como criterio que domina la construcción del discurso que irrumpe en la escena mediática actual.

En este marco, la búsqueda de la captura de sujetos populares inmersos en espacios y situaciones años atrás excluidos del campo de la representación (cotidianidad, sexualidad, prácticas culturales diversas, prácticas laborales inmersas en su vasta dimensión cultural) también ayudará a visibilizar la diversidad de prácticas religiosas, donde el dominio de las religiones históricamente instituidas se diluyen para dar cabida a nuevas variantes que apuntan a satisfacer las necesidades de los sectores sociales cada vez más variados.

Los elementos particulares de las prácticas de religiosidad popular como "la ubicuidad de la intervención de lo sobrenatural en la vida cotidiana de las personas; la comunicación directa con la Divinidad durante y fuera de los rituales, la relación estrecha y personal con ella (...) la importancia de lo emotivo y lo afectivo en esta relación y el rol activo del fiel en la propiciación de sus favores” (Frigerio 1995: 46) llamarán particularmente la atención de la empresa periodística que verá en esas manifestaciones una fuente inagotable de testimonios e historias de vida melodramáticas e impactantes - también abonados por otros factores como la masividad, la espectacularidad, rareza, entre otros antes señalados- que alimentarán sus páginas, sus ventas y se ubicarán primeras en las preferencias de consumo.

En este marco proliferan las fotos de prensa que dan a ver la cosmovisión de la religiosidad popular. De hecho en las últimas muestras de la World Press Photo, la Asociación de Reporteros Gráficos de la República Argentina pudieron verse varias selecciones de imágenes que exploran diversas miradas en torno al tópico. Incluso en el ámbito de la fotografía documental y artística, desde la temprana indagación hacia la década del setenta y ochenta de María Cristina Rodero - la reconocida fotógrafa española de la agencia Magnum- en el mundo de los rituales y fiestas de la religiosidad popular, se cuentan 
hasta la actualidad cientos de producciones referentes al tópico, siendo el caso del Gaucho Gil uno de los más abordados en el país.

\section{El Gauchito melodramático en la práctica de fotografiar de Faccioli y Rusconi}

En el marco del auge de la difusión del culto al Gaucho Gil, Juan Pablo Faccioli y Guillermo Rusconi iniciaron en 2004 y sostuvieron hasta 2014 una serie de producciones fotográficas sobre la festividad central en el santuario de Mercedes, Corrientes. Por su búsqueda continua y compartida en los últimos años, seleccionamos algunas tomas de 2008 a 2012 de estos autores para reflexionar en este apartado sobre las rupturas, continuidades, viejas y nuevas demandas que condicionan los modos de dar el mundo del Gaucho Gil. El análisis se realiza en relación a datos que surgieron de las conversaciones mantenidas con los autores $^{202}$ y la observación de algunas trayectorias de fotografiar de estos dos fotógrafos realizada en el marco de dicha festividad entre 2010 y 2011.

Lo indagado da cuenta que en principio el objetivo de estos trabajos fue responder al aumento de demanda de imágenes que la multitudinaria manifestación religiosa popular generó desde distintos medios de comunicación masiva. Cabe recordar que los fotógrafos realizaron coberturas para diarios provinciales y nacionales y agencias de noticias nacionales. Sin embargo, la experiencia del acto de fotografiar provocó en ellos la necesidad de pasar de alguna manera a ser parte de esa fiesta con el fin de dar a ver desde adentro o por lo menos desde una mirada más cercana los fragmentos de ese complejo universo, por lo que los viajes al epicentro del festejo se hicieron más frecuentes y con estadías menos acotadas.

Frente a un cúmulo importante de las imágenes resultantes guardadas en el ordenador $^{203}$ se puede observar cómo ambos reporteros retratan en primer lugar la multitud, el amontonamiento de gente en las inmediaciones del santuario, el caos que caracteriza a la festividad vista desde una primera aproximación al tramo de la Ruta Nacional 123 donde se ubica la Cruz Gil.

Una imagen de Rusconi que imita una perspectiva aérea es quizá uno de los mejores ejemplos de las horas cumbres del día central de la fiesta del 8 de enero. Ésta es ante todo gente que viene y que va, gente que se choca, gente que se confunde con una marea; una

\footnotetext{
202 Ver Anexo.

203 El visionado de las imágenes se realizó junto a los fotógrafos en sus notebooks durante las entrevistas realizadas entre 2012 y 2013. También la hipótesis de la búsqueda más implicada para una captura más reflexiva que desarrollamos en este apartado desde el análisis de las imágenes es corroborada por los propios fotógrafos en las entrevistas que se anexan.
} 
masa que sólo se deja llevar, autos que no pueden avanzar, tumulto; cuerpos sudados, torsos desnudos, calor sofocante, falta de aire, falta de espacio, falta de cielo, hacinamiento; cintas rojas atadas a sombrillas y sombreros, banderas, camisas y remeras rojas por doquier.

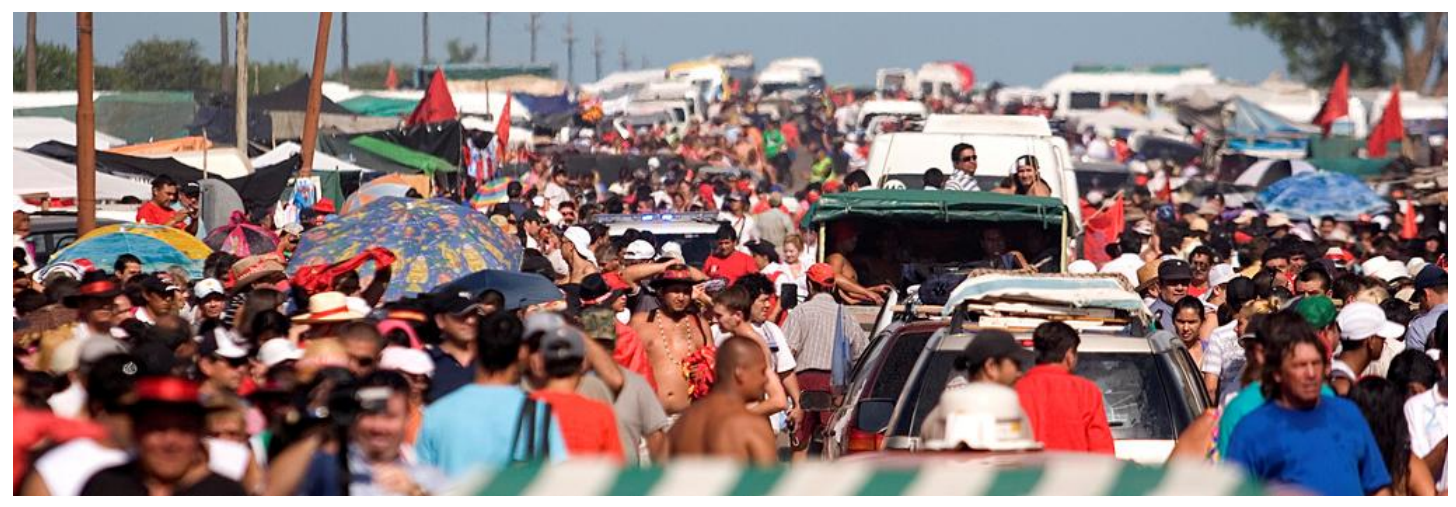

S/T. Guillermo Rusconi. Mercedes, Corrientes, 2011. Flickr del fotógrafo.

Pero al mismo tiempo que aparecen capturas mediadas por una importante toma de distancia del objeto fotografiado, que a simple vista se presentan como la prueba del desorden que alimenta la inevitable sensación de desborde; se evidencia también en las sucesivas imágenes que devuelve el visor del computador cómo por momentos los fotógrafos asumen también una mirada mucho más implicada y participativa.

En las imágenes subsiguientes se percibe que los fotógrafos caminan, se mezclan en la multitud para fotografiar. Y pese a lo dificultoso que resulta, en medio de la marea de gente, pararse en un lugar reducido a componer una foto, la experiencia de las sucesivas coberturas les otorga el conocimiento para ganar determinados espacios estratégicos con el fin de una captura más reflexiva.

De allí que más allá de la toma de la multitud, que siempre resulta necesaria para vender titulares por un lado y para dar cuenta de la inconmensurabilidad del fenómeno por el otro, así como del registro de los rituales claves por ser referenciales del acontecimiento (el saludo de los fieles a la imagen central de la divinidad en el santuario o la llegada de los gauchos peregrinos al lugar o la procesión con la cruz peregrina, etc.); las fotografías de los últimos años de estos autores se centran en mostrar momentos de intimidad devocional, en los que se incluyen tomas de muy corta distancia.

En esta línea, por su parte, los recortes y primeros planos ayudan a resaltar a cada uno de los sujetos y los objetos que implican y hacen a la conmemoración de esa gran masa a 
primera vista imprecisa, amorfa y tan dinámica que se presenta escurridiza al dominio de los encuadres.

Sin lugar a dudas, a menor distancia, las imágenes se conciben guiadas por el afecto que desborda en el primer plano, al modo de la image affection de Deleuze; se centran en los rostros y capturan miradas que dejan de manifiesto sus cualidades afectivas.

Para Deleuze la afección es entendida como el "efecto" de una imagen sobre quien la mira, "que envuelve e implica un afecto". En esta línea, el discurso afectado es aquel "que trata de salirse del canon de la no manifestación y la contención para desbordar" en la obra (Delgado, 2007: 229). En la construcción de la imagen ello implica un tratamiento particular de la composición visual (forma, color, movimiento) que tiende a exaltación de determinados valores plásticos en detrimento de otros (regulación de intensidad de los afectos ${ }^{204}$ ) sujeto a fines y condiciones de producción y recepción específicas.

Tal es el caso de Luz en tu mirada, la foto de Faccioli donde además podemos observar un trabajo cuidado de composición que aprovecha las condiciones atmosféricas para realzar los elementos y colores centrales de la imagen a través de la distribución de luz de fuente natural. En este caso la mirada de la niña y el perfil del rostro de la imagen del "santo" popular logran una perfecta iluminación y se alzan emotivas descubriéndose entre las diagonales de brazos cruzados de tonos rojos y azules.

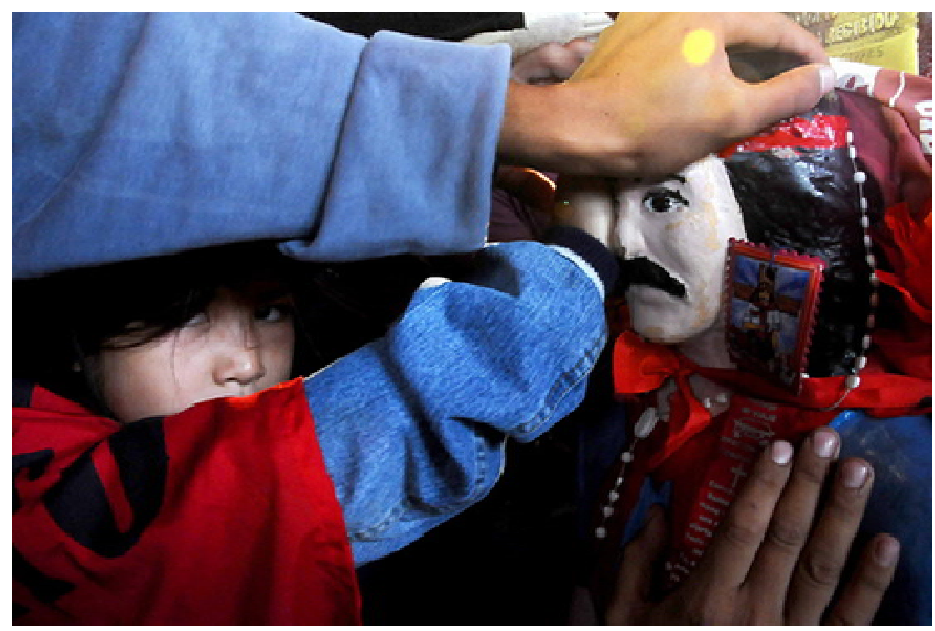

Luz en tu mirada. Juan Pablo Faccioli. Mercedes, Corrientes, 2008. Muestra Devoción. Imaginarios de fe en Corrientes. Inaugurada el 30 de diciembre de 2010 en Mercedes, Corrientes.

\footnotetext{
${ }^{204}$ Deleuze señala que la obra de arte es como "un ser de sensación". Se construye por "acordes de tonos o de colores que son los afectos de la música y o de la pintura (...) El artista crea bloques de preceptos y de afectos (...) El artista es presentador de afectos, inventor de afectos, creador de afectos, en relación con los preceptos o las visiones que nos da. No sólo crea su obra, no las da y nos hace devenir con ellos, nos toma como compuesto" (Deleuze, 1993:165-177).
} 
Desde lo técnico estas disposiciones y control de la luz le otorgan equilibrio a la composición. Cabe señalar que sobre todo el manejo de la iluminación, que permite el realce de determinados rostros, cuerpos u objetos y el ajuste de la temperatura del color, es uno de los recursos que resultan fundamentales para el despliegue de la poética del pathos que caracteriza a las imágenes de estas producciones.

Además esta estética se desarrolla por un fuerte "trabajo de rostrificación" (Olivera, 1996), que presenta in crescendo sentimientos, guiado por esa forma teatral patética que se recrea de manera repetitiva en cada toma con el fin de alcanzar máxima expresividad. Pero al mismo tiempo cada una de ellas ostenta una singularidad que se asienta en las condiciones particulares, los contratos preestablecidos entre fotógrafo y fotografiado, que signan el momento de la toma. También en este sentido pueden interpretarse las dos imágenes que se exponen en el siguiente apartado: Devoto, de Faccioli y S/T foto del hincha maradoniano de Rusconi.

\section{Formas de ver y dar(se) a ver desde poética melodramática}

De lo observado puede señalarse también que el acto fotográfico se concibe como un punto de encuentro de carácter único, un lugar de intersecciones y confluencia de pactos, un espacio donde conviven las ansias y los intereses de poseer el objeto que el fotógrafo se apresta a dar a ver y donde éste, que se precipita como poseedor, algunas veces se topa con que está siendo poseído, interpelado por ese objeto que de pronto irrumpe en la escena en su carácter de sujeto activo, demandando participación en el proceso de construcción de la imagen.

En la mayoría de las ocasiones, las fotos producto de esos "encuentros" en la trayectoria de fotografiar de Faccioli y Rusconi resultan siendo, como señala la prestigiosa fotógrafa argentina Adriana Lestido, las más potentes: "Las imágenes que tienen vida propia, son imágenes de unión, de dos energías (....) es la unión entre quien mira y lo mirado. Y eso implica una cercanía, una fusión con el otro" (Adriana Lestido en Colom, 2010). Se trata de una cercanía de corta distancia efectiva entre fotógrafo y el fotografiado y por ende también una mayor implicancia subjetiva entre ambos ${ }^{205}$.

${ }^{205}$ La mayoría de las imágenes de las festividades religiosas fotografiadas por Faccioli y Rusconi fueron logradas con una distancia focal muy corta: una lente de 35 o $40 \mathrm{~mm}$, nunca se opta por el teleobjetivo. Esto de alguna manera los lleva a estar ahi y tener un encuentro cuerpo a cuerpo, mirada a mirada, fotógrafo y fotografiado. 
De esta manera podríamos decir que los rostros que vemos en las fotos se construyen bajo un concepto que en muchas ocasiones, no en todas, responden a intereses compartidos. Así mientras el fotógrafo va detrás de los constructos dramáticos, teatrales, a veces estereotipados que demanda la empresa de la comunicación masiva, algunos sujetos de la festividad aprehenden y enfatizan esas formas tan atractivas para la prensa (se atavían con ropas alegóricas al "santo" popular, se exaltan en gestos y movimientos corporales específicos, exageran posturas) y se exhiben a fin de que se los perciba y puedan así ganar un espacio para contar y mostrar parte de su historia.

Tal el ejemplo de Devoto, la imagen de Juan José Boca de Colón de provincia de Buenos Aires, quien todos los años participa de la celebración en honor al Gauchito y encabeza en Mercedes la movilización de fe de su familia y de la agrupación tradicionalista a la que pertenece. Él con su vistosa vestimenta hecha a imagen y semejanza de la iconografía que hoy representa al Gaucho milagroso impone una presencia corporal que se distingue en la multitud y siempre capta la atención de las cámaras, entre ellas la de Faccioli que en 2008 lo registra con un rostro profundamente afectado.

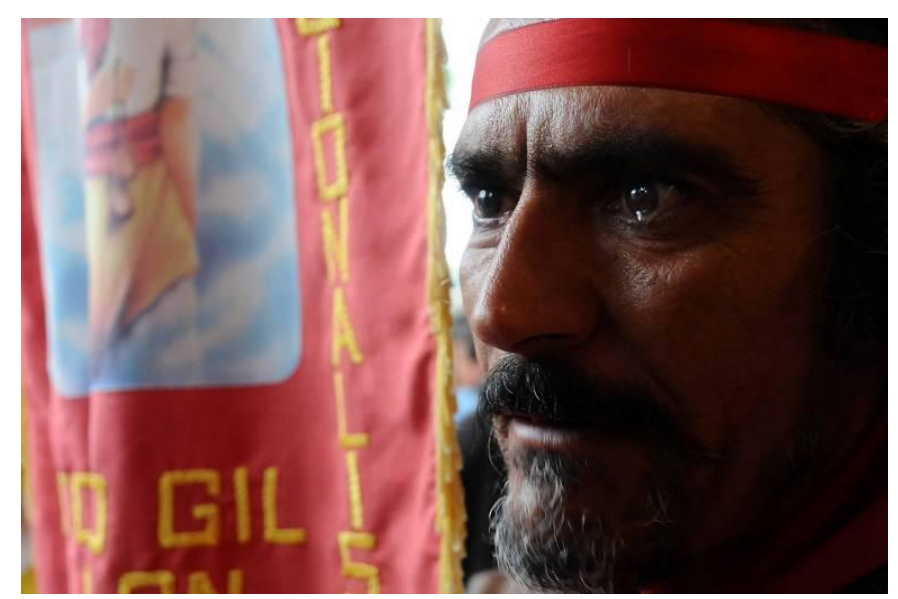

Devoto. Juan Pablo Faccioli. Mercedes Corrientes, 2008. Publicado en Agencia Corrientes, 8/1/2008

De ese modo el retratado se vale de la poética melodramática para darse a ver y también de algún modo proyecta su interés en el acto que determina la construcción de la foto. Lo relatado nos lleva a pensar en este punto cómo los sujetos retratados pueden ejercer influencia sobre la escena fotografiada y cómo el melodrama se transforma en un recurso preciado de expresión de demandas y de mediación de intereses en el momento del ritual y del acto fotográfico que lo re-crea como parte integrada a la festividad. 
No obstante hay que señalar que así como en algunos casos y circunstancias, quienes se perciben observados por la cámara, posan y pre-modelizan su imagen fotográfica, tal como teoriza Barthes (1989), cuestión que retomamos más adelante; es finalmente el fotógrafo quien goza de una posición de mayor "autoridad" y termina definiendo en la captura. Por eso las relaciones posicionales del acto de captura son siempre desiguales y ello no es un dato menor

En referencia a esa última "factura" de la imagen por parte del fotógrafo, si volvemos al caso del devoto, vemos que al realizar el retrato Faccioli decide excluir del encuadre la imagen de rostro de la iconografía del Gaucho Gil que aparece estampado en el estandarte que ocupa el punto de interés izquierdo de la composición y opta por guiar la mirada del espectador al rostro conmovido del devoto. Éste gana la escena en el punto de interés derecho. En él las lágrimas y la mirada penetrante se apoderan de sus rasgos, salen de sus contornos y desbordan la propia foto hasta conmover.

Hay allí una intención de generar conmoción que precede el disparo y por el otro un concepto que interpela a quien observa la fotografía a completar esa información que aparece recortada en un punto con la que ofrece el otro. Pero además hay una idea de proyección imaginaria entre el cuerpo del Gaucho Gil ausente, inscripto en el ícono y el rostro del devoto presente, que resulta altamente simbólico, performático y per-formativo en circunstancias convencionales específicas.

Ahora bien, pensar la dimensión per-formativa de las fotos implica observar cómo en tanto representaciones éstas portan valores específicos sobre la cultura ritual y religiosa que por su capacidad de síntesis (en la medida y el alcance de su circulación y en un contexto y dentro de códigos específicos, por ejemplo en el marco de un altar, inmerso en una práctica ritual, etc) pueden incidir en la realidad contribuyendo a los procesos de identificación y a actuación particulares.

Asimismo esta forma constructiva de la imagen se liga fuertemente a la retórica del melodrama no solo desde la simplificación formal y lo teatral, sino también desde su apoyo en las convenciones sociales, los estereotipos, que permiten apelar directamente a los sentidos y conseguir la asimilación rápida del público de su contenido. Esa señalización reiterada de un contenido no está ajena al gusto popular, negocia con él. En este sentido, la apelación a esa retórica genera familiaridad e identificación en el espectador.

En circunstancias similares a los momentos de captura narrados en el caso de Faccioli, en la celebración del 8 de enero de 2008, Guillermo Rusconi se encontró con un hincha maradoniano (simpatizante del jugador de fútbol argentino Diego Armando Maradona) quien 
realizaba un ritual de amplio despliegue emotivo en el santuario. Empapado en lágrimas y en vino, se movía aferrado en una mano a la pequeña imagen del Gauchito que le servía de amuleto y en la otra a una botella de la que bebía y con la que embebía la imagen central que preside la tumba del "santo" popular del paiubre correntino.

De esta manera el hincha devoto se exponía frente a la cámara de Rusconi por un espacio de tiempo que le permitió al fotógrafo no sólo realizar una serie de imágenes (una de ellas es expuesta en el capítulo anterior) sino también entablar una breve charla con el fotografiado. Éste le comentó que llegaba desde el Gran Buenos Aires para agradecerle al Gauchito "por haberlo salvado a Maradona cuando estaba tan delicado de salud por el consumo de drogas". Así relató el fotógrafo durante una muestra en la que se exhibía una de las fotos de la serie, en cuya inauguración participamos en diciembre de 2010.

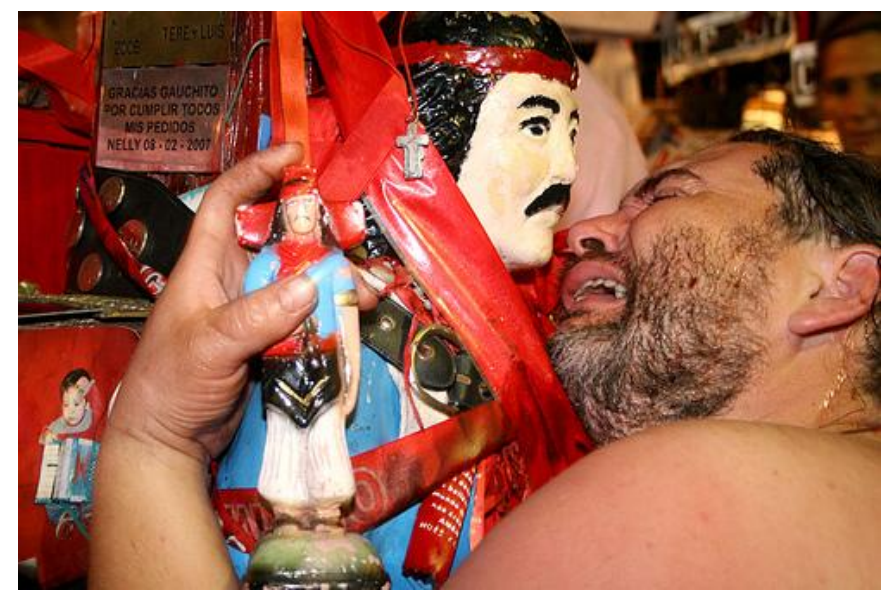

S/T. Guillermo Rusconi. Mercedes, Corrientes, 2008. Muestra Devoción. Imaginarios de fe en Corrientes. Inaugurada el 30 de diciembre de 2010 en Mercedes, Corrientes.

Del relato del fotógrafo y lo observado en la serie de capturas, puede interpretarse que el intercambio entre fotógrafo $\mathrm{y}$ fotografiado se generó mediado y profundamente influenciado por el gesto, figura de la acción, materia semántica del cuerpo a través del cual el sujeto se hace visible, participa del ritual y de la comunicación (Breton, 1999). He aquí la forma de expresión melodramática del dramatismo religioso que penetra las bases de las prácticas de religiosidad popular y se (re)crea en la foto. Esa expresión trabaja justamente para vencer la represión (Brooks, 1976). Es decir esa restricción (que regula el movimiento afectivo/controla las emociones) que cede cuando la exacerbación de los sentimientos (impulso) traspasa los límites que impone la norma hasta el momento pre-establecido (Williams, 1980). 
Es en este sentido que el melodrama supone más que un género un modo de narrar y de sentir revolucionario que permite expresar y visibilizar las demandas de los sectores populares que no encuentran cabida en el campo del discurso de lo permitido. De ese modo la forma "afectada" melodramática desde el ritual y su recreación fotográfica en el terreno de lo masivo nombra y le da lugar a "lo popular", sin que estas relaciones impliquen un lazo popular-masivo sin conflicto. Ya que pensar el status de co-productores que adquieren los sectores populares de las representaciones analizadas no significa dejar de pensar en los procesos de reproducción de la dominación cultural y simbólica de los cuales los actos fotográficos no escapan, en tanto están atravesados por relaciones de poder y desigualdad.

No obstante, es significativo concebir los actos fotográficos como espacio de articulaciones dialógicas donde tanto productores y co-productores marcan los textos (Rodríguez, 2010), anidando en ese gesto de intersecciones, la capacidad de quebrar y redefinir el discurso de lo socialmente legítimo.

\section{El acto fotográfico como lugar de proyecciones identitarias}

Este trabajo además de detenerse en el análisis de imágenes en relación a los relatos relevados de las conversaciones entabladas con fotógrafos también se construye a partir de notas de campo de observación en la festividad central del Gaucho Gil. Allí también se condensan, quizá de forma fragmentada y hasta incompleta por lo que tienen de estímulo sensorial y provocación de sentimientos, las experiencias de acompañamiento de la tarea de los fotógrafos en la cobertura de dicha conmemoración ${ }^{206}$.

En este marco, pasando de la tercera a la primera persona en el relato, comparto aquí algunas inquietudes surgidas de la observación de un acto fotográfico en contexto de la festividad religiosa del Gaucho Gil, a modo introductorio de las reflexiones que siguen.

Era el ocho de enero de 2011 cuando junto a uno de los fotógrafos caminaba entre la multitud que se había congregado en el santuario ubicado a la vera de la ruta nacional 123 para rendirle tributo al "santo" popular. Allí, en el día central de la fiesta presencié un intercambio producido entre este fotógrafo y un fotografiado que aquí traigo a colación.

El fotografiado era un hombre de aproximadamente 30 años de edad, de contextura delgada y estatura mediana, que en medio del calor sofocante del mediodía en el predio festivo lucía un tatuaje de espalda completa con la iconografía del Gauchito. Era realmente

\footnotetext{
${ }^{206}$ Agradecemos también las experiencias compartidas con los fotógrafos Carlos Ayala y Abel Fleita en el marco de estos trabajos de campo los días 8 de enero de 2010 y 2011.
} 
llamativo ver aquella gran imagen impresa en su torso desnudo paseándose entre la multitud. El fotógrafo pidió permiso para tomarle una foto y éste accedió y posó. Luego el devoto solicitó ver la foto y reclamó que le sacara otra. Se repitió el procedimiento y al volver a revisar la nueva imagen, esta vez sí se vio a gusto. Preguntó detalles sobre el espacio y fecha de su publicación y dio su consentimiento.

Particularmente, las acciones del fotografiado, de verse a sí mismo, gustarse o no gustarse, imaginarse de determinada manera y no otra en función de deseos y expectativas puestas en la difusión (que en este caso serían en un diario de tirada provincial), así como en la posibilidad de perpetuación de un concepto visual de sí mismo y decidir volver a posar, abre la pregunta que aquí formulo sobre los modos de construcción de la "imagen de identidad" -idea que desarrollamos más adelante- y que se activa en el acto fotográfico.

Esta instancia experiencial significativa y otras observadas en las que son los fotografiados los que plantean estrategias de seducción (es claro el caso del Devoto retratado por Faccioli) se muestran y buscan llamar la atención de los fotógrafos, como buscando ser fotografiados e incluso interpelando a través de un saludo a la cámara (como se ve en la foto de 2011 de Rusconi del joven montado a caballo) ; o bien otros casos en las que los fotografiados al sentirse interpelados por la cámara espontáneamente y automáticamente se “constituyen en el acto de posar" (Barthes, 1989); o todo lo contrario se corren de la dirección del objetivo negándose ser retratados (que en el caso del Gauchito Gil casi no se da porque la mayoría está altamente predispuesta a ser fotografiada), me llevaron a cuestionar: 1) la distancia "objetiva" que se planteó históricamente entre fotógrafo y fotografiado como uno de los atributos más valorados del registro fotográfico ${ }^{207}$, 2) la consideración de lo fotografiado como mero objeto fácilmente cosificable y 3) la idea de pasividad o alienación que adoptan los sujetos retratados ante la cámara ${ }^{208}$.

Por el contrario, los actos observados me llevaron a cuestionar esas concepciones desde la noción de subjetividad de la toma, donde observo que los sujetos retratados pueden ejercer gran influencia sobre la escena fotografiada. Es decir, así como el fotógrafo, que en tanto autor posee cierta "autoridad" en la modelización de la imagen -marcando su superioridad en las relaciones de poder de la captura- el fotografiado en ciertas instancias

${ }^{207}$ Esta objetividad ha sido ampliamente discutida desde diversos campos de las ciencias humanas a partir de los años sesenta y al respecto los diferentes abordajes acordaron en concluir que la fotografía a la vez que es testimonio/documento también es artificio/creación.

${ }^{208}$ Esto constata la posición activa de los fotografiados y en este contexto la tesis de la manipulación, como afirma Ford, es solo concebible como utopía (1982). Por otra parte, en la línea de los planteos de Barbero, ello implica comprender que si bien sus inicios la cultura de masas responde a los intereses de homogeneización religiosa y centralización política, también "abre a las clases populares el acceso a la cultura hegemónica" y "les da a esas clases la posibilidad de hacer comunicable su memoria y su experiencia" (Barbero, 1998: 133). 
actúa proyectando su interés en el acto que determina la construcción de la foto. Sin olvidar que también dejan sus marcas las circunstancias y las condiciones socio-históricas de producción, desde esta perspectiva el fotografiado adquiere status de "co-productor".

Ello, a su vez, me condujo a reflexionar sobre la cuestión de proyección identitaria en el acto de producción de las imágenes, desde la acción misma de fotografiar. En este sentido se pensaron también las relaciones entre las nociones de imagen acto e imagen identidad. Esto implica comprender cada fotografía cobra cuerpo y sentido sólo al actuarse siendo la contextualización el proceso mediante el cual los performers (fotógrafos y fotografiados) incluyen sus marcas para que las imágenes que surgen tengan un determinado sentido para el público.

A este proceso es al que denomino per-formar identidades desde el acto fotográfico y en contexto de prácticas de la religiosidad popular contemporánea ${ }^{209}$. Se trata de una escenificación fotográfica dentro de las limitaciones de las condiciones de producción que posibilitan lo que llamo proyección de una determinada imagen y no otra de la realidad y de sí mismo. Hablo de una imagen que además se produce, más allá de lo azaroso del acto fotográfico, por la influencia de marcos mentales a partir de los cuales los intervinientes plantean su concepción del mundo.

Dicho proceso refiere al caso del fotógrafo que través del recorte fotográfico proyecta, en la medida de lo que el tiempo- espacio y lo efímero del acontecimiento lo permite y sobre condiciones precedentes que estructuran las codificaciones posibles, su intencionalidad, su modo de ver sobre lo representado; pero también del fotografiado que puede incidir, dependiendo de las circunstancias, y por ende intervenir en la escena fotografiada.

\footnotetext{
209 Ver Barrios, Cleopatra (2013) “Actuar, fotografiar, per-formar identidades en y desde prácticas de religiosidad popular en la provincia de Corrientes", en Giordano, M; Sudar, L; Isler, R (edits) Memoria e imaginario del Nordeste Argentino. Prohistoria, Rosario. pp.89-119.
} 

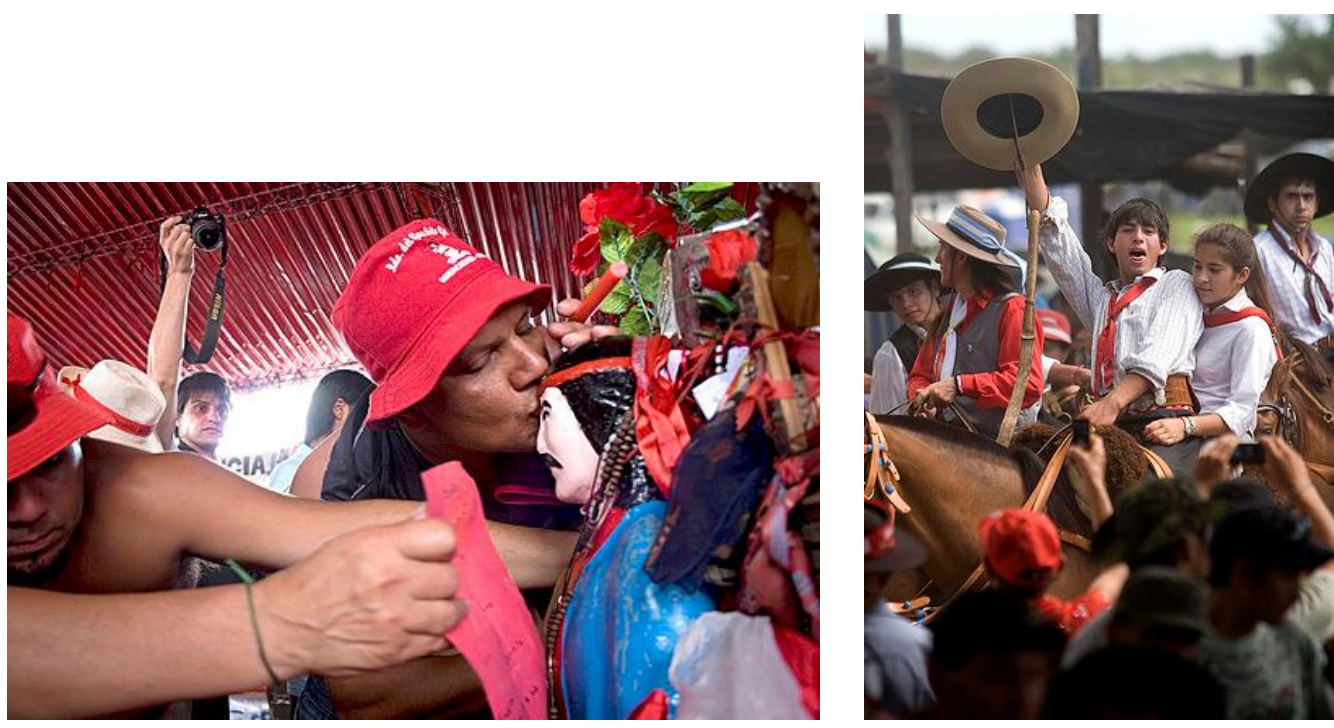

Performers en instancias de producción. En la primera imagen (de Guillermo Rusconi) Juan Pablo Faccioli durante la acción de fotografiar. En la segunda (también de Rusconi) los fotografiados en pose pre-determinan la escena fotografiada. Fotos 2011. Col. Rusconi

Al respecto, Faccioli y Rusconi, señalaron que en muchas oportunidades se vieron persuadidos por determinados personajes que sobresalen en medio de la multitud por valerse de una disposición actitudinal-emotiva o un vestuario singular e incluso por salir al encuentro de las cámaras con clara intención de inscribirse discurso de la imagen.

Guillermo Rusconi le atribuye también a esta puesta en escena que montan los propios devotos que la festividad del Gauchito sea "fotogénica". Más allá de la simbología por doquier y el rojo intenso "que inunda todos los espacios", el fotógrafo insiste: "Hay expresividad en la gente; tenés hasta los que van lookeados especialmente para la ocasión, por ejemplo vestidos como el Gaucho Gil” y recalca que la gente del lugar en general se muestra "orgullosa" de ser fotografiada. Lo que plantea de entrada un intercambio y diálogo fotográfico intenso entre fotógrafos y retratados.

Entre los ejemplos más significativos de aquellos retratados que interpelan/ seducen a la cámara y que pudo observarse claramente en el intercambio con estos fotógrafos, se puede citar el caso de don Brizueña, uno de los devotos de la provincia de Buenos Aires "lookeado" -en término de Rusconi, con pilchas gauchas, barba larga y tupida y que siempre se lo ve portando la imagen de un Gauchito de bulto pegado a una cruz de casi mediana estatura humana también muy imponente ${ }^{210}$. Otro personaje es don Augusto Cabrera, el referente de la agrupación los Gauchos de Antonio Gil ${ }^{211}$.

${ }^{210}$ Un retrato de Brizueña se reproduce en el Capítulo3.
${ }^{211}$ Algunas imágenes de él se ven en el Capítulo 3 
También entra en esta lista personajes fotogénicos el caso del devoto Juan José Boca de Colón, de la provincia Buenos Aires. Una imagen de este peregrino es la que fue tomada por Faccioli y se ve en apartado anterior bajo el título de Devoto. Al ser consultado sobre el personaje y el momento de esta captura Faccioli en primer lugar recalca cómo lo impactó la figura del gaucho que "construye una imagen de sí", casi a imagen y semejanza del gaucho de los milagros para darse a ver, en el entorno de la fiesta y luego admite que la propia predisposición del retratado hace que su captura se haya construido de una forma "colaborativa".

Faccioli al volver a revisar la foto recuerda:

\begin{abstract}
“Acá él (fotografiado) percibe mi cercanía, observa que yo voy buscando el encuadre y en ese intercambio de percepción parece que el entendió que me ponía de de costado y no de frente y de algún modo, me habilita. Parecería que implícitamente me decía 'hacé y buscá lo que necesites" Incluso pude trabajar el triángulo de luz en el pómulo del rostro que es un recurso del retrato de estudio y en ese contexto muy ambiciosamente buscado se logra por la predisposición del fotografiado (Faccioli, 2013).
\end{abstract}

También se ponen de relieve en el seno de la festividad diferentes casos de hombres y mujeres, que movilizados en torno a agrupaciones tradicionalistas de jinetes, músicos o bailarines folclóricos creadas para rendirle tributo al "santo" popular, adoptan y exhiben orgullosos en su honor y ante las cámaras: bombachas, camisas, chalecos y pañuelos en tonos rojo y negro especialmente preparados para la ocasión. De este grupo, pueden destacarse en las series de Faccioli y Rusconi distintos casos donde los retratados miran y saludan a la cámara. Un ejemplo relevante constituye el retrato que sigue sobre el cual Faccioli comenta que, no en uno sino en varios momentos de la festividad siguió al joven para realizarle la foto y que éste se dio cuenta y lo dejó acercarse y posó durante varios minutos para posibilitar la captura. 


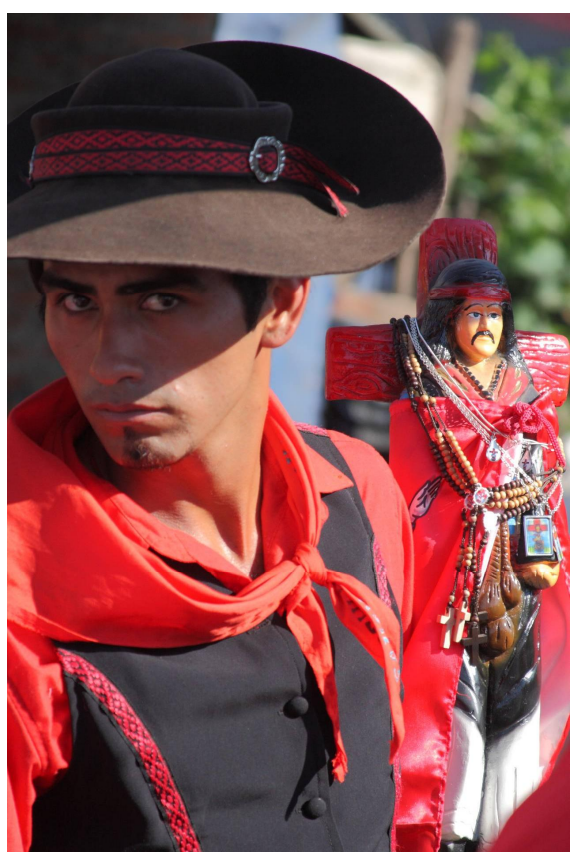

Performance de producción. Fotografiado se imagina, crea una imagen de sí, configura una "imagen identidad” en co-producción con el fotógrafo. Mercedes, 2012. Juan Pablo Faccioli.

Estas situaciones llevan a confirmar lo que Buxó i Rey, plantea cuando dice que "la gente no simplemente se deja tomar una foto, sino que actúa activa y retóricamente construyendo imagen de sí para la cámara", a través de estrategias de exhibición, presentación, escenificación de un "yo cultural”; y "no es un simple objeto natural (...) esencial (...) preexistiendo para ser modelada, ni un producto estable de uno mismo, sino que se trata de un yo inestable y experiencial según la variedad de situaciones y las relaciones de poder" (Buxó i Rey, 1998: 182).

Asimismo, este recorrido de la instancia de performance fotográfica- que cobra sentido al actuarse- invita a discutir la noción de "imagen de identidad" (Buxó i Rey, 1998) y los diversos modos en que la dimensión identitaria se manifiesta en el acto fotográfíco. Esto sucede no sólo al tiempo del ejercicio de capturar de determinada forma y no otra y con ello clasificar, catalogar a lo fotografiado en relación con ciertos esquemas reguladores identitarios, a su vez influenciado por las limitaciones circunstanciales, así como de su técnica y los regímenes de visibilidad establecidos, sino también al tiempo que el fotografiado se imagina y se crea así mismo para los demás.

La imaginación de un "yo cultural" por parte del devoto o participante de la festividad se da al ser interpelado por la cámara porque toma conciencia que es objeto de una mirada con proyección social. Esa conciencia lo obliga a darse a ver, "entregarse" o a resguardarse introvertidamente, no mostrarse, al modo que lo hacían los campesinos tímidos descriptos por 
Bourdieu (2004) en el Baile de los Solteros, ritual de los bailes de Navidad en la comunidad de Bearne en Francia. Todo lo contrario sucede en el marco de una festividad tan fotografiada como la del Gaucho Gil, donde buena parte de la vivencia transcurre en las pantallas. En este contexto, los participantes no encuentran inconvenientes en "ofrecer el cuerpo como espectáculo" y como correlato "aceptar exteriorizarse" teniendo una "conciencia satisfecha de la propia imagen que se entrega a los demás” (Bourdieu, 2004:117).

\section{Notas finales sobre fotografía, melodrama, religiosidad y adscripciones} identitarias

Recapitulando, hasta aquí hemos visto cómo el fotoperiodismo contemporáneo, en general, y aquel ligado al registro/documentación de prácticas ligadas a la religiosidad popular, en particular se ha integrado de lleno en el proceso de (re)creación de la estética melodramática que "parte de la mirada pero apunta a las entrañas" (Brodsky, 2009) convirtiéndose en un verdadero espacio de dramatización y poetización.

Pero tal como lo sostienen varios autores, el melodrama ha devenido en algo más que una estética, ética, estrategia y preferencia para terminar conformando, sobre todo en Latinoamérca en "una matriz de la imaginación teatral y narrativa que ayuda a producir sentido en medio de las expresiones cotidianas de los individuos y los grupos sociales (....) una matriz epistemológica alternativa que atraviesa toda la época moderna" (Herlinghaus, 2002: 22-23).

Bajo esa matriz se ha configurado la sensibilidad y la afectividad que caracteriza a la modalidad de narrar, contar y mostrar contemporánea y a la que se adscribió la fotografía, que desde nuestro parecer y focalizados en el caso de análisis se presenta como un espacio de producción y reproducción de imaginarios de indagación clave en tanto que:

-visibiliza problemáticas políticas y sociales tales como el horror de la guerra, el hambre, la pobreza o el terror de las dictaduras, etc.; así como da a ver un carácter complejo al entramado de la realidad sociocultural contemporánea con su diversidad de prácticas y la emergencia de actores, de sujetos fuertemente personalizados, rostrificados;

-moviliza al espectador en torno a esos temas gracias a que se apoya en una forma fuertemente codificada y altamente performático y per-formativo en circunstancias convencionales específicas, que encierra una carga simbólica que activa su función persuasiva $\mathrm{y}$ 
-articula en su construcción una trama compleja de vivencias, demandas, intereses experiencias de encuentros entre fotógrafos $y$ fotografiados $\mathrm{e}$ intersecciones de temporalidades diversas que nos permite pensar dialógicamente los procesos de subjetivación, así como las pujas y negociaciones por el establecimiento del sentido y la fijación de las identidades culturales involucrados en ella.

Ello nos da la noción del melodrama fotográfico en general y de la religiosidad popular correntina en particular, como configuración heterogénea porque, al modo del melodrama de telenovela analizada por Martin-Barbero, "recupera las anacronías al interior de un discurso que revuelve las más nuevas tecnologías (...) con los dispositivos de narración y reconocimiento más tradicionales e incluso arcaicos" (Martin-Barbero, 1992:4). Pero asimismo nos conecta con la idea de una construcción puente, de mediación, no exento de disputas y/o luchas por la significación en tránsito. En este sentido el peso de fuerzas desiguales en relación hace que muchas veces una retórica que contribuye a visibilizar, conmover y guiar a una toma de posición favorable en torno a los sectores marginados, muchas veces concluye abonando la indiferencia, a causa de la hipervisiblización apremiante que estigmatiza y banaliza realidades culturales tan complejas.

Lo expuesto abre la pregunta sobre los alcances y limitaciones que presenta esta reflexión y exige indagar aún más en la concepción de la vinculación de lo masivo y lo popular como lugar de disputas y negociaciones donde las relaciones de desigualdad y dominación son claves en la determinación de las pautas de visibilización y ocultamiento de imágenes que rigen una época y situación determinada (Martin-Barbero, 1998; Hall, 2003); siempre entendiendo la dominación no como "una imposición del exterior" sino como proceso mediante el cual la clase que domina lo hace "en la medida en que representa intereses que también reconocen de alguna manera como suyos las clases subalternas"212 (Martin-Barbero, 1998: 84).

Por otra parte, de lo analizado de los actos fotográficos y las proyecciones identitarias ligados a ellos en el marco de la festividad del Gaucho Gil, podemos concluir que las imágenes en general y las re-presentaciones fotográficas en particular - en sus instancias de

\footnotetext{
${ }^{212}$ Esta noción de ida y vuelta dentro de un mismo cuerpo social como plano donde se suceden negociaciones y pujas por el sentido entre sectores dominantes y populares rechaza la idea de la existencia de una cultura y una no-cultura, de imposición externa de los dominantes y de alienación interna de los dominados. Y plantea de lleno la problemática en función del concepto de hegemonía, entendida como "proceso vivido", dice Martín Barbero, "hecha no sólo de fuerza sino también de sentido, de apropiación del sentido por el poder, de seducción y de complicidad" (Martín Barbero, 1998: 84). Ello coincide con el planteo de Thompson, cuando en sus reflexiones sobre los motines de subsistencia ingleses del siglo XVIII se esmera en demostrar "cómo la hegemonía no se impone (o se discute) sencillamente, sino que se articula en el trato cotidiano de una comunidad..." (Thompson, 1995: 387).
} 
producción, circulación y consumo- constituyen un componente fundamental del acto comunicativo a partir del cual los propios rituales cobran sentido y se re-producen.

Las imágenes circulantes, ancladas y permanentemente actualizadas en la memoria colectiva e in-visibilizadas según regímenes de visibilidad específicos, van construyendo los marcos mentales desde los cuales las personas se imaginan y reproducen imágenes de sí. Estas imágenes modelan los esquemas de estructuración y las modalidades de dar a ver que reproducen las fotografías. Es decir, afectan los modos de seleccionar, clasificar una imagen material visual para su publicación/ difusión pero previamente también influyen en los modos de componer imágenes por parte de los fotógrafos y las maneras en que los fotografiados al ser interpelados por una cámara construyen una imagen de sí y de sus grupos de pertenencia para proyectarlas a los demás a través de la fotografía.

Ello nos lleva a entender en relación al análisis de las fotografías específicamente que el abordaje de la foto como unidad aislada de sus contextos de producción, circulación y consumo no cobra tanta relevancia como la reflexión sobre su lugar y forma de intervención desde esas instancias en los modos de producción y regulación del sentido en/sobre los rituales. De allí, resulta relevante la consideración de la foto como parte del acto comunicativo desde la dimensión procesual y performancial. Es decir, entenderla como imagen-acto que se construye inscripta en una situación referencial determinada y con un efecto pragmático, regulando incluso la reproducción y la adscripción de estereotipos identitarios, así como la difusión de informaciones nuevas a través de la imagen material visual.

En términos generales, la fotografía puede entenderse como performance, como imagen-acto porque cobra existencia y sentido al actuarse. Es el espacio del estar allí del fotógrafo para per-formar la realidad y señalar que algo está ocurriendo; así como de pose, de puesta en escena en muchos casos del fotografiado que participa de esta forma en la construcción de la imagen.

A la vez, estas instancias dan cuenta que más allá del "efecto de realidad" que plantea el acto fotográfico como forma de presencia, donde el fotógrafo se plantea como testigo de lo que ve, la escena fotográfica también evidencia su carácter constructivo en la necesaria intervención ideológica de los performers que a partir de operaciones de interpelación diversas hacen posible una toma y no otra. Siempre hay alguien que opera e interviene ideológicamente para lograr ese "efecto de realidad". Además, estas operaciones se encuentran inmersas en dinámicas institucionales y de grupos sociales (la Iglesia, el Estado, los medios masivos, el mercado y el consumo, la familia, agrupaciones de devotos diversos, 
etc) donde rigen normas que inciden en las formas de fotografiar y qué fotografiar, cómo mostrarse, darse a ver y qué mostrar.

Todo ello evidencia cómo la fotografía se configura a partir de densas capas de articulaciones/des-articulaciones y re-articulaciones de sentido, como un espacio de conexiones, encuentros, intersecciones que si bien intenta suturar las diferencias adscripto a un intento de unidad de sentido, por su naturaleza de texto abierto deja traslucir sus fracturas en las totalidades con la emergencia siempre posible en su seno de significados diversos.

En este contexto, la imagen fotográfica según los usos que de ellas hagan los sujetos que las manipulan, así como posee la capacidad de ocluir también posee la aptitud para develar y dar cuenta de la heterogeneidad de las prácticas socio-culturales; pero una heterogeneidad que se concibe compleja y conflictiva atravesada por la operación del poder y la lucha por políticas de ocultamiento y visibilización, en definitiva por la dominación simbólica. 


\section{A MODO DE CONCLUSIÓN:}

\section{Re-presentación, performatividad y re-politización de la mirada}

Esta tesis tuvo como objetivo analizar los modos en que las fotografías del Gaucho Gil participan activamente en la re-creación y re-significación de la festividad del "santo" popular y en la reconfiguración de representaciones de la religiosidad correntina; asimismo, se propuso comprender a estas imágenes como espacios de articulación de la cultura popularmasiva y de construcción de memorias e identidades.

Estos planteos fueron trazados en relación a trayectos profesionales particulares con prácticas de fotografiar y re-presentar festividades religiosas correntinas, a indagaciones previas realizadas en ese campo y, como ya se dijo, también partieron de las inquietudes en torno un conjunto de fotografías del Gaucho Gil tomadas entre 1999 y 2013 por Juan Pablo Faccioli, Guillermo Rusconi, Eduardo Longoni, Estela Izuel y Marcos López y, de observaciones de actos fotográficos en la festividad central del "santo" popular en Mercedes, Corrientes.

Algunos interrogantes iniciales buscaron entender de qué modo y a partir de qué estrategias las fotografías construyen representaciones (hegemónicas y/o alternativas) de las prácticas religiosas; en relación a qué textos y en qué contextos, cómo estas representaciones fotográficas proliferan en vinculación a los trabajos de la memoria; cómo se construyen los actos fotográficos y de qué modo se tejen relaciones de poder entre fotógrafos y fotografiados en esos ámbitos y, finalmente, de qué modo estos actos de ver, fotografiar y re-presentar participan en los procesos de desestabilización de memorias e identidades y en la recreación de las propias prácticas religiosas y/o prácticas de sacralización que se construyen en torno a la figura del Gaucho Gil.

\section{La vida de las imágenes y la transitoriedad de las categorías y nominaciones}

En la dirección de las preguntas de investigación desarrollamos la problematización del tratamiento de la fotografía en relación a las representaciones sociales, las prácticas sociales y discursivas, que nos llevó a revisitar debates instalados por algunos autores en las ciencias sociales a lo largo del siglo XX a la actualidad. El mapeo de las discusiones y lecturas en torno a las definiciones de la fotografía nos condjujo a enfatizar la "transitoriedad histórica" de las categorías conceptuales. Esta cuestión resultó central en la investigación porque nos permitió mostrar cómo las fotografías del Gaucho Gil van adquiriendo diversos 
sentidos según las posiciones de los sujetos que las miran, las manipulan y las invisten de sentido en una situación contextual e histórica específica. Sólo desde allí fue posible desentramar los diferentes roles que los devotos, fotógrafos, medios de comunicación y/o simpatizantes vinculados al mundo de este "santo" popular le adjudican a las fotografías, haciéndolas partícipes de los modos de producción y re-producción de las representaciones de la religiosidad correntina.

En este sentido, el abordaje relacional y transdisciplinar de las imágenes, vinculado tanto a sus dimensiones representacionales iconográficas como a las instancias pragmáticas de los actos que las producen y las modalidades de circulación y consumo, confirmó una posición transversal que la tesis sentó desde el principio y que tiene que ver con entender a las fotografías no como meras ilustraciones de los textos lingüísticos, ni registros "fieles" de lo real, sino como formas de producción de sentidos. En otras palabras, insistimos en que las fotografías -desde lo que dan a ver y lo que ocultan, los modos en que lo realizan, así como las formas en que son apropiadas y re-significadas en instancias de producción y consumo cultural- son formas simbólicas atravesadas por la construcción de las miradas que movilizan y legitiman ciertas "visiones de mundo".

Llegado a este punto, vale señalar que hasta paradojalmente en un estudio que intenta poner en discusión la estabilidad de ciertas categorías y nominaciones en relación a las imágenes, se hizo necesario adoptar algunas para hacer inteligible el pensamiento. En ese sentido, desde el propio título de esta investigación se realzó el término re-presentación fotográfica porque, atendiendo al punto de vista adoptado, las particularidades de las materialidades trabajadas y su contexto, esta categoría se presentó productiva para dar cuenta de la doble dimensión de representación-presentación que las fotografías del Gaucho Gil asumen en el marco de las prácticas sociales y discursivas, religiosas y extrarreligiosas. La representación hace mención a los sentidos sociales e ideológicos que estas imágenes entraman en tanto "concepciones de mundo"; mientras la presentación remite a cómo las fotos se presentan ante la mirada, con qué especificidades materiales, formales, expresivas visuales. Consideramos que en la intersección de estas dimensiones reside gran parte de la capacidad de interpelación al espectador que las fotografías del Gaucho Gil poseen, a lo que sumamos la consideración de su carácter polisémico que, como sucede con todas las imágenes, le posibilitan a estas fotos no sujetarse a una pretendida unidad de sentido y articularse a diversas cadenas de significaciones en su circulación.

En el afán de discutir la desestabilización de las categorías que surge de la complejidad de nuestro objeto de estudio, la tesis también sirvió para debatir la atribución de 
dimensiones identitarias fijas e inalterables a las imágenes fotográficas del Gaucho Gil, sobre todo atendiendo a su movilidad por diferentes contextos y su vinculación con distintos textos.

En este sentido, se analizaron algunas nominaciones que se construyeron desde los anclajes de la palabra con el fin de controlar la proliferación de los sentidos de estas imágenes. En ese trayecto, concluimos que categorías tales como "documentos", "artefactos culturales", entre otros que se construyeron sobre la base de las cualidades y atributos de las imágenes y su modo de relación con lo real -más o menos "objetiva", sometida a mayor o menor manipulación- no pueden considerarse determinadas o estabilizadas. Y lo mismo sucede con aquellas identidades nominales o "etiquetas" que las personas adosan a las imágenes para puntualizar/resaltar además otros aspectos de lo que ellas dan a ver, por ejemplo cierto asunto como podría ser la referencia a "religión", "religiosidad popular" o "prácticas religiosas"; o cierta localización como "correntina y/o argentina".

En relación a la cuestión, observamos a lo largo de estas páginas que las imágenes del Gaucho Gil así como pueden aludir a dichas categorías, asuntos y localizaciones, también en otras instancias de producción/circulación y consumo muestran algo distinto; es decir, activan otras interpretaciones.

Así, vimos por ejemplo cómo varias fotografías de Guillermo Rusconi o Juan Pablo Faccioli cobraron en primer lugar valor de registro "objetivo" de un acontecimiento para indicar como documento fotoperiodístico lo que "ha sucedido" -en términos barthesianos- en las páginas de los diarios; y de qué modo las mismas imágenes fueron re-introducidas a través de una muestra fotográfica en espacios de exposición cobrando nuevo valor, resaltándose incluso desde las propuestas curatoriales la interpretación subjetiva de los fotógrafos en torno a lo retratado .

También apreciamos cómo el retrato del Gaucho Gil de 2008 de Marcos López fue expuesto primero en una galería de arte y se presentó desde la interpretación de los que conforman el "mundo del arte" como "fotografía artística"; para luego ser valorada en un contexto diferente como una "imagen fetiche", imagen venerable, a raíz de la circulación y la apropiación realizada por diferentes actores, incluidos los devotos del "santo" popular.

En definitiva, las imágenes del Gaucho Gil en su vida socio-semiótica prolífica -como bien indica Caggiano (2012) en su reflexión en torno a otro corpus- plantean diversos tipos de relaciones con las categorías. La mayoría de las imágenes que re-visionamos aquí no se dejan contener por las categorías, las desafían desde los diversos contextos de circulación y consumo; sin embargo, otras imágenes según indican algunos relatos surgen para sostener algunas categorías. Esto último sucedió con algunas "vistas" de la ciudad de Corrientes que, 
según comprobamos en nuestra indagación de álbumes y archivos, durante el siglo $\mathrm{XX}$ contribuyeron a construir un imaginario de "progreso" y "ciudad moderna" afín a determinados proyectos políticos nacionales y provinciales; y junto a ellas también cumplieron una función similar las vistas generales de procesiones y misas religiosas católicas que construyeron la representación social de Corrientes como "provincia católica".

$\mathrm{Al}$ respecto, podemos señalar que las categorías e identidades nominales atribuidas por el trabajo del lenguaje en relación a los modos de mostrar/dar a ver/ u ocultar de las imágenes - con los desfases propios que hay entre las formas de construir sentido de las imágenes y las palabras- funcionaron y aún funcionan catalizando formas de jerarquización social. Se trata de modos de representación que los grupos sociales construyen de sí en vinculación a los otros desde la manipulación de ciertos materiales de la cultura, en este caso de imágenes materiales visuales vinculadas a otros textos. De allí, resultó relevante para esta tesis profundizar en la indagación sobre el rol de las re-presentaciones fotográficas del Gaucho Gil en la construcción y de-construcción de memorias e identidades sociales en vinculación a los sistemas de clasificación, anclajes del lenguaje, las prácticas sociales y dentro de formaciones históricas discursivas específicas.

\section{La producción de imágenes del Gaucho Gil y el campo religioso} heterogeneizado

El desafío de indagar qué papel juegan las imágenes del Gaucho Gil en las formas de imaginación social (Appadurai, 2001) en su pasaje por diversos campos como el periodismo, la documentación o el arte, también nos llevó a investigar cómo esas imágenes se vinculan con el campo "religioso".

En este sentido, así como advertimos que una misma re-presentación fotográfica del Gaucho Gil no resiste ser anclada sólo a una categoría (ya sea foto de prensa, documento o artificio), también el abordaje nos llevó a enfatizar la imposibilidad de pensar las fotografías analizadas atadas a nociones tales como las "religión" o "religiosidad popular" con una pretendida fijación de sentido La confirmación de este supuesto también surge de observar cómo en un escenario de heterogeneización del campo religioso argentino la interpretación de propias prácticas sociales ligadas a "lo religioso" empieza a albergar significaciones diversas y lleva a los propios estudiosos de la religión a cuestionar, re-evaluar y establecer categorías menos rígidas. 
Al respecto, hemos citado varios estudios que insisten en definir a la religión como construcción histórica y social, vinculada a una experiencia sociocultural situada; noción que desde el inicio invalida la posibilidad de establecer nominaciones fijas. En este sentido, notamos que las "rotulaciones" varían según los autores y las focalizaciones. Algunos insisten en la necesidad de dejar el término "religión" pasar a hablar de "religiosidad" como categoría más inclusiva; otros ponen el acento en la idea de la "religiosidad de los sectores populares" con la insistencia en el carácter diferencial que implica lo popular; o bien algunos prefieren hablar de "prácticas religiosas" y hasta "prácticas de sacralización", en tanto incluyen aquellas dimensiones de "lo religioso" que se articulan con los provenientes de otras esferas de la cultura.

En esta línea, atendiendo las particularidades de la festividad del Gaucho Gil y las imágenes a ella asociadas, en este trabajo retomamos algunas concepciones -propuestas por Pablo Semán, Aldo Ameigeiras, Alejandro Frigerio, María Julia Carozzi, entre otros- que nos resultaron productivas para superar la restricción del análisis del campo de la religiosidad a la relación dicotómica institucional/popular - popular/ dominante; a la vez que nos permitieron dejar de analizar las prácticas de los sectores populares como subordinadas a las imposiciones de los dominantes o como formas de "carencia" y/o modos "desviados" de la cultura hegemónica.

En ese sentido, entendemos que en el mundo del Gaucho Gil las expresiones rituales, así como las imágenes que forman parte de estas prácticas, plantean muchos matices por las cosmovisiones entrecruzadas en términos de los valores que vehiculizan, y que a nuestro parecer no admiten ser reducidos o simplificados como formas desvirtuadas del culto oficial o bien como mera oposición o resistencia a la religión católica.

En este contexto, insistimos en la necesidad de resaltar la capacidad de los sectores populares para articular de modo creativo miradas complejas en torno a lo sagrado en el marco de la devoción al Gaucho Gil. Ello tanto desde las prácticas religiosas -que incluyen rituales adscriptos a tradiciones indígenas pre-cristianas, cristianas, católicas y formas de espiritualidad de la "nueva era")- como de las prácticas extrarreligiosas -que incluyen actividades artísticas, mediáticas y/o comerciales-. Entendiendo que entre esas prácticas se imbrican diversos modos de fotografiar y re-presentar desde lo visual este mundo de lo sagrado, también consideramos relevante situar el análisis de la potencialidad creativa de los sectores sociales involucrados en un contexto de preocupaciones mayores en torno a la cultura popular y a los espectadores pasivos/consumidores activos/productores que han atravesado diversos estudios de la Comunicación/Cultura y la Cultura Visual. 
Esa visión ampliada, que tomando aportes de diversas disciplinas viene a responder el requerimiento que nos realizara Jesús Martin-Barbero de atender la multidimensionalidad de los procesos comunicativos, nos posibilitó observar la capacidad de re-elaboración activa que ejercen los sectores populares en el consumo de imágenes del Gaucho Gil. Corroboramos que a través de diversas estrategias de apropiación y re-creación, incluyendo diferentes modos de manipulación de las fotografías del corpus estudiado, los devotos y diferentes simpatizantes del "santo" popular se transforman en co-productores además de consumidores de las representaciones visuales circulantes.

Esta afirmación también nos lleva a desterrar la idea de imposición absoluta de mentalidades y representaciones que desde las teorías más apocalípticas se le atribuían a los sectores dominantes frente a los sectores marginalizados; no obstante, hay que advertir que esto no quita la necesidad de atender también a las condiciones de subalternidad a la que estas estrategias de re-creación populares están sujetas. En esta línea de análisis, también abordamos el rol activo de los fotografiados en las instancias de actos fotográficos en la festividad de Mercedes - al respecto volvemos a referirnos más adelante-.

Por otra parte, decidimos articular en nuestro análisis los aportes de Eloisa Martin, quien observando los componentes heteróclitos de la devoción/fanatismo por Gilda -la cantante de cumbia devenida en "santa" popular tras su muerte violenta en la década de 1990propone pensar "lo sagrado" más allá de "lo religioso"; es decir, plantea analizar la articulación de experiencias religiosas con elementos del mundo de la música y la cultura del espectáculo y desde allí pensarlo en términos de "prácticas de sacralización" más que de "prácticas religiosas".

Consideramos que esa perspectiva plantea intersecciones que necesitaban ser atendidas en nuestro caso de estudio. Del mismo modo en que Martin observó que muchas personas que se identificaron a sí mismas como fans de Gilda, y no precisamente como “devotos", colaboraron en el proceso de consagración de "excepcionalización" de la fallecida cantante, también nosotros observamos que sin reconocerse como "devotos", muchos sujetos se identifican en nuestro ámbito de estudio como "simpatizantes" o "seguidores" del Gaucho Gil. Desde esa posición, estas personas también colaboran en la construcción de la "fama" del Gauchito, ubicándolo en una esfera que incluso rebasa su condición de "santo" popular. Entre estos "simpatizantes" se encuentran artistas, periodistas e incluso los fotógrafos cuyas producciones aquí analizamos.

De este modo, el Gaucho Gil puede además ser considerado dentro de la lista "seres extraordinarios", junto a Eva Perón, el Che Guevara, Gardel o la misma Gilda, entre otros, a 
los que se les atribuyen "dones" y un "carisma" que los destacan "de su contexto social, étnico y estético de origen" y los vuelven disponibles, para ser apropiados. Para Martin en esas apropiaciones, que implican la acción de una contraparte humana, estos seres adquieren forma, son investidos de múltiples significados y así se completan

La conjetura posibilitó entender que las cualidades atribuidas a estos "seres" no le son intrínsecas sino que se construyen mediados por la agencia de los sujetos que le dotan de diversos sentidos e identidades, y en esos agenciamientos y las formas de simbolización de las religiosidades contemporáneas ocupan un lugar importante las re-presentaciones visuales, entre ellas las fotografías. A su vez, creemos que en ese contexto las fotos del Gaucho Gil configuran un mundo ampliado de "iconicidades móviles" (Segato, 2007) que van propiciando relaciones complejas en términos de la configuración de los rituales, la construcción de territorialidades y las identidades comunitarias.

\section{La migración de las imágenes y las nuevas formas de inscripción devocional}

En relación a los planteos anteriores, esta tesis también sirvió para reconocer la importante incidencia de las "iconicidades móviles" en la construcción predominante visual del mundo del Gaucho Gil. Estas iconicidades móviles y performáticas, entre las que se construyen las propias fotografías reproducidas a través de distintos medios, a la vez aparecen como síntoma de la emergencia de un nuevo orden territorial que marca la configuración de las religiosidades contemporáneas.

También observamos que el crecimiento de la movilidad de imágenes del Gaucho Gil y el aumento de la migración de los espectadores- consumidores-productores de dichas imágenes, desde la década de 1980 a la actualidad influyó en la transformación de los modos en que imaginamos el mundo del Gaucho Gil. En otras palabras, esas movilidades originadas por el incremento del uso de medios electrónicos, con incidencia en el consumo y la manipulación de imágenes, como por las migraciones de devotos y simpatizantes que transportan estas iconicidades, propició el pasaje de la identificación de la devoción al Gaucho Gil como una práctica de veneración rural situada en el paiubre mercedeño a su concepción como una manifestación devocional expandida, que incluso supera las fronteras geopolíticas de Corrientes.

La observación participante realizada en la festividad de Mercedes, entre 2010 y 2011, las conversaciones con quienes forman parte de la manifestación - entre ellos los propios fotógrafos-, la reflexión sobre los relatos orales, textos mediáticos diversos y la circulación 
de imágenes, dan cuenta que las formas de devoción al Gaucho Gil proliferaron en los últimos 30 años mediadas por la re-producción de iconografias en constante desplazamiento.

La breve historización desarrollada en torno a las memorias de la figura popular da cuenta que en la configuración de ese mundo visual del Gaucho Gil expandido y hasta multisituado se conjugaron diferentes formas de movilidad de creyentes, simpatizantes del "santo" popular e imágenes. Entre ellas se cuentan iconografías con una densa memoria y alta performatividad, formas teatrales propias de los acontecimientos rituales, altamente expresivos, gestuales y con un importante componente de arraigo cultural, que incidieron en su apropiación y re-producción incluso desde la práctica fotográfica. De allí surgió nuestra consideración de este mundo del Gauchito -como lo llaman los sujetos con él involucradoscomo un mundo iconográfico, fotogénico y también performático.

En primer lugar, advertimos que si bien las memorias orales que construyen al Gaucho Gil como figura rebelde y milagrosa data de mediados del siglo XIX, recién desde que la representación del "santo" popular se plasmó en una forma iconográfica hacia 1980 -a través del bulto escultórico de un gaucho sobreimpreso a una en cruz ubicado en el santuario de Mercedes- empezó a proliferar a través de reproducciones y apropiaciones diversas de dicha imagen.

Seguidamente, observamos que la proliferación de la devoción estuvo ligada a las diversas olas migratorias internas en el país, que incluyeron traslados y asentamiento de correntinos en diversas latitudes, principalmente en la provincia de Buenos Aires para conseguir trabajo. Una de ellas se da entre los años noventa y 2000 , época en que también más se visibiliza la adscripción de muchos grupos sociales con la figura del Gaucho Gil. Paralelamente a ello se dio la propagación de los "iconos-móviles" devocionales que trasladaron re-creaciones de la iconografía central del gaucho, entre otros distintivos, a modo de "heráldicas" a través de los cuerpos, las vestimentas de los fieles, accesorios, objetos varios, banderas, recuerdos.

Las iconicidades en constante movimiento marcan en el caso abordado la emergencia de aquello que Segato (2007) describe como los componentes de una religiosidad contemporánea que responden a un nuevo orden territorial; es decir, aquel donde el territorio pasa por desprenderse de los anclajes materiales fijos y adquiere movilidad.

Si bien la construcción de esos "íconos-móviles" implican una reducción de la densidad histórica-cultural de la representación por estar sometida a un proceso de simplificación que la convierte en un esquema de síntesis de fácil reproducción a través de las pantallas e incluso el marketing, también las manifestaciones devocionales visibilizan otras 
actitudes religiosas vinculadas al anclaje territorial y que hacen a su espesor histórico y cultural.

A la par de las "iconicidades móviles", la devoción al Gaucho Gil presenta inscripciones materiales iconográficas múltiples que van configurando una red de capillitas, santuarios en diversas ciudades y también a la vera de las rutas de todo el país. Estas modalidades de inscripción también están vinculadas a las actividades comerciales ambulantes de algunos creyentes, entre ellos los camioneros que fueron dejando muestra de su fe en los caminos; configurando, "un relativismo en la localidad" porque se conjuga la movilidad de las imágenes con inscripciones fijas en el paisaje que re-memoran el territorio donde el gaucho fuera degollado. Asimismo, ese territorio sagrado mercedeño no pierde centralidad referencial ya que la mayoría de los devotos acuden al santuario mayor para visitar el lugar donde se cree habita el espíritu de la divinidad.

De este modo, las formas de simbolización iconográfica de Antonio Mamerto Gil no se restringen al epicentro de la celebración central que se realiza en Mercedes, aunque este espacio no deja de ser el más importante, y también cobran relevancia las redes de altares y capillitas y las "iconicidades móviles", entre las que pueden contarse las primeras estampitas y objetos recordatorios comercializados desde la década del ochenta hasta su difusión en las pantallas de la televisión y su viralización a través de la web, entre los años noventa y 2000.

Vale señalar, que en este marco cobró relevancia especialmente hacia los años 2000 la producción, circulación y consumo de fotografias, entre ellas las producciones de los cinco fotógrafos analizados. Asimismo, los modos de difusión de estas imágenes estuvieron estrechamente relacionados a las plataformas electrónicas: páginas web, redes sociales, formatos como los e-books especialmente pensados para la red. Estos medios electrónicos no sólo aceleraron el flujo de las imágenes sino que además las volvieron disponibles para ser consumidas, manipuladas y re-creadas por diversos públicos desde la red.

En este sentido, los dispositivos digitales convirtieron a los receptores/ espectadores/ consumidores en productores. De este modo, el proceso descripto no sólo enfatiza la crisis de la concepción romántica del genio-creador en relación a las fotografías de “autor” y las múltiples prácticas de apropiación y re-semantización a las que están sometidas en la matriz intertextual de la web, sino que también abre la posibilidad de pensar las prácticas de "multicontra-visualidad" planteada Mirzoeff (2008) y a la vez dinamizar el campo de producción de representaciones hegemónicas y alternativas donde se juegan las luchas visuales por el sentido de lo sagrado. 


\section{La densa memoria y la performatividad de las fotografías}

El paisaje de iconicidades móviles articulado a las diversas formas de inscripciones materiales visuales que actuaron y actúan como vasos comunicantes y multiplicadores de las visualidades heterogéneas de/sobre el Gaucho Gil, con las que las fotografías de nuestro corpus dialogan, también llevó a este estudio a indagar en qué medida las fotos analizadas están atravesadas en sus modos constructivos por esos trayectos migración de imágenes y, por ende, condicionadas por las "contaminación" y disputas de sentidos en esos pasajes.

Dicha inquietud supuso atender en la configuración de las imágenes del "santo" popular, las estrategias de cita y apropiaciones, modos de anclaje, actualización y reactivación de iconografías desde la memoria colectiva; así como a la sobreimpresión y redefinición de esquemas y contenidos representacionales que se observan en las fotografías de interés. Para ello, apelamos a las teorías provenientes de la historia del arte, de los estudios visuales y culturales interesados en atender la memoria de las imágenes, la supervivencia de algunas formas iconográficas en los nuevos modos de imaginar la lo social desde lo visual. Asimismo, establecimos relaciones con la historicidad o el espesor temporal de las representaciones sociales y vinculaciones entre el trabajo de la representación y la performatividad en las fotografías.

Lo que observamos desde la iconografía central que representa a Antonio Gil en el bulto escultórico del santuario mercedeño, pasando por sus reproducciones en estampitas y apropiaciones fotográficas diversas, es que las imágenes del mundo iconográfico del Gauchito se construyen como un espacio de intersección de "representaciones disímiles" y, a su vez, configuran "anacronismos" porque en sus procesos constructivos intervienen formas de selección y re-codificación de elementos iconográficos provenientes de tiempos diversos.

Así por ejemplo, la iconografía central distintiva de la escultura y de las estampitas se conforman a partir de un conjunto de normas iconográficas que remiten a representaciones históricamente legitimadas en los tiempos de la colonización y la configuración de la nación moderna argentina. Tal es el caso de la cruz de devoción cristiana y la figura del gaucho; pero también aquella cruz remite al curuzú guaraní que actualiza la referencia a las prácticas rituales de veneración de los difuntos de tradición pre-cristiana; además, la figura humana que se sobreimprime a la cruz para representar a Gil tiene una fuerte reminiscencia con los rasgos de las representaciones visuales más difundidas de Jesucristo y también del Martin Fierro.

Las referencias no solo revelan el "montaje de tiempos diversos" que confluyen en esa imagen sino también manifiestan la resonancia de ciertos arquetipos identitarios que son 
elementos que le otorgan a la imagen y a la devoción del Gaucho Gil en sí un potencial performativo. En otros términos, es esa remisión a fragmentos iconográficos de rasgos hipercodificados, alojados y permanentemente actualizados en la memoria colectiva, la que produce un rápido reconocimiento en el espectador y le otorga a la re-presentación visual capacidad para incidir en la formación de valores y producción de nuevos modos de ver y dar (se) a ver.

En este sentido, observamos que la iconografia del Gaucho Gil posee una eficacia pragmática que también la convierte en una imagen potente para la cita y la apropiación. Esa potencia interpela a diferentes actores en diferentes instancias de re-producción cultural y también a los fotógrafos desde las prácticas de re-presentación fotográfica, como sucede en los casos de retratos "Devoto" y "Gaucho Gil" tomados en 2008 por Juan Pablo Faccioli y Marcos López.

Asimismo, confirmamos que la densa memoria que la imagen central del Gaucho Gil condensa, a su vez sintetiza "representaciones nodales" que propician procesos de adscripciones identitarias en torno a "lo cristiano", "lo nacional", "lo correntino", "lo guaraní”. En tanto, la práctica fotográfica apela a esas representaciones con el objetivo de actualizar, reforzar sentidos establecidos o incluso re-significarlos notoriamente, tensionado a partir de la incorporación de otros elementos los conceptos y valores que esas iconografías vehiculizan.

En este sentido, un caso ejemplificador es el abordaje realizado de la fotografía de Marcos López en la que observamos cómo el autor aprovecha la efectividad ideológicopragmática que aún pueden ejercer en la configuración de la imaginación social argentina las construcciones míticas del origen, vinculadas en este caso a la figura del gaucho argentino, para cuestionar la concepción del Gaucho Gil como un "santo" sumiso.

El fotógrafo crea una gran puesta en escena para re-inventar la estampita de esta figura popular. Le quita esos rasgos estáticos y dóciles que emparentan al "santo" popular cada vez más a la figura de los santos oficiales católicos para devolverle en este retrato la impronta de la rebeldía, del coraje, la valentía. En otras palabras, López reintroduce en el plano de la simbolización visual algunos indicadores de los pasajes de proezas de las que hablan los relatos orales más difundidos sobre Antonio Gil y que configuraron la fuerza de su imagen para encarnar la idea del "justiciero social", del "referente de lucha" de los sectores oprimidos.

En la producción del retrato Marcos López decide operar con citas y apropiaciones no sólo de la estampita, las memorias orales, la fuerza visual de ciertos colores y contrastes sino 
también de elementos de otro icono de la resistencia popular como fue Juan Moreira; aquel gaucho del texto de Eduardo Gutiérrez pero sobre todo la imagen que recreara en los setenta Leonardo Favio en una de las películas más vistas de la historia del cine argentino.

De allí, los procedimientos de cita, de re-iteración derridiana, implican repeticiones pero a su vez reinvenciones de los signos referenciados que apuntan a ponerlos en crisis, a desestabilizar las representaciones sociales cristalizadas que estos entraman. Y más del lado de la invención que de la repetición actúa el fuerte gesto teatral y pictórico que López le imprime a la obra desde la puesta en escena de la pre-producción hasta las instancias de posproducción por la que pasa la construcción del retrato. También desde las distintas instancias de mostración, como sucedió con la muestra Exceso de 2010, López juega con la conversión de lo fotográfico en pictórico, y un pasaje de la foto escultura o la foto instalación.

Es así que a través de herramientas formales y de la reflexión sobre el medio y el soporte de la imagen, los cruces, las contaminaciones de géneros pictóricos y fotográficos y la búsqueda del realce de la potencia visual de la imagen expuesta ante el espectador, esta fotografía particularmente invita a resituar la pregunta sobre factores que influyen en su performatividad. El ejemplo, nos lleva a comprender que además de los significados ideológicos diversos devenidos de tiempos precedentes que la configuración de una foto entrama, en tanto construcción social (artefacto cultural) que decididamente hacen a su performatividad, la fotografía posee además la capacidad de afectar(nos) desde su atractivo, su cualidad estética y poética, su materialidad medial.

No obstante, el análisis de la re-presentación y la performatividad no se completa hasta que se analizan los modos en que una imagen puede incidir en la concepción del mundo de los espectadores. En ese sentido, vimos que la fotografía de López, desde su aparición fue quizá una de las más reproducidas en diversos ámbitos (artísticos, periodísticos y también religiosos) y lo más interesante fue ver cómo la imagen podía reingresar al ámbito del consumo y la re-producción cultural de Mercedes, por estrategias de re-apropiación y de reinvención.

En resumen, advertimos que ciertos espectadores convertidos en productores reutilizan esa imagen para confrontar los valores naturalizados en torno al "santo", para reafirmarlos, dudar, subvertirlos, o negociar sentidos. Así, quienes se percatan de la irreverencia de López, quien resalta la rebeldía del Gaucho Gil en su creación, manipulan la imagen para quitarle vehemencia en función de lo que su sistema de creencias le admite como visible y aceptable; o bien realzar algunos de sus elementos sobre otros, en este mismo sentido. 
En definitiva, lo que el ejemplo desarrollado expone es la confirmación de parte de nuestra hipótesis inicial. Es decir, manifiesta cómo las fotografías del Gaucho Gil forman parte de complejos procesos comunicativos en los que actúan configurando diversos sentidos desde y sobre las prácticas religiosas y también extrarreligiosas.

Asimismo, esas imágenes a partir del despliegue de una serie de estrategias y en función de regímenes de (in)visibilidad e intereses de quienes las manipulan, una vez puestas a circular en instancias y espacios discursivos diversos construyen representaciones hegemónicas y/o alternativas de la religiosidad correntina. Sin embargo, aquí podemos agregar en términos de lo ya indicado por Caggiano (2012), que en esos repertorios alternativos también se van infiltrando modos hegemónicos de mirar, siendo esto lo que en parte no le permite a algunos espectadores-productores en los que ha calado fuertemente la educación religiosa católica aceptar y/o re-crear un "santo" beligerante como el de López; o no admiten que en la propia escena del retrato de 2008 resuenen aún elementos "otros" que hacen al fenómeno del Gaucho Gil además de la dialéctica gaucho obediente/gaucho rebelde que forma parte central de las matrices de sentido de la leyenda.

Esto sucede porque las imágenes y su retórica de liberación no son libres a pesar de su capacidad de "escapar" a los anclajes de la palabra y las localizaciones geográficas de origen, desafiar las clasificaciones y la fijación de significaciones, cobrando nueva vida y nuevos sentidos, muchas veces inimaginables para sus creadores, a través del tiempo. Las fotografias están insertas y condicionadas por el juego de las resistencias, los conflictos, las negociaciones, las seducciones, las complicidades propias del proceso hegemónico.

\section{La reconfiguración de representaciones y la dimensión política de la mirada}

Los procesos complejos que atraviesan la conformación de las imágenes exigieron a este análisis ir más allá del abordaje sincrónico del corpus de las fotografías de los cinco fotógrafos elegidos, sin desatenderlo claro. De allí, se buscó un encuadre más panorámico, por decirlo en términos de planos fotográficos, para ver aquello que rodea al punto central de focalización y a los fines de atender los tiempos heterogéneos que las imágenes condensan, las formas, modos de desplazamiento y redefiniciones, así como los antecedentes representacionales en relación a los cuales los conjuntos visuales contemporáneos adquieren valor y poder para incidir en los modos de percepción, imaginación y acción de los sujetos que las miran. 
La inquietud por incorporar la diacronía en el abordaje, que implicó la historización de la configuración del mundo iconográfico del Gaucho Gil, partiendo de las imágenes vinculadas a la devoción desde el propio santuario mercedeño, también puso énfasis en el contraste de las imágenes actuales del corpus con fotos históricas de la religiosidad correntina con el objetivo de analizar las recurrencias y rupturas y las reconfiguraciones en las modalidades de construcción de la mirada.

La estrategia de abordaje también surge de entender que cada imagen se inserta en un campo discursivo específico, comporta antecedentes en relación a los cuáles se sitúa y construye una visión del mundo, de los cuales puede o no tomar elementos y reorganizarlos con la adhesión de información y relaciones nuevas. En síntesis, como plantea Caggiano, en su propuesta de análisis contrastivo, la emergencia de un "repertorio visual alternativo" sólo puede ser comprendido en contraste a aquellos repertorios que los anteceden y a los que se opone; e inversamente, un "repertorio oficial" sólo puede ser desnaturalizado o desmitificado leyéndolo en relación con las imágenes nuevas que lo desafían.

En este sentido, analizamos fotos históricas producidas durante el siglo XX en relación a los modos y ámbitos de construcción de las miradas y memorias característicos de la formación discursiva en la que se insertan. En ese marco, como primera instancia, el abordaje focalizó en fotos de prácticas religiosas correntinas capturadas entre 1900 y 1969 que presentan los álbumes del Centenario argentino conservados en el Museo Histórico de Corrientes y algunas cajas de imágenes halladas en el Archivo General de la Nación (AGN). Lo que allí se observó es que sobre todos las imágenes de la primera mitad del siglo XX (1900-1930) construyeron representaciones hegemónicas de la religiosidad correntina y aparecen muy emparentadas a vistas urbanas que construyeron la idea del "progreso" del trazado, la edificación y la industria en la ciudad de Corrientes; así como a los retratos de la familias ilustres, personajes de la política y autoridades eclesiásticas.

En ese paisaje de repertorios visuales, que podemos afirmar se construyeron como instrumentos para legitimar procesos y personajes que sostenían el orden social conservador y anti popular dominante de aquella época, las prácticas y rituales de los sectores populares no católicos son invisibilizados y hasta considerados "indignos" de darse a ver por algunos referentes académicos como citamos en este trabajo.

Asimismo, la indagación pone de manifiesto que la mayoría de las imágenes relevadas restringe la referencia a los cultos católicos de relevancia para institución eclesiástica: las misas, festividades y peregrinaciones en honor a la Virgen de la Merced, patrona de la ciudad de Corrientes; la Cruz de los Milagros, que recuerda el "milagro" 
fundacional de la ciudad de Corrientes y la Virgen de Itatí, patrona de la provincia de Corrientes.

En cuanto a los modos de construcción de la mirada que se adoptaron para mostrar/ocultar esas prácticas de la religiosidad correntina, podemos concluir que estos repertorios "oficiales" se basaron en esquemas de representación donde predomina una composición estática y de planos generales -también influenciada por la tecnología fotográfica vigente- que privilegia la visibilización de la multitud de las procesiones y misas; mientras que en los pocos planos medios encontrados se pone de relieve el posicionamiento de los santos o las autoridades de la iglesia, en estrecha vinculación a determinados actores que ocupan un rol representativo dentro de los esquemas de poder del orden social legitimado.

Esas modalidades de representación tendientes perennizar una "historia oficial" consecuente con memorias e identidades pretendidamente unitarias fueron configurando un régimen visual dominante. Ese régimen incluso modela hasta la actualidad algunas formas de re-presentar las prácticas religiosas católicas y populares no católicas correntinas, como la propia festividad del Gaucho Gil. Esto sobre todo se observa en aquellas imágenes difundidas por los medios tradicionales de comunicación masiva. Allí, esas modalidades dar a ver y ocultar también actúan en consecuencia con criterios de noticiabilidad e intereses editoriales, comerciales, que realzan la multitud y visibilizan determinados personajes y ocultan otros.

Frente a la configuración de esa mirada disciplinaria e institucional normalizadora propia de los sistemas de representación dominados por una élite social y política conservadora del siglo XX, indagamos si ese régimen dominante sufrió algún trastocamiento o transformación que posibilitara alguna reconfiguración representacional fotográfica de la religiosidad correntina. Efectivamente, observamos que hacia los años 1980 y 1990, en un contexto diferente al de inicios del siglo XX -signado en este caso entre otros procesos por el retorno de la democracia al país, la expansión de la cultura mediática y la diversificación religiosa- fue posible advertir la reactivación de algunos repertorios de "lo popular". Con ello se produce también un cambio de los modos de mirar y valorar las prácticas religiosas correntinas y en ese proceso de reconfiguración tuvo mucho que ver la visibilización expandida de la devoción del Gaucho Gil.

De este modo, observamos cómo sin dejar de circular y reproducirse el esquema representacional de la mirada institucional y normalizadora, se sobreimprime en las propuestas fotográficas del Gaucho Gil un segundo régimen de visión predominante que tiene que ver con una estética melodramática y barroca. 
También advertimos que la forma melodramática-barroca de mostrar los rituales plantea algunas paradojas en las fotografías analizadas. Por un lado, esta modalidad de construir imágenes configura un régimen y una estética que permite visibilizar la diversidad religiosa, los dramas, las pasiones, lo festivo, los relieves, los espesores, el desborde propio de las manifestaciones de los márgenes del orden racional y disciplinado; a su vez expone la vivencia de los sujetos y prácticas antes ocultados, como así también permite realzar el carácter diferencial de la religiosidad popular contemporánea, en la que enmarcamos el caso de Gil.

Por otro lado, se observa que algunas imágenes melodramáticas ejecutan operaciones de reducción de la densidad de ese mundo melodramático y barroco a un recetario de fórmulas visuales de alto impacto y representaciones estereotipadas que resultan serviles al consumo ligero del mercado massmediático y abonan la cultura de la conmoción.

$\mathrm{Al}$ respecto, también destacamos algunas consideraciones de los teóricos latinoamericanos de la comunicación que resaltan las potencialidades del melodrama no sólo como un tipo de estética que se vale de la exaltación de lo sentimental y lo patético en sus formas con el fin de conmover al espectador y con ello cubrir algunas expectativas de consumo del mercado, sino como un modo de narrar y de sentir más abarcativo. Jesús Martin-Barbero y Hermann Herlinghaus hablan del melodrama como una modalidad narrativa que echa raíz en una matriz cultural de larga data de fuerte ligazón con la tradición popular y que atraviesa el imaginario moderno tiñendo con una predominancia de lo subjetivo a la mayoría de los discursos de la cultura contemporánea.

En este marco, la fotografía melodramática del Gaucho Gil analizada, como discurso afectado, también parecería albergar la capacidad de mediar entre los imaginarios, las manifestaciones y demandas de los sectores populares como de los sectores dominantes, articulada a los formatos y lógicas industriales de producción y consumo de la cultura de masas; estas capturas de sentimiento se plantean como una mediación entre la cultura popular y masiva.

Más allá de las diversas interpretaciones, la heterogeneidad de miradas yuxtapuestas que exponen en términos generales las producciones del Gaucho Gil abordadas habla de la coexistencia -aunque sea desigual- de diferentes regímenes escópicos funcionando en los modos de visualizar "lo religioso", la religiosidad popular correntina y/o las prácticas de sacralización ligadas a este "santo" de los milagros. Hablamos de un régimen ligado a la construcción de la mirada eclesiástica, institucional, normalizadora que sigue modelando los modos de ver y dar(se) a ver y también del régimen barroco-melodramático que se 
manifiesta con fuerza atravesando los modos visualización del mundo del Gaucho Gil y también de otras manifestaciones religiosas en las que aquí no nos detenemos.

Además, las diferentes producciones de los fotógrafos y sus búsquedas de sentidos diferenciales confirman que los regímenes de visibilidad, como plantea Reguillo (2008) comportan "franjas de indeterminación transformadoras" atravesadas por acciones sociales y escenarios histórico-sociales y culturales cambiantes donde las miradas logran descentrarse; es decir, desmarcarse de un esquema dominante para inaugurar modos "otros" de mirar.

En esta línea, observamos que las búsquedas personales de los fotógrafos desde las producciones abordadas, la insistencia en construir miradas más implicadas y reflexivas sobre aquello que retratan y con lo que interactúan, abonan esas prácticas de descentramientos de las miradas e inauguran algunos intentos de re-distribución de lo sensible - en términos de Rancière (2010)- donde la mirada configura con fuerza su dimensión política.

Así, vemos cómo algunas tomas de Juan Pablo Faccioli y Guillermo Rusconi intentan apartarse del estereotipo para visibilizar los bordes de la festividad, el mestizaje, la densidad de la atmósfera socio-cultural, las condiciones de vida y las prácticas identitarias de los participantes en el escenario de la festividad del Gaucho Gil.

Por su parte, el trabajo de Eduardo Longoni realza la lógica diferencial de las prácticas de religiosidad popular que visibiliza festividad del Gauchito Gil en relación a los cultos católicos. Y lo hace a partir de la enfatización del rasgo "infernal" de la fiesta -como él mismo la denomina-, así como la potencia visual, la expresión e inscripción de la fe en los cuerpos. Sus imágenes expresan en primer plano la expresividad de los cuerpos, la vestimenta, el exceso de rojo saturado, de velas, de ofrendas, de calor y sudor, de amontonamiento, el desenfreno de comida y bebida como modos de relaciones con lo sagrado que están "más allá" de los modelos dogmáticos.

En tanto, la propuesta de Estela Izuel, focaliza la mirada en las diversas capas semánticas de la festividad a partir de un zoom en los exvotos, objetos y superficies que configuran la simbología del santuario del Gaucho Gil. Le interesan las inscripciones superpuestas devenidas de tiempos diversos que esconde cada rincón de mundo iconográfico del "santo" popular, y así aquello que pasaría desapercibido a la vista distraída de cualquier transeúnte-espectador, aparece en las fotografías indagatorias de Izuel como "palimpsestos de la memoria" punzantes, interpeladores, al modo de los efectos que suelen tener los macros en la fotografía. 
Mientras, Marcos López en su serie Sub-realismo criollo y en particular en el retrato de 2008 al que referimos ya ampliamente plantea una apropiación de la figura de Antonio Gil $y$, en una suerte de operación desmitificadora bartheana, colabora en la mostración del artificio, de la recreación del sentido común cristalizada en la iconografía de la estampita más difundida del "santo" popular, dando con ello lugar a otras formas de mirar y pensar dicha imagen.

\section{masivo \\ 6. La imagen-acto, la imagen-identidad y las articulaciones de lo popular-}

Desde el inicio de esta investigación señalamos la existencia de una diversidad de aportes reflexivos en el campo de las ciencias sociales sobre los diferentes aspectos que hacen de la producción y la re-producción fotográfica. Particularmente, en esta tesis resaltamos la importancia de redoblar los esfuerzos para repensar las estrategias de puesta en discurso que la foto entrama y entender cómo cada re-presentación fotográfica adquiere en sus diversas instancias de mostración cierto "poder" para incidir en las formas de concepción y valoración del mundo de los que la miran.

En este sentido, comprendimos que además de analizar la dimensión representacional de la imagen material visual era necesario prestar atención a las diversas instancias que atraviesan la construcción de las miradas. En ese marco, nos aproximamos al acto fotográfico porque en el trabajo de campo realizado en Mercedes observamos cómo las prácticas de fotografiar, posar, mostrarse, construirse una imagen de sí para el otro frente a la cámara, formaban una parte activa y primordial de la festividad del Gaucho Gil; así como de su configuración como un mundo predominante visual.

De este modo, en esta indagación nos valimos de la potencialidad de la lectura performancial para reflexionar sobre algunas capturas fotográficas en relación a notas de observación de prácticas de fotografiar y también conversaciones con los fotógrafos. Específicamente, seguimos las trayectorias fotográficas de Juan Pablo Faccioli y Guillermo Rusconi en la festividad del Gaucho Gil en Mercedes y los elegimos porque los autores vienen desarrollando búsquedas continuas y compartidas en la práctica de fotografiar al Gauchito. También fue esto que los llevó a ejercitar en cada acercamiento al escenario devocional-festivo transformaciones en las maneras de mirar y mostrar lo que allí sucede.

Lo indagado da cuenta que en principio el objetivo del trabajo de estos fotógrafos era 
responder al aumento de demanda de imágenes que la multitudinaria manifestación religiosa popular generó desde distintos medios de comunicación masiva. En este sentido, iban en búsqueda de la captura de la multitud y otros tipos de recortes requeridos por las empresas periodísticas. Pero luego, la experiencia del acto de fotografiar provocó en ellos la necesidad de pasar de alguna manera a ser parte de esa fiesta con el fin de dar a ver desde adentro y desde una mirada más cercana e implicada los fragmentos de ese complejo universo, por lo que los viajes al epicentro del festejo se hicieron más frecuentes y con estadías menos acotadas.

Así, surgen las fotos de corta distancia y que se construyen bajo un concepto que en muchas ocasiones, no en todas, responden a intereses compartidos entre fotógrafos y fotografiados. Asimismo, en el trabajo de campo y el seguimiento de algunos actos fotográficos se hizo más clara la configuración de estas prácticas como un espacio de articulaciones dialógicas, de intersecciones, seducciones, confluencia de pactos entre fotógrafos y fotografiados.

De allí, definimos a los actos fotográficos como un lugar donde conviven las ansias y los intereses de poseer el objeto que el fotógrafo se apresta a dar a ver y donde éste que se precipita como poseedor, algunas veces el productor se topa con que está siendo poseído, interpelado por ese objeto que de pronto irrumpe en la escena en su carácter de sujeto activo, demandando participación en el proceso de construcción de la imagen. El análisis comprobó que quienes se perciben observados por la cámara, posan y pre-modelizan su imagen fotográfica -como también decía Barthes (1989)- y con ello adoptan, negocian posiciones para dar(se) a ver y también disputan proyecciones identitarias diversas. Allí la noción de imagen-acto se relaciona con la de imagen-identidad y refiere al "uso simbólico" que la gente hace en esta instancia para construir una imagen de sí para mostrarla al otro.

Lo observado nos llevó a cuestionar la idea de distancia "objetiva" que se planteó históricamente entre fotógrafo y fotografiado como uno de los atributos más valorados del registro fotográfico, también la consideración del fotografiado como mero objeto fácilmente cosificable y la idea de pasividad o alienación que adoptan los sujetos retratados ante la cámara. Claramente, en un escenario como el de la festividad del Gaucho Gil todos los presupuestos anteriores se echan por tierra porque allí los participantes del festejo en su mayoría no rehúyen de las cámaras sino todo lo contrario, vivencian su devoción con y para cámaras, montan puestas teatrales y con ello maneras de mostrarse que también van delimitando las posiciones de quienes los miran y fotografían en esa escena.

En este sentido, lo explorado nos posibilitó confirmar cómo los retratados pueden 
asumir, en determinadas instancias, el rol de co-productores de las imágenes; ello sin desatender que están condicionados por relaciones posicionales y de poder que el dispositivo del acto fotográfico articula y donde el fotografiado se plantea en una desigualdad de posición ante el fotógrafo que es quien finalmente delimita el recorte y elige qué mostrar y qué ocultar.

Por otra parte, sin dejar de considerar que tanto las experiencias y prácticas de los sectores populares y las representaciones fotográficas -concebidas como producciones masivas-configuran dimensiones diferentes, esta reflexión hizo hincapié en la necesaria vinculación de estas dimensiones. El estudio de caso muestra de qué modo la fotografía, como dispositivo creado para llegar a las masas, también sirve para re-producir y re-crear visualmente memorias e imaginarios configuradores de adscripciones identitarias siempre sometidas a una permanente negociación con las experiencias y los códigos de percepción de los sectores populares.

En esta línea, el trabajo siguió de cerca los planteos de Martin-Barbero, Aníbal Ford y Eduardo Romano, entre otros, porque desde allí se considera que la mirada puesta en estos cruces e intersecciones es la que permite pensar a los sectores populares fotografiados como co-productores de las imágenes que circulan sobre ellos en los medios masivos. También observamos que es en esas instancias de encuentros, de negociaciones con los fotógrafos, y otras condicionantes socio-históricas, situacionales y regímenes de visibilidad/invisibilidad, que los retratados son capaces de desarrollar tácticas - como planteaba De Certeau - para producir marcas y dejar sus huellas en las propuestas de los fotógrafos.

Finalmente, para cerrar estas conclusiones y en virtud de los abordajes específicos realizados quisiéramos resaltar la importancia de seguir explorando la fotografía en relación a la imagen-acto, aquella que se construye inscripta en una situación referencial determinada y con un efecto pragmático; y en este sentido alentamos a apostar a la mirada performancial poco desarrollada en el ámbito de la Comunicación/Cultura a los fines de abrir otros caminos en la indagación de los modos de codificación, en este caso del hecho fotográfico como producción cultural.

Entendemos que la fotografia indagada desde el acto que la configura se ofrece como uno de los lugares más prolificos para pensar la problemática las afiliaciones y proyecciones identitarias como formas de posicionamiento y articulación en el plano de lo popular no comprensibles como desligadas de lo masivo. Ya que, como se observa en el caso de las imágenes del Gaucho Gil, si bien la foto como dispositivo moderno se adapta y responde a las lógicas de producción y difusión masiva negando desde esa matriz a lo popular, a su vez se 
define por el cruce de experiencias concretas de fotógrafos y los sectores populares fotografiados, constituyéndose como espacio de existencia y visibilización de lo popular. Es decir, en la medida en que la imagen fotográfica producida para las masas, como algunas fotos de prensa aquí analizadas, posee la capacidad de ocluir, exotizar o banalizar la mirada sobre el devoto o participante de la festividad y sus prácticas, negando las diferencias y homogeneizando las afiliaciones identitarias, también posee la aptitud para develar, dar cuenta y exponer la heterogeneidad constitutiva de dichas prácticas.

Desde esta posición que complejiza la lectura de la imagen fotográfica y en función de nuestra hipótesis inicial, afirmamos que las fotografías del Gaucho Gil analizadas no sólo vehiculan significaciones existentes, sino que las re-crean, las re-significan y así participan de la configuración del mundo iconográfico del "santo” popular.

De modo más amplio, a través de su valoración en diversas instancias de producción, circulación y consumo, estas imágenes también colaboran en la reconfiguración de las representaciones de la religiosidad correntina, adscribiéndose a nuevos regímenes visuales que interpelan nuestros modos de dar a ver las prácticas religiosas, y también cumplen un rol activo en la dinámica de fijación y des-estabilización de memorias e identidades en torno a las prácticas de sacralización. 


\section{REFERENCIAS BIBLIOGRÁFICAS}

ABU-LUGHOD, Lila (2006) “La interpretación de las culturas después de la televisión”, en ICONOS N²4, pp. 119-141

AGAMBEN, Giorgio (2011) “¿Qué es un dispositivo?”, en Sociológica. Año 26, No 73, pp. 249- 264.

ALABARCES, Pablo (2001) Fútbol y Patria: Deporte, narrativas nacionales e identidades en la Argentina, 1920-1998, Tesis doctoral, University of Brighton, Diciembre.

ALABARCES, Pablo y RODRIGUEZ, María Graciela (1997) "Futbol y Patria: la crisis de la representación de lo nacional en el futbol argentino", en North American Society of Sociology of Sport (NASSS) Conference, Toronto, Canada, 5 al 8 de Noviembre. Disponible en: http://www.efdeportes.com/efd10/pamr10.htm

ALABARCES, Pablo; AÑON, Valeria; CONDE, Mariana (2008) "Un destino sudamericano. La invención de los estudios sobre cultura popular en la Argentina”, en Alabarces, Pablo y María G. Rodríguez (comps.): Resistencias y mediaciones. Estudios sobre cultura popular. Buenos Aires: Paidós.

ALTHUSSER, Louis. (1988) Ideología y aparatos ideológicos de Estado. Buenos Aires: Nueva Visión.

ALVARADO, Margarita, MEGE, Pedro y BÁEZ, Christian (ed.) (2001) Mapuche: Fotografía del Siglo XIX. Construcción y Montaje de un Imaginario, Santiago: Editorial Pewen.

ALVARADO, Margarita y GIORDANO, Mariana (2007) "Imágenes de indígenas con pasaporte abierto: del Gran Chaco a la Tierra del Fuego", en Revista Magallania. Instituto del Hombre Austral, Universidad de Magallanes, Vol.35, № 2, Punta Arenas, Chile, pp. 15-36.

ADORNO, Theodor y HORKHEIMER, Max (1969) Dialéctica del Iluminismo. Buenos Aires: Sur.

AMEIGEIRAS, Aldo (2008) La religiosidad popular: creencias religiosas en la sociedad argentina. Buenos Aires: Ed. Biblioteca Nacional. (2014) Símbolos, rituales e identidades nacionales. Buenos Aires: CLACSO.

ANGENOT, Marc (2005) "Fin de los grandes relatos, privatización de la utopía y retórica del resentimiento", en Estudios. $\mathrm{N}^{\mathrm{o}} 17$, p. 21-34. 
APPADURAI, Arjun (2001). La modernidad desbordada. Dimensiones culturales de la globalización. Buenos Aires: Trilce/FCE.

ARANCIBIA, Víctor (2007) "El espesor temporal de las imágenes cinematográficas. A propósito de La guerra gaucha: Representaciones sociales y condiciones de producción", en Actas de las Jornadas Interescuelas y Departamentos de Historia, Tucumán: UNT.

ARFUCH, Leonor (2002) El espacio biográfico. Cap. 1 Buenos Aires: Fondo de Cultura Económica.

ARISTARCO, Guido (1968) Historia de las teorías cinematográficas. Barcelona: Lumen.

ASSUNÇÃO, Fernando (2007) Historia del gaucho. El gaucho: ser y quehacer. Buenos Aires: Claridad.

AUMONT, Jaques (1992) La imagen. Barcelona: Paidós.

BARRIOS, Cleopatra (2011) “Una aproximación a las representaciones visuales de prácticas religiosas en la provincia de Corrientes", en Revista Afuera. Estudios de Crítica Cultural. $\quad \mathrm{N}^{\mathrm{o}} \quad 10, \quad$ Buenos Aires, Disponible en: http://www.revistaafuera.com/articulo.php?id=182\&nro $=10$ (2013) "El Gauchito Gil neo expresionista del cine digital argentino", en Revista La Trama de la Comunicación, UNR, Rosario, Vol 17, pp 293 -311. Disponible en: http://www.latrama.fcpolit.unr.edu.ar/index.php/trama/article/view/431 (2013) “Actuar, fotografiar, per-formar identidades en y desde prácticas de religiosidad popular en la provincia de Corrientes", en Giordano, M; Sudar, L; Isler, R (edits) Memoria e imaginario del Nordeste Argentino. Rosario: Prohistoria. pp. 89119.

(2014) "Capturas de sentimiento de la cultura popular-masiva. Fotoperiodismo y religiosidad en clave dialógica-melodramática”, en Revista Tram(p)as de la Comunicación y la Cultura, FPyCS Universidad Nacional de la Plata, $\mathrm{N}^{\circ}$ 76, pp. 49-60. Disponible en: http://www.revistatrampas.com.ar/2014/05/capturas-de-sentimiento-de-la-cultura.html

BARRIOS, Cleopatra y GIORDANO, Mariana (2015) "De la criminalidad a la santificación. Sentidos inestables de la fotografía de Isidro Velázquez (Argentina)”, en Fotocinema, $\mathrm{N}^{\circ} 10$, España. $\quad$ pp. 353-382. Disponible: URL:http://www.revistafotocinema.com/index.php?journal=fotocinema\&page=issue\& op $=\% 20$ view \&path[] $=25$

BARTHES, Roland (1989) La cámara lúcida. Barcelona: Paidós. 
(2004) "El efecto de lo real”, en AA.VV Realismo. ¿Mito, doctrina o tendencia histórica?. Buenos Aires: Quadrata.

BACZKO, Bronisław (1984) Les imaginaires sociaux. Mémoire et espoirs collectifs. París: Payot.

BAEZA, Pepe (2001) Por una función crítica de la fotografía de prensa. Barcelona: Editorial Gustavo Gili.

BAUMAN, Zygmunt (1994) Pensando sociológicamente. Buenos Aires: Nueva Visión.

BELTING, Hans (2007) Antropología de la imagen. Buenos Aires: Katz Editores.

BERGER, John (2000) Modos de ver. Barcelona: Gustavo Gili.

BERNÁRDEZ, Manuel (1900) De Buenos Aires a Iguazú. Crónicas de un viaje periodístico a Corrientes y Misiones. Buenos Aires: Imprenta de La Nación.

BOURDIEU, Pierre (1979) La distinción. Criterio y bases sociales del gusto. Madrid: Taurus. (1979) Un arte intermedio. México: Nueva Imagen.

(2004) El baile de los solteros. La crisis de la sociedad campesina en el Bearne.

Barcelona: Editorial Anagrama.

BAJTIN, Mijail (1982) "El problema de los géneros discursivos" en La estética de la creación verbal. México: Siglo XXI.

(1989), "El problema del contenido, el materia y la forma en la creación literaria", en Teoría y estética de la novela. Madrid: Taurus. pp. 13-75.

(1990) La cultura popular en la edad media y el renacimiento. Madrid: Alianza.

BATCHEN, Geoffrey (2004) Arder en deseos. La concepción de la fotografía. Barcelona: Gustavo Gili.

BENJAMIN, Walter (1989). "La obra de arte en la época de su reproductibilidad técnica”, en Discursos Interrumpidos I. Buenos Aires: Taurus.

BHABHA, Hommi (2000) "Narrando la nación”, en Fernández Bravo, Álvaro (comp) La invención de la Nación. Lecturas de la identidad de Herder a Homi Bhabha. Buenos aires: Manantial, pp. 211-219. (2002). El lugar de la cultura. Buenos Aires: Manantial.

BONDAR, I. (2011) Escenas (re)memorativas. (Re)memoración de los niños difuntos (angelitos)Táva Villa Olivari. Provincia de Corrientes. Argentina. Tesis Maestría en Semiótica Discursiva. FHyCS. UNAM. Posadas. Inédito. (2013) "Escenas (re)memorativas: lecturas deconstructivas sobre la (re)memoración de los niños difuntos. Villa Olivari. Corrientes. Argentina”, en Bondar, I (comp). 
Ñande Mandu'a Mokoi. Sobre muerte, morir, ritos y fiestas. Editorial Universitaria. UNaM. Posadas, pp. 29-58.

BELTING, Hans (2007) Antropología de la imagen. Buenos Aires: Katz Editores.

BRANDES, Stanley. 2005. "Retratos en acción: la España de Cristina García Rodero", en AAVV. Maneras de Mirar. Madrid: Consejo Superior de Investigaciones Científicas

BREDEKAMP, Horst (2010) Theorie des Bildakts. Berlín: Suhrkamp Verlag.

BRODSKY, Marcelo y PANTOJA, Julio (ed) (2009) Políticas del cuerpo en la fotografía latinoamericana. Buenos Aires: La Marca.

BURKE, Peter (2005). Visto y no visto. El uso de la imagen como documento histórico. Barcelona: Ed. Crítica.

BURUCÚA, José Emilio (2006) Historia y Ambivalencia. Ensayos sobre arte. Buenos Aires: Biblos.

BUTLER, Judith (2002) Cuerpos que importan. Sobre los límites materiales y discursivos del "sexo”. Buenos Aires: Paidós. (2001) El género en disputa: el feminismo y la subversión de la identidad. México, D.F.: Paidós.

BUXO I REY, María. (1998) "Mirarse y agenciarse. Espacios estéticos de la performance fotográfica", en Revista de Dialectología y Tradiciones Populares, Tomo LIII, Madrid, pp. 175-190.

CAGGIANO, Sergio (2011) "El ordenamiento y la diseminación. Imágenes y categorías en el archivo general de la nación”, en Giordano, Mariana y Reyero, Alejandra (Comps). Identidades en foco. Fotografía e investigación social. Resistencia: Facultad de Artes, Diseño y Ciencias de la Cultura UNNE e Instituto de Investigaciones Geohistóricas CONICET/UNNE. pp. 255-284.

(2012). El sentido común visual. Disputas en torno a género, "raza” y clase en imágenes de circulación pública. Buenos Aires: Ed. Miño Dávila.

CALABRESE, Omar (1994) La era neo-barroca. Buenos Aires: Cátedra.

CAMBLONG, Ana María (2014) "Semiótica de fronteras: dimensiones y pasiones territoriales", en Conferencia en el I Foro Fronteras Culturales. Disponible en: http://www.artes.unne.edu.ar

CANGI, Adrián (2011) "Poética de la luz, política del gesto", en Revista Nomadías, № 14, pp. 157-169. Disponible en: http://www.revistas.uchile.cl/ 
CASCO, Fredi (2013) "La belleza de las (otras) fiestas. Fotografías de Fernando Allen". Entrevista a Ticio Escobar, en Sueño de la Razón, N³. Disponible: http://www.suenodelarazon.org/03-festa.html

CASTELLOTE, Alejandro (2010) "Perdonen el resentimiento", en Marcos López. Buenos Aires: Ediciones Lariviere. S.A.

CAROZZI, María Julia (2006) “Antiguos difuntos y difuntos nuevos. Las canonizaciones populares en la década del 90”, en Miguens, D. Semán, P. (edits) Entre cumbias, santos y piquetes. Buenos Aires: Biblos.

CAROZZI, María Julia y Cernadas, César (ed) (2007) Ciencias sociales y religión en América Latina. Perspectivas en debate. Buenos Aires: Ed. Biblos.

CEBRELLI, Alejandra y ARANCIBIA, Víctor (2005) Representaciones sociales. Modos de mirar y de hacer. Salta: CEPIHA-CIUNSa.

(2007) "Sobre el espesor temporal de las representaciones sociales en el discurso periodístico. Los aborígenes en la prensa local: 2006-2007 y 1859”, en Actas de las XII Jornadas Interescuelas de Historia, Tucumán: UNT.

(2008) "Las tram(p)as de las representaciones. Apuntes para el análisis de las coberturas mediáticas de problemáticas referidas a pueblos originarios”. En Actas de XII Jornadas Nacionales de Investigadores en Comunicación, Disponible en http://www.redcomunicacion.org/memorias

(2012) Luchas y transformaciones sociales en Salta. Salta: Agencia de Ciencia y Técnica y CEPIHA.

COLÓN, Eliseo (2000) "Neotelevisión y melodrama. Las narrativas testimoniales", en Herlinghaus, Hermann (ed) Narraciones anacrónicas de la modernidad. Santiago de Chile, Cuarto Propio, pp. 140-156.

COLUCCIO, Félix (1986) Cultos y canonizaciones populares de Argentina. Buenos Aires: Ediciones del Sol.

CONCHA LAGOS, Pablo (2004) Más allá del referente, fotografia. Del índex a la palabra. Santiago de Chile: Pontificia Universidad Católica de Chile.

CORTES ROCA, Paola (2011) El tiempo de la máquina. La Plata: Colihue.

CUARTEROLO, Miguel (2000) Soldados de la Memoria. Imágenes y Hombres de la Guerra Del Paraguay. Buenos Aires: Planeta

CHARTIER, Roger (1992) El Mundo como Representación. Historia Cultural: entre práctica y representación. Barcelona: Editorial Gedisa. 
CHUMBITA, Hugo (1995) "Bandoleros santificados", en Todo es Historia, $\mathrm{N}^{\circ} 340$. Disponible en: http://www.hugochumbita.com.ar

DEBORD, Guy. (1995). La sociedad del espectáculo. Buenos Aires: Biblioteca de la Mirada. DE CERTEAU, Michel (2000). La invención de lo cotidiano I. Artes de hacer. México: Universidad Iberoamericana.

DELEUZE, Gilles (1991) Foucault. Barcelona: Paidós.

(1993) "Precepto, afecto y concepto", en ¿Qué es la filosofia? Buenos Aires: Anagrama.

DEL BOCA, Mario (2009) Textos sobre fotografía. Córdoba: Ed. del Boulevard.

DELGADO, Nora (2007) Discursividades de un género patético. Tesis de Doctorado UNC. Córdoba.

DERRIDA, Jaques (1998) "Firma, acontecimiento, contexto", en DERRIDA, Jaques, Márgenes de la filosofía, Cátedra, Madrid, pp. 347-372. Edición digital de Derrida en castellano disponible en: http://www.jacquesderrida.com.ar.

DÍAZ, Claudio (2006) "Las disputas por la apropiación del gaucho la emergencia del "folklore" en la cultura de masas", en Actas de JALLA, Bogotá.

DIDI-HUBERMAN, Georges (2006) Ante el tiempo. Historia y anacronismo de las imágenes. Buenos Aires: Ariana Hidalgo. (2009) La imagen superviviente. Historia del Arte y tiempo de los fantasmas según Aby Warburg. Madrid: Abada.

DRI, Rubén (coord.) (2003) Símbolos y fetiches religiosos en la construcción de la identidad popular. Buenos Aires: Biblos,

DUBOIS, Phillippe (2008) El acto fotográfico y otros ensayos. Buenos Aires: La Marca. (2011) "Cinéma et art contemporain: vers un cinémad'exposition? De la migration d'un dispositif". Manuscrito, París. Université Sorbonne Nouvelle Paris 3. EDWARDS, Elizabeth (ed.) (1992) Anthropology \& Photography 1860-1920. London: New Haven and London.

EVANS, Jessica y HALL, Stuart (eds.) (1999) Visual Culture: the reader, London: SAGE.

FOGELMAN, Patricia (comp) (2010) Religiosidad, cultura y poder. Temas y problemas de la historiografía reciente. Buenos Aires: Lumiere.

FONTCUBERTA, Joan (ed.) (2010) La cámara de Pandora.La fotografi@ después de la fotografía. Barcelona: Gustavo Gili.

FORD, Aníbal (1985) "Cultura dominante y cultura popular", en Ford, A., Rivera, J.B. y Romano, E.. Medios de comunicación y cultura popular. Buenos Aires: Legasa. 
FORNI, F. (1986) "Reflexión sociológica sobre el tema de la religiosidad popular", en Sociedad y Religión $\mathrm{N}^{\mathrm{o}}$ 3, pp. 4-24.

FOUCAULT, Michel (1989) Vigilar y Castigar. Nacimiento de la prisión. Buenos Aires: Siglo XXI.

(1991) La Arqueología del Saber. Siglo XXI: México.

FREUND, Giselle (1993). La fotografía como documento social. Barcelona: Gustavo Gili.

FRIGERIO, Alejandro (1995) "Secularización y nuevos movimientos religiosos”, en Boletín de Lecturas Sociales y Económicas, UCA- FCSE, Año 2, Nº 7.

(2007) "Repensando el monopolio del catolicismo en la Argentina", en Ciencias Sociales y religión en América Latina. Perspectivas en debate, Carozzi, M y Cernadas, C (coords), Editorial Biblos, Buenos Aires, pp. 87-113.

(2011) "La gente siempre creyó en algo diferente a lo que la Iglesia intentaba imponer”, entrevista en Revista Nuestra Cultura, Año 3, n¹4, pp. 5-6.

(2015) "Tres santuarios del Gauchito Gil en el conurbano (3)", en Diversa Blog. Disponible en: http://www.diversidadreligiosa.com.ar/blog

GARCÍA, Marcelino (2000) “El texto escolar: complejo mnemo-semiótico matricial”, en Estudios Regionales, Año 9, No 14, 23-29. Posadas: Secretaría de Investigación y Posgrado, FHyCS-UNaM. (2004) Narración. Semiosis/Memoria. Posadas: Editorial Universitaria - UNaM.

GARCIA VARAS, Ana (2011) Filosofia de la imagen. Salamanca: Universidad de Salamanca.

GINZGURG, Carlo (1991) El queso y los gusanos. El cosmos, según un molinero del siglo XVI. Barcelona: Muchnik (2008) “Indicios. Raíces de un paradigma de inferencias indiciales", en Mitos, emblemas, indicios. Morfología e historia. Barcelona: Gedisa.

GIORDANO, Mariana (2004) Discurso e imagen sobre el indígena chaqueño. La Plata, Al Margen.

(2003) "De jesuitas a franciscanos. Imaginario de la labor misional entre los indígenas chaqueños”, en Revista Complutense de Historia de América, nº 29, pp. 5-24. (2004) "Itinerario de imágenes del indígena chaqueño. Del Territorio Indio del Norte al Territorio Nacional y Provincia del Chaco", en Anuario de Estudios Americanos, Tomo LXI, $n^{\circ} 2$, pp. 517-550. 
(2014) "Viajes y expediciones en el Gran Chaco. Construcciones visuales de una etnocartografía del siglo XX”, en Alvarado, Margarita y Bajas, María Paz (eds.).

Dentro y fuera del cuadro. Identidad, representación y autorepresentación visual de los pueblos indígenas de América Latina (Siglo XIX-XXI). Santiago de Chile: ICIIS Pehuén Editores, en prensa.

GIORDANO, Mariana e ISLER, Ronald (2009) "Mapeo de colecciones fotográficas de Corrientes. Catastrar para investigar", en Actas del $4^{\circ}$ Encuentro Internacional y $7^{\circ}$ Nacional de Recuperación y Conservación de la Memoria Visual. Berazategui: Municipalidad de Berazategui.

GIORDANO, Mariana y MÉNDEZ, Patricia (2003) "Justificando un proyecto: textos y fotografías de los frailes de Propaganda Fide sobre los indios chaqueños”, en Actas del IX Congreso Internacional de Teoría e Historia de las Artes, Buenos Aires: Centro Argentino de Investigadores en Arte - CAIA.

GIORDANO, Mariana; BARRIOS, Cleopatra; PAGEAU, Christian y GÓMEZ MONTERO, Camilo (2014) Cine de gauchos milagrosos correntinos. Perspectivas en debate. Resistencia: IIGHI.

GRIGNON, Claude y PASSERON, Jean Claude (1989) Lo culto y lo popular: miserabilismo y populismo en la Sociología y en la Literatura. Buenos Aires: Nueva Visión.

GREEN, David (ed.) (2007) ¿Qué ha sido de la fotografía? Barcelona: Gustavo Gili.

GRIMSON, Alejandro (1997) "Relatos de la diferencia y la igualdad. Los bolivianos en Buenos Aires", en Nueva Sociedad, Comunicación culturas e identidades en el fin de siglo, $\mathrm{N}^{\circ} 147$, pp. 96-107.

(2004) La cultura en las crisis latinoamericanas. Buenos Aires: CLACSO. (2007) Cultura y Neoliberalismo. Buenos Aires: CLACSO.

GRIMSON, Alejandro y VARELA, Mirta (1999) "Recepción, culturas populares y política. Desplazamientos del campo de comunicación y cultura en la Argentina", en Audiencias, cultura y poder. Estudios sobre televisión. Buenos Aires: Eudeba.

GROSSBERG, Lawrence (2009) "El Corazón de los estudios culturales: contextualidad, construccionismo y complejidad”, en Tabula Rasa, N¹0, Bogotá, pp. 13-48.

GRÜNER, Eduardo (2001) El sitio de la mirada. Buenos Aires: Norma. (2002) "El sitio de la mirada", en Conferencia dictada en SEMA. Disponible en: http://www.sema.org.ar/downloads/SemPrim_02_Gruner.pdf

GONZÁLEZ, Valeria (2010) “Debut y despedida. Fotografías de Marcos López, 1978-2009”, en Marcos López. Buenos Aires: Ediciones Lariviere. S.A. 
GUASCH, Ana María (2003) “Los estudios visuales. Un estado de la cuestión”, en Estudios

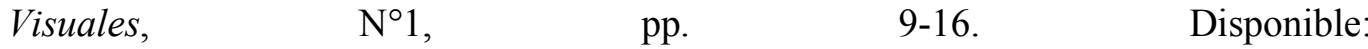
http://www.estudiosvisuales.net/revista/pdf/num1/guasch.pdf

GUBER, R (2012) La etnografía, método, campo y reflexividad. Buenos Aires: Siglo XXI.

GUIDO, Raquel (2006) “Cuerpo: soporte y productor de múltiples imágenes”, en Matoso, Elina (comp). El cuerpo in-cierto. Arte, cultura, sociedad. Buenos Aires: Letra Viva, Universidad de Buenos Aires.

GUTIÉRREZ, Ramón; GUTIÉRREZ VIÑUALES y Rodrigo; VIÑUALES, Graciela María (1997) Pintura, escultura y fotografía en Iberoamérica, siglos XIX y XX. Madrid: Lunwerg Editores.

HALL, Stuart (1980) "Codificar/Decodificar", en Culture, media y Lenguaje, London, Hutchinson, pp. 129-139. (2010) Sin garantías. Trayectorias y problemáticas en estudios culturales. Restrepo, E; Walsh, C. y Vich, V (edit) Popayán: Envión Editores.

(2003) “Introducción: ¿Quién necesita identidad?”, en Stuart Hall, Paul Du Gay (coords) Cuestiones de identidad cultural.. Madrid: Amorrortu, pp. 13-39.

HERLINGHUS, Hermann (ed) (2002) Narraciones anacrónicas de la modernidad. Santiago de Chile: Cuarto Propio.

HUYSSEN, Andreas (2002) En busca del futuro perdido. México: Fondo de Cultura Económica.

IMBERT, Gérard (1999) "La hipervisibilidad televisiva: nuevos imaginarios/nuevos rituales comunicativos", en I Jornadas de Televisión. Madrid: Universidad Juan Carlos I.

JAY, Martin (1988) "Regímenes escópicos de la modernidad" en Vision and visuality 2, Hal Foster Ed. Seattle Bay Press, (en Vacchieri, Ariana, 1992, El medio es la TV).

KAY, Ronald (1980) Del espacio de acá. Señales para una mirada americana. Santiago de Chile: Ed. Asociados.

KOSSOY, Boris (2001) Fotografía e Historia. Buenos Aires: La Marca.

KRAUTSTOFL, Elena (2014) "Territorio de fronteras y espacio de cuerpo/mujer. Peregrinación transnacional de las paseras entre Posadas (Argentina) y Encarnación (Paraguay)", en La Rivada, N³, diciembre. Disponible en: http://www.larivada.com.ar

LACLAU, Ernesto y MOUFFE, Chantal (2004) Hegemonía y estrategia socialista. Hacia una radicalización de la democracia. Buenos Aires: FCE. 
LE BRETON, David (1999) Las pasiones ordinarias, Cap. 2: Cuerpo y comunicación.

Buenos Aires: Nueva Visión.

LEMAGNY, Jean Claude (2008) La sombra y el tiempo. La fotografía como arte. Buenos Aires: La Marca.

LIDA, Miranda (2013) "La "nación católica" y la historia argentina contemporánea", en Corpus 3, no 2. http://corpusarchivos.revues.org/579.

LOJO, María Rosa. (2007) Cuerpos resplandecientes. Santos populares argentinos. Buenos Aires: Sudamericana.

LONGONI, Eduardo y PICCINI, Jorge (2013). Superficies. Libro digital, disponible en: http://www.eduardolongoni.com.ar.

LOTMAN, Iuri (1996). La semiosfera I. Madrid: Cátedra (1993) "El símbolo en el sistema de la cultura". Escritos, Revista del Centro de Ciencias del Lenguaje, $\mathrm{N}^{\circ}$ 9, pp. 47-60.

LUDMER, Josefina (1994) El género gauchesco. Un tratado sobre la patria. Buenos Aires: Perfil libros

LUMBRERAS, María (2010) "Magia, acción y materia. La imagen de la Bildwissenschaft", en Anuario del Departamento de Historia y Teoría del Arte º22, pp. 241-262. Disponible en: http://dialnet.unirioja.es/servlet/articulo? codigo=3360208.

MALLIMACI, Fortunato y GIMÉNEZ- BÉLIVEAU, Verónica. (2007) “Creencias e increencia en el Cono Sur de América. Entre la religiosidad difusa, la pluralización del campo religioso y las relaciones con lo público y lo político”, en Revista Argentina de Sociología, Año 5, No 9, pp. 44-63.

MALOSETTI COSTA, Laura. (2001) Los primeros modernos. Arte y sociedad en Buenos Aires a fines del siglo XIX. Buenos Aires: Fondo de Cultura Económica. (2002). "Presentar/representar. Tensiones en la activación de los poderes de una imagen", en Revista de crítica Literaria Latinoamericana. Año XXVIII, № 56. Lima - Hannover, pp.93-109.

"El poder de las imágenes". Disponible en: http://www.eldiariodeljuicio.com.ar/?q=content/el-poder-de-las-im\%C3\%A1geneslaura-malosetti-costa

MANOVICH, LEV (2001) El lenguaje de los nuevos medios de comunicación. La imagen de la era digital. Buenos Aires: Paidós.

MARIN, Louis (2009) "Poder, representación, imagen”, en Prismas. Revista de historia intelectual, $\mathrm{N}^{\mathrm{o}} 13$, pp. 135-153. 
MÁRMORA, Lelio (1997) "Los inmigrantes de países vecinos”, en Discriminación y racismo en América Latina. Ed. Ignacio Klich, Mario Rapoport. Buenos Aires: Grupo Editor Nuevo Hacer, pp. 33-36

MARTÍN, Eloísa (2002) “Entre el legado y la inculturación: dinámicas de la correntinización de la devoción a la Virgen de Itatí”, en Ciudad Virtual de Antropología y Arqueología. Disponible en http://www.naya.org.ar/congreso2002 (2007) “Aportes al concepto de religiosidad popular", en Carozzi, M y Cernadas, C (ed) Ciencias sociales y religión en América Latina. Perspectivas en debate. Ed. Biblos, Buenos Aires. (2008) “Seres extraordinarios, más allá de la devoción y los fans”, en Todavía, № 20, Disponible: http://www.revistatodavia.com.ar/todavia27/20.sociedadestxt.html.

MARTÍN-BARBERO, Jesús (1984) “Comunicación desde la cultura: Perder el objeto para ganar el proceso" en Revista Signo y Pensamiento, N 5. Universidad Javeriana, Facultad de Comunicación, Bogotá, pp. 17-24.

(1988) "Matrices culturales de la telenovela", en Estudios sobre las Culturas Contemporáneas, vol. II, núm. 5, Universidad de Colima, México. pp. 137-164. (1989) Procesos de Comunicación y Matrices de Cultura. Itinerario para salir de la razón dualista. México: FELAFACS GG- Ediciones G. Gili. (1992) Televisión y melodrama. Géneros y lecturas de la televisión en Colombia. Bogotá: Tercer Mundo.

(1996) “Comunicación: el descentramiento de la modernidad”, en Análisi, N 19, pp. 79-94.

(1998) De los medios a las mediaciones. Comunicación, cultura y hegemonía. Bogotá: Convenio Andrés Bello.

(1999) “Aventuras de un cartógrafo mestizo en el campo de la comunicación”, en Revista Latina de Comunicación Social, $\mathrm{N}^{\circ} 19$, Disponible en: http://www.ull.es/publicaciones/latina/a1999fj1/64jmb.htm (2002) Oficio de cartógrafo. Travesías latinoamericanas de la comunicación en la cultura. Santiago de Chile: FCE.

MASOTTA, Carlos (2004) "Representación e iconografía de dos tipos nacionales. El caso de las postales etnográficas en la Argentina 1900-1930”, en Penhos, Marta et al. Arte y antropología en Argentina. Buenos Aires: Fundación Espigas/Telefónica, pp. 67-105. 
MATTELART, Armand y SCHMUCLER, Héctor (2012) Conversatorio "Presente y pasado del campo de la comunicación", en XIV Congreso de Red de Carreras de Comunicación: Investigación y extensión en Comunicación, UNQ.

MCPHAIL FANGER, Elsie (2011) "La imagen como objeto interdisciplinario", en Razón y Palabra, № 77, agosto-octubre. Disponible: http://www.razonypalabra.org.mx

MIGUEL, Estefanía (2013) Marcos López y la década del noventa: radiografía fotográfica del neoliberalismo criollo. Tesis Licenciatura en Comunicación Social. Universidad Nacional de Rosario. Inédito.

MIDDLETON, D. Y EDWARDS, D. (1992) (comp.) Memoria compartida. La naturaleza social del recuerdo y el olvido. Barcelona: Paidós.

MUDROVCIC, María Inés (2005) Historia, narración y memoria. Madrid: Akal.

MITCHELL, W. J. T. (2003) "Mostrando el ver: una crítica de la cultura visual”, en Estudios $\begin{array}{llll}\text { Visuales } & I & \text { pp. } & \text { 19-40. }\end{array}$ http://www.estudiosvisuales.net/revista/pdf/num1/mitchell.pdf

MIRZOEFF, Nicholas (2003) Una introducción a la cultura visual. Barcelona: Paidós.

MOXEY, Keith (2009) "Los estudios visuales y el giro icónico", en Estudios Visuales, № 6, pp. 8-27. Disponible en: http://www.estudiosvisuales.net/revista/pdf/num6/moxey_EV6.pdf

MUKAROVSKY, Jan (1977) "El arte como hecho semiológico", en Escritos de Estética y Semiótica del Arte. Barcelona: Gustavo Gili.

NARANJO JUAN (ed.) (2006) Fotografía, antropología y colonialismo (1845-2006). Barcelona: Gustavo Gili.

OLIVERA, Guillermo (1996) "Mirada, rostro y reproductibilidad técnica: la aporía de la televisión" en Estudios, № 6, Córdoba, pp. 83-91.

ORTIZ, Renato (2004). Taquigrafiando lo social. La subjetividad en la era de la fluidez. Buenos Aires: Siglo XXI.

OTT, Michaela (2002) "El discurso de lo melodramático. Entre el cristianismo, psicoanálisis y cine”, en Herlinghaus, Hermann (ed) Narraciones anacrónicas de la modernidad. Cuarto Propio, Santiago de Chile, pp. 254-260.

PALMA, Federico (1959) La fotografía en Corrientes. Corrientes: Escuela Taller de Artes Gráficas de la Provincia.

PANOFSKY, Erwin (1983) El significado de las artes visuales, Madrid: Alianza.

PAPALINI, Vanina (2011) “Conjugar las emociones: del 'yo' al 'nosotros”, en Versión N ${ }^{\circ}$ 26, Julio. Universidad Autónoma Metropolitana Unidad Xochimilco, México D.F. 
PARKER, Cristian (2014). "Pluralismo religioso y cambio de paradigma identitario en el campo político latinoamericano actual”, en Símbolos, rituales e identidades nacionales, compilado por Ameigeiras, Aldo, 171-195. Buenos Aires: CLACSO.

PEIRCE, Charles (1987) Obra lógico-semiótica (Trad. Ramón Alcalde y M. Prelooker) Madrid: Taurus.

PENHOS, Marta (2005) Ver, conocer, dominar. Imágenes de Sudamérica a fines del siglo

XVIII. Buenos Aires: Siglo XXI.

PEREZ, David (ed) (2004) La certeza vulnerable. Cuerpo y fotografía en el siglo XXI. , Barcelona: Editorial Gustavo Gili

PIÑEIRO, Enrique. (2005) "El eje sacro-profano: mesianismo y rebeldía de los gauchillos alzados correntinos", en Amarilla, R. (comp). Bandoleros rurales correntinos. La Plata: Ediciones A1 Margen, pp. 69-78.

POOLE, Déborah (2000) Visión, raza y modernidad. Una economía visual del mundo andino de imágenes. Lima Sur: Casa de Estudios del Socialismo y Consejería en Proyectos.

PRIAMO, Luis y DJENDEREDJIAN, Julio (2007) Ciudad y campo entre dos siglos. Buenos Aires, Cuyo y el Litoral en 1890-1910. Fotografias de Samuel Rimathé. Buenos Aires: Ediciones Fundación Antorchas.

PRIETO, Adolfo (1988) El discurso criollista en la Argentina en la formación de la Argentina moderna. Buenos Aires: Sudamericana.

QUIÑONEZ, María Gabriela (2013) "De la ciudad colonial a la ciudad moderna. Un recorrido por la fotografía urbana de Corrientes (1875-1914), en Giordano, Mariana; Sudar, Luciana \& Isler, Ronald (edits) Memoria e imaginario en el Nordeste argentino. Rosario: Prohistoria.

RANCIÈRE, Jacques (2010) El espectador emancipado. Buenos Aires: Bordes Manantial.

REGUILLO, Rossana. (2007) "Formas del saber. Narrativas y poderes diferenciales en el paisaje neoliberal", en Grimson, Alejandro (edit) Cultura y Neoliberalism. Buenos Aires: CLACSO pp. 91-110. (2008) "Políticas de la (In) visibilidad. La construcción social de la diferencia", en Diploma superior en Educación, Imágenes y Medios. Buenos Aires: CLACSO, mimeo.

REYERO, Alejandra (2008) "Entre el reconocimiento, la impugnación y la negación visual. La ausencia del indígena chaqueño en la fotografía de Pedro Luis Raota”, en Actas del XXVIII Encuentro De Geohistoria Regional. Instituto de Investigaciones Geohistóricas - CONICET, Resistencia, pp. 680-686. 
(2014) La construcción de la imagen del otro como creación de disenso. Usos y sentidos de la fotografía etnográfica chaqueña en tiempos de estetización de la experiencia. Tesis de Doctorado en Artes. Universidad Nacional de Córdoba. Inédito.

RICHARD, Nelly (2007) Fracturas en la memoria. Arte y pensamiento crítico. Buenos Aires: Siglo XXI. (edit) (2010) En torno a los Estudios Culturales. Localidades, trayectorias y disputas. Buenos Aires: CLACSO.

RIVERA, Jorge (1980). El folletín. Buenos Aires: C.E. de A. L.

RIVERA CUSICANQUI, Silvia (2010) Ch'ixinakax utxiwa: una reflexión sobre prácticas y discursos descolonizadores. Buenos Aires: Retazos-Tinta Limón.

RODRÍGUEZ, María Graciela (2010) "Mi pie izquierdo", en Oficios Terrestres, 26, UNLP, FPyCS, La Plata. pp. 93-104.

ROLNIK, Suely (2010) "Furor de archivo", en Revista electrónica Estudios Visuales N. 7 , pp.115- 129

ROMANO, Eduardo (1973) “Apuntes sobre cultura popular y peronismo", en AA.VV.: La cultura popular del peronismo. Buenos Aires: Cimarrón.

ROMERO, Luis (1999) “Una Nación católica: 1880-1946”, en La Argentina en el siglo XX, editado por Carlos Altamirano, 314-324.Buenos Aires: Ariel.

SAID, Edward (2004) El mundo, el texto, el crítico. Barcelona: Debate.

SALAS, Andrés (2008) Gauchito Gil. De devoción local a mito nacional. Buenos Aires: Editorial Dunken

SAN JUAN SUAREZ, Claudio (2010). La santidad popular de los bandidos rurales. El culto al Gaucho Gil. Tesis Maestría del Programa de Posgrado en Estudios Latinoamericanos. México: UNAM.

SÁNCHEZ CARRETERO, Cristina (2005) "Desde Madrid con amor. La performance como hilo conductor de narrativas. En AAVV. Maneras de Mirar. Madrid: Consejo Superior de Investigaciones Científicas.

SÁNCHEZ MONTALBAN, Francisco (2004) "El dios fotogénico. El festejo religioso a través de la imagen fotográfica”, en Zainac N²6, pp. 669-687. (2006). “Fotografía, muerte y religiosidad”, en Zainak No. 28, págs. 331-349

SAINTOUT, Florencia (2003) Abrir la comunicación. Tradición y movimiento en el campo académico. La Plata, Universidad Nacional de La Plata.

(2008) "Los estudios socioculturales y la comunicación: un mapa desplazado", en Revista Latinoamericana de Ciencias de la Comunicación. pp 144-153. 
SAIDÓN, Gabriela (2011) Santos ruteros. De la Difunta Correa al Gaucho Gil. Tusquets Editores, Buenos Aires.

SARLO, Beatriz (2000) El imperio de los sentimientos. Buenos Aires: Editorial Norma.

SEMÁN, Pablo (2001) "Cosmológica, holista, y relacional: una corriente de la religiosidad popular contemporánea”, en Ciencias Sociales y Religión/ Ciências Sociais e Religião, Porto Alegre, año 3, n. 3, p. 45-74. (2006) Bajo continuo, Gorla, Buenos Aires. (2009) “Culturas populares: Lo imprescindible de la desfamiliarización”, Maguaré, 23,pp. 181-205. (2010) "Diferencia y transversalidad en la religiosidad de los sectores populares: mirando con telescopio luego de haber usado el microscopio", en Apuntes de Investigación, $\mathrm{N}^{\circ} 18$, pp. 79-107.

(2013) "Pluralismo religioso en una sociedad de pluralidad jerarquizada", en Corpus [En línea], Vol 3, № 2. Disponible en: http://corpusarchivos.revues.org/584

SEGATO, Rita (2007) La Nación y sus otros. Raza, etnicidad y diversidad religiosa en tiempos de Políticas de la Identidad. Buenos Aires: Prometeo. (2008), "La faccionalización de la República y el paisaje religioso como índice de una nueva territorialidad" en Aurelio Alonso (comp.): América Latina y el Caribe: territorios religiosos y desafios para el diálogo, Buenos Aires, Clacso, p. 42.

SOLÍS CARNICER, María del Mar (2004) La construcción de un liderazgo político en la provincia de Corrientes. Juan Ramón Vidal (1883- 1940). Tesis de Maestría en Ciencias Políticas. UNNE. Inédito.

SONTAG, Susan (2003) Ante el dolor de los demás. Barcelona: Santillana.

SORLIN, Pierre (2004) El "siglo" de la imagen analógica. Los hijos de Nadar. Buenos Aires: La Marca.

SOULAGES, François (2005) Estética de la fotografía. Buenos Aires: La Marca.

SCHAEFFER, Jean Marie (1990) La imagen precaria. Del dispositivo fotográfico. Madrid:

Cátedra. (2012) Arte, objetos, ficción, cuerpo. Cuatro ensayos sobre estética. Buenos Aires: Biblos.

SCHMUCLER, Héctor (1984) "Un proyecto de comunicación/cultura", en Revista de Comunicación/Cultura, $\mathrm{N}^{\circ} 12$, México: Ed. Galerna.

STRELCZENIA, Marisa (2004) "Fotografía y memoria: La escena ausente", en Ojos Crueles, temas de fotografía y sociedad $\mathrm{N}^{\mathrm{o}} 1$, Buenos Aires, pp.76-80. 
TAGG, John (2005) El peso de la representación. Ensayos sobre fotografias e historias. Barcelona: Gustavo Gili.

TAYLOR, Diana (2012) Performance. Buenos Aires: Asunto Impresiones Ediciones.

TERRERO, Patricia (1983) El radioteatro Buenos Aires: C.E. de A.L.

THOMPSON, Edward Palmer (1995) Costumbres en común. Barcelona: Crítica.

TURNER, Víctor (1988) El proceso ritual. Estructura y antiestructura. Madrid: Taurus.

VALLE, María Celeste (2011) “'El marginal me llaman': Resistencias subalternas en torno a una literatura marginal", en Actas del Cuarto Congreso Internacional CELEHIS de Literatura, Mar del Plata, 7, 8 y 9 de noviembre. Disponible en: http://www.mdp.edu.ar/humanidades/letras/celehis/congreso/2011/actas/ponencias/val le.htm

VIOTTI, Nicolás (2011) "Notas sobre socialidad y jerarquización en la nueva religiosidad de los sectores medios urbanos", en Papeles de Trabajo, Año 5, № 8, noviembre, pp. $135-152$.

WIEVIORKA, Annette (1998) L'ère du témoin. Paris: Plon.

WILLIAMS, Raymond (1980) Marxismo y literatura. Barcelona: Península. 
Conversaciones con Juan Pablo Faccioli y Guillermo Rusconi

Reflexiones vinculadas a la investigación científica y periodística aseguran que el rol de los medios masivos fue crucial en la difusión y expansión de los fenómenos de religiosidad popular argentinos en las últimas décadas. En este marco, los fotógrafos y audiovisulistas ocuparon un papel fundamental en otorgarle visibilidad a las prácticas y discursos que la configuran. Entre ellos, antes de iniciar mi indagación y preparar esta entrevista, me interesaba contactarme con fotógrafos que presentaran una producción diferencial en torno $a$ mirar y dar a ver la festividad del Gaucho Gil en la provincia de Corrientes.

De este modo llego a Guillermo Rusconi y Juan Pablo Faccioli, dos jóvenes fotoreporteros que iniciaron alrededor de 2004 y sostienen hasta la actualidad ensayos fotográficos sobre la manifestación devocional de nuestro interés.

Creo que lo trascendente de sus trabajos reside justamente en esa producción sostenida y además en el hecho que las imágenes obtenidas en los últimos años, se construyó como una "búsqueda compartida" tanto desde la logística como la construcción conceptual. Los fotógrafos también trabajaron de este modo en coberturas fotoperiodísticas en las peregrinaciones a la Basílica de Itatí, por ello en el relato van entramando experiencias que hacen a lo realizado tanto en Mercedes como en Itatí. Lo curioso en el contraste, es que ambos, hablan de su predilección por fotografiar en el Gauchito, porque aseguran es más "fotogénico" entre otras características.

Para saber más sobre esta experiencia me reuní con los autores en dos ocasiones. Un primer encuentro con ambos se dio en un café de la ciudad Capital correntina el 30 de julio de 2012. Allí miramos algunas fotografías desde una notebook y charlamos sobre los recorridos conjuntos. Luego vinieron las entrevistas individuales también mediadas por imágenes. La primera realizada el 12 de junio de 2013 en una sala de la redacción de diario Época con Faccioli, y la segunda en un café de Capital Federal con Rusconi el 5 de julio de 2013.

Corrientes, 30/07/2012

\section{CB: ¿Cómo surge la elección de fotografiar prácticas religiosas?}

JPF: No sé si se podría hablar de elección. El tema surge de la necesidad de responder a las demandas de los medios para los cuales trabajamos. Además en un diario de tirada provincial como en el que trabajo y en una provincia como Corrientes, la cobertura de las festividades religiosas forma parte de la agenda obligada de los medios. 
GR: Sí yo creo que en una primera instancia no elegimos, el tema te llega. Después sí. Al menos a mí, creo que a ambos, nos pasó especialmente con el Gauchito (Gil).

JPF: Es cierto. El Gauchito tuvo algo particular para nosotros. Por eso, después de un primer acercamiento al que llegamos por una demanda diarios y agencias en mi caso, porque hice trabajos para Época y Crónica y también $D y N$ y Telam y Guille Cultura (Subsecretaría) y $L a$ República; decidimos volver por nuestra cuenta para trabajos más personales.

CB: ¿Qué tiene la festividad del Gaucho Gil que los hizo volver para trabajos personales que no tiene Itatí u otras festividades?

GR: Mirá, el primer trabajo que hago en el Gauchito es para el documental que estrenó hace poco Lía Dansker (Antonio Gil). Fuimos con gente de la Subsecretaría de Cultura donde trabajé hasta que entré al diario La República en 2006. Eso fue 2004 y no fuimos sólo el día de la fiesta, el 8 de enero, grabamos testimonios en la previa y días posteriores, recorrimos varios escenarios de Mercedes que son claves para la leyenda. Y si bien no adhiero a ninguna creencia, desde que llegamos, el antes, el durante y el después, presentó un clima, una mística particular. Estar en el Gauchito es muy fuerte primero a nivel personal por la mística particular que sobrevuela en el aire los días de la fiesta y también a nivel imagen.

CB: Las imágenes son impactantes ¿Hay una expresividad propia de la fiesta y de la gente más allá de los objetivos de captura que ustedes persiguen que condicionan la construcción de la imagen?

GR: Creo que el Gauchito es fotogénico.

JPF: Sí, es una buena definición.

GR: Y es fuerte a nivel imagen por la simbología; velas, banderas, estatuillas, tatuajes por todos lados; en torno a los ritos y en los cuerpos. Hay expresividad en la gente; tenés hasta los que van lookeados especialmente para la ocasión, por ejemplo vestidos como el Gaucho Gil, y por el otro te encontrás con una marea roja inundando todos los espacios.

CB: ¿Esa gente lookeada nos habla de una predisposición de los participantes y devotos a ser fotografiados? ¿Cómo se da la relación entre ustedes y los fotografiados en ese momento de la captura?

GR: Sí hay predisposición de buena parte de los participantes. Vos vas y la gente te ve con la cámara y ya te cuenta su historia y se muestran orgullosos de ser fotografiados, algo que no sucede por ahí con otras festividades.

CB: ¿Ni en Itatí? ¿Por qué creen que sucede esto?

JPF: De algún modo en Itatí sucede pero no tanto. Tenés personajes... Recuerdo a doña Asunta (Penesky) ella va siempre con un velo y túnica y es muy fotografiada siempre por el parecido con las vírgenes o las santas. También otra pareja que bordan sus bombacha, chaleco y toda ropa especialmente preparada para la festividad, entre otros que te buscan o de alguna manera llaman tu atención para que los fotografíes en alguna pose o por ejemplo una foto de retrato. Eso como modo de testimonio de que estuvieron allí, con la Virgen que te piden que se las mandes. Pero hay otra gente que no busca o que no le interesa, que vive de forma más íntima su devoción si es posible alejada de las cámaras.

CB: ¿Se encontraron con alguien que les haya negado o pedido que no les saquen fotos? JPF: No, no porque uno sondea antes, observa. Al menos nosotros dos creo compartimos esto de no robar una imagen que no esté implícita o explícitamente aprobada. Y además en este tiempo y en estas fiestas tan masivas donde hay medios, cámaras y celulares incluso 
particulares dando vueltas, están acostumbrados a ser fotografiados y filmados. Pero la cosa va por otro lado. En el Gaucho creo que casi todos están más predispuestos.

\section{CB: ¿Tal vez sea un sobre-exposición sumado a la predisposición?}

GR: Sí podría ser, no sé. Creo que lo que diferencia es que en Itatí hay todavía un componente de solemnidad que hace que la gente sea un poco más recatada, algo muy relacionado con los cultos católicos, institucionalizados. Lo que prácticamente desaparece en el Gauchito porque es más informal, muy festivo y extremadamente expresivo. Tenés gente bailando, tocando chamamé por un lado, a pocos metros la carne asándose en las parrillas y familias enteras compartiendo la comida y la música que pasa por la radio y a la noche del 8 de enero todos celebrando con fuegos artificiales.

\section{CB: ¿Y es esa informalidad también los atrae para sus producciones?}

GR: Sí, a nivel imagen son todos los componentes, informalidad, expresividad gestual, corporal, etc. Pero además, a nivel personal, festividades como Itatí nunca me generaron emoción. En el Gaucho Gil, como en otra cobertura que hice en la producción de una película sobre el Gaucho Lega, otro gaucho rebelde de Saladas Corrientes más contemporáneo que Gil, sucedieron algunas cosas intensas difíciles de explicar porque son poco racionales.

CB: Quiero preguntar sobre algunas imágenes en particular pero antes me contarían ¿cómo surge esta especie de búsquedas compartidas?

JPF: Nos conocemos de las coberturas en la ciudad y el interior. Construimos una amistad y compartimos intereses con la fotografía. Esto pasa con otros colegas pero nosotros coincidimos en cursos y talleres que tomamos y que brindamos en la universidad. Colaboramos en producciones varias incluso de publicidad y también con algunas historias que se nos presentaron para hacer fotografías para los diarios.

GR: Es una relación de amistad y de respeto profesional también, de confianza y de compartir miradas.

CB: ¿Cómo es eso de compartir miradas y cómo se conecta esto con las coberturas en Itatí y Mercedes?

GR: Claro porque hay formas de trabajar, cuestiones técnicas no desligadas de lo conceptual a la hora de hacer fotos que es necesario compartir cuando se hacen trabajos en equipo. Pero lo de Itatí y Mercedes fueron viajes donde compartimos cuestiones de logística y una idea inicial pero después ya en el lugar mantuvimos independencia de criterios para hacer imágenes.

\section{CB: ¿Qué idea por ejemplo?}

JPF: Eso tiene que ver con diferentes objetivos y condiciones de trabajo. En Itatí recuerdo que compartimos al menos dos viajes, 2006 y 2008. Yo fui solo desde ahí hasta 2012 inclusive porque me pidieron fotos desde las agencias y Crónica. Al Gaucho fuimos más veces juntos desde 2006 a 2012. Y si miramos un poco estas producciones en Mercedes vemos que primero íbamos con cámara directa retratando escenas donde el protagonista era el rito en torno al Gaucho Gil y la cantidad, el amontonamiento de gente (Va pasando las imágenes de carpeta a carpeta mientras explica). Pero para los últimos años el fin era buscar más el dramatismo y darle el protagonismo al peregrino. Era una búsqueda más de lo individual que de lo colectivo. Y como consigna acordamos con Guille empezar a marcar las cosas con la luz, la luz ambiente, no usar luz artificial y probar algunas reglas de composición.

CB: Se podría decir que existen al menos dos etapas marcadas en la producción de la festividad del Gaucho Gil, una más relacionada con la captura de la multitud, lo 
colectivo y otra más relacionada con los sujetos con una carga emotiva en primeros planos...

GR: En Itatí pasó lo mismo, solo que por ahí, yo particularmente fui menos.

CB: ¿Podríamos hablar más detenidamente sobre esto después con más tiempo? Pero antes de irnos ipodríamos hablar un poco sobre las condiciones de producción, las particulares facilidades o dificultades para ese tratamiento de la luz y para realizar determinadas composiciones en dos festividades como estas que son tan multitudinarias? GR: Siempre es complicado componer fotos en lugares o en acontecimientos donde hay amontonamiento de gente y más aún si esa multitud es tan dinámica como las peregrinaciones de Itatí o la marea de gente que viene y va en el Gaucho Gil. Pero frente a eso el hecho de ir varias veces, conocer el terreno, los ritos, los momentos y los personajes es una ventaja. Además hay como una maduración en la mirada. Volver te hace mirar de otro modo.

JPF: Coincido. Uno va conociendo las condiciones de trabajo de las coberturas anteriores y sabe que es difícil por el amontonamiento. Pararte y componer una foto era prácticamente pedir mucho, te pisan, el espacio es muy reducido, más aún en el Gauchito que en Itatí. Pero la experiencia hace que uno vaya ganando lugar donde uno estima que puede aparecer la foto. Y manejar las condiciones de luz siempre es un desafío. Ves acá tenemos dos imágenes similares una de él y otra mía, en el momento cuando la virgen es trasladada tras la peregrinación náutica (muestra dos fotos de la festividad de Itatí de julio de 2008). A veces trabajamos para la luz como en esa foto de Rusconi y otras para la sombra como en este caso en la mía. Es difícil lograr una medición exacta en esa posición en que la gente se amontona, te empuja, esa imagen se te va porque el tiempo y lo que sucede corre y te encandilan los rayos de sol que amenazan quemarte la foto o por el contrario cuando la sombra podría dejarla a oscuras.

CB: Se hizo tarde, pero nos debemos otro encuentro ¿les parece? (Luego de casi dos horas de charla, acordamos otras cuestiones, doy las gracias por el tiempo dispensado y cortamos la conversación)

Corrientes, 12/06/2013

CB: Quiero retomar el tema de las composiciones y el tratamiento de la luz. En la charla de café el año pasado veíamos a lo último algunas fotos de Itatí y estuve revisando algunas fotos muy impactantes del Gauchito de 2008 sobre las que anoté unas consultas. Fijate ésta. Le pusiste $L u z$ en tu mirada y forma parte de la muestra itinerante y me dijiste en otra oportunidad que es una de tus preferidas ¿por qué?

JPF: Porque creo que está bastante lograda. Era un día que estaba lloviendo. Había una luz plana. Si bien no era luz de sol directa que me reflejaba con fuerza, era una luz tenue, suave que me ayudó en la fotografía y me permitió que no se queme esta parte que está el Gauchito (me muestra con la mano derecha en la lateral derecha de la foto donde se representa la imagen del santo popular que es saludada por unas manos que se extienden en forma cruzada desde las laterales izquierdas, mientras que en el medio de ellas aparece una nena mirando a la cámara).

CB: Y al parecer estabas en el momento preciso, en el lugar justo...

JPF: Sí y es una foto que se da luego que yo me había ubicado dentro del corralón donde entran los fieles a saludar esa imagen en el santuario y sabía que en algún momento podía 
darse esa imagen. Es lo que te decía antes, uno se va ganando los lugares. Y esto habrá sido una ráfaga de cinco o seis fotos que disparé en ese momento. Trabajé a baja velocidad también. Desde la composición, digo que estaba lograda porque buscaba las diagonales que en este caso se da con el cruce de brazos. Eso porque las diagonales presentadas de este modo siempre le otorgan equilibrio a la foto. Por eso en una primera instancia aún sin el rostro de la nenita, técnicamente era una buena foto con el punto fuerte de interés en la imagen del Gauchito. Pero de repente, aparece la cabeza de la nenita entre las manos, y mira y la luz la ilumina de modo tenue pero suficiente para que resalte y fue un instante que define y cambia totalmente la imagen.

CB: Claro, se define allí el segundo punto de interés principal casi en el centro. ¿Y cómo se da esa mirada de la nenita? ¿Buscabas ser mirado o que mire a la cámara? ¿A qué distancia es la toma?

JPF: Esto habrá sido a un metro, un metro veinte del objetivo. Y desde una óptica que te lleva a estar ahí cara a cara. En esa distancia, hay sin lugar a dudas una percepción corporal de uno y del fotografiado que determina la foto. En este caso no digo que mi movimiento haya hecho que la nenita mire, pero percibe que estaba ahí muy cerca, no sé si esperando, porque todo fue muy rápido, pero ella va hacia el Gauchito y me ve allí y mira y me permite captar un momento de intimidad muy particular, del acto religioso y de nuestras miradas. En general el fotografiado puede mirar al fotógrafo y vos justo no disparás porque no estabas preparado o porque no crees que eso sirva para la foto, en este caso se dan las dos cosas de manera contraria, positiva.

CB: Me gusta desarrollar esa idea de la percepción corporal como determinante de la foto de corta distancia. ¿Algo de esto y eso de decidir captar o no la mirada a la cámara influye en Devoto, el retrato de este gaucho vestido casi a imagen y semejanza de la iconografía del Gaucho Gil que más conocemos?

JPF: Sí totalmente. Pero es diferente a la de la nenita, ahí fue todo más espontáneo, sobre todo la mirada y en este caso se construyó como más calculado y de forma colaborativa con la pose del fotografiado. Acá él percibe mi cercanía, observa que yo voy buscando el encuadre y en ese intercambio de percepción parece que el entendió que me ponía de costado y no de frente y de algún modo, me habilita. Parecería que implícitamente me decía 'hacé y buscá lo que necesites'. Incluso pude trabajar el triángulo de luz en el pómulo del rostro que es un recurso del retrato de estudio y en ese contexto muy ambiciosamente buscado se logra por la predisposición del fotografiado.

CB: El punto de interés derecho es su rostro emocionado y su mirada hacia un punto de fuga izquierdo y el otro punto de interés en la izquierda es la imagen de la bandera con la iconografía del Gaucho Gil donde recortaste en el cuello y decidiste no conservar la cabeza dentro de la toma ¿hay una intención conceptual en esa composición.

JPF: Primero la idea era que salga él y la bandera completa. Hay unas fotos previas así, pero después me di cuenta que no era lo que funcionaba más. Me dio la impresión que el hecho de que falte la cabeza del Gauchito Gil de la bandera iba hacer que el espectador busque completar la información en el rostro del devoto. Es otro recurso también que se suele usar y en este caso funciona más aún por cómo él estaba vestido, es otro Gaucho Gil prácticamente.

CB: ¿Verlo ahí, vestido así, impacta no?

JPF: Sí indudablemente me atrapó la imagen por el parecido, su predisposición. Y a muchos fotógrafos les pasa, él está en fotos de muchos por eso. 
CB: Es uno de los casos de la gente que va lookeada que decía Guille. Pero además en esta imagen como en otras de 2008 lográs el dramatismo buscado. Es hasta melodramático. ¿Son éste tipo de imágenes o los de la multitud más tradicional lo que más te publican?

JPF: Lo que más se publica es la masividad y el comercio. El retrato si no va acompañado de un testimonio generalmente no, pero las imágenes como ésta de gran expresividad, o estas otras donde vos mostrás acción con alguna referencia de la festividad tienen mucha demanda actualmente por el impacto que producen.

CB: Una última pregunta antes de terminar por hoy. En enero de 2013 no fuiste al Gauchito. ¿Fue intencional o sólo no pudiste ir?

JPF: Un poco de las dos cosas pero creo que quiero parar para establecer una distancia con lo que vengo haciendo y volver con un punto de vista distinto. El último año la idea fue no estar tanto en el centro de los rituales o el santuario sino más bien indagar en los alrededores. Ahora quiero buscar una historia, tal vez seguir a un devoto en particular, hacer algo más documental. ¡Veremos! (Ríe).

Buenos Aires, 5/07/2013

CB: Guille, en el café el año pasado dijiste que volver a las festividades te hace mirar de otro modo. ¿Podés hacer el intento de repasar las diferentes formas de mirar que puedas identificar de tus producciones por ejemplo del Gaucho Gil que es lo que más hiciste?

GR: A ver... es difícil pero si volvemos a ver las fotos esto tiene que ver nuevamente con los motivos que llevaban a que vos estés ahí. En 2004 porque el objetivo fue filmar un documental nos dimos un buen tiempo de pre producción en terreno y pudimos entrar a la fiesta, conocer la historia, el lugar pero también el backstage que es muy importante porque te permite conectarte con la gente y con el ambiente. Y si volvés varias veces, en un momento si bien vos sos foráneo y tal vez no compartís las creencias, pero llegás a conocer y ser incorporado de una forma diferente a lo que allí sucede.

CB: ¿Se construye una mirada más cercana?

GR: Sí creo que sí, de alguna manera pasas a formar parte de esa fiesta.

CB: De hecho, vos mismo decías antes que en el Gauchito particularmente los medios, los fotógrafos, forman parte de esa fiesta porque la mayoría va predispuesta a mostrarse y a contar su historia

GR: Sí además y creo eso se da porque los medios son los que de alguna manera los ayudan a mostrar al país esa fiesta, le dan difusión. Y todo eso básicamente es producto de la imagen, porque lo que es fuerte del Gauchito y lo que impacta, lo que hace que el espectador diga ¡Uh mirá eso! y es la primera vía de acceso a la leyenda, las creencias y el crecimiento del fenómeno, es la imagen. Y hoy ya no hablamos sólo de imágenes en los medios tradicionales, hablamos de facebook, de youtube, o las redes de páginas web o blogs de los santuarios en todo el país, etc.

CB: Algo de eso señalan Alejandro Frigerio y también Gabriela Saidón con quien compartimos en Mercedes en 2011 ite acordás?. Pero vuelvo a la pregunta inicial 
¿Cómo vemos las marcas de esa mirada más cercana y producto de estadías más extensas en las fotos?

GR: Si miramos las fotos, en una primera instancia nos pasa lo mismo a todos, vas por la captura de la multitud porque es la foto de tapa que te piden, y por la imagen más impactante, más dramática porque es un elemento presente en la fiesta por los colores, por los gestos, por los movimientos que no podés desaprovechar. Entre esas dos miradas pasaba mi producción de fotografia para el diario hasta 2008 , pero a la vez ya iba ensayando composiciones que tenían que ver con intereses particulares donde exploraba la intimidad de las miradas, el paisaje, los contrastes entre la variada simbología que provienen de diversos orígenes y creencias, lo que sucede en las afueras del centro del festejo.

CB: ¿Hay un alejamiento de esa captura de las imágenes de alto impacto, más dramáticas? ¿Y cómo se pone a circular estas imágenes si no es lo que se demanda desde los medios?

GR: Sí porque el sentimiento o las situaciones intensas que genera este tipo de devociones no necesariamente se tiene que expresar explícitamente en unos rostros cubiertos de llantos o cuerpos muy contorsionados sobre el santo, sino también a través de capturas más sutiles que tienen que ver con atmósfera u otras cosas. Y son búsquedas que por ahí no tienen lugar en los diarios pero hoy en día hay otros espacios que tienen que ver con internet o con espacios de exposición, entre otros.

CB: ¿Y cómo se hace para no perder la capacidad de sorpresa después de ir tantos años, conocer el lugar, los personajes y hasta momentos poder guardarte un lugar determinado porque sabés lo que viene y esperás fotografiarlo?

GR: Sin la capacidad de sorpresa nuestro trabajo se había acabado hace rato. Y además uno no puede controlar todo, las cosas suceden y la fotografía por eso es efímera, más allá de lo que vos puedas controlar, calcular, cada instante es diferente a otro y la captura es algo hasta mágico. Y eso tiene que ver con buscar no solo lo que ves y lo que tenés en mente sino lo que no ves y lo que sentís cuando algo que está frente a la cámara interpela otros sentidos.

CB: Juan me hablaba de la percepción corporal...

GR: Sí porque la mirada incluye todos los sentidos no es sólo la vista y los intereses personales, no sólo de las empresas para las cuales uno trabaja. 